University of South Florida

DIGITAL COMMONS

@ UNIVERSITY OF SOUTH FLORIDA
Digital Commons @ University of

South Florida

Integrative Biology

Integrative Biology

$11-1927$

\title{
Echinoids of the Indian Museum at Calcutta. III. Regular \\ Echinoids: A Translation of Échinides du Musée indien à Calcutta. \\ III. Echinides réguliers
}

René Koehler

John Lawrence

University of South Florida, lawr@usf.edu

Follow this and additional works at: https://digitalcommons.usf.edu/bin_books

\section{Recommended Citation}

Koehler, R. (2020). Echinoids of the Indian Museum at Calcutta. III. Regular Echinoids: A Translation of Échinides du Musée indien à Calcutta. III. Echinides réguliers (J. M. Lawrence, Trans.). Herizos Press, Tampa.

This Book is brought to you for free and open access by the Integrative Biology at Digital Commons @ University of South Florida. It has been accepted for inclusion in Integrative Biology Books by an authorized administrator of Digital Commons @ University of South Florida. For more information, please contact digitalcommons@usf.edu. 


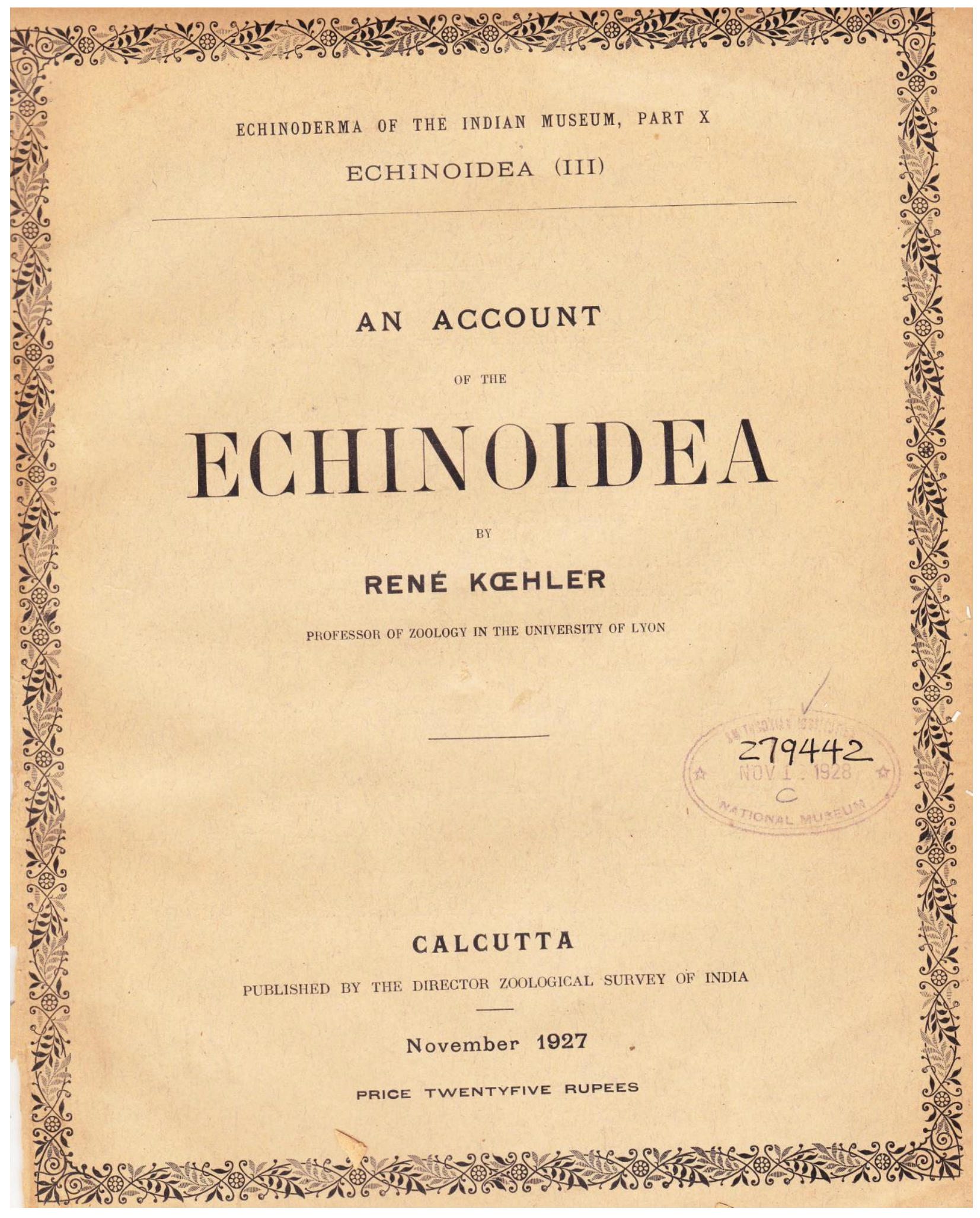




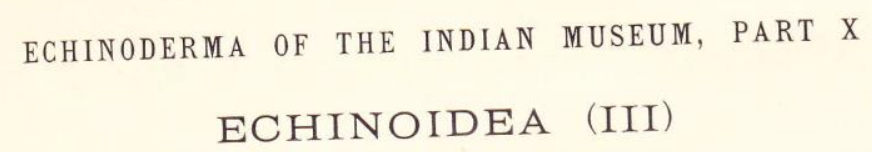

\section{AN ACCOUNT}

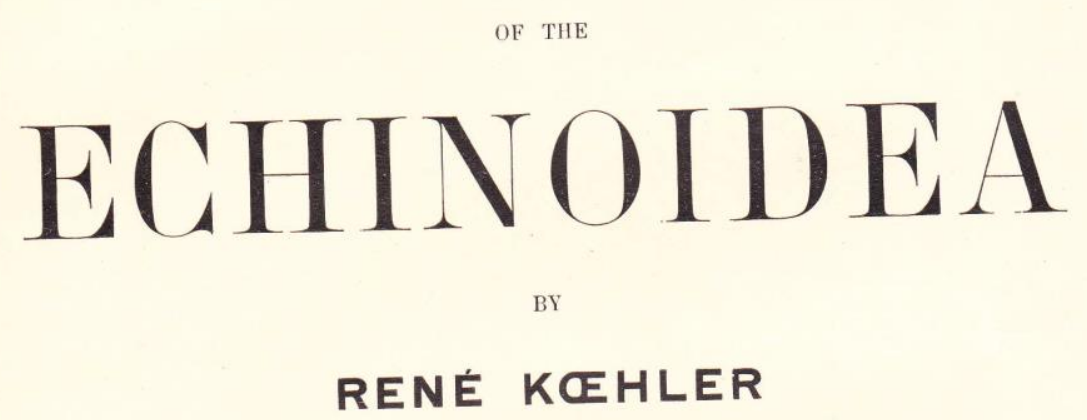

PROFESSOR OF ZOOLOGY IN THE UNIVERSITY OF LYON

\section{CALCUTTA}

PUBLISHED BY THE DIREGTOR ZOOLOGICAL SURVEY OF INDIA

November 1927

PRICE TWENTYFIVE RUPEES 


\section{ECHINIDES}

DU

\section{MUSÉ IN D I E N \\ A CAlCutta}

PAR

RENÉ KEHLER

CORRESPONDANT DE L'INSTITUT

PROFESSEUR DE ZOOLOGIE A L'UNIVERSITÉ DE LYON

III. Échinides Réguliers

OAIOUTTA

November 1927 
Koehler, R. (2020). Echinoids of the Indian Museum at Calcutta. III. Regular Echinoids: A Translation of Échinides du Musée indien à Calcutta. III. Echinides réguliers. (J. M. Lawrence, Trans.). Herizos Press, Tampa.

(C) John M. Lawrence. Herizos Press, Tampa, Florida. 
Translator's notes.

This memoir is the last of Kœhler's trilogy of the echinoids of the Indian Museum at Calcutta.

The first two are:

Kœhler, R. 1914. Échinides du Musée indien à Calcutta. I. Spatangidés.

Kœhler, R. 1922. Échinides du Musée indien à Calcutta. II. Clypeastridés et Cassidulidés.

They are substantial works that contribute greatly to the knowledge of the morphology, taxonomy, and zoogeography of echinoids.

Kœhler suggested there was a delay in publishing this memoir on Regular Echinoids. He stated (page 137) "I had proposed to describe in detail these five St. indica in the present memoir what had been written in 1922. But as the publication of this memoir was delayed and I believed it would continue to be delayed, I was led to study these five specimens in the memoir that I devoted to "Anomales, Irrégularités et Déformations du test chez les Échinides" (Annales de l'Institut Océanographique, nouvelle série, Tome I, p. 159-480, avec atlas de 32 planches, 1924).” His memoir on Regular Echinoids was published in 1927.

I did not take the responsibility of correcting apparent misspellings or typographical errors

I thank Michel Jangoux for his help with some difficult words and passages.

I thank David Pawson for arranging the loan of a copy of this memoir from the Smithsonian Institution. 


\title{
ECHINOIDS
}

OF THE

\section{INDIAN MUSEUM AT CALCUTTA}

\author{
III. Regular Echinoids
}

This memoir that I publish today is the last that is concerned with the description of the echinoids of the Indian Museum and at the same time, it ends the study of the echinoderms that Superintendent Alcock has kindly confided to me previously. It refers to the regular echinoids.

Among the specimens that have been delivered, some have already been describe by Alcock, Anderson and Wood-Mason. They are notably Dorocidaris tiara and Stereocidaris (Cidaris) Alcocki. I have naturally preserved these two names. The latter species has been transferred to the genus Stereocidaris and I have completed the description of it when necessary, notably concerning the pedicellariae. Several specimens that were sent to me have prior determinations and have names of known species for the most part. In these determinations, some were correct, others were incorrect. It is thus that some Phormosoma indicum were labeled Ph. bursarium. Stereocidaris Alcocki and indica and even other cidaroids had indifferently the names of Cidaris indica, Lorioli, etc. There was no need to retain these hasty determinations. Other specimens attributed to the genera Cidaris, Astropyga, Salmacis, Diadema, Temnopleurus, etc. had likewise wrong determinations.

It appears to me certain that the collection that has been sent to me does not contain all the regular echinoids collected by the INVESTIGATOR in the seas of India. I have been able to see that some specimens mentioned by Anderson or by Alsock and Wood-Mason, in their notes of 1891 and 1894, are not there. This is the case for example for Cidaris Alcocki, Pygmaocidaris prionigera, several Stomopneute variolaris, etc.

Whatever it is, I have recognized in the collection that I received, fifty species or varieties of regular echinoids, among which thirty-six were already known and fourteen are new. Regarding these latter, two form types of new genera as well.

Here is the enumeration of these species arranged by families: 
CIDARIDAE

Eucidaris metularia (Lamarck).

Histocidaris denticulata nov. sp.

Dorocidaris tiara Anderson.

Dorocidaris Lorioli nov. sp.

Acanthocidaris maculicolllis (Meijere).

Stereocidaris indica Döderlein.

Stereocidaris Alcocki (Anderson).

Prioncidaris baculosa (Lamarck).

Pronocidaris baculosa var. annulifera (Lamarck).

Prionocidaris brevicollis (Meijere).

Stylocidaris bracteata var. albidens H. L. Clark.

\section{ECHINOTHURIDAE}

Hygrosoma luculentum (Agassiz).

Phormosoma indicum Döderlein.

Phormosoma verticillatum Mortensen.

Areosoma coriaceum var. indicum nov. var.

Sperosoma biseratum Döderlein.

Sperosoma armatum nov. sp.

\section{DIADEMATIDAE.}

Diadema saxatile (Linné).

Echinothrix diadema Linné.

Echinothrix calamaris (Pallas).

Chotodiadema granulatum Mortensen.

Astropyga radiata Leske.

Centrostephanus nitidus nov. sp.

\section{ASPIDODIADEMATIDAE}

Aspidodiadema annulatum nov. sp.

ARBACIADAE.

Pygmaeocidaris prionigera (Agassiz).

Colopleurus vittatus nov. sp.

\section{SALENIDAE.}

Salenia sculpta nov. sp. 
PEDINIDAE.

Cœnopedina depressa nov. sp.

TEMNOPLEURIDAE.

Temnopleurus toreumaticus Klein.

Salmacis bicolor Agassiz.

Salmacis rarispina Agassiz.

Salmacis virgulata Agassiz.

Salmacis Dussumieri Agassiz.

Salmacis roseo-viridis nov. ap.

Mespilia globulus (Linné).

Prionechinus Agassizii (Wood-Mason and Alcock).

Paraatrema Döderleini (Mortensen).

Temnotrema scilla (Mazetti).

Temnotrema siamense (Mortensen).

Trigonocidaris versicolor nov. sp.

Printechinus impressus nov. gen. nov. sp.

STOMOPNEUSTIDAE.

Stomopneustes variolaris Lamarck.

ECHINIDAE.

Toxopneustes pileolus (Lamarck).

Tripneustes gratilla Linné.

Prymnechinus proctalis nov. gen. nov. sp.

Gymnechinus megaloplax H. L. Clark.

Gymnechinus pallidus nov. sp

STRONGYLOCENTROTIDAE.

Echinostrephus molaris (Blainville).

Pseudoboletia indiana (Michelini).

ECHINOMETRIDAE.

Echinometra Mathoei (Blainville)

The species or varieties whose name is printed in bold are new.

As I have done in the previous volumes on the echinoderms of the Indian Museum, I have believed it necessary to take advantage of the opportunity that it offered me in studying some regular urchins to describe two species that do not belong to this Museum but that come 
from the Indian Ocean. One of these species is a Lytechinus from Ceylon that was sent to me by $M$. Thiéry and that is new. I give it the name of $L$. Thieryi. The other is a very poorly known Echinometra, E. michelini, to which I have been able to refer some specimens. It appeared interesting to me to study here and compare it to another species of the Indian Ocean, notably E. Mathoi.

I must make a remark on the subject of the collection that has been sent to me. Most of the specimens that I have received have arrived in excellent condition. However, despite all the care in packing, several jars were broken en route. The alcohol evaporated and the specimens were completely dried. This happened mainly to the large jars containing Stomoponeustes variolaris, Hygrosoma luculentum and Sperosoma. The misfortune was not great in concerning the Stomopneustes, but it was not the same for the echinothuroids. These were not only dried but very strongly deformed. Several were completely folded on each other. It has been very difficult, if not impossible to unfold them to rectify the form. Some of them were absolutely unusable. 


\section{Cidaridae}

\section{Eucidaris metularia (Lamarck)}

See for the bibliography:

Cidaris metularia. Meijere, 1904, p. 7.

Cidaris metularia. A. Agasszi and H. L. Clark, 1907, p. 5.

Eucidaris metularia. Mortensen, 1910 a, p. 54.

Eucidaris metularia. Döderlein, 1911, p. 239.

Eucidaris metularia.. H. L. Clark, 1923, p. 370.

Andaman Islands. - 36 fathoms. — Ten specimens.

Andaman Islands. - Tidal. - One specimen.

Invisible Bank. - 16-41 fms. - Two specimens.

Station 204. - $6^{\circ} 01^{\prime}$ N.; $81^{\circ} 16^{\prime} \mathrm{E}-34 \mathrm{fms}$. - Three specimens.

The diameter of the test varies between 13 and $11 \mathrm{~mm}$.

This species is well known and is fairly frequently found in collections. I have nothing to add to the information that the authors have given about it. We shall find a description and good figures of the pedicellariae in the memoire of Agassiz and Clark 1902 cited above.

E. metularia is very widespread in nearly all the littoral Indo-Pacific domain. It is particularly common on the east coast of Africa from the Cape to the entrance of the Red Sea and in the African islands: Madagascar, Mauritius, Reunion, etc. It is also known in the seas of China, to the Philippines and to the Marianas well as the Ryukyus, but it has not been found in Japan. Finally, it is found in the Bay of Bengal, to the islands of Sunda to New Guinea, to the Solomon Islands, etc., but it does not go down to the coasts of Australia. We know it finally at the Fiji Islands, on one hand, and Hawaii, on the other.

Histocidaris denticulata nov. sp.

(Pl. I, fig. 1, 2, 3, 6 and 7; Pl. II, fig. 1; Pl. XXIII, fig. 1)

Histocidaris elegans. Döderlein, 1907, p. 107, p. 117; pl. XIII, fig. 1 to 4 and pl. XL, fig. 3.

Bay of Bengal. - 220 -240 fms. One specimen whose apical system is missing. Diameter of test $54 \mathrm{~mm}$.

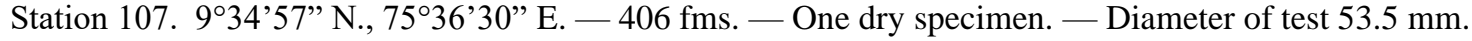

In their memoir of 1907 on the CIDARID $Æ$, Agassiz and Clark have, in citing Porocidaris elegans, remarked that the specimens captured by the VALDIVIA, and to which Döderlein had applied the specific name of elegans, differs from the latter species not only by their remarkable brilliant color, but by the small size of the apical system, the periproct and the peristome, by the very spiny primary spines and finally by the large number of coronal plates. They suggested it was very probably a new species. 
In the key these authors provided, p. 225 of their memoir, they place Porocidaris elegans in the group of species that is characterized thusly: "Abactinal system $0.4-0.5 \mathrm{~h}$. d., primaries stout (thickness of large ones 3-6 \% of length), finely sharply thorny." They also remark that the denticulations of the spines are not always perceptible to the naked eye, but that we recognize them easily by touch.

Döderlein has published a very complete description of the specimens collected by the VALDIVIA and he has reproduced good photographs of some of them. Now it is necessary to note that before the memoir of Döderlein, we did not have, in brief, a very complete description of $P$. elegans. In fact, A. Agassiz, who had established the species, had not given, strictly speaking, a detailed description of it in the few lines that he devoted to it in 1879 (Proced. americ. Acad. Vol. XIV, p. 198) and in the Reports of the CHALLENGER in 1881, p. 40. He compares the new species especially to $P$. purpurata, saying that it differs from it by the characters of the spines, by the structure of the apical system, by the wide row of secondary tubercles surrounding the scrobicular circles of the primary spines. He adds that the middle of the interambulacral zones has larger secondary tubercles, leaving a bare space between secondary spines, or is simply covered with sparse small miliary tubercles. The primary spines are more uniform in $P$. elegans than in $P$. purpurata and their length often is three times the diameter of the test. These spines are cylindrical, slightly tapering, with very fine longitudinal stripes and small denticulations. The peristome is small. Most of the description of Agassiz is devoted to the crenulation of the primary tubercles in Porocidaris and in various other genera of CIDARIDÆ. Agassiz gives no information about the apical system. He gives no information about the dimensions of either the specimens themselves, or of different parts of the test. As the figures he reproduces in Pl. III, fig. 1, 2 and 3 are of natural size, we can, in measuring them, be assured that in an individual whose test diameter is $40 \mathrm{~mm}$, the periproct is 28 to $28.5 \mathrm{~mm}$ and the peristome, $18 \mathrm{~mm}$. In the individual represented in fig. 1 , the test has a diameter of 28 to $29 \mathrm{~mm}$ and the primary spines can reach $75 \mathrm{~mm}$ in length. The respective diameters of the apical system and the peristome are thus 70 and $45 \%$ of the diameter of the test.

Mortensen has had the opportunity to study the P. elegans of the CHALLENGER, but he confined himself to examining the pedicellariae about which he gives very important information. Meijere has likewise studied, under the name of $P$. elegans, specimens collected by the SIBOGA from the archipelago of Sunda. The largest individual is $85 \mathrm{~mm}$ in diameter. The primary spines can reach $140 \mathrm{~mm}$ in length. They are very thick, a little enlarged at the end, striated longitudinally and having small denticulations on the sides. In other individuals, the denticulations are so fine that one cannot see them with the naked eye. Meijere unfortunately does not give any information about either the apical system or the peristome.

The two specimens collected by the INVESTIGATOR are of large size. The first, that comes from station 197, is in good condition but dried. Its diameter if $55 \mathrm{~mm}$ and its height is 47 . I have called it A. That from the Bay of Bengal (B) is in alcohol. Its diameter is very near that of the preceding individual $(58.5 \mathrm{~mm})$, but the test is a little less high. It is only $43.5 \mathrm{~mm}$. The apical system is entirely missing.

In both individuals, the dimensions of the apical system and the peristome are nearly the same and do not exceed $20 \mathrm{~mm}$ for the first and 15.5 to $16 \mathrm{~mm}$ for the second. The diameter of the periproct is $9 \mathrm{~mm}$ in individual $\mathrm{A}$. The respective diameters of the apical system and the peristome are thus 38 and $29 \%$ of the diameter of the test. These systems are thus notably smaller than in Histocidaris elegans, the dimensions being greater in the latter according to the figures of Agassiz. 
I shall describe the species mainly after specimen A.

The contour of the test is clearly pentagonal. The dorsal and ventral surfaces are flat. The apical system does not perfectly conform to that represented in the photograph given by Döderlein in 1907, pl. XIII, fig. 1. The genital plates are in fact longer and the ocellar plates have a more triangular form than in the specimen of the VALDIVIDIA. The first are large, longer than wide. Their length varies between 7 and $8 \mathrm{~mm}$. They are pentagonal with two lateral borders slightly curved inward. Their width at the base is $6 \mathrm{~mm}$ and at their middle is $5.5 \mathrm{~mm}$. They each have a very large opening whose diameter is $3 \mathrm{~mm}$ and whose external border is approximately $1 \mathrm{~mm}$ from the distal corner of the plate. The madreporite is a littler larger than the others. Its length is $9 \mathrm{~mm}$. The ocellar plates are triangular, wider than long. They measure approximately 7 by $4 \mathrm{~mm}$. They have a proximal right angle on plates 1, 5 and 4. This angle is obtuse on plates 2 and 3 that are adjacent to the madreporite. The opening is elongated.

The periproct is regularly pentagonal with the sides sightly concave. The side contiguous with the madreporite especially is strongly concave. It measures 8 to $8.5 \mathrm{~mm}$ in width. It has an external row of large plates whose internal border is round, smaller toward the side that touches the madreporite. Inside, it is covered with very much smaller plates that become extremely reduced toward the anus.

The remarkably small peristome is not covered by clearly imbricated plates, as Agassiz has represented them in H. elegans, but by rows, each containing about a half dozen of very enlarged plates, contiguous with each other by their large borders and having toward their internal border a regular row of small tubercles.

The ambulacral zones are nearly $7 \mathrm{~mm}$ in width at the ambitus. They are sinuous and completely flat. The successive pairs of the pores are very near each other. The external pores are transversely widened. The internals are smaller and irregularly circular. The two pores of each pair are separated by a small ridge. The width of the interporiferous zone nearly equals that of the poriferous zone. Each side has a completely regular row of very apparent small secondary tubercles separated from each other by an interval smaller than the diameter of the tubercles. The secondary tubercles are very near the external pores. They leave in the middle of the zone a space where there are scattered rare miliary tubercles. This row of tubercles is thus much more regular than in the Histocidaris studied and represented by Döderlein of the specimen of the VALDIVIA, in which the secondary tubercles are separated by from each other by a fairly large interval in which we often see a miliary tubercle. This is not the case here. The only miliary tubercles that we see are found inside the row of secondary tubercles.

We can see at the ambitus eleven pairs of pores corresponding generally to an interambulacral plate as Döderlein has said.

The interambulacral zones measure 21 and $22 \mathrm{~mm}$ in width at the ambitus. They are remarkable for the number of plates that they enclose. Each row has in fact eleven to twelve plates whose size increases progressively from the first to the seventh that is found at the ambitus. The first three plates are very small. The primary tubercles are rather small. They are strongly and deeply crenulated except the ventral last three that are very small. The scrobicular circles are confluent on the ventral surface and at the ambitus. We usually do not see secondary tubercles between successive circles, except on the dorsal surface. These characters conform with those that Döderlein indicated.

The primary spines become very long, but only the small ventral spines are preserved in their entirety. These spines ae thin, delicate and very fragile. Their characters are those indicated by Döderlein. They are shown clearly in the various photographs in pl. XIII this author has published. 
The denticulations of the spines of the dorsal and lateral surfaces of the test are more or less developed and very apparent. They are fine and very pointed, stronger and nearer each other on the lateral and ventral spines than on the dorsals. The spines of the first three tubercles of each row on the ventral surface are flat, often curved, with two lateral rows of very strong denticulations, as we can recognize my photographs and those of Döderlein. There is no need to emphasize these characters.

I can say nothing about the characters of the spines in the young. According to Döderlein, these spines appear smooth because their asperities are extremely indistinct. As the individual represented by this author in pl. XIII, fig. 3, and in which the diameter of the test is $13 \mathrm{~mm}$, with spines completely smooth and comparatively longer than in the adult, the length exceeds five times the diameter of the test. Also, the appearance of this individual is quite different from that of large specimens.

The secondary spines of the interambulacral zones are very wide, flat, rounded at the end. The ambulacral spines are very much thinner. They are, however, a little flat and their end is blunt.

The characters of the pedicellariae have been indicated by Döderlein. I find, like this author, only tridactyl pedicellariae of very different sizes, sometimes very long and very large. The length of the head can reach $5 \mathrm{~mm}$. The smallest is only 0.2 to 0.3 . I reproduce here photographs of some of these pedicellariae (Pl. XXIII, fig. 4). I have never encountered didactyl pedicellariae.

The color of the specimens is simply gray, a little darker on the dry specimens, without the least trace of the red color preserved in the specimens of the VALDIVIA.

SIMILARITIES AND DIFFERENCES. - Despite some differences in the form of the genital and ocular plates and the arrangement of secondary tubercles in the ambulacral zones, I think the two specimens of the INVESTIGATOR belong to the same species as those of the VALDIVIA described by Döderlein. I do not completely agree with the point of view of H. L. Clark, who considers the species is different from Histocidaris elegans. The difference in the characters of the spines with denticulation in the individuals of the VALDIVIA and the INVESTIGATOR would not in itself justify a specific separation. The creation of a simple variety would be sufficient to recall this particularity. But the characters of the relatively small apical system, and especially the comparatively very reduced peristome appear to me to constitute fairly important characters making necessary the creation of a new species that I propose to call denticulata because of the characters of the spines.

If all the specimens collected by the VALDIVIA have the characters of the specimen from station 194 (Nias Island) represented by Döderlein, H. denticulatus is found not only in the Bay of Bengal and toward the coast of Sumatra, but also on the east coast of Africa.

It is impossible to decide from the information given by Meijere if the specimens collected by the SIBOGA in the different islands of Sunda are Histocidaris elegans as indicated by the author, or if they are $H$. denticulata. To decide this question, it would be necessary to examine the specimens of the SIBOGA.

\section{Dorocidaris tiara Anderson}

(Pl. I, fig. 4 and 5; Pl. II, fig. 2; Pl. III, fig. 1 and 6; Pl. IV, fig. 1, 2, 4 to 9; Pl. V, fig. 1, 5 and 6; Pl. XXIII, fig. 2) 
Dorocidaris tiara Anderson, 1894, p. 1888.

Dorocidaris tiara Alcock and Anderson, 1895, fig. 2 and 3.

Dorocidaris tiara H. L. Clark, 1907, p. 202.

Stylocidaris tiara Mortenson. 1910, p. 54.

Dorocidaris tiara. Lambert and Thiéry, 1910, p. 149.

S. coast of Ceylon (Colombo). - 142-140 fms. - Numerous specimens.

Station 204. - 6 ${ }^{\circ} 50^{\prime} 20^{\prime} \mathrm{N} ; 79^{\circ} 36^{\prime} 20^{\prime}$ E. $-180-217 \mathrm{fms}$. Several specimens of which two are fairly large size.

Station 248. - 224-284 fms. Several specimens.

Andaman Sea. - $120 \mathrm{fms}$. - Two specimens; one of them is $30 \mathrm{~mm}$ in diameter.

It is necessary to note that since 1894, the period in which Anderson published the description of D. tiara, this species has never been studied. The authors I am going to refer to have been content to simply cite the species. Mortensen, in 1903 (Ingolf Echinoidea, p. 173), thought that $D$. tiara is synonymous with Stephanocidaris bracteta. But this synonymy could not be maintained because, among other things, the characters of the pedicellariae that I shall indicate later. I did not think I should include St. baracteata, which Agassiz and Clark have placed in the genus Dorocidaris in 1907, among the synonyms of D. tiara. Moreover, this synonymy was abandoned by Mortensen who, in his memoir of 1910, separated the two species tiara and bracteata (that he referred to the genus Stylocidaris).

The original description of Anderson was based on numerous specimens collected south of Ceylon at depths varying from 142 to $400 \mathrm{fms}$. I have had in my hands a more or less large number of these specimens. Approximately three hundred were sent to me. Some specimens from other stations are also in the collection that I have received. I have reported them above.

I recall that the description published in 1894 by Anderson in the Journal of the Asiatic Society of Bengal, vol. LXIII, part. II, no. 3, p. 188 was not accompanied by figures, but Alcock and Anderson have given, in the Illustrations of the Zoology of the R. I. M. S. Investigator, part. II, vol. $\mathrm{V}$, fig. 2 and $2 a$, two photographs representing a view of the dorsal surface and a lateral view of a large specimen of this species.

The description of Anderson is very complete, except in regard to the pedicellariae of which the author does not speak. But the characteristics of the test and spines are given in the most exact way. Thanks to this description and to the two figures in the Illustrations, the species is very easy to recognize. Except for the pedicellariae that I shall study later, I have only some secondary remarks to add to the excellent description of Anderson. But as this description is found in a publication not widely distributed, it seemed to me to be useful to give here the translation that I shall make following the description of the pedicellariae and some remarks that I have added.

The test of D. tiara varies greatly with age. In small specimens, it is sunken on both the dorsal and ventral surfaces. But in the large individuals, while the ventral surface remains flat, the dorsal surface becomes, to the contrary, elevated and sometimes conical, but with the apical system truncated. The circumference of the test at the ambitus has the form of a pentagon with round corners.

The apical system is of moderate size. It is approximately two-thirds of the diameter of the test and is pentagonal. The genital and ocellar plates form together a flat area, slightly sunken, in which the periproct forms a round eminence.

The genital plates are large and triangular, with a round point and sides that are in contact with the slightly concave ocellar plates. The madreporite is a little larger than the others. All these plates 
are separate, some periproctal plates send an extension, sometimes narrow, sometimes wide between the successive genital plates. The genital pores are large and circular. They are located in the external third of the plate. They are in part blocked by a thin membrane. The genital plates, except toward the borders that are smooth, have their surface covered by large granule that tend to be arranged in two groups. One forms a couple of concentric circles around the genital pore, the internal formed of smaller granules than the external circle. The other group is localized at the base of the plates and is found inside a curved line of granules that extends between the internal corners of the plates. The madreporte is entirely covered by granules slightly smaller than those of the other plates.

The ocellar plates are largely cordiform. They are covered, except toward the borders, with large granules. The pore, which has the form of a transverse slit, is located a short distance from their external border.

The plates of the periproct form together a pentagon that often sends extensions between the genital plates to come into contact with the ocellar plates. The plates of the external row are large, polygonal and number nine to eleven. They have a central group of large granules. The interior rows are similar to these plates but smaller.

The ambulacral zones are wide, nearly straight and flat transversely. They can rise in fairly distinct prominences when they reach the apical system. The poriferous zone is very slightly narrower than the interporiferous zone. It is separated from the interambulacral zone by a slight ridge. The pores are in no way conjugated. There is only a very slight ledge to separate the successive pore pairs. These pores are large and oval. The interporiferous area has four rows of granules. The marginal granules are much larger than the internals. We encounter in addition between these rows, granules in smaller number, regularly arranged. On each side of the median suture is a very narrow space.

The interambulacral areas are approximately two and a half times wider than the ambulacral areas. The plates are less numerous. They number seven to eight. They are elongated longitudinally on the dorsal surface and transversely on the ventral surface. At the ambitus, they are nearly as long as wide. They are separated from each other by shallow sutures, longitudinal and transversal. Each plate has a small, glassy and perforated mamelon, supported by a slight conical prominence, surrounded by a scrobicular circle. The first and second interambulacral plates coming from the apical system each has an elongated eminence elongated longitudinally with small, very rudimentary mamelons. The first plate never has spines. The second has one very rarely. When we look at the test from above, we see only two or three well developed mamelons at the ambitus in each interambulacral zone. Near the ambitus, the scrobiculae form circles. But on the ventral surface, toward the peristome, these scrobicular circles decrease rapidly in size and become more and more elongated transversely. The scrobicular circle is surrounded by a row of secondary tubercles that greatly resemble the primary tubercles in their structure. Outside this row, the plates are covered by a small number of large tubercles and miliary tubercles. The dorsal plates are much more lacking in granules than the plates located at the ambitus and on the ventral surface.

The peristome is round. The peristomial membrane remains flush with the test. It is flat and covered with imbricated scales, each of which has a row of granules having a small spine. The buccal opening is pentagonal. The length of the primary spines at the ambitus equals approximately one and a half times the diameter of the test. These spines are thin. They taper progressively from the base to the end. They have eight sides that are smooth and bare, not granular at all. The spines are solid, but so fragile that on all the specimens it is difficult to find intact ones. The color of these 
spines is pale red, darker at the base. Toward the end, they become pale olive green. On the ventral surface, the primary spines are short, flat and white.

The secondary spines are olive green with a dark median band.

The color of the test is chestnut brown passing to green on the dorsal surface. This green color is very distinct on the apical system.

\begin{tabular}{|c|c|c|c|c|}
\hline & $\mathrm{mm}$ & $\mathrm{mm}$ & $\mathrm{mm}$ & $\mathrm{mm}$ \\
\hline Diamete & 26 & 34 & 35 & 42 \\
\hline 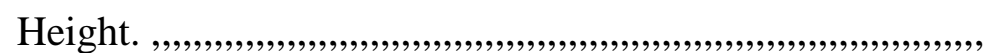 & 19.25 & 24 & 30 & 33.3 \\
\hline Diameter of peristome,, & 10.5 & 12 & 14 & 14.75 \\
\hline 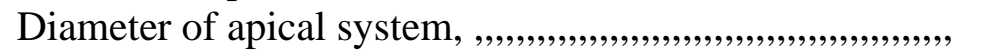 & 12 & 13 & 15.25 & 17 \\
\hline Width of an ambulacral area. ........................... & 4 & 4.75 & 6 & 7 \\
\hline 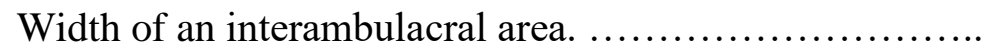 & 11.75 & 13 & 15.5 & 18.5 \\
\hline ength of the spines & 38 & 12 & & \\
\hline Number of coronal plates. & 6 & 7 & 7 & 8 \\
\hline
\end{tabular}

Numerous specimens were dredged at Colombo at a depth of 142-400 fms.

I complete this description of Anderson by the study of the pedicellariae. They belong to two forms, tridactyl and globiferous. In each form, there are large and small pedicellariae.

The large tridactyl pedicellariae are extremely developed. The length of their head reaches and exceeds $1.5 \mathrm{~mm}$. They are fairly widespread over all the test. The valves greatly recall those that are known in other species of Dorocidaris, like those of D. papillata represented by Mortensen in 1903 (pl. IX, fig. 7), but the valves are notably thinner than in this latter species (Pl. XXIII, fig. 2 a). In the intact pedicellariae, the valves remained applied against each for the entire length. The basal part is very short and scarcely represent a sixth of the total length. It is enlarged and nearly as long as wide. It is fairly distinct from the blade. This is not very enlarged at its base and the width decreases progressively to become relatively very narrow. The end, very thin, is a small hook. The widened part of the blade is remarkable for the large, strong denticulations, unequal and irregular that are more or less developed after the valves appear at the beginning of the blade. In general, these large teeth decrease very rapidly in size and are replaced fairly fine teeth that disappear well before the end of the blade. Ordinarily, the first edges of the last third or fourth is completely smooth. However, sometimes the large teeth of the base continue for a fairly large part of the blade. We can, in contrast, find valves on which the teeth at the base remain very little developed and disappear very rapidly, and the edges of the blade are smooth for a large part of their length. The internal surface of the blade has, at least at its base, an irregular and fine network of trabeculae, themselves very irregular. The perforations are extremely small and very regular on the basal part. They are larger and fairly irregular on the blade. The valves of these large tridactyles are fairly fragile. It is fairly difficult to have intact ones in the preparations.

The length of the valves of the small tridactyles varies generally between 0.5 and $0.6 \mathrm{~mm}$. The basal part is comparatively a little wider than in the large ones. It is a little wider than long. Its length is a fourth or a fifth of the total length. The separation of this part and the blade is less indicated than in the large form. This is because the blade is little or not at all widened at its base and remains very narrow its entire length. The edges can remain smooth, but in general they are very finely denticulated on their first fourth or fifth. The end is sometimes round, sometimes fairly pointed. In the latter case, it can recurve into a very small hook (Pl. XXIII, fig. $2 b$ ). 
The head of the large globiferous pedicellaiae has a very variable length. In some, it scarcely exceeds $0.6 \mathrm{~mm}$. In others it nearly reaches $1 \mathrm{~mm}$. The valves are elongated and narrow, notably narrower than in D. papillata. They resemble more those that Agassiz and H. L. Clark have represented in $D$. calacantha. The width at the base is scarcely a fourth of the total length. The valves are finely denticulated on nearly all their length. The opening, of average size, is surmounted by a large tooth. Their structure is the same as that of the large globiferous (fig. $2 c$ ).

D. tiara is a species of relatively small size. In the specimens cited by Anderson, the diameter of the test was respectively 26, 31, 35 and $42 \mathrm{~mm}$. In the specimens sent to me, except for about a half dozen exceptionally developed, the diameter of the test oscillated around $25 \mathrm{~mm}$. Specimens measuring $30 \mathrm{~mm}$ are rare. The largest individual that I have had in my hands, that I reproduce in the photograph in Pl. IV, fig. 4 and 5, has a diameter of $41 \mathrm{~mm}$, the height being $35 \mathrm{~mm}$. The dimensions of most of the individuals being thus fairly small. All have, moreover, their genital openings and consequently are adult. On the other hand, I see in all the specimens that these openings always remain vey small, contrary to the assertion of Anderson.

The length of the spines appears fairly variable. In the specimens of ordinary size, the length of the largest spines can be 30 to $40 \mathrm{~mm}$, and in the specimens of largest size, the length can reach $50 \mathrm{~mm}$. These spines remain fairly thin. Their width does not exceed $2 \mathrm{~mm}$ at the base. The essential character of these spines has been clearly indicated by Anderson. The existence of eight projecting longitudinal sides, but ordinarily rounded, separated by fairly deep channels, is completely constant. These sides attenuate of course, up to the end of the spine. We very rarely encounter spines nearly smooth and on which the traces of these sides are completely effaced. I suppose that such spines have been covered for some time, more or less long, by foreign organisms, sponge, bryozoans, etc., that have prevented the normal development of the sides and that have then disappeared. On the ventral surface, the primary spines, much shorter than the others, have sides less developed and often completely absent. The spines are then completely smooth. Sometimes they are s little flat. As Anderson noted, the sides are "plane elevations, not granular", The surface of the sides is in fact completely smooth, their border is either round or a little angular. But, in principle, the border has not the least trace of denticulations, granules or sinuosities. This structure is completely characteristic of D. tiara. However, I have observed, very rarely it is true, some spines like those that I represent in Pl. III, fig. 6, in which the sides, at first completely smooth at the base, begin to have toward its first third some denticulations, at first very fine, that then develop more or less strongly up to the end of the spine. These denticulations are sometimes round, sometimes conical and a little irregular. But we observe something more in the last third of these spines. Between the regular eight sides, whose free edge is denticulated, we see appear in the channels separating the sides, some small and very fine spines, similar to those that are found on the free border of the spines, so that the terminal part of the spine has a series of parallel rows of granules that number about fifteen. It thus takes a different character than it had in the first half where the eight sides are completely smooth. I emphasize the characters of such spines that form a kind of transition to the spines entirely covered with fine denticulations that we see in some specimens that I consider as belonging to a species distinct from $D$. tiara of which I am going to speak.

As for the color of specimens in alcohol, I observe in them that the test has a rather pale greenish brown, greenish gray or gray color. The spines are gray or very pale brownish gray. But the apical system always has a special color. The periproct and the genital plates are a very distinctive green that separates them clearly from the rest of the paler test. This color is very weak 
or even completely lacking in the ocellar plates that resemble the rest of the test, so that the periproct and genital plates form together a star whose five branches are obtuse.

\section{Dorocidaris Lorioli nov. sp.}

(Pl. III, fig. 2 to 5)

Andaman Sea. - $112 \mathrm{fms}$; - Three specimens.

Without locality. — Two specimens.

I believe it is necessary to consider as belonging to a species distinct from D. tiara, some specimens that differ from the latter nearly only by the character of their spines covered with numerous asperities and that instead have only smooth sides. These individuals have, moreover, been distinguished previously from other specimens in the collection that was sent to me and whose jars had the label: Cidaris Lorioli. It is true that the name Lorioli has been applied to other cidaroids, notably to Stereocarids indica. I shall keep very willingly the name of Lorioli for the individuals, happy to recall the name of the Swiss scholar who has made beautiful works on echinoderms.

I first thought that $D$. Lorioli could be considered only a simple variety of $D$. tiara, from which it differed mainly by the characters of the spines. But my excellent friend, Mortensen, to whom I sent a specimen of the INVESTIGATOR, thought this form differed sufficiently from $D$. tiara to constitute a distinct species. I have very willingly adopted this point of view. Mortensen is even of the opinion that D. Lorioli is nearer Stylocidaris Reini que D. tiara.

I shall indicate in the table below the diameter of the specimens and the dimensions of the spines.

Diameter

Length of the largest spines

Maximum width of the largest spines

\begin{tabular}{|c|c|c|}
\hline \multicolumn{3}{|c|}{$\begin{array}{c}\text { Specimens from } \\
\text { Andaman }\end{array}$} \\
\hline $\mathrm{mm}$ & $\mathrm{mm}$ & $\mathrm{mr}$ \\
\hline 25 & 30 & 33 \\
\hline 40 & 47 & 46 \\
\hline 3 & $2 . .8$ & \\
\hline
\end{tabular}

We see by the numbers above that the specimens can acquire fairly large dimensions and that they exceed the average size that we observe in the typical $D$. tiara. The spines also acquired larger dimensions, not only is their length greater but they become thicker.

Instead of simply having channels with smooth longitudinal ridges, these spines have very distinct and very tight rows arranged in very regular longitudinal rows. Sometimes these asperities are round, but in general they are more or less conical. They are fine and dense, a little unequal and irregular. The longitudinal rows they form are much tighter than the smooth ridges of $D$. tiara. They are at least two times more numerous, i.e., that we can count fifteen to seventeen on the largest spines. I reported above that we can encounter in D. tiara spines on which the longitudinal 
ridges, very distinct and smooth in the first half of the spine, acquire denticulations in the second half, and that in addition we saw in the spaces that separate the ridges. The asperities give the terminal part of the spines of D. tiara a character fairly comparable to that we observe on spines of $D$. Lorioli. However, this arrangement is extremely rare, and the asperities are always much more distinct in D. Lorioli.

By all the other characters, general structure of the test, color and especially the form of the pedicellariae, etc., the individuals that I refer to D. Loriloli conform to the specimens of D. tiara. However, they reach a larger size that most of this species. We can judge by the photographs that I reproduce here (Pl. III, fig. 2 to 5) the exterior characters of D. Lorioli.

As for Stylocidaris Reini, I have not had the opportunity to see specimens of this species, but Mortensen has been able to study them. He has kindly sent me the comparative notes he has made. St. Reini, he tells me, has a lower test because of the flattening of the dorsal surface. The spines of the dorsal surface of the test are shorter, and the ambulacral pores are larger. I shall add that the authors who have described S. Reini, Agassiz and H. L. Clark and Meijere, have always encountered in it large globiferous pedicellariae similar to those of Stylocidaris affinis, while this form of pedicellariae is absolutely lacking in D. Lorioli (as also in D. tiara). It is also the reason

for which I have believed it necessary to maintain the species in the genus Dorociais, as I have done for D. tiara. I must say in this regard that I separate myself in the point of view of Mortensen who wrote me that. despite the absence of large globiferous pedicellariae in the two species tiara and Lorioli, he is of the opinion of placing them in the genus Stylocidaris.

\section{Acanthocidaris maculicollis (Meijere)}

$$
\text { (Pl. V, fig. } 2 \text { and 3; Pl. XXIII, fig. 4) }
$$

Porocidaris maculicollis. Meijere, 1903, p. 4.

Cidaris maculicollis. Meijere, 1904, p. 15; pl. III, fig. 18 and 19; pl. XI, fig. 111 to 116.

Acanthocidaris maculicollis. H. L. Clark, 1907, p. 224.

Eight specimens without any indication of locality.

Three of these individuals are larger than the others that are much smaller. In the first. The diameters vary between 23 and $17 \mathrm{~mm}$. The length of the largest spines is between 66 and $58 \mathrm{~mm}$. In the four other individuals, the diameter of the test varies between 10 and $11.5 \mathrm{~mm}$. The largest spines can reach $30 \mathrm{~mm}$ in length. One of the three largest specimens, in which the test has a diameter of $17 \mathrm{~mm}$, has on its dorsal surface three parasitic prosobranchs. The latter do not have the shell perfectly intact and their generic determination is uncertain. I believe, however, they belong to the genus Mucronalia.

This beautiful cidroid was discovered by the SIBOGA in the Sunda Archipelago. It was described by Meijere who, after having first placed it in the genus Porocidaris, put it in the genus Cidaris. H. L Clark assigned it to its true generic position, placing it in the genus Acanthocidaris, with $A$. hastigera that is especially close to A. curvatispinis.

I have little to add to the description of Meijere. The species appears always to be of small size. The largest individual that this author had in his hands had a diameter of only $18 \mathrm{~mm}$, with spines $55 \mathrm{~mm}$ in length. We see by the numbers given above that two of the specimens of the 
INVESTIGATOR exceed this size. I find on the large primary spines the curious character indicated by Meijere. The collar region is very developed, smooth on the ventral surface whose color is olive green with a median reddish band, while the dorsal surface of this same collar region has reddish dots arranged in a longitudinal series and forming a very elegant ensemble.

Meijere has described two kinds of pedicellariae, globiferous and tridactyles. The globiferous are not very abundant. In those that I observe, the valves have a slightly different form from that indicated by Meijere (Pl. XXIII, fig. $4 \mathrm{~b}$ ). The height is $0.6 \mathrm{~mm}$ and the width is 0.3 while the Hollander author indicated a length of $0.7 \mathrm{~mm}$ and a width of $0.4 \mathrm{~mm}$. This makes the height less than twice the width, while in the figure of Meiijere, that represents fone of the valves (pl. XI, fig. 112), the height is manifestly more than twice the width. The oval opening has on its periphery a series of small, pointed teeth, becoming larger toward the end of the valve.

There is a second kind of pedicellariae seen by Meijere who considered them as small globiferous and that he represented in pl. XI, fig. 113 and 114. The opening of the valves is oval, very elongated and very developed. It is sometimes nearly half the total length of the valve. This opening has edges with fine denticulations. The valves never have any indication of a tooth at its end. This can be simply pointed, or even a little rounded (Pl. SSIII, fig. $4 c$ ). A similar form of the small globiferous exists in other cidaroids. It is near that which Agassiz and Clark have represented in Anomocidaris tenuispina, but here the terminal opening is much larger.

I observe in my specimens two kinds of tridactyle pedicellariae. In one, very large, the head reaches a length of $1.5 \mathrm{~mm}$ (fig. $4 \mathrm{a}$ ). The basal part, which measures $0.3 \mathrm{~mm}$ in width, continues insensibly with the blade. It has an apophysis with a smooth free border. The blade narrows gradually to the end that is round. It has extremely fine denticulations, a little irregular, on its edges that continue to its end without changing character. The perforations are vey small. The lower arcs are little developed. It does not seem to me that these pedicellariae have been seen by Meijere, who however indicated that the tridactyles reach $1 \mathrm{~mm}$ in length. The tridactyle pedicellariae represented by this author in fig. 115 appear to me to correspond to a second form of tridactyles, smaller than the preceding that I find very widespread in my specimens. But these tridactyles are always of fairly small size and the length of their valves does not exceed $0.4 \mathrm{~mm}$ (fig. $4 d$ ). The basal part, comparatively a little larger than in the large form, is a little more distinct from the blade. Its edges are not absolutely smooth, but its denticulations are scarcely visible and very dense. They are not as strong and, much closer, not as spaced as in the figure of Meijere. I have not observed intermediary tridactyles between these wo forms that have, moreover, a generally identical structure.

The specimens studied by Meijere were collected by the SIBOGA at depths varying from 69 to $94 \mathrm{~m}$ in the Sunda Archipelago.

The genus Acanthocidaris presently contains three species: A. curvatispinis, type of the genus, that comes from Mauritius. It is still known by only two specimens, one in the British Museum, the other in the Jardin des Plantes. A. hastigera was found by the ALBATROSS at the Hawaiian Islands at 23-222 fms; and finally, A. maculicollis. This last species is much closer to A. Hastigera than to $A$. curcavatispinis whose very long primary spines are thing and slightly curved. The dorsal side of the neck of the primary spines of A. hastigera is little colored and lacks the red dots that form longitudinal series in A. maculicollis. 


\section{Stereocidaris indica Döderlein}

(Pl. II, fig. 3 to 7; Pl. IV, fig 3 and 10; and Pl. XXIII, fig. 5)

Stereocidaris indica. Döderlein. 1901, p. 19.

Stereocidaris indica. Döderlein, 1904, p. 104; pl. X, fig. 1-2; pl. XI, fig. 1-6; pl. XII, fig. 3-10;

pl. XXXVI, fig. 5-9; pl. XXXVII, fig. 2-5.

Stereocidaris indica. Meijere, 1904. P. 18; pl , fig. 1; pl. XI, fig. 119 and 120; pl. XII, fig. 121. Dorocidaris indica, Lambert and Thiéry, 1910, p. 140.

Station 333. - $6^{\circ} 31^{\prime}$ N; $79^{\circ} 38^{3 / 4^{\prime}}$ E. - 401 fms. - A dozen specimens.

Amdaman Sea. - $480 \mathrm{fms}$. - One specimen.

Illegible label. - One specimen.

The two last specimens were labeled Cidaris Alcocki.

The individuals reach in general large dimensions. The diameter of the test varies between 40 and $50 \mathrm{~mm}$. Only one of the specimens from station 333 is smaller. Its test is only $18 \mathrm{~mm}$ in diameter.

St. indica can have variations that been very carefully studied by Döderlein. This author has even established four distinct varieties that he has called respectively africana, integra, sumatrana and carinata, mainly after characters of the spines. The first three varieties were found by the VALDIVIA off the coast of Somalia and the fourth at a point north of Sumatra. But these varieties seem to be based on essentially variable characters. It appears to me neither useful nor even possible to preserve them. Meijere, who has studied St. indica collected by the SIBOGA in the Sunda Islands, has the same opinion. He believes that these varieties are all at most local forms. He gives purely and simply the name St. indica to the three individuals of the SIBOGA. I likewise follow his example. I do not refer in a formal manner the specimens of the INVESTIGATOR to one of the varieties indicated by Döderlein. If I follow the example of this author, it would be necessary to create for these specimens a fifth variety, something that appears perfectly useless to me.

The characters of the test and the spines have been studied and described with much care by Döderlein. I have nothing to add to the description of this author. I shall content myself in reproducing here some photographs of specimens with or without their spines (Pl. II, fig. 3 to 7 and Pl. IV, fig. 19) and of some isolated large spines (Pl. IV, fig. 3).

The largest primary spines are elongated. Their length is a little variable but it always exceeds the diameter of the test. Their length is approximately one and half times the diameter. As Döderlein indicated, the spines have on their surface some slightly projecting ridges, but close together and with very fine and tight denticulations. There are approximately twenty of these ridges per spine. The spines of specimens of the INVESTIGATOR recall well those that Döderlein has described and figured in his varieties africana and integra. We can see by the photographs that I reproduce here, that there is some variation in the development or the closeness of the ridges and in the development of the denticulations that they have (Pl. IV, fig. 3).

The pedicellariae (Pl. XXIII, fig. 5) conform to those that Döderlein has described under the name small globiferous. These are in the four varieties that he distinguishes. I have never encountered large globiferous. All the pedicellariae that I observe have the very narrow head. Their form greatly recalls that of the tridactyle pedicellariae that I shall indicate later in St. Alcocki. The valves are thin and elongated. Their length is generally between 0.6 and $0.8 \mathrm{~mm}$. There are also 
smaller ones that do not exceed $0.4 \mathrm{~mm}$, but they are connected to the larger by all the possible intermediaries. I have never encountered large globiferous, enlarged and more or less stout like those that Döderlein has represented in pl. XXXVII, fig. $2 a$, fig. $3 a a^{\prime} d$, fig. $4 a$ and fig. $5 a a^{\prime}$ e.

The valves of the pedicellariae of the large form measure 0.8 to $1 \mathrm{~mm}$ in length. These valves are narrow. They recall absolutely those that Döderlein has figured in XXXVII, fig. $5 h, i$ and $k$, and fig. $7 d$ and $e$.. I.e., the valves of the small form with a narrow and elongated opening has some lateral small and pointed teeth and one or two larger terminal teeth. In the other pedicellariae, the head is no more than $0,4 \mathrm{~mm}$ in length. Outside the size, the valves are distinguished only by their more elongated opening. In summary, all the globiferous that I see correspond to the small form of Döderlein. Despite my searches, it has been impossible for me to find others.

\title{
Stereocidaris Alcocki (Anderson)
}

\author{
(Pl. VI, fig. 2, 3,4, 7, 8 and 9; Pl. XXIII, fig. 6)
}

Dorocidaris Alcocki. Anderson, 1894, p. 191.

Stereocidaris indica var. tricarinata. Döderlein, 1901, p. 20.

Stereocidaris tricarinata. Döderlein, 1906, p. 112; pl. IX, fig. 1 to 3; pl. X, fig. 7; p. XII, fig 1; pl. XXXXVI, fig. 1 to 3.

Andaman Sea. - $250 \mathrm{fms}$. - Six specimens whose diameter varies between 35 and $40 \mathrm{~mm}$.

Andaman Sea. - 130-250 fms. - Three smaller specimens (the diameter varies between 32 and $20 \mathrm{~mm}$ ).

Bay of Bengal. - 240-220 fms. - About a dozen dry specimens whose diameter varies between 30 and $20 \mathrm{~mm}$.

Station 33. - One specimen (diameter $37 \mathrm{~mm}$ ).

Laccadive Sea. - $13^{\circ} 47^{\prime} 49^{\prime \prime} \mathrm{N}$.; $73^{\circ} 7^{\prime} \mathrm{El}$ - $636 \mathrm{fms}$. - One specimen whose diameter is $26 \mathrm{~mm}$. (It is one of the two types described by Anderson.)

It is beyond doubt that the St. tricarinata collected by the VALDIVIA to the west of Sumatra, and so well studied by Döderlein, is identical to Cidaris Alcocki described by Anderson in 1894. The name Alcocki being prior to that of tricarinata chosen by Döderlein thus it must prevail. I must confess, moreover, that it was quite difficult, if not impossible, to recognize in the description of Cidaris Alcocki, the species found by the VALDIVIA. C. Alcocki was, in fact, established by Anderson after two specimens dredged in the sea of Laccadive at a depth of $636 \mathrm{fms}$. Only one specimen was sent to me These specimens were nearly the same size. Anderson indicated the diameter of the test was 26 and $25.75 \mathrm{~mm}$. Now, by unfortunate chance, the large spines of the two specimens did not have in their basal part, the three longitudinal ridges so characteristic and that Döderlein had wanted to recall in the name of tricarinaa that he applied to the species. The single specimen from the Laccadive Islands sent to me has preserved only two large spines (the largest has a length of $68 \mathrm{~mm}$, a number indicated by Anderson. In each of them there is only one basal ridge. Anderson was thus perfectly correct to say these spines "are covered with denticles, with their points distally directed, arranged in about 12 longitudinal ridges, one of which frequently projects, buttress-like, in the proximal third of the spine."

Now, it is not one ridge that Anderson saw on the two specimens that he used to establish the description of $C$. Alcocki, but three ridges that are normally present in the large spines of St. 
tricarinata. Moreover, the number of these ridges, as well as their form, is not absolutely constant. As Döderlein said in his memoir of 1906, p. 113, "die Zahl der vorspringenden Kanten is ubrigens shwankend... est finden sich aber solche mit nur einem dorsal Kiel bis zu solchen, wo funf der Kanten zu flügelartigen Kiele ausgebildet sind."

It is certain that if Anderson had in his hands the specimens that have been sent to me, he would have given a different description of the large spines and would have reported the three ridges that are so remarkable with which they are provided. I must remark, moreover, that all the specimens had the label "Cidaris Alcocki," but I shall add as well that this same name C. Alcocki was applied to individuals in the collection belonging to other species (Stereocidaris indica, Prionocidaris baculosa, etc).

I have little to add to the excellent description of Döderlein. The spines reach a great length. In the small individuals, they exceed in general twice the diameter of the test. In the largest, they are nearly twice the diameter. In specimens in which the diameter of the test measures 32, 31, 27 and $20 \mathrm{~mm}$, the largest spines are respectively 60,65, 50 and $50 \mathrm{~mm}$ in length. In an individual in which the test is $35 \mathrm{~mm}$ in diameter, the spine can reach $66 \mathrm{~mm}$ in length.

Anderson has given in his original description some numbers relative the various parts of the test (26 $\mathrm{mm}$ in diameter), The individuals studied by Döderlein were larger and their diameter reached respective 33 and $54 \mathrm{~mm}$ but the author has given no numbers relative to these specimens. I thus believe it good to indicate here the principal measurements that I have taken on a specimen whose test has a diameter of $40 \mathrm{~mm}$.

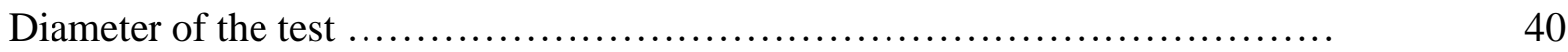

Height of the test .................................................. 34

Diameter of the apical system ............................................ 17

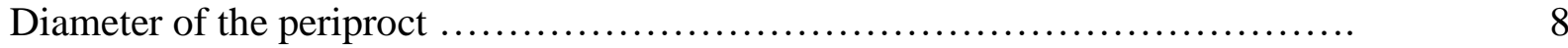

Diameter of the peristome ............................................. 9

Width of the ambulacral zones at the ambitus ................................ 5

Width of the interambulacral zones at the ambitus ............................ 19

Number of primary tubercles in each interambulacral zone (not including the rudimentary mamelon of the plate adjacent to the apical system). ................. 
The characters of the pedicellariae have been indicated by Döderlein. St. Alcocki has two kinds of globiferous and tridactyles. In the first kind of globiferous that merit the name of large globiferous, the valves have a length varying from 0.7 to $0.8 \mathrm{~mm}$ (Pl. XXIII, fig. $6 a$ ). In some pedicellariae, these valves are very stocky like those Döderlein has represented in pl. XXXVI, fig. $2 a, b$ and $c$. In others, they are narrower and a little more elongated, like those of figures $f$ and $2 d$. The small globiferous are of a very variable size. Their head can have only $0.2 \mathrm{~mm}$ in length and even a little less, or, to the contrary, become much larger. The valves are narrow. The opening is elongated, sometimes much longer than wide, sometimes nearly smooth, sometimes filled with small denticulations that become stronger toward the end. The opening is surmounted by one or two more developed plates.

The tridactyles have very thin valves, generally very elongated. The head, supported by a long peduncle, generally reaches $0.8 \mathrm{~mm}$ in length or even more (fig. $6 b$ ).

I recall that St. carinata has been encountered to the west of Sumatra, toward Nias Island and in the Strait of Siberut, at $0^{\circ} \mathrm{N}$ and $98^{\circ} \mathrm{E}$ at depths of 371 and 470 meters.

Döderlein has distinguished a variety teretispina in perfect conformity with the others by the structure of the test and the characters of the pedicellariae, but whose large spines do not have the three ridges characteristic of the test. They have only about a dozen longitudinal ridges with denticulations.

\section{Prionocidaris baculosa (Lamarck) and Prionocidaris baculosa var. annulifera (Lamarck)}

See for the bibliography:

Leiocidaris pistillaris and var. annuilifea. Döderlein, 1902, pl 692, pl. LIX, fig. 1-4. Phyllacanthus baculosa. H. L. Clark, 1907, p. 189.

Prionocidaris baculosa. H. L. Clark, 1925, p. 12.

\section{Prionocidaris baculosa Type.}

There are few echinoids that have had so many descriptions as Prionocidaris baculosa and its varieties, or, to say better, its variations, either to establish the limits of this species and to fix the variations by the different names, or to choose the genus in which it is convenient to place them. It appears useless to enter again here into a discussion on this subject. I shall return to the different memoirs of H. L. Clark, Mortensen and Döderlein in which this discussion has been approached. For my part, I place myself absolutely in the point of view of Döderlein who, in 1902, in the memoir cited above, distinguished in $P$. baculosa a typical form and a variety annulifera. I separate myself from Döderlein only in the name adopted by this author. Döderlein believed it necessary to give the species the name of Leiocidaris pistillaris. This denomination has been criticized by Mortensen and by H. L. Clark. The reasons given by these authors appear to me convincing. I shall adopt thus the denomination Prionocidaris baculosa that they both use. 
I believe equally that $\mathrm{H}$. L. Clark was perfectly correct in emphasizing the importance for identifying $P$. baculosa and the fixation of the limits that are appropriate for this species, the presence of the well-known purplish red dots that form on the basal region of the large primary spine very recognizable regular rows. The presence of these purplish dots or patches is completely characteristic for P. baculosa. H. L. Clark did not hesitate to attribute to them the greatest importance to identify $P$. baculosa.

The patches are seen in the specimens of $L$. pistillaris studied by Döderlein. We can recognize them in the photographs as well as in those of the typical form of the variety annulifera. I likewise see these dots in the various specimens collected by the INVESTIGATOR. I do not believe I am wrong in referring to either typical $P$. baculosa or to the variety annulifera the specimens I shall enumerate later. I must note on this subject that the spines of Stylocidaris bracteata (Agassiz) also has rows of red patches on their collar. The two species are very close, but we can distinguish them in particular by the characters of the ambulacral pores. H. L. Clark made the remark, moreover, that the patches of $P$. baculosa are purplish, while they are crimson in $S$. bracteata. This distinction is very subtle. It is often impossible to be specify the exact tint of coloration.

The individuals that I refer to $P$. baculosa type are in general of large size. The diameter of the test varies between 40 and $50 \mathrm{~mm}$. The spines are strong and elongated. They have at their base denticulations more or less developed on a variable length of the spine. The specimens of Station 291 have the test, i.e., the secondary spines, of a dark violet-brown color, while the large primary spines are pale gray. The individual coming from the Bay of Bengal ( $34 \mathrm{fms}$ ) has a paler test of pale yellow, with purple ambulacral zones. The primary spines are long, with reddish patches at the base. In the latter, in which the diameter of the test measures $27 \mathrm{~mm}$. The general color is fairly pale and a pinkish gray.

But whatever color they have, we can find in all these specimens, the characteristic red dots at the base of the large spines.

The specimens of $P$. baculosa come from the following localities:

Station 29. - $26^{\circ} 22^{\prime \prime}$ N.; $56^{\circ} 10^{\prime}$ E. - 48-49 fms. - Several large specimens. Bay of Bengal. $-23 \mathrm{fms}$. - One specimen.

Station 204. $-6^{\circ} 01^{\prime}$ N.; $81^{\circ} 16$ E. $34 \mathrm{fms}$; - One specimen.

\section{Prioncidaris baculosa var. annulifera}

The individuals of the variety annulifera resemble each other in color. They are generally smaller than the preceding except those from the Bay of Bengal ( $32 \mathrm{fms}$ ), in which the diameter reaches $45 \mathrm{~mm}$. In the others, the diameter is generally between 20 and $30 \mathrm{~mm}$. The test is ordinarily yellowish-white or pale yellowish gray. It is darker in the specimens whose label is illegible. But in all, the spines have the same characters. They are ringed in white or gray, and red or purplish-red. These spines are comparatively longer and a little narrowed than in the type. Their denticulations are little developed or even completely absent. The red dots of the collar region are very apparent. I note however that these dots are missing in five specimens whose information on the label was illegible. They are moreover identical to others in all their characters. The test of the five 
individuals is more sunken than in the others. But the large primary spines are strongly discolored. The red rings are much paler than usual and the basal region of these spines has completely lost its color. It is obviously to this accidental discoloration that is due the absence of colored dots. It is good to be forewarned of this possibility.

The specimens of $P$. baculosa var. annulifera have the color of the individuals has represent in color under the name Cidaris annulifera Lamarck in the Memoirs de la Soc. Sc. nat. de Neuchâtel, v. V, pl. II (1873). H. L. Clark has thought it necessarily recently to make this specimen a new species to which he has given the name Prioncidais badia (1925, pl. 14). But Mortensen thinks that these figures are those of the true iCidaris annulifera of Lamarck.

Here are the localities from which came the specimens of the var. annulifera collected by the INVESTIGATOR:

Bay of Bengal. - $32 \mathrm{fms}$. - One large specimen.

Bay of Bengal. - $34 \mathrm{fms}$. - One specimen.

Laccadive Islands. - 50-30 fms. - Two specimens.

Station 152. - Ceylon. - $26 \frac{1 / 2}{\mathrm{fms}}$. - Several small specimens.

Station 238. - $13^{\circ} 16^{\prime}$ N.; $93^{\circ} 08^{\prime}$ E. - 75-60 fms. - Three small specimens.

Without location. Five specimens (label illegible).

The authors do not agree on the importance of Prionocidaris annulifera. Shall we consider it a distinct species or is it better to consider it a variety of $P$. baculosa? I am of the latter point of view. The question of the hierarchy is not of very great importance, the essential thing is to distinguish the two forms.

\section{Stylocidaris bracteata var, albidens H. L. Clark}

Stylocidaris bracteata var. albidens. H. L. Clark, 1925, p. 23.

Station 238. - 32 $16^{\prime}$ N.; $93^{\circ} 08^{\prime}$ E. — Depth 60-70 fms. — Several specimens. Port Blair. $-60 \mathrm{~b} \mathrm{fms}$. Several specimens.

I must thank my excellent friend, Th. Mortensen, for the identification of these specimens.

This naturalist scholar is preparing at this moment a monograph of the Cidarida. He proposes, among others, to study St. bracteata and its var. albidens as well as the various forms of Prionocidaris baculosa. It thus appears useless to occupy myself here with Stylocidaris and because they will soon be described in depth by Mortensen with a competence to which I cannot pretend.

\section{Prionocidaris brevicollis (Meijere)}

(Pl. V, fig. 1, 4, 5 and 6; Pl. XXIII, fig. 3) 
Cidaris baculosa var. brevicollis. Meijere, 1904, p. 11; pl. V, fig. 1, 4, 5 and 6; pl. XXIII, fig. 3 .

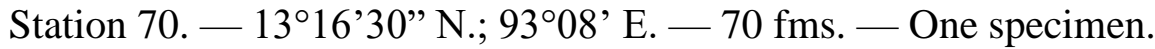

18 miles S. W. of the S. end of Interview Island (Andaman). - 240-45 fms. - Two spcimens.

Andaman Sea. - 130-250 fms. - Two specimens.

Without locality. - One specimen.

All these specimens were labeled Cidaris Loriolil.

The individuals remain always of fairly small size. The largest is that whose locality is missing and the two smaller are those of Interview Island, in which the diameter of the test measures respectively 22 and $10 \mathrm{~mm}$. These are those that approach the description and photographs of Meijiere. In the others, the diameter is respectively 15, 18 and $21 \mathrm{~mm}$. Here are some measures that I have taken of four specimens that I shall designate by the letters A to D.

\begin{tabular}{|c|c|c|c|}
\hline & $\begin{array}{c}\mathrm{A} \\
\mathrm{mm}\end{array}$ & $\begin{array}{c}\mathrm{B} \\
\mathrm{mm}\end{array}$ & $\begin{array}{c}\mathrm{C} \\
\mathrm{mm}\end{array}$ \\
\hline Diameter of the test .. & 22 & 21 & 18 \\
\hline Height $\ldots \ldots \ldots \ldots \ldots \ldots \ldots \ldots \ldots \ldots$ & 15 & 13 & 9 \\
\hline Diameter of the apical system..$\ldots \ldots \ldots \ldots$ & 11.5 & 10 & 9 \\
\hline Diameter of the peristome $\ldots \ldots \ldots \ldots \ldots \ldots$ & 9 & 8 & 8 \\
\hline Length of the longest spines ................. & 40 & 40 & 33 \\
\hline Diameter of the longest spines ............... & 3.2 & 2.2 & 1.8 \\
\hline
\end{tabular}

The species has already been indicated by Meijere, who considered it a simple variety of Cidaris baculosa. But I think, because of the characters of the pedicellariae, it can be made a separate species to which I preserve the name brevicollis.

This form has been described by Meijere after some specimens collected by the SIBOGA, some coming from the Strait of Sapeh, the others from the Strait of Molo. The diameter of the largest measures $43 \mathrm{~mm}$ and falls to $14 \mathrm{~mm}$ in the smallest. The first individual is thus notably larger than the largest specimen collected by the INVESTIGATOR, but it is without doubt that they are same form. A comparison between the photograph of Meijere (pl. II, fig. 7) and my photographs (pl. V, fig. 1, 4, 5 and 6) convincingly indicates their identify.

The spines are in fact very characteristic. They are very long. The length is much more than twice the diameter of the test. The collar region is very short. Meijere said that this region has no red dots so characteristic of Prionocidaris baculosa. In my largest specimen, I simply note no red dots distinct from each other, but red lines parallel to each other and little distinct. This continues in the direction of the rows of granules covering the surface of the rest of the spine. It seems to me, in addition, that in the photograph of Meijere, we can even perceive the indication of some similar lines on the collar region of some spines. Whatever it is, the width of these spines increases sensibly for some millimeters after the collar region. then the width decreases progressively up to the end. 
These large spines are armed, after the collar region, with large, conical granules with a large base. They end in a point sometimes round, sometimes acute and often directed toward the end of the spine. These granules are a little compressed laterally. They are arranged in extremely regular rows, not very dense, about a dozen per spine. These granules remain very distinct from one another on the widened part of the spine, i.e., on approximately a third of the length. After that, they become confluent, progressively sunken and end by constituting true continuous ridges whose free border still has more or less distinct sinuosities, especially in the largest individual. This is prolonged to the end of the spine, keeping the direction of the longitudinal rows of original granules.

The pedicellariae have special characters. It is good to insist on this. I have found in my specimens tridactyles and three different forms of globiferous (Pl. XXIII, fig. 3). The tridactyle pedicellariae have an elongated head with thin valves. The length can reach and even exceed 1 millimeter (fig. 3 c). These pedicellariae greatly resemble those that I have described above in Dorocidaris tiara. The basal part is short and fairly wide, ordinarily as long as wide. Its length is between one-fifth or one-sixth the total length of the valve. The valves remain very thin for all their length. But they are a little widened in their basal region whose border is more or less strongly sinuous. It is armed with protruding teeth, separated from each other. They are attenuated and nearer away from the base. They end by disappearing completely. The two last thirds of the valves are ordinarily completely smooth. A small hook ends the end of the valve.

The first kind of globiferous pedicellariae has the usual form with a terminal tooth. They have two sizes. In the larger, the valves are 0.6 to $0.65 \mathrm{~mm}$ in length. They are fairly narrow, elongated, very finely denticulated in the second half. The opening is rather small, bordered with small, conical and pointed spines. It is surmounted by a large hook (fig. 3 $b$ ). The valves of the small pedicellariae measure $0.2 \mathrm{~mm}$ in length. They are a little more widened comparatively than those of the large globiferous. The terminal opening is also a little larger. This opening is surmounted likewise by a terminal tooth.

The second kind of globiferous has a more swollen head than the preceding and their opening lacks the terminal tooth. The orifice, fairly large, is a little widened transversely. It has strong, conical, elongated and very pointed teeth on its border (fig. $3 a$ ). The basal part of the valve is very widened. Then it narrows abruptly after the middle of the valve up to the terminal opening. Its second part is a little inclined inward. This narrow part has on its edges some fairly spaced teeth, conical and pointed. The length of the valve is from 0.6 to $0.65 \mathrm{~mm}$. This kind of globiferous is identical to that which we know in some cidarids. For example, it approaches that which Mortensen has represented in 1903 (pl. IX, fig 22) in Cidaris affinis (Stylocidaris affinis). But here the valves are shorter and the opening less elongated but a little widened transversely.

There is finally a third kind of pedicellaria that we must consider globiferous. But it has fairly special characters (fig. $3 d$ ). The head measures $0.6 \mathrm{~mm}$ in length. The valves have a small, fairly developed basal part, higher than wide. Its form is an elongated triangle connecting progressively with the tube. The height of this part is nearly half the total length. It always exceeds two-fifths. The tube is thin. It ends in an opening, elongated, narrow, oval, two times longer than wide. Its borders are nearly smooth or have only some small, excessively fine, tight teeth. There is no special terminal tooth.

The pedicellariae of this genus have never been encountered in Prionocidaris baculosa. Their presence in our species does not permit considering it as a simple variety 
of $P$. baculosa. We can even ask if there is justification to create a new genus. For the moment, I content myself with considering $P$. brevicollis a distinct species, leaving it in the genus Prionocidaris.

\title{
Echinothuridæ
}

\section{Hygrosoma luculentum (Agassiz)}

\author{
(Pl. XXIV, fig. 1)
}

Phormosoma luculentum, Agassiz, 1879, p 204.

Phormosoma luculentum Agassiz, 1881, p. 97; pl. IX and X; pl X a, fig. 3-7; pl. XXXIX, fig. 8; pl. XL, fig. 31-36; pl. XLIV, fig. 225-27.

Phormosoma luculentum. Anderson, 1894, p. 195.

Hygrosoma luculentum. Mortensen, 1903, p. 59; pl. XII, fig. 20; pl. XIII, fig. 14 and 16.

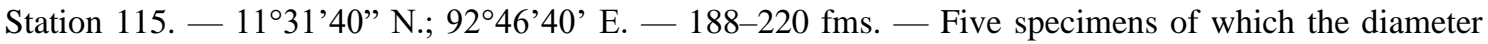
varies between 9 and $15 \mathrm{~mm}$.

Station 116. - $11^{\circ} 25^{\prime} 5^{\prime \prime}$ N.; 92 $47^{\prime} 6^{\prime \prime}$ E. — 405 fms. - Three large specimens.

Station 326. - 18 $8^{\circ} 30^{\prime}$ N.; 92 $58^{\prime} 30^{\prime \prime}$ E. - $1.100 \mathrm{fms}$. - Two young specimens (diameter 55 and $50 \mathrm{~mm}$ ). Andaman Sea. - $265 \mathrm{fms}$. - One specimen in very bad condition (diameter $14 \mathrm{~cm}$ ).

Andaman Sea. — $405 \mathrm{fms}$. - One large specimen (diameter $16 \mathrm{~cm}$ ).

Andaman Sea - $500 \mathrm{fms}$. - Three specimens (two of $10 \mathrm{~cm}$ and one of $4 \mathrm{~cm}$ diameter).

6 56 '56" N.; 72 53'30” E. - 450 fms. - One specimen in bad condition (12 cm diameter).

$13^{\circ} 27^{\prime}$ N.; 9314’30’ E. — $405 \mathrm{fms}$. — One large specimen (diameter $155 \mathrm{~mm}$ ).

Port Blair (Andaman Islands). — $274 \mathrm{fms}$. — Three large specimens and a fourth smaller one.

Anderson also cites Hygrosoma luculentum at station 145 (Laccadive Sea), $695 \mathrm{fms}$. I have not found specimens from this provenance in the collection sent to me.

$H$. luculetum is a well-known species whose characters are easy to recognize. The large triactyle pedicellariae are particularly very characteristic. I have nothing to add to the descriptions that Agassiz, Mortensen and Döderlein have given of this species. I shall content myself to reproduce (Pl. XXIV, fig. 1) photographs of some pedicellariae of different dimensions.

We know that $H$. luculentum, discovered by the CHALLENGER at the Philippine Islands and at the Aru Islands, has been found by the VALDIVIA to the west of Sumatra. It appears to be fairly frequent in the seas of India.

Araosona coriaceum Agassiz var. indicum nov. var.

(P1. VII, fig. 5; Pl. VIII, fig. 3 and Pl. XXIV, fig. 3

Asthenosoma coriacea. Agassiz, 1879, p. 201.

Asthenosoma coriacea. Agassiz, 1881, p. 88; pl. XVII a, fig. 5-7. 
Arceosoma coriaceum Mortensen, 1903, p. 23; pl. XII, fig. 27; pl. XIV, fig. 5.

Asthenosoma coriaceum. Agassiz, 1905, p. 115; pl. LII.

Arceosoma coriaceum. Döderlein. 1907, p. 122; pl. XIV, fig. 1; pl. XXXIII, fig. 1.

Station 333. - $6^{\circ} 31^{\prime}$ N.; $79^{\circ} 38^{3 / 4^{\circ}}$ E. - $401 \mathrm{fms}$. - One large specimen.

The specimen measures $155 \mathrm{~mm}$ in diameter. It is in a fairly good state of preservation, but the spines of the dorsal surface have nearly all been scraped off. The ventral surface is better preserved.

Here are the principal dimensions that I have taken of this individual:

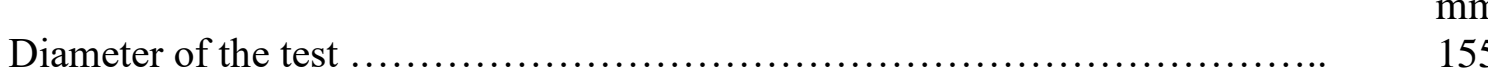

Diameter of the apical system ............................................. 18

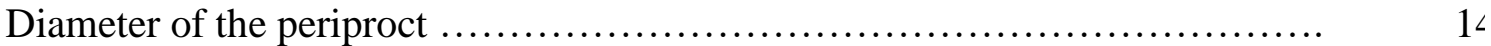

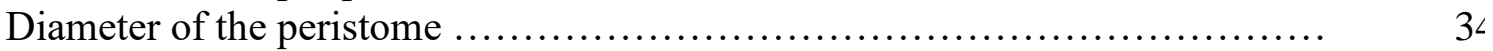

Width of the ambulacral zone at the ambitus .................................. 31

Width of the interambulacral zone at the ambitus .............................

Width of the poriferous zone at the ambitus ................................... $\quad$.

Number of ambulacral plates in each row on the dorsal surface .................. $3 \xi$

Number of ambulacral plates in each row on the ventral surface ................ 34

Number of interambulacral plates in each row on the dorsal surface ............. $2 t$

Number of interambulacral plates in each row on the ventral surface ............ 2(

By all the exterior characters of the test, this specimen corresponds perfectly to the description and the figures that have been published by the authors, in particular by Döderlein in 1907 of A. coriaceum. Also I believe I am able to refer to this species, though the pedicellariae do not conform absolutely to those that have been described by this latter zoologist, the A. coriaceum that he has studied and that comes from the coast of Somalia ( $2^{\circ} 58^{\prime}$ N., $47^{\circ} 6^{\prime}$ E., $1,289 \mathrm{~m}$ ). I am of the opinion to make a distinct variety of it that I propose to call indicum.

I have encountered on my specimen four kinds of pedicellariae, large tridactyles of two kinds, small tridactyles and trifoliaes (Pl. XXIVV, fig. 3).

The large tridactyles are very similar to those that Döderlein called "laternenförmig: that he represents in pl. XXXVIII, fig. $1 a$. The valves of these pedicellariae reach in the specimen of Döderlein up to $2.8 \mathrm{~mm}$ in length. In mine, they do not quite reach $2 \mathrm{~mm}$. It is difficult to obtain intact valves from the pedicellariae in the preparations. I reproduce however, fig. $3 a$, two of the valves as well as the terminal part of two other valves seen from the front. We see that the blade, at first very narrow with the edges folded inward, widens very rapidly at the end into a terminal palette as is indicated in the photographs of Döderlein. But this palette, instead of being triangular, pointed and longer than wide with very slight sinuosities, is nearly as wide as long. It is not pointed, but often ends in a truncated edge. It has one or two wide and fairly deep sinuosities, determining the formation of large marginal lobes. The length of the narrow part of the blade is variable. But it always exceeds that of the terminal palette as well as that of the basal part. The latter is very wide, fairly short, notably wider than long. It does not reach a third of the total length. 
The other tridactyle pedicellariae are smaller. The length of their head generally varies around $1 \mathrm{~mm}$. It can, however, exceed this length (fig. $4 d$ ). The narrow region of the blade of their valves is much shorter than in the preceding form, while the terminal palette is more elongated. In some pedicellariae, the narrow part is longer than the palette. In others, it equals it and can even be shorter. This palette is a form similar to that we see in the large tridactyles. It is always round at its end. It has on each edge two or three large sinuosities determining the formation of marginal lobes. The triangular basal part is higher than wide. It ordinarily exceeds a third of the total length. The head of these pedicellariae, when the three valves are united, has the form of a triangular pyramid with a rounded end as in the type of $A$. coriaceum.

The tridactyles of the second form have thin, elongated valves with parallel edges and a rounded and not narrowed end (fig. $3 \mathrm{~b}$ ). The basal pat is fairly wide but short. It continues insensibly with the blade. The length of the head of these pedicellariae can each $0.8 \mathrm{~mm}$. Pedicellariae of his for have not been reported by Döderlein. In contrast, I find in my specimen some smaller tridactyles (fig. $3 \mathrm{c}$ ) that recall those that Döderlein has represented in pl. XXXVII, fig. $1 i$ and $k$. They do not appear to reach a great length. The valves measure 0.4 to $0.5 \mathrm{~mm}$ in length. The blade sometimes has on its borders indistinct sinuosities and often completely missing. The basal part is a little shorter than a third of the total length, and nearly as wide as long.

The trifoliate pedicellariae (fig. $3 e$ ) whose valves measure $0.4 \mathrm{~mm}$ in length, do not have the narrowed valves that Döderlein has represented in pl. XXX, fig. $1 l$. To the contrary, their blade widens progressively from the base to the end that is fairly wide. The width of these vales at their end is half their total length.

It has been impossible for me to find a single pedicellaria recalling the second form of tridactyle that Döderlein has represented in pl. XXXVIII, fig. $1 b$ to $h$ that he calls "zungenförmig". In these, the valves remain wide for their entire length with sinuous edges. The blade is not separated from the basal part by an apparent constriction but is continuous with the basal part. This form of pedicellariae appears to be missing in the variety indicum and would be replaced by tridactyles with narrow, elongate valves.

The spicules of the ambulacal tube are identical to those of $A$. coriacum type.

The differences in the character of the pedicellariae appear to me to justify the creation of a distinct variety.

I recall that $A$. coriaceum has been found by the CHALLENGER at the Fiji Islands and Tongatabu, as well as New Zealand at depths between 18 and $315 \mathrm{fms}$. The species has been found by the VALDIVIA off the coast of Somalia as I have said above.

\section{Phormosoma indicum Döderlein}

$$
\text { (Pl. VII, fig. 1, 2, } 4 \text { and 6; pl. VIII, fig. } 2 \text { and pl. XXV, fig 1) }
$$

Phormosoma indicum. Döderlein, 1905, p. 621.

Phormosoma indicum. Döderlein, 1907, p. 130; pl. XV, fig. 1 and 2; pl. XXXVIII, fig. 2 and 3.

Phormosoma indicum. H. L. Clark, 1924, p. 3. 
? Phormosoma bursarium. Meijere, 19094, p. 28.

Station 116. - $11^{\circ} 25^{\prime} 5^{\prime \prime}$ N.; 92 47'6" E. — 405 fms. — One small specimen (diameter $5 \mathrm{~mm}$ ).

Station 118. - 13³1"40” N.; 92॰46’40” E. - 188-220 fms. — Two specimens.

Station 131. - $16^{\circ} 01^{\prime}$ N.; $81^{\circ} 25^{\prime}$ E. - $410 \mathrm{fms}$. - Several specimens.

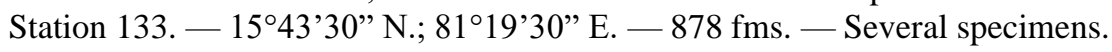

Station 142. - $14^{\circ} 13^{\prime} 8^{\prime \prime}$ N.; $80^{\circ} 24^{\prime} 2^{\prime \prime}$ E. - $573 \mathrm{fms}$. - One very small specimen (diameter $18 \mathrm{~mm}$ ),

Station 197. — 9 9 $34^{\prime \prime} 57^{\prime \prime}$ N.; 75³6’30" E. — 406 fms. — Two specimens of which one in fairly bad condition.

Station 222. - $13^{\circ} 27^{\prime}$ N.; 9314'30” N.; 93¹4’30” E. — 405 fms. — Three specimens.

Station 276. - $7^{\circ} 11^{\prime}$ N.; 76³ $30^{\prime}$ ” N.; 76³5’30” E. - 1,006 fms. Two specimens in very bad condition.

Station 280. - $11^{\circ} 29^{\prime} 45^{\prime \prime}$ N.; $80^{\circ} 2$ '30” E. - $446 \mathrm{fms}$. - Several specimens.

Station 297. - $25^{\circ} 11^{\prime}$ N.; $57^{\circ} 15^{\prime}$ E. - 700-680 fms. - Several specimens.

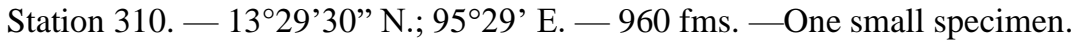

Station 314. - $13^{\circ} 56^{\prime}$ N.; $93^{\circ} 36^{\prime}$ E. - 613 fms. - One large specimen.

Station 315. - $16^{\circ} 6^{\prime}$ N.; $92^{\circ} 29^{\prime}$ E. - 705 fms. - One specimen.

Station 332. - 10²4' N.; 92 46'15” E, — 279 fms. - Several specimens.

Station 333. - 6 $6^{\circ} 31^{\prime}$ N.; $79^{\circ} 38$ 3/4" E. — $401 \mathrm{fms}$. — One small specimen (diameter $25 \mathrm{~mm}$ ).

Station 337. - $9^{\circ} 43^{\prime}$ N.; $75^{\circ} 35^{\prime}$ ' E. - 271 fms. - One large specimen.

Andaman Sea. — 265 fms. — Five specimens.

Andaman Sea. - 271 fms. - Several specimens.

Andaman Sea. — $405 \mathrm{fms}$. — Two specimens.

Andaman Sea. - $480 \mathrm{fms}$. - Five small specimens of which three in very bad condition; in the two others the diameter is 27 and $14 \mathrm{~mm}$.

Off the coast of Kristna. — $753 \mathrm{fms}$. - One very small specimen (diameter $21 \mathrm{~mm}$ ).

Bay of Bengal. - 1,300 fms. - One specimen.

Persian Gulf. - 1,000 fms. - One specimen.

Persian Gulf. - $740 \mathrm{fms}$. - One specimen in very bad condition.

Ph. indicum was described by Döderlein after specimens collected by the VALDIVIA either off the east coast of Africa or to the west of Sumatra at depths between 470 and 977 meters. The specimens found by the INVESTIGATOR at numerous locations in the seas of India and the Persian Gulf conform absolutely to the excellent description of Döderlein, to which I have nothing to add. The tridactyle pedicellariae have the elongated, thin valves. They conform to the photographs by this author in 1907 (Pl. XXVIII, fig. 2 and 4). I reproduce here some photographs of these pedicellariae (Pl. XXV, fig. 1) as well as some views of the dorsal surface (Pl. VII, fig. 1, 2 and 6 and Pl. VIII, fig. 2).

The specimens of the INVESTIGATOR have a diameter that varies generally between 50 and $70 \mathrm{~mm}$. Some others are larger. In the largest, the diameter of the test exceeds slightly $110 \mathrm{~mm}$. In the specimen that I represent in Pl. VII, fig. 1 and 4, that came from Station 131 , and whose diameter is $83 \mathrm{~mm}$, there is a slight anomaly of the apical system having the madreporite plate. This plate has the usual size. It is transversely oval, and its contour is clearly limited. The pores cover the entire surface, but they extend also to two adjacent plates that have their surface completely covered with pores identical to those of the madreporite plate.

Döderlein is of the opinion that the Phormosoma collected by the SIBOGA at numerous localities in the Sunda Islands, and that Meijere called Ph. bursarium, are at least in part $P h$. indicum. This seems probable to me, but I can say nothing specifically on this subject, not having seen the specimens of the SIBOGA. The two species, busarium and indicum, are very close. 
Ph. indicum has been reported recently at the Cape by H. L. Clark. The species extends thus from Zanzibar to the southern end of South Africa. It must be very widespread in the Indian Ocean if the Phormosoma found by the SIBOGA in the Sunda Archipelago is referred to this species.

\title{
Phormosoma verticillatum Mortensen
}

\author{
(Pl. VII, fig. 3; Pl. XXIV, fig. 2)
}

Phormosoma verticillatum. Mortensen, 1904, p. 90; pl. IV, fig. 1 and 2; pl. V, fig. 15-17. Phormosoma verticillatum. Agassiz and H. L. Clark, 1909, p. 156.

Station 255. - 9²6’30" N.; 91 ${ }^{\circ} 56^{\prime} 30^{\prime \prime}$ E. - 869-913 fms. — Two specimens in very bad condition. Station 290. - 29²4"53" N.; 5743' E, - 833-733 fms. - Several specimens.

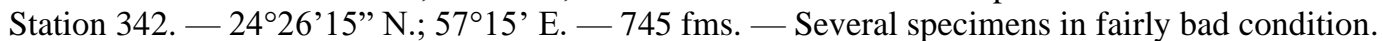
235' $15^{\prime}$ " N.; 56 34' E, - 811-647 fms. - Several specimens.

$11^{\circ} 47^{\prime} 6^{\prime \prime}$ N.; 735 ' $30^{\prime \prime} \mathrm{E}$, — 1,070 fms. — Three specimens in fairly bad condition.

Phormosoma verticillatum was described in 1904 by Mortensen after some specimens coming from the dredges of the INVESTIGATOR that were labeled Bay of Bengal, $678 \mathrm{fms}$. I have not encountered in the collection I received Phormosoma having this indication. The specimens that I refer to $P h$. vericillatum come from the five localities cited above.

The species has been perfectly described by Mortensen. It is very recognizable. I have nothing to add to the description that this author has given of the test and spines. I shall content myself to reproduce here a photograph of the dorsal surface that shows in a clearer manner than the photograph given by Mortensen in pl. IV, fig 2 of his memoir, the characters of this surface and an enlarged view of the apical system (Pl. VII, fig. 3 and 4).

As for the pedicellariae, Mortensen says that they are completely like those of $P h$. placenta. I observe, in fact, principally tridactyl pedicellariae with a fairly enlarged head, strong, whose valves are $0.8 \mathrm{~mm}$ in length by $0.4 \mathrm{~mm}$ ini width at the base. They are identical to the pedicellariae of Ph. placenta (Pl. XXIV, fig. $2 b$ ). The valves resemble absolutely those that Mortensen represented in 1903 (Ingolf Echinoidea, pl. XII, fig. 2). But I have found, in addition, although rarely I must say, other tridactyle pedicellariae whose form is very different from the preceding. Their head is small. They measure 0.3 $\mathrm{mm}$ in height. The valves are triangular, pointed, one and a half times higher than wide. They narrow regularly and progressively from the base to the end. The basal part is less than two-thirds of the total length. The blade is very small and oval (fig. $2 a$ ). Are these pedicellariae a different form or a stage in the development of the ordinary tridactyle pedicellariae? I do not know. I reproduce here photographs of both of the valves.

The spines are completely characteristic with their verticilles of spinules. They have been described in a very complete manner by Mortensen. This author emphasizes the affinities of $P h$. verticellatum and $P h$. placenta. The first species is distinguished very easily not only from $P h$. placenta, but also from $P h$. indicum that lives in the same area by the characters of the spines. These are always finer than in Ph. indicium and placenta, but especially they form a very uniform covering on the dorsal surface that gives them a very different appearance than that known in Ph. indicum and placenta. 


\title{
Sperosoma biseriatum Döderlein
}

\author{
(Pl. XXV, fig. 2)
}

Sperosoma biseriatum. Döderlein, 1901, p. 20.

Sperosoma biseriatum. Döderlein, 1907, p. 150; pl XIX, fig. 1 and pl. XI, fig. 1.

Arabian Sea. -740 fms. - One specimen.

Off Travancore. - $430 \mathrm{fms}$. - One specimen.

7²"30" N.; 79³6’ E. - 457-589 fms. Two specimens.

The two first specimens are of large size. They measure respectively 170 and $165 \mathrm{~mm}$ in diameter. But they are not in very good condition. In one of them, the ventral surface has been scraped off. Moreover, the jar that contained the individuals has been broken. The alcohol evaporated and the two specimens were strongly folded and curled. I have had a great deal of difficulty to spread them out in a plane. The two other individuals are still more incomplete. In one of them, more than half, in the other nearly half of the test is missing. However, the portions that remain are very well preserved. We recognize the species very well.

The characters of these individuals absolutely concur with those that Döderlein has described in Sp. biseriatum. The large tridactyl pedicellariae, with very large and very wide valves, with slightly sinuous borders, are very characteristic (pl. XXV, fig. 2).

The type of the species was encountered by the VALDIVIA off the east coast of Africa at $0^{\circ} 24^{\prime}$ 'S. and $42^{\circ} 49^{\prime}$ E. at 1,109 meters depth.

\section{Sperosoma armatum nov. sp.}

(Pl. VIII, fig. 1 and 7; Pl. XXV, fig. 3)

2437’30” N.; 62²’39” E. - 1,000 fms. - One specimen.

The specimen is not in a very good state of preservation. The test is fairly strongly flattened. Some portions are missing, both on the dorsal surface and on the ventral surface. The large primary spines are all absent on the ventral surface where we see only small spines. On the dorsal surface, the large spines are in part preserved but they are nearly broken toward their end.

Here are the principal dimensions that I have taken on this individual:

$\quad \mathrm{mm}$

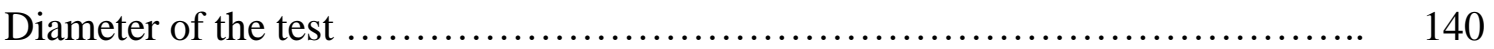

Diameter of the apical system ............................................ 20

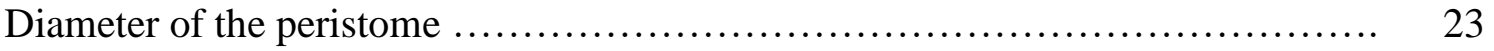

Width of an ambulacral zone at the ambitus .................................. 40 
Width of an interambulacral zone at the ambitus .............................. 45

Width of an ambulacral zone toward the sixth plate on the ventral surface. ........ 40

Width of an interambulacral zone toward the fourth plate on the ventral surface .... 16

Number of ambulacral plates in each series on the ventral surface ................ 12

Number of interambulacral plates in each series on the ventral surface ........... 10

Number of ambulacral plates in each series on the dorsal surface ................ 25

Number of interambulacral plates in each series on the dorsal surface. ........... 15

The color is an uneven very dark purple. This color becomes nearly black on the apical system.

This system is small. It is covered with a thick integument, strongly pigmented. It is nearly impossible to distinguish the contours of the plates. I did not dare submit this region to a treatment of potassium hydroxide or hydrogen peroxide for fear of causing dissociation. I can say nothing about the ocellar plates. The plates of the periproct are small, round and fairly separated from each other.

The characters of the ventral surface greatly recall Sperosoma biseriatum. The interradial plates alternate in each series but are very narrow for a large part of the area. The latter remains very narrow up to near the fifth plate. It is only in the area of the ambitus that the width of the area increases abruptly and rapidly. The ambulacral areas are, to the contrary, extremely wide in the middle region. The narrow a little in the area of the ambitus.

The middle of the interambulacral zones follows, on the ventral surface, an extremely accentuated zigzag line. The first plates are nearly as long as wide. They widen progressively, then very rapidly toward the ambitus. Only the last two or three plates have one or two large primary tubercles. These tubercles are not present on the plates nearer the peristome. I can say nothing of the primary spines that are completely absent. The other spines are fine and fairly long. They have extremely fine and dense denticulations.

The ambulacral zones of the ventral surface contain on each side four very regular series of plates. The two externals ae very large. At first, they are nearly as large as the interambulacrals at the same level. These zones greatly recall those of Sp. biseriatum.

But on the dorsal surface, the arrangements ae very different from those that we know in the latter species. The plates are in fact notably longer and less numerous, in both the ambulacral zones and in the interambulacral zones. The height of an ambulacral plate in the middle region is $3 \mathrm{~mm}$ on average. Primary tubercles appear here and there in an irregular manner, with the same dimensions over all the area. We also encounter them on the plates adjacent to the apical system. The interambulacral plates of the dorsal surface are also longer and less numerous than in Sp. biseriatum. The height of these plates, in the middle region of the areas, is $5 \mathrm{~mm}$. Each plate has in general two primary tubercles. One is toward the external border, the other near the internal corner. Thee tubercles form two fairly regular rows. The small tubercles are not numerous and very small.

The small peristome is ordinarily covered in each row with seven successive plates. These plates are slightly curved. Each has an arc of three to five tubercles.

The large primary spines ae all missing from the ventral surface, but they are preserved in large part on the dorsal surface. These spines are fine and elongated. I do not see them absolutely intact. All are broken at their end. The largest is intact for a length of $25 \mathrm{~mm}$. These spines are no more than $0.5 \mathrm{~mm}$ at the base. They are very finely striated and often 
they have extremely fine denticulations on nearly all their length. But I have encountered, however, those that are completely smooth. The small spines, very fine and very pointed, have a length between 5 and $7 \mathrm{~mm}$.

It is the pedicellariae that offer in Sp. armatum the most characteristic arrangements. I see three kinds of tridactyle pedicellariae, of which two are of large size, and the trifoliate (Pl. XXV, fig 3).

The large tridactyle pedicellariae themselves are of two very different forms. In one, the head measures on average $1 \mathrm{~mm}$ in length or even a little more. The fairly short and wide valves greatly recall those of the large pedicellariae of Sp. Grimaldii (see Mortensen "Ingolf Echinoidea 1903, pl. XIII, fig. 12). These valves also recall the large tridactyles of Sp. biseriatum, but their edges are perfectly regular and not sinuous as is the case in the latter species. In $S p$. armatum, the basal part of the valves is extremely developed. It is nearly half the total length, while in Sp. Grimaldii and biseratumi, this region is shorter. The apophysis is high and fairly thin. These valves are extremely wide. They scarcely narrow toward their end that is broadly round. The width at their base can reach 0.70 to $0.75 \mathrm{~mm}$ (fig. $3 \mathrm{~b}$ ).

The other large tridactyle pedicellariae are very remarkable (fig. $3 a$ ). Their valves have the form of very thin lamellae, extremely wide and relatively short. But the absolute dimensions of these valves are very great. They measure, in fact, $2.40 \mathrm{~mm}$ in length by $1.60 \mathrm{~mm}$ in width. The basal part is extremely short. It is one third the total length. The apophysis is fairy long but very narrow. The rest of the blade forms an extremely thin lamella with very fine and regular perforations. The edges are very regular and smooth and have a broadly round end. The tissue of these valves is very delicate. It is difficult to obtain intact valves in the preparations. The head of the entire pedicellaria is short, thick and massive. The large tridacyle pedicellariae do not appear very widespread, but they are completely special. I do not know of Sperosoma nor even of Echinothuridæ in which similar pedicellariae have been found.

The tridactyl pedicellariae of the third kind are small. Their head measures $0.5 \mathrm{~mm}$ in length. The valves recall those of Sp. Grimaldi represented by Mortensen in 1903 (pl. XIII, fig. 2). But they are larger than in this last species and they scarcely narrow toward their end. The length of the basal region exceeds a third of the total height. The blade is wide. It enlarges progressively towards half its length where it reaches its maximum width. Then it narrows again to its end (fig. $3 c$ ).

The trifoliate pedicellariae do not have special characters. Their blade widens progressively from the base to the end. It is two and a half times longer than wide (fig. 3 d).

SIMILARITIES AND DIFFERENCES. Sp. armatum is distinguished easily from all the other species of the genus Sperosoma by the existence of very large tridactyle pedicellariae whose valves have the form of very thin lamellae and nearly as wide as long.

\section{Diadematidæ}




\section{Diadema saxatile (Linné)}

I refer for the bibliography of this species to the work of Mortensen on the echinoids of the Danish expedition to Siam (1904, p. 9) in which the Danish naturalist scholar has clearly distinguished the four species of Diadema, D. saxatile (Linné), Savignyi Michelin, antillarum Philippi and mexicana Agassi that had generally been confused with it. Alone, $D$. saxitille is found in the Indo-Pacific domain. D. antillalrum is the Atlantic species that we find in warm regions on the two sides of this ocean. D. mexicanum is specific to the Pacific (coasts of Mexico and Central America). D. saxatile lives on the east coasts of Africa.

I shall add that a fifth species, D. ascensionis was described in 1910 (p. 55) for a species coming from Ascension. These five species are perfectly distinct from each other and are easily recognized by the characters of the pedicellariae.

The collection of the INVESTIGATOR contains a single specimen of Diadema that corresponds perfectly to $D$. saxatile coming from Muscat (Cap. C. M. Gilchrist). I also refer to this species a small specimen without spines coming from Port Blair.

\section{Echinothrix calamaris (Pallas)}

See for the bibliography:

Echinothrix calamaris. Döderlein, 1902, p. 698, pl. LIX, fig. 9; Pl. LXIII, fig. 6.

Echinothrix calamaris. Var. Desori. Döderlein. Ib., p. 699, pl. LXIII, fig. 6.

Echinothrix calamaris. Meijere, 1904, p. 54.

Echinothrix calamaris. Mortensen, 1904, p. 30, pl. III, FIG. 5, 13, 17, 21, 30; PL. IV, fig. 7; pl. V, fig. 3 and 11.

Echinothrix calamaris. A. Agassiz and H. L. Clark, 1908, p. 116 and 117.

Echinothrix calamaris, H. L. Clark, 1908, p. 302.

Echinothrix calamaris. H. L. Clark, 1923, p. 373.

Station 78. - One specimen

Inglis Island; Andaman. - One specimen.

Andaman. - Four specimens of small and medium dimensions.

Table Island. - One dry specimen.

Without indication of location. - Several specimens of various dimensions. Some of pale brown color, two other blackish and a last nearly completely colorless.

Echinothrix diadema Linné

(E. turcarum Schynvoelt)

Echinothrix diadema. Linné, 1758, p. 664. 
Echinothrix diadema. Peters, 1854, p. 116.

Echinothrix turcarum. A. Agassiz, 1872-74, p. 120 and 416; pl. II $a$, fig. 34 to 48; pl. III a, fig. 3; pl. XXIV, fig. 33 to 36 .

Echinothrix diadema. Loriol, 1883, p, 17.

Echinothrix diadema. Meijere, 1904, p. 50.

Echinothrix diadema. Mortensen. 1904, p. 31.

Echinothrix diadema. A. Agassiz and H. L. Clark, 1908, p. 1.

Echinothrix turcarum. Rudmose Brown, 1910, p. 23.

Echinothrix turcarum. Rudmose Brown, 19109 a, p. 38.

Table Island. - A small dry specimen.

Without indication of locality. - Several specimens of various dimensions.

Most authors have attributed previously three different species to the genus Echionthrix, E. diadema Linné (= E. turcarum Schynvoelt), E, calanaris_(Pallas), and E. Desori L. Agassiz, while recognizing the last two species were very close and that very often it was impossible to distinguish them from each other. Recent zoologists, Mortensen, Döderlein, Meijere and H. L. Clark, have definitively united them. However, Döderlein still preserved, in 1902, E, Desori with the title of variety of E. calamaris. But, after this period, only E. diadema and $E$, calanaris have been maintained. I only cite for the record the opinion of Lovén who, in 1887 (p. 187), united the three species of Echinothrix into one only that he called, E. diadema.

E. diadema and calamaris have not always been correctly interpreted. I am persuaded that the two species have sometimes been taken for each other. It is, however, very easy to distinguish them, either by characters of the spines or by microscopic examination of the spicules of the tube feet or even by the pedicellariae. We find the work of Agassiz and H. L. Clark (1908, p. 116) a precise indication of the differences that permit distinguishing the two species immediately. However, these authors do not mention the form of the spicules that is very important to know for the distinction of these species. I recall that the spicules are triradiate in E. calimais (see the figure of Mortensen, 1904, pl. III, fig. 17) and that they consist, to the contrary, of small fenestrate plates, elongated and irregular in E. diadema (see Mortensen, $I b$., fig. 24 and 27). The differences are obvious and do not permit error in identification. The pedicellariae have been carefully described and figured by Mortensen.

E. calamaris and diadema are widespread in all the warm seas of the Indo-Pacific domain. They have been very frequently captured in numerous localities.

\section{Chatodiadema granulatum Mortensen}

(Pl. VIII, fig. 4 and 5; Pl. IX, fig. 1 to 3 and Pl. XXV, fig. 4)

Astropyga pulvinata (pro part). A. Agasiz, 1881, p. 70.

Astropyga radiata (pro part). Sluiter, 1895, p. 68,

Choetodiadema granulatum. Mortensen, 1903, p. 1.

Chotodiadema granulatum. Meijere, 1904, p. 54; pl. III, fig. 28; pl. XI, fig. 101; pl. XIV, fig. 205-208. 
Chatodiadema granulatum. Mortensen, 1904, p. 22, pl. I, fig. 1, 3, 21 and 22; pl. III, fig. 11; pl. IV, fig. 1, 4, 13-1, 24 and 32; pl. V, fig. 10, 18, 19, 22 and 25.

Chotodiadema granulatum. Agassiz and H. L. Clark. 1908, p. 124-125.

Chatodiadema granulatum. R. Rudmose Brown, 1910 a, p.39.

Coast of Orissa. - 20 fms. - 24 February 1909. — Bengal Fisheries "Golden Crown". — A large specimen (diameter of the test $10 \mathrm{~cm}$ ),

Gopalpore. - 25-28 fms. - 23-27 September 1909. — Four specimens: in the largest, the diameter is 105 $\mathrm{mm}$, in the others, it varies between 55 and $81 \mathrm{~mm}$. Three other individuals are smaller. Their diameters measure respectively 32,26 and $24 \mathrm{~mm}$.

Station 90. - 8 miles to the south of Puri. - About a dozen small specimens in which the diameter of the test is between 17 and $25 \mathrm{~mm}$.

Santapalii, Madras Presidency, "Golden Crown". - September 1909. - Three specimens, two of which measure $73 \mathrm{~mm}$ in diameter. In the third, smaller, the diameter is only $54 \mathrm{~mm}$.

A last jar contains five specimens, three large measuring respectively 90,70 and 50 $\mathrm{mm}$ in diameter and two very small. The jar has several labels: Station 85, 30-31 fms; Station 90, 28-30 fns; 18 miles S. W. of Puri, 25 fms; 8 miles S of Puri, 13 fms and 4 miles from Ganjam, $23 \mathrm{fms}$. There is in addition some debris of four small individuals in very bad condition.

The specimens from Santapalii are in an excellent state. The spines are nearly all preserved on the ventral surface of the test. In the others, they are more or less completely denuded. We find in the latter, and especially in the two large individuals, elegant patches of dark blue in the living animal that follow the ambulacral zones, In the specimens in alcohol, they are nearly black. The general color of the preserved individuals is greenish yellow.

The original description of Mortensen was made from a specimen from the Gulf of Siam, in which the diameter was $90 \mathrm{~mm}$. The individuals of the SIBOGA studied by Meijere are smaller. Finally, in those from Kerimba, studied by Rudnose Brown, the diameter varied between 55 and $43 \mathrm{~mm}$.

Very careful descriptions of Chatodiadema granulatum published by Mortensen and by Meijere. I have only very little to add to the remarks made by those made by these authors on this very interesting species. However, as the photograph reproduced by Mortensen in 1904 (pl. I, fig. 1) does not clearly show the contours of the plates of the apical system, I believe I should give some photographs of the magnified system of specimens of different sizes (Pl. VIII, fig. 4 and 5 and PL IX, fig. 1 and 2). As we can see, the system forms a very regular pentagon that, in the large specimen, measures $23 \mathrm{~mm}$ between the top of a genital plate and the middle of the exterior border of the opposite ocellar plate. The sides of the pentagon are slightly concave. The genital plates are of medium dimensions. They have a triangular form, with strongly truncated lateral corners. They are nearly as wide and as $\mathrm{v}$, with a narrow distal corner on which the rather small gonopore is very near. Not only are the lateral corners of these plates truncated, but it sometimes happens that the portion of the adjacent plate of the suture outside the shortened side, is separated from the rest by a transverse line parallel to this suture. It happens on the specimen represented in Pl. IX, fig. 3, from the genitals 11 and 5 on only one side. The ocellars are rectangular, very wide, at least three times wider than long, with a very small opening. The external side of each plate is formed of two sightly concave borders that together form a small protrusion that corresponds to the end of the ambulacral 
zone that ends at the ocellar plate. The ocellar that separate the two genitals 1 and 5, that I reported the fragmentation above, is broken into three nearly equal fragments by two transverse sutures. The plates that cover the peripheral region of the periproct have first an external circle of large, unequal plates, then by a second circle of much smaller plates, and finally by extremely small plates arranged without order, They leave bare a central circle measuring approximately $8.5 \mathrm{~mm}$ in diameter,

In the smaller specimens in which the total diameter of the test measures respectively 32, 20 and $17 \mathrm{~mm}$, the apical system is 11,9 and $6 \mathrm{~mm}$. The ocellar plates are comparatively a little less wide than in the larger individuals. In the specimens in which the diameter is 33 and $20 \mathrm{~mm}$, the external circle of the plates of the periproct is very distinct. The plates that form it are notably larger than the interior plates. In the smaller individual, these external plates are not very large. The decrease in size is more progressive in the internal plates.

The photographs that I reproduce here allow me to dispense with a detailed description of the apical system of three three small individuals (Pl. VIII, fig. 4 and 5; Pl. IX, fig. 1).

The pedicellariae, the spines and the spicules of the tube feet have been very well described and figured by Mortensen, with a description to which I shall return. This author has represented the small ventral spines that have denticulations on a good part of their length, but whose end is smooth. This is what happens on most of them, but I note that the length of this smooth region is variable. Sometimes the denticulations continue to near the end. This terminal part itself is often more strongly bent than in the figure of Mortensen. Other times, it continues in a straight line for the rest of the spine. I reproduce here some photographs of these spines (Pl. XXV, fig. 4).

Ch. Granulatum was known up until now in the Gulf of Siam and in the Sunda Archipelago. The dredges of the INVESTIGATOR show that it is found also in the seas of Indian. It is moreover possible that it has a more vast geographical extent because it has sometimes been confused with Astropyga radiata or pulvinata. The species appears to be localized to littoral stations and rarely descends below 100 meters depth. However, the SIBOGA has dredged it at 216 meters at $10^{\circ} 27^{\prime}$ 'S. and $123^{\circ} 28^{\prime}$ E.

\section{Astropyga radiata (Leske)}

Astropyga radiata. Döderlein, 1902, p. 699, pl. LIX, fig. 8. Astropyga radiata. Meijere, 1904, p. 56.

Astropyga radiata. Mortensen, 1904, p. 18, pl. III, fig. 15 and 19; pl. IV, fig. 9 and 17; pl.

V, fig. 27 (bibliography).

Astropyga radiata. A. Agassiz and H. L. Clark, 1908, p. 123.

Astropyga radiata. Rudnose Brown, 1910, p. 23.

Astropyga radiata. Rudnoseo Brown, 1910 a, p. 38.

Astropyga radiata. H. L. Clark, 1923, p. 373.

Terribles. - 13 fms. - One specimen.

Coast of Ganjam - 24- $30 \mathrm{fms}$. — “Golden Crown", 8-16 March 1909. — One specimen.

Gopalpore. - 25-28 fms. — "Golden Crown”, 23-27 September 1909. — One small specimen, dry.

Table Island. — “Golden Crown”, November 1910. — One specimen. 
The specimen of Table Island is in an excellent state of preservation. The diameter of the test is $90 \mathrm{~mm}$. That of the Terribles is a little smaller. The diameter is only $80 \mathrm{~mm}$. The test is a little deteriorated. The specimen from the coast of Ganjam is larger. Its diameter is 11 centimeters. The dorsal surface is nearly completely lacking spines. But the ventral surface has preserved them, Finally, the specimen from Gonalpore, that is only $65 \mathrm{~mm}$ in diameter, has also a denuded dorsal surface, This last individual, that is dry, is a very uniform violet-gray with, however, traces of red bands on the dorsal surface of the test. The three other individuals have a very bright appearance, conforming to that Loriol noted in the specimens from Mauritius.

A. radiata is well studied, especially by Döderlein in 1902 and by Mortensen in 1904. The latter author has in particular described and figured, with his usual talent, the pedicellariae that are so poorly known. The two authors have discussed the distinctive characters of $A$. radiata and pulvinata and established the synonymy of the first species with A. mossambica Peters, elastica Studer and Freudenbergi Sarasin. I can only refer to the memoirs of these two scholars,

$A$, radiata appears fairly well distributed in the equatorial regions of the Indo-Pacific domain. We know it in the African islands, Madagascar, Mauritius, Reunion, Mozambique, on the coast of Kerimba and at Zanzibar, at the Philippines, in the seas of India (Ceylon, Mergui islands, Bay of Bengal) and finally in all the Sunda Archipelago. The indication given by Bell in 1904, on the subject of the existence of this species at the Cape, that this was doubtful has been confirmed by H. L. Clark in 1923.

\section{Centrostephanus nitidus nov. sp.}

(Pl. IX, fig. 4 to 10; Pl. X, fig. 1, 3, 4, 8 and 9; Pl. XXVI, fig. 2)

Station 127. $-13^{\circ} 17^{\prime}$ N.; $93^{\circ} 7^{\prime}$ E. -90 fms. - Several specimens.

The individuals are generally in good condition, but the very long spines are rarely completely preserved.

Among the specimens collected, I mainly looked at three of different dimensions that are in alcohol and four others that have been dried. One of the latter completely lacks spines that allows me to study the characteristics of the test. I have designated these specimens respectively by the letters A to $\mathrm{G}$.

Here are the principal dimensions that I measure on these individuals.

\begin{tabular}{|c|c|c|c|c|c|c|}
\hline Specimen & $\begin{array}{l}\mathrm{A} \\
\mathrm{m}\end{array}$ & $\begin{array}{c}\mathrm{B} \\
\mathrm{mm}\end{array}$ & $\begin{array}{c}\mathrm{C} \\
\mathrm{mm}\end{array}$ & $\begin{array}{c}\mathrm{D} \\
\mathrm{mm}\end{array}$ & $\begin{array}{c}\mathrm{E} \\
\mathrm{mm}\end{array}$ & $\begin{array}{c}\mathrm{F} \\
\mathrm{mm}\end{array}$ \\
\hline Diameter of the test $\ldots . . \ldots \ldots \ldots \ldots \ldots$ & 32. & 30 & 15.5 & 28.5 & 24 & 19. \\
\hline Height,$\ldots \ldots \ldots \ldots \ldots \ldots \ldots \ldots \ldots \ldots$ & 5 & 14 & 8 & 13 & 10 & 5 \\
\hline Length of spines $\ldots . \ldots \ldots \ldots \ldots \ldots \ldots$ & 15 & 34 & 27 & & & 9 \\
\hline Diameter of the apical system ......... & 35 & & & 8.5 & 7 & \\
\hline Diameter of the peristome ........... & & & & 10.5 & 9 & 6 \\
\hline
\end{tabular}


Diameter of the periproct ...............

Width of an ambulacral zone at the

ambitus

Width of an interambulacal zone $\begin{array}{lll}4.6 & 4 & 7\end{array}$

$\begin{array}{ll}6.6 & 3\end{array}$

$\begin{array}{lll}10.5 & 6.6 & 5\end{array}$

87
2.8

4.5

6

The structure of the test has characters that we know in the genus Centrostephanus. We can in particular see the resemblances in comparing the photographs that I reproduce here of $C$. nitidus with the figure of the test of $C$. longispinus that I published in 1895 (pl. IX, fig. 9 and Pl. X, fig. 4). I shall study principally the characters of the test of specimen $\mathrm{D}$ that is the largest of the dry individuals and that lacks its spines (Pl. IX, fig. 9 and Pl. $\mathrm{X}$, fig. 4).The test is very thin and very fragile. It is flat with the dorsal surface nearly plane and the ventral surface rounded. These two surfaces are connected by very rounded sides. The apical system has, as a whole, a rounded contour. The genital plates are large, pentagonal, wider than $\mathrm{v}$, with an obtuse distal corner limited by two straight sides, two straight, slightly divergent lateral borders and whose length is nearly equal to the sides of the distal corner. The wide proximal border is nearly straight. The opening, near the distal corner, is found toward the first third or fourth of the plate. Each plate has in general a small secondary tubercle accompanied by two or three smaller tubercles, Genital 2 is not much larger than the others. It is always a little ver and a little wider. Its distal corner is always extremely obtuse. The gonopore is very near the top of the corner. The madrepore pores placed inside leave free a good part of the proximal region of the plate filled by a principal tubercle. The ocellars have little variable form. They are in principal triangular, wider than long, with a more or less truncated proximal corner. In the specimen that I describe, plates $\mathrm{V}$ and IV have kept their triangular form while the other plates ae truncated on their internal corner. Each ocellar plate has a number varying from one to five very small and little projecting tubercles arranged in the most irregular manner. In general, we can observe between each ocellar plate and the periproct, one or two very small supplementary plates corresponding to those plates that I have described in $C$. longispinus under the name of anal plates and that, in the latter species are much more important than in $C$. nitidus. These plates are fairly apparent in specimen D. I see only a single small plate in ambulacrum II between the ocellar and the periproct. In each of ambulacra III, IV and V, there are two small plates in the form of elongated graniules that extend the length of the sides of the ocellar. Finally, in ambulacrum I, I find a small group of three small plates, one larger median and two smaller laterals.

I shall return a little later to these plates, in studying other individuals in which they are more developed than in specimen D.

The periproct is covered with numerous small plates, very dense and sometimes imbricated, a little unequal. They cover uniformly all the surface of the periproct up to the anus. This is very widely open but does not form a protruding tube.

The peristome has a very sinuous contour. The notches are not very deep, but they are wide, a little wider than deep. In addition, the middle of the ambulacral zone has a notch nearly as wide but less deep, than the adjacent notch. The buccal membrane is thin and transparent. The ten buccal plates are near the mouth. The two plates of each pair form an ovoid group two times wider than long. Toward the border of the peristome, we find, in each interradius, two small plates widened transversely with, among them, some other 
plates of much more reduced dimensions. Each of these plates has a small, little developed tubercle.

The width of the ambulacral zones increases vey regularly from their origin up to the ambitus. They remain limited by nearly straight sides. The first nine or ten ambulacral plates remain simple, very narrow. Each has a pair of pores that occupy more than half of the width. The other half remains bare. After the ninth, or sometimes the tenth, three simple plates are fused. They form major plates in which the pairs of pores are arranged in extremely open arcs. Usually the three simple plates that form the first major plates are incompletely fused. These major plates are large, rectangular, one and a half times wider than long. A good part of their surface that remains free inside the poriferous one is filled by a large primary tubercle, perforated and crenulated. Sometimes, this tubercle is missing on the first and sometimes even the second composite plate. I count in general eleven of these primary tubercles up to the peristome. The first two, located above the ambitus, are very large and unequal. The third, located at the ambitus, is usually slightly smaller than the preceding two. But the dimensions continue to decrease very regularly up to the peristome. Some small secondary tubercles are seen between the primary tubercles and the median suture. In general, each plate ha only one of the small tubercles that are located toward the internal and upper corner. Below the ambitus, these tubercles become smaller and more numerous. Each plate has two or three. Each of the first major plates that still have not acquired the primary tubercles has one of these small secondary tubercles. The crenulation of thee tubercles is very apparent when they are clear of soft tissue (this is not always the case in specimen D that I represent here because I did not dare push too far the cleaning of the test because of its fragility). The poriferous zones are relatively wide, the pores being rather large. The wall that separates the two pores of each pair is very protruding. It is narrower than the diameter of a pore.

The interambulacral plates are large and rectangular. They each have a large primary tubercle, nearer the median suture than the external border of the plate. The first two or three plates of each row lack primary tubercle. They have in general only two or three secondary tubercles. The primary tubercle differs only in their larger size from the corresponding ambulacral tubercle. There are ordinarily twelve of these tubercles in each row. The dimensions remain nearly the same from the first to the fourth that is found at the ambitus. After this, the dimensions decrease slightly. Each tubercle with its scrobicular circle occupies all the height of the plate. Toward the external border of the plates, we see on the fourth or fifth plate of each row, a small secondary tubercle. These secondary tubercles form a regular series whose dimensions increase up to the ambitus, then decease below. This series continues up to the peristome. Some other tubercles, a little small and arranged without order are tall added to the preceding. They ordinarily appear from the second interambulacral plate. Likewise, a second series, usually containing one tubercle per plate, is seen toward the median suture of the plates, at the internal and upper corner. It continues up to the peristome. These tubercles always remain smaller than those of the external series that I reported above.

The tests lacking spines have a variable color. Sometimes it is uniformly gray or pinkish-gray or even greenish. In some specimens where the test is grayish, we can see a pale line along the interambulacral suture with, on each side, a band of dark purple, leaving from each genital plate, that has itself small dots of the same color. A similar band, but less distinct, runs the length the median line of each plate. It happens that the 
dark double line continues on the genital plates in the form of a single line that goes sometimes to the periproct where it becomes very thin and extends even to the center of this system where it forms with the four other similar line a cross with five arms. Elsewhere the test is brownish gray. There is a white line along each ambulacral and interambulacral median suture. The ventral surface is much paler and of a uniform tint.

In the specimens with spines, the dorsal surface of the test is a more or less dark violetgray, while the spines are a uniform very bright red without the least trace of rings in general. The spines are cylindrical, hollow, extremely thin and very fragile. They keep the same width for nearly their entire length. In the largest specimen, the large spines measure 0.4 to $0.5 \mathrm{~mm}$ in width. Their width and length is always greater than the diameter of the test. But they are often broken toward their end. We see by the numbers indicated in the table that the dimensions that I have given above, that the primary spines are relatively larger in the small individuals than in the larger. For example, in the small specimen $\mathrm{C}$, the length of the spines is nearly double the diameter of the test, while in specimen A, this length is only several millimeters greater than the diameter. These spines have the characteristic and well-known structure of the genus Centrostephanus. We recognize very easily with a magnifying glass the successive verticilles formed by dense spinules with the free point that, together, determine the longitudinal striations. These verticilles are separated from each other by a space a little greater than the width of the spine. With the microscope, these verticilles are less apparent. We recognize them only by the strong projections the ends of the spinules make on the sides of the spine ( $\mathrm{Pl}$. XXVI, fig. $2 f$ ). Sometimes the end of the spine is white. More rarely, the spines have toward their end one or two wide white and red rings.

The tube feet have in their walls, spicules with the usual H, V, Y or T forms, or even irregular or branched rods. Sometimes the lateral branches of the spicules unite with each other. This results in the formation of perforated plates, generally elongated and of varying form of variable dimensions (Pl. XXVI, fig. $2 a$ and $b$ ).

The pedicellariae are fairly abundant. There are no less than six forms, two kinds of tridacyles, one very large, the other, smaller; rostrate, globiferous, ophiocephlous and trifoliate (fig. $2 c$ to $j$ ).

The large tridactyl pedicellariae are extremely developed. The length of their head exceeds $2 \mathrm{~mm}$ (fig. $2 \mathrm{c}$ ). They have the usual structure of large tridactyle pedicellariae known in C. longispinus, coronatus Verrill and asteriscus Agassiz and Clark. Their valves are thin and very elongated. The narrow blade keeps a fairy uniform width for nearly all its length. It becomes, however, a little wider toward its end than in the middle. The end is very round and not pointed at all. The basal part of the valve is very short and unimportant as usual. Its length, that is 0.22 to $0.24 \mathrm{~mm}$, scarcely reaches a tenth of the total length of the valve. Its width is $0.3 \mathrm{~mm}$ on average. The edges of the blade have low denticulations, widened at the base triangular and little important, separated by unequal intervals that become less and less developed after the middle of valve to disappear in its last quarter. The perforations are small and unequal, little regular. They form small transverse rows only in the slightly enlarged terminal region of the valves.

There are other tridactyle pedicellariae that are much shorter than the preceding. The head measures approximately $0.4 \mathrm{~mm}$ in length (fig. $2 e$ ). the basal part of the valves, wide and triangular, occupies approximately a third of the total length. The apophysis has two or three round teeth in the lower part. The arcs are little developed. The blade has the 
form of a spoon that widens progressively from the base up to the middle of its length. Then it narrows again up to the end that is pointed. Its borders have round denticulations, unequal and widely spaced. They become stronger and pointed near the end. The perforations from very regular longitudinal and transverse rows.

A third kind of pedicellaria still includes tridatyles that are very similar to the rostrates that we know in irregular echinoids. This form has not yet been reported in the genus Centrostephanus. The head is large. It can exceed $0.8 \mathrm{~mm}$ in length (fig. $2 \mathrm{j}$ ). The valves are thin and narrow, very separated from each other and convergent. The basal part is approximately a quarter of the total length of the valve. It is not very developed. The valves then become very thin. They keep the same width for all their length. They come together at the end by widening very slightly. The edges are smooth. We see some denticulations only on the small contiguous terminal edges of the valves. These denticulations are extremely small and inconspicuous $(g)$.

The globiferous have the usual structure and characteristic well known in the genus Centrostephanus. They have a very small head and three glands on the stalk. The valves are small. They measure 0.25 to $0.28 \mathrm{~mm}$ in length (fig. $2 \mathrm{~h}$ ). They greatly resemble those that Mortensen represented in C. Rodgersi (1904, pl. IV, fig 11). The height of the basal part equals nearly half the total length. Its perforations are very small, numerous and dense. The blade is very narrow. It ends in four to six long and pointed teeth. We see only two or three looking at it in profile as those I represent here. These pedicellariae resemble more those of $C$. Rodgersi than those of $C$. longispinus because of the length of the blade.

The valves of the ophiocephalous pedicellariae have a length varying from 0.26 to $0.30 \mathrm{~mm}$. They resemble those of $C$. longispinus. Their blade is sensibly longer than the basal region. Its edges are very slightly festooned and very finely denticulated. The perforations are small and regularly arranged (fig. $2 d$ ). In some pedicellariae, the length of the head reaches $0.4 \mathrm{~mm}$.

The head of the trifoliates does not exceed $0.2 \mathrm{~mm}$ in length. The blade is elongated and oval. Its length equals nearly twice the basal region (fig. $2 i$ ). It is triangular, fairly narrow at the place where it is contiguous with the blade. The width of the latter increases progressively from its base to the end that is widely rounded. The perforations are small and regularly aligned. The form of the valves differs from that represented by Mortensen in $C$. Rodgersi where the blade has a regularly ellipsoid form.

I have said above that in specimen $\mathrm{D}$ we see, between the ocellar plates and the periproct, one or two small supplementary plates that develop a little larger in other individuals and nearing that which exists in C. longispinus and Rodgersi. I shall recall that in the first species, as I indicated in 1895, the ocellars themselves do not touch the periproct and that they are separated by two small plates or sometimes only one. This plate (or the group of small contiguous plates) has nearly the same width as the ocellar plate and at the same time it separates from each other the two adjacent genital plates. In the specimen that I represented in 1895 (pl. IX, fig. 4), three of the intervals between the genital plates were occupied by only one of these small plates, while the two others each contained two distinct ones. In C. Rodgersi, we can see, in the photograph published by Agassiz in his Revision (pl. III $b$, fig. 1), that there is inside each of ocellar V and IV, a small, narrow rectangular plate, and, inside plate II, a small triangular plate separating the ocellar from the periproct, while the two other ocellars are directly contiguous with the 
latter. Agassiz did not mention this arrangement in his study. This structure does not exist in C. asteriscus Agassiz and Clark. I do not know if it is present in other described species.

Whatever it is, I note in individual $\mathrm{E}$, that there are between each ocellar and the periproct, a small group of very reduced plates. In ambulacrum I, there are two small unequal plates, elongated and very narrow on each side of the larger median plate. In II, there are two unequal and unimportant plates. In III, there are two small, divergent and non-contiguous plates extending the length of the adjacent edges of the ocellars. In IV, the two small plates are contiguous, rectangular and unequal. Finally, in V, we see three small contiguous plates. The median is a little larger than the others (Pl. X, fig. 3 and 8).

In specimen $\mathrm{F}$, a little smaller than the preceding, we can recognize between the ocellar and the periproct, two small supernumerary plates in each of the ambulacra II, I, $\mathrm{V}$ and IV, unequal in the first two. In III, there is only one triangular plate (Pl. IX, fig. 7 and Pl. X, fig. 9).

Finally, in specimen G (Pl. IX, fig. 8), still a little smaller, the interval between successive genital plates is very narrow. But the ocellars are widely separated from the periproct in general. Consequently, from the intercalation of a single small, elongated plate at the proximal part of which we can distinguish an extremely reduced plate in ambulacral I and two in III.

I find similar arrangements in the other individuals, even smaller than the preceding. The ocellar plates are always separated from the periproct at least by one small plate and often two.

When I described the skeleton of $C$. longispinus in 1895, I gave to the small plates the name of anal plates. But I have not wanted to say by that these plates belong to the periproct. To the contrary, it seems to me there is a fragmentation of the ocellar plates. In any case, the small plates in question do not have at all the aspect of the plates that cover the periproct, which are gray and of uniform dimensions. To the contrary, the supernumerary plates are white like the ocellar plates that they follow.

SIMILARITIES AND DIFFERENCES. - By the composition of the skeleton and by the pedicellariae, this species belongs to the genus Centrostephanus. It appears to me especially to be near $C$. longispinius, from which is separated however by the color of is spines that are a very bright red and comparatively longer and finer, by the absence of the white or yellow line on the middle of the ambulacral and interambulacral zones; by the large tridacyle pedicellaria with valves keeping the same width for all their length and even slightly widening in the last part with the round and not pointed end, and finally by the presence of a form of tridacyle pedicellaria similar to the rostrate of the irregulars. The dimensions appear always to be less than those of $C$. longispinus.

C. Rodgersi, from Australia, has very much stronger spines, of a very dark purple violet. It is very different from the species of the Indian Ocean. H. L. Clark wrote, it is true, under the name of $C$. tenuispinus, of another Australian form, more delicate that $C$. Rodgersi. But the color is a brownish red or green and the spines are not very long.

C. asteriscus Agassiz and Clark, from the Hawaiian Islands, differs from our species by the structure of the skeleton, notably by the apical system. It is a small species of very particular appearance, with spines with red and white rings. The large pedicellariae recall those of $C$. nitidus. It has very short tridactyles. 
C. coronatus, from California, also has spines with rings of pale red and dark red. The same spines have rings of white and red in a small species from the Antillles, $C$. rubicingulus recently described by Austin Clark after a single specimen whose diameter was only $12 \mathrm{~mm}$.

\section{Aspidodiadmatidæ}

\section{Aspidodiadema annulatun nov. sp.}

(Pl. XI, fig. 1 to 6)

Invisible Bank. - 16-41 fms. - Three small specimens.

The specimens are of very small size. They are certainly not adults because their gonopores are completely invisible. The diameter of the test does not reach $7 \mathrm{~mm}$ in the largest. It measures only $3 \mathrm{~mm}$ in the smallest. The spines, very long and very fine, are two and a half times greater than the diameter of the test. They are intact in only the small specimen.

Despite their small size, these individuals appear to me to have particular characters that do not refer to species of Aspidodiadema known in the Indian Ocean. I believe that they represent a new species belonging to the genus Aspidodiadema because it does not have large tubercles on the dorsal region of the ambulacral zones.

Here are the principal dimensions that I took on the three specimens that I call respectively $\mathrm{A}, \mathrm{B}$ and $\mathrm{C}$.

\section{Specimens}

Diameter of the test

Height. ....

Diameter of the apical system.

Diameter of the periproct.

Diameter of the peristome.

Maximum length of the large spines

Width of the spines at their base....

\begin{tabular}{lcl}
$\mathrm{A}$ & $\mathrm{B}$ & \multicolumn{1}{c}{$\mathrm{C}$} \\
$\mathrm{mm}$ & $\mathrm{mm}$ & \multicolumn{1}{c}{$\mathrm{mm}$} \\
6.0 & 5.6 & 3 \\
3.2 & 2.5 & 1.5 \\
1.5 & & \\
1 & & \\
1.3 & 2.4 & 1.5 \\
& 15 & 7
\end{tabular}

$\begin{array}{lll}0.3 & 0.2 & 0.15\end{array}$

We can see by these numbers from the table above that the test is little raised and its height does not even reach half of the diameter. All the presently known species attributed to the genus Aspidodiadema have a comparatively much more raised test. Another peculiarity of the specimens is the small dimensions of the apical system whose diameter does not exceed $1.5 \mathrm{~mm}$ in the largest specimen. The ratio between the dimeter of the test and that of the apical system is thus 4.6 in this individual. In no known species is the 
apical system as small in relation to the diameter of the test. The peristome is notably larger.

There is reason to ask if the very small values of the height of the test first, then of the apical system, are not due to the young age of the subjects. This is not probable, but we naturally cannot give a formal confirmation in this regard.

The apical system has the structure known in the genus Aspidodiadema. The genital and ocelllar plates follow regularly in forming a completely smooth narrow ring in which the genitals, wider and rectangular, have the same length as the ocellars that are narrower and square. The ring is a little wider on the side of genital plates 2,1 and 3. The madreporite plate is sensibly larger than the other genitals. In addition, one of the ocellar plates contiguous to the madreporite plate, ocellar II or ocellar III, are not distinct and are without doubt fused to genital 2. The periproct is covered with large and distinct polygonal plates at the periphery but becomes completely indistinct in the central region that appears bare.

The peristome is large. It is covered with imbricated plates, dense, very narrow and strongly widened transversely, with a finely granular surface. These plates cover the entire space between the primary buccal plates and the external border of the peristome, while the narrower internal space appears bare. The primary buccal plates are large and round.

The poriferous area is narrow. The ambulacral zones are extremely small. I count ten primary tubercles on each side. The upper two are very small and remain separated from the apical system.

The color of the test without spines is a pinkish gray. The primary spies are very long and very thin. In the largest specimen, they are all incomplete. In the middle one, the length reaches nearly three times the diameter of the test. These spines have very elegant rings, alternatively white and dark purple. There are ordinarily five white rings and five purple rings, but they are sensibly wider. With the microscope, thee spines appear fairly deeply channeled with verticilles of very fine and very pointed teeth.

I have not found any pedicellariae.

SIMILARITIES AND DIFFERENCES. - As I said above, the three individuals collected by the INVESTIGATOR are obviously very young. They still have not acquired their definitive characters. The description that we can give is obviously incomplete. It is possible that various specifics of the structure they have will be modified with age. Considering only the present arrangement, these three individuals differ from the known species by the small diameter of the apical system, by the genital and ocellar plates that completely lack tubercles and by the flattening of the test. I recall that $A$. nicobaricum has blue-violet or purple spines without rings and the test is brownish-red or purple, that in $A$. tonsum the spines are red or purple without rings, the large spines not numerous and the small spines, to the contrary, very numerous and dense. Finally, in A. Meijerei and Jacobyi, the spines are greenish or green.

\section{Arbaciadæ}




\title{
Pygmacocidaris prionigera (Agassiz)
}

\author{
(Pl. XI, fig. 7 to 9)
}

Podocidaris prionigera. Agassiz, 1881, p. 59, pl. XXXIV, fig. 14 and 15.

Podocidais prionigera. Wood Mason and Alcock, 1891, p. 440.

Podocidaris sp. Meijere, 1904, p. 68, pl. XVI. Fig.243 and 244.

Pygmaocidaris prionigera Döderlein, 1907, p.185; pl. XXII, fig. 2; pl. XXIX, fig. 6; pl. XXXV, fig 4; pl. XLV, fig. 5.

Station $223 .-13^{\circ} 47^{\prime} 30^{\prime \prime}$ N.; $92^{\circ} 36^{\prime}$ E. $-561 \mathrm{fms}$. - A sole specimen.

The diameter of the test is $8 \mathrm{~mm}$. The dorsal surface is completely denuded. The spines remain on the ventral surface but they are all broken.

The diameter of the apical system is a little more than $5 \mathrm{~mm}$. The periproct is $1.8 \mathrm{~mm}$ in diameter.

This species was described for the first time by Agssiz after some specimens collected by the CHALLENGER at Station 205 (16 $42^{\circ}$ ' N.; 119 $22^{\circ}$ E, $\left.1.050 \mathrm{fms}\right)$ and Station 218 ( $2^{\circ} 33^{\prime}$ N.; $144^{\circ} 4^{\prime}$ E, $1,070 \mathrm{fms}$ ), with the name of Podocidais prionigera.

It is probable that this same species was collected by the SIBOGA at Station 54 (Strait of Molo, 19-91 meters) and 266 (5'56' S.; 132 47' E., 595 meters). The specimens measure only 3 and $5 \mathrm{~mm}$ in diameter. We note the very shallow depth of station 51 .

Wood-Mason and Alcock have cited the specimen from station 112 in their work of 1891. But they add that the same species was dredged in 1888 in the Bay of Bengal at 1,590 fms depth. I have not found in the collection that was sent to me any specimen corresponding to this latter indication.

Whatever it is, the species discovered by the CHALLENGER and assigned by Agassiz to the genus Podocidaris was found by the VALDLIVIA at Station 203 in the Strait of Nias at $1^{\circ} 47^{\prime} \mathrm{N}$. and $96^{\circ} 59^{\prime} \mathrm{E}$ at a depth of 660 meters, a little more south, consequently, than the locality where the INVESTIGATOR found the species.

This echinoid cannot be referred in any way to the genus Podocidaris. The creation of a new genus Pygmaeocidaris proposed by Döderlein is perfectly justified. I refer to the work published by this author in 1907 for the characters of the genus Pygmaeocidaris and its relations to the fossil genus Tiarchinus.

The single specimen collected has all the characters of the small individual described very carefully by Döderlein. I note only that, in a profile view, the apical system is very slightly more projecting in the individual of the INVESTIGATOR than that of the VALDIVIA,

As I said above, the spines are all broken. But we recognize, however, in the very short, preserved part of some of them, very developed and pointed teeth that are quite apparent in the photographs of Döderlein. I have found in my specimen only some small ophiocephalous pedicellariae identical to those described by this latter author.

Although very rare, $P$. prionigera appears to have a fairly vast geographic distribution, because it is known in the Bay of Bengal, the Philippines, the Malay Archipelago, the Kei Islands, the Admiralty Islands, etc. at very variable depths, from 69-91 meters to 2,760 meters. 


\section{Coelopleurus vittatus nov. sp.}

(Pl. X, fig. 2, 5, 6, 7 and 10; Pl. XXV, fig 6; Pl. XXVI, fig. 1)

$13^{\circ} 16^{\prime} 30^{\prime}$ N.; $93^{\circ} 08^{\prime}$ E. — 70 fms. - A sole specimen.

The specimen is not in good condition. The test is broken and some of the ventral and lateral surfaces are missing. I have however been able to connect the fragments in a way to obtain some satisfactory photographs.

The contour of the test is round. The diameter is $35 \mathrm{~mm}$ and the height is $21 \mathrm{~mm}$. ventral surface is a little flat. The dorsal surface is a little swollen. The ambulacral zones are fairly projecting and swollen. The interambulacral zones are, to the contrary, completely flat.

The apical system measures nearly $10 \mathrm{~mm}$ in diameter. The genital plates are large and especially very wide. They are contiguous by a small border. The form a continuous ring outside of which is found the ocellars. We can consider thee plates as pentagonal with truncated lateral corners and a proximal border contiguous with the very concave periproct, whose external or distal corner is otbuse. The opening is found located nearly in the middle of the plate, But nearer, however, to the distal corner than the proximal corner. The internal region of these plates is smooth, but the other portion is covered with flat granules, widened transversely, unequal and irregularly arranged, forming a kind of epistroma. The madreporite plate is scarcely larger than the others, with some extremely small openings on the part between the gonopore and the region covered by the epistroma. The ocellar plates have a generally triangular form, with a very obtuse proximal corner limited by two straight borders and a convex distal side. They are longer than wide and covered on their entire surface by a very apparent epistroma. The periproct has the usual constitution. It is covered by four plates arranged in cross. It is very slightly oval and elongated in the direction III-5. It measures $5 \times 5.5 \mathrm{~mm}$ diameter.

The diameter of the peristome is 14 to $15 \mathrm{~mm}$. But these dimensions cannot be measured exactly. The ventral surface of the test being in part bashed in or deformed. It is covered with a thick membrane containing very numerous small plates, delicate, fenestrated, of irregular and unequal form.

The ambulacral zones are large but, however, less wide than the interambulacral zones. They are projecting. Their projection is considerable increased by the large primary tubercles they have that can reach very great dimensions. The ambulacral plates are very large and wide. At the ambitus, they measure $6 \mathrm{~mm}$ in width by a height of $5 \mathrm{~mm}$. Each ambulacral series is formed of twelve plates. The first that follow the ocellar plate is very small. It lacks the primary tubercle. The primary tubercles appear sooner in series $a$ than in series $b$. Plate $2 a$ always has a primary tubercle, while that in series $b$, the tubercles appears only on the fourth plate. The size of the tubercles increases rapidly. The size of these tubercles increases rapidly. The first three tubercles of series $a$, on plates 2, 3 and 4, remain fairly small. The fourth is much larger than the preceding three. The fifth is very large and the same size as the sixth that is found at the ambitus. The seventh is still larger. Then the size decreases greatly on the eighth, and even more rapidly up to the eleventh. 
These tubercles are extremely protruding and thick. Their scrobicular circle is narrow. They are found nearer the median suture than to the opposite border. The external region of the ambulacral plates is filled by the poriferous zones. Each plate has an arc of three pairs of pores. These pairs are widely separated from each other. The median radial region has a few tubercles, flat, a little irregular and unequal, forming a little developed epistroma that does not extend between the successive primary tubercles or on the poriferous zones.

The interambulacral zones are completely flat. This contrasts with the very protruding ambulacral zones. The plates that constitute it alternate very regularly with the ambulacrals and are the same number. They thus have the same length as the latter. But they are wider. At the ambitus, the width of an interambulacral plate reaches nearly a centimeter. The dorsal surface of the interambulacral zones in completely lacking in primary tubercles. The external region of these plates (colored violet as we shall see) is completely smooth. The primary tubercles appear only at the ambitus, both in series $a$ as in series $b$. The first tubercle that appears on plate $b$ is usually a little smaller than the corresponding ambulacral tubercle. The size increases slightly on the following tubercle, then it decreases rapidly on the few successive tubercles of the ventral surface.

The external region of the plates (colored red) has small tubercles, a little unequal and very dense. The internal region, violet, is smooth on the dorsal surface of the test. But, toward the ambitus, it has some extremely flat granules, forming a weakly developed epistroma.

The primary spines are very strong, but they are not very elongated for a Colopleurus. The longest measures $40 \mathrm{~mm}$ in length. This is a number only a little greater than the diameter of the test. They are all truncate at the end, but this truncation does not appear the result of an accident and represents the normal form of the spines. These are never curved but are perfectly straight. They clearly have a triangular form, very elongated with a dorsal crest. The section is an equilateral triangle. The angles of this triangle are distinct in the basal region, then progressively attenuate. But, even in the terminal part, the plate does not become cylindrical. It always keeps the trace of its initial prismatic form. The neck of the primary spines is remarkable elongated. Its length is close to half the length of the spine. This however has great variations, sometimes more, sometimes less. The border between the neck and the region that follow is not always very apparent. Here are some measures I have taken on some spines:

$\begin{array}{lccccccc} & \mathrm{mm} & \mathrm{mm} & \mathrm{mm} & \mathrm{mm} & \mathrm{mm} & \mathrm{mm} & \mathrm{mm} \\ \text { Total length } \ldots \ldots \ldots \ldots \ldots \ldots \ldots \ldots & 36 & 33 & 39 & 35 & 36 & 33 & 35 \\ \text { Length of the neck .................. } & 16 & 22 & 22 & 23 & 22 & 9 & 12\end{array}$

The width of the spines exceeds $2.5 \mathrm{~mm}$ at the base and is near $1 \mathrm{~mm}$ at the end. On the ventral surface, the spines become very small and flat. They end in a slightly rounded truncated region. The secondary spines are small and cylindrical. They are scarcely more than $4 \mathrm{~mm}$ in length.

The pedicellariae are abundant. Thee ae ow principal kinds, the tridactyles nd he ophiocephalous. The tridactyle pedicellariae can reach a considerable size. In some of them the head reaches $2 \mathrm{~mm}$ in length. This head, which is supported by a long peduncle, has three very elongated valves. The basal region, which equals approximately a third of the total length, has the form of an elongated triangle whose maximum width is scarcely 
a sixth of the total length of the valve. The basal region narrows very progressive to continue with the very narrow blade measuring approximately 0.12 to $0.15 \mathrm{~mm}$ in width. It sometime widens a little in its terminal region (Pl. XVI, fig $1 a)$. The mesh of the network of the valves is large and irregular. The internal surface of the valves has a very apparent secondary calcareous network. However, these pedicellariae, even the largest, are very delicate and very fragile. The lower arcs are fairly developed. Similar tridactyl pedicellariae, whose head reaches large dimensions, have already been found in $C$. maculatus Agassiz and Clark and Maillardi Agassiz. In the other tridactyl pedicellariae, the length of the head is smaller and does not exceed 0.8 to $0.9 \mathrm{~mm}$. The blade is relatively a little wider and its length a little greater than that of the basal region (Pl. XXV, fig. $6 a$ ). Finally, there are other smaller tridactyles. The length of their valves varies between 0.8 and $0.4 \mathrm{~mm}$. It is impossible to find a line separating the basal region and the blade in them. The valves are fairly widened and their form is that of a very elongated triangle that has a very round end with lower arcs that are always well developed. These small tridactyles have the same general structure as the large ones (Pl. XXV, fig. $6 b$ ). Finally, in the fourth kind, the valves are thin and relatively elongated, but the length of head does not exceed that of the preceding form (fig. $1 c$ ).

The ophiocephalous pedicellariae have a form a little different on the test and on the buccal membrane. In the pedicellariae on the test (PL. XXV, fig. $6 d$ ), the valves are wide and short. They measure 0.45 in length by 0.35 in width at their base. This a fairly evident narrowing of the valve between the blade and the basal region. The blade has on its round edge, traces of extremely low denticulations, sometimes scarcely apparent, sometimes a little more distinct. It is a little longer than the basal region. The ophiocephalous of the buccal membrane (fig. $6 c$ ) are a little smaller. They are especially narrower than the preceding. The length is approximately twice the width and the height of the basal region is equal to that of the blade. This has on its edge some low and wide, very apparent denticulations.

The spicules of the tube feet are very small. They form branched rods of very irregular form, with a variable number of small, lateral branches. These spicules greatly recall those that have been figured by Mortensen.

The color of the urchin is very bright. The plates of the periproct are reddish gray, surrounded by a narrow brick red circle. The middle of the interambulacral zones is a very bright pale violet with darker patches, elongated transversely and corresponding especially to the upper region of the plates. This part colored in violet widens progressively from the apical system to the ambitus. But it occupies only the median region of the interambulacral zones. It forms a wide band, very clearly limited to the median region of these zones. It has a width of 5.5. $\mathrm{mm}$ at the ambitus and a little above, on both sides of the interradial line. We would at first believe easily that the interambulacral zones correspond exactly to the violet region and that they are very narrow and narrower than the ambulacral zones. But a more careful examinations allows recognition that the external region of the interambulacral zones has a brick red color that spreads a little onto the adjacent ambulacral zones On them, this red color does not pass the external border of the poriferous ones, while the part filled by the large primary tubercles remain gray. Then the red color reappears on the median line of each ambulacral zone, but much attenuated. The ocellar plates are also red in color and the genital plates are violet. Such is the coloration that we see on the dorsal surface of the test above the 
ambitus. Below the ambitus, the violet color of the median part of the interradius disappears fairly abruptly and passes to a bright red color, but only a band whose width is scarcely greater than one millimeter. The lateral parts occupied by the primary tubercles remain gray. The color of the median red band fades progressively on the ventral surface and disappears before reaching the peristome. The same thing happens on the ambulacrals. The red color that marks the sides and their middle attenuates equally and disappears before reaching the peristome.

The dorsal surface has thus a very brilliant and elegant appearance with these alternating bands of red and violet. On the ventral surface, the colors are much more subdued.

The primary spines are green. Their color remains uniform on a good part of their length. In their terminal part, we see red patches usually irregular, but that form on some two or three narrow and irregular rings. The secondary spines are red. The heads of the pedicellariae also are red. The primary spines of the ventral surface are white.

SIMILARITIES AND DIFFERENCES. - The species discovered by the INVESTIGATOR is remarkable for is prismatic spines, thick and relatively short, always rectilinear, more or less truncated at the end and not pointed, with a fairly homogeneous green color sometimes with red patches in the terminal part and a remarkable length of the neck of the spines.

The genus Coelopleurus is presently represented by six species. Five have been known for a more or less long time. These are C. Maillardi (Michelin) that comes from New Guinea Japan, Sumatra and Reunion; C. maculatus Agassiz and Clark (Amboine and Philippines); elegans Bell (New Guinea), floridanus Agassiz (Atlantic); and longicollis Agassiz and Clark (Philippines).

The sixth species, C. interruptus, which comes from the Cape, was described quite recently by H. L. Clark (1923).

The first five species have been classified by H. L. Clark by the presence or absence of patches or rings on the primary spines. In C. Maillardi, elegans and maculatus, these spines have rings or patches, at least at the base, while in C. floridanus and longicollis, they have a uniform color or patches only in their distal part. This is precisely what happens in $C$. vittatus where most of the spines have a fairly uniform green color. This color is very different from that we see in $C$. floridanus where the spines are red and in C. longicollis where they are white, at least on the dorsal surface of the test. The length of the neck has also been used by Clark to separate the species of the genus. The neck is fairly short in $C$. Maillardi where it is $8 \%$ of the total length of the spine and in $C$. maculatus and elegans where it is only $5 \%$ of the total length. In C. floridanus and longicollis, the neck is longer. It can each 10 to $20 \%$ of the total length. We have seen that in $C$. vittatus, the neck is always very long. This length is variable. It can exceed half the length of the spine. I shall add also that in the new species, these primary spines are very thick, relatively short and never curved.

Independently of these differences, it is impossible to confuse the species of the INVESTIGATOR with C. maculatus whose primary spines are very bright green in color with red patches toward the end and has on the median part of the interradial zones, with the dorsal surface of the test, a special ornamentation. In addition, the spines are narrow and 
slightly curved. $C$. longicollis of the Philippines has been separated from C. Maillardi by H. L. Clark. It is the species represented under this name by Agassiz in the Report of the CHALLENGER. The true $C$. Maillardi has ringed spines.

C. elegans of New Guinea was described by Bell under the name of Salmacis ? elegans. It is remarkable for the yellow color of its primary spines. Finally, C. floridanus of the equatorial Atlantic has a pale chocolate color in the interradial zones and yellow or orange in the ambulacral zones.

C. vittatus cannot be confused with any of these species.

C. vittatus is certainly very near the $C$. interruptus that H. L. Clark has recently described after a specimen collected at the Cape (Algoa Bay) at a depth of $30 \mathrm{fms}$. This specimen is a little larger than that of the INVESTIGATOR. The test had a diameter of 43 $\mathrm{mm}$. The individual from the Cape has an appearance very near that of $C$. vittatus as can be confirmed by comparing the photographs that I reproduce here with the photograph of H.L. Clark (pl. XXI, fig. 3). We shall note that in the two species, the spines are very robust and thick, prismatic and relatively short for Coeloplerus. H. L. Clark did not give the length of these spines in his description, but by measuring them in his photographs, I see that the longest is $50 \mathrm{~mm}$ and that they slightly exceed the diameter of the test. But the color is very different in the two species. In C. interruptus, the bare areas of the interradial areas as well as the distal half of the genital plates is brown, with nine or ten irregular transverse bands of a violet color, brighter toward the ambitus than toward the genital plates. Along each of these bare areas runs a wide white line. The ambulacrals are red. The collar region of the spines is green in the proximal part and above. But the distal region, at least in the dorsal ridge, becomes red-purple and passes to red at the end of the spine. The lower surface of the spines is a more or less conspicuous white. These colors are very different from those we see in $C$. vittatus. The two species cannot be confused.

\section{Salenidæ}

Salenia sculpta nov. sp.

(Pl. XI, fig. 10 to 13; Pl. XII, fig. 1, 2 and 10; Pl. XXV, fig. 5)

Station $238 .-13^{\circ} 16^{\prime}$ N.; $93^{\circ} 08^{\prime}$ E. $-74-60 \mathrm{fms}$. — Ten specimens all dried.

The diameter of the test oscillates around 7 to $8 \mathrm{~mm}$. It can reach $9 \mathrm{~mm}$ in an individual. The larges primary spine reaches a length of $80 \mathrm{~mm}$. The test is not very elevated. Its height reaches $5 \mathrm{~mm}$ in an individual whose diameter is $9 \mathrm{~mm}$ and 4.1 in another whose diameter is only $7 \mathrm{~mm}$. The dorsal surface is very flat. The ventral surface is flat, but the peristome is slightly swollen. The sides are very convex.

The species is very near $S$. cincta Agassiz and Clark. In the description that follows, I shall note especially the differences that separate this latter species from the INVESTIGATOR. 
Here first are some measures that I take on three specimens lacking spines that I shall call A, B and C. and two other intact ones (D and E).

\begin{tabular}{|c|c|c|c|c|c|}
\hline Specimen & $\begin{array}{c}\mathrm{A} \\
\mathrm{mm}\end{array}$ & $\begin{array}{c}\mathrm{B} \\
\mathrm{mm}\end{array}$ & $\begin{array}{c}\mathrm{C} \\
\mathrm{mm}\end{array}$ & $\begin{array}{c}\mathrm{D} \\
\mathrm{mm}\end{array}$ & $\begin{array}{c}\mathrm{E} \\
\mathrm{mm}\end{array}$ \\
\hline Diameter of the test $\ldots \ldots \ldots \ldots \ldots \ldots \ldots$ & 8 & 7 & 7 & 8 & 6.5 \\
\hline Height of the test $\ldots \ldots \ldots \ldots \ldots \ldots \ldots \ldots$ & 5 & 14 & 4.5 & & \\
\hline Diameter of the apical system ........... & 4.2 & 4 & 3.7 & & \\
\hline Diameter of the periproct...$\ldots \ldots \ldots \ldots$ & $1.5 \times 1.4$ & $1.4 \mathrm{X} 1.3$ & $1.3 \mathrm{X} 1.2$ & & \\
\hline Diameter of the peristome ........... & 3.6 & 3 & 3 & & \\
\hline Length of the longest spines ......... & & & & 30 & 30 \\
\hline Width of the longest spines ........... & & & & 0.6 & 0.6 \\
\hline Length of the secondary spines ........ & & & & 0.9 & 1 \\
\hline Maximum width of the secondary & & & & & \\
\hline spines $\ldots \ldots \ldots \ldots \ldots \ldots \ldots \ldots \ldots$ & & & & 0.8 & 0.7 \\
\hline
\end{tabular}

We see by the preceding numbers that the diameter of the apical system is sighter greater than half the diameter of the test. This system is vey remarkable by the extremely projecting border that forms the ocelllar plates on the two proximal sides. Each of these borders are swollen in a kind of large flange, irregular and irregularly notched. Similar structures exist in S. cincta of Japan, described by Agassiz and Clark, but in S. sculpta, the proximal angle of the ocellar plates is much more obtuse than in S. cincta. In the latter species, Agassiz and Clark could have said that the swollen border formed a kind of horseshoe. To judge from the figure given by the American authors (1908, pl. LII, fig. 9), the proximal angle of the ocellar plate is approximately $60^{\circ}$, while in $S$. sculpta, this angle is very obtuse. It is always greater than $90^{\circ}$ and can reach up to $140^{\circ}$. The ocellar plates are extremely wide and at least four times wider than high. Their central region forms a kind of small projecting button. The genital plates are high, two times higher than wide, of an hexagonal form. They are comparatively higher and narrower than in S. cincta where heir form is heptagonal, due to the fact that the external border is separated into two distinct small sides. Here the external border is simply round and besides it is sensibly narrower than in $S$. cinca, the two lateral sides of plates more toward each other in $S$. sculpta than in the latter species. On the other hand, the genital plates have a special structure on their surface due to the presence of deep depressions separating the strongly swollen regions. Most of these depressions, numbering four or five, are transverse or oblique on each side of the middle of the plate. Then, toward its end, is an elongated median depression separating two equally elongated ridges. It is at the base of this median depression that is found the opening of each plate. The suranal plate, much wider than high has a similar structure Finally the internal border of the four plates that limit the periproct, forms around the latter a thick and projecting border that encircles it. The periproct itself is irregularly circle. It often has the form of an enlarged triangle with very rounded borders. It is covered with numerous polygonal or triangular plates that become very small in the center. The large peripheral plates each has a small tubercle.

The structure of the genital plates that I just indicated recall those that Agassiz and Clark have described and figured in Salenocidaris crassispina (1908, p. 61, pl. LII, fig. 2 ). To the contrary, in S. cincta, the genital plates and the suranal plates ae simply covered 
by a fine granulation according to Agassiz and Clark. The peristome is smaller than the apical system. It is covered with large, imbricated plates, triangular or lozenge-shaped, widened transversely, among which the ten primary plates are distinguished by their size and pentagonal contour.

I do not see that the structure of the corona of S. sculpta differs from that we know in $S$. cincta. The primary ambulacral tubercles follow each other very regularly and each corresponds to two pairs of pores.

The test lacking the large spines is simply grayish, sometimes a slightly pinkish gray. The apical system is very often a little deeper than the rest. The thickenings of the proximal border of the ocellar plates are a more or less dark brown.

The primary spines are extremely long and thin. They are straight or very slightly curved. But this curvature, when it exists, is seen the entire length of the spine and not toward its end only. These spines have a white, slightly yellowish tint with wide purple rings. These rings number approximately a half dozen per spine. They are thus much less numerous than in S. cincta where, according to Agassiz and Clark, the color is a dull red. The secondary spines have the well-known form. They are flat in the form of a triangle, sometimes wide, sometimes thin, with a truncated and somewhat rounded base. I represent here some of these spines in $\mathrm{Pl}$. XXV, fig. $5 c$.

I have encountered only a very small number of pedicellariae belonging only to the tridactyl and ophiocephalous forms. The head of the tridactyls measues 0.12 to $0.14 \mathrm{~mm}$. The valves are similar to those that Agassiz and Clark have figured in $S$. cincta $(1908, \mathrm{Pl}$. VL, fig. 23). The ophiocephalous pedicellariae are a little smaller. The length of their head varies between 0.1 to $0.12 \mathrm{~mm}$ (Pl. XXV, fig. $5 a$ and $b$ ). I have not encountered globiferous pedicellariae that were indicated by Agassiz and Clark in S. cincta. The sphaeridia are ovoid, a little wider than long, instead of being nearly spherical as in this latter species.

SIMILARITIES AND DIFFERENCES. - As I have said above, S. sculpta is near S. cincta. The differences that separate them are indicate in the preceding description that is especially comparative. They basically have to do with the characters of the apical system, the special structure of the genital and suranal plates, the enlargement of the ocellar plates bordered by a widening forming a very a very obtuse angle, and finally by the length and small number of rings on the primary spines. In addition, the apical system doe not special coloration. It remains grayish or brownish gray, of a darker tint than the rest of the test, while it is purple in $S$. cincta. I shall recall for the record that the apical system, in addition to being larger in S. Pattersoni, is violet and that it is, to the contrary, smaller in $S$. phoïnissa Agassiz and Clark whose test is white with dark red or violet coloration.

The other species previously attributed to the genus Salenia belong to the genus Salenocidaris whose ambulacral plates are simple instead of being composed as in the genus Salenia. Our species cannot be referred to it.

\section{Pedinidæ}




\section{Cœnopedina depressa nov. sp.}

(Pl. XII, fig. 7, 8 and 9)

7¹7’30” N.; 7654’ E; — 430 fms. — A single specimen.

The specimen is certainly immature because no gonopore is apparent. The spines are partly removed. The large spines are all broken a short distance from their base. The largest have preserved scarcely a length of $7 \mathrm{~mm}$.

As it is a matter of a young individual, it is very difficult to have a very exact idea of its characters. However, I cannot relate it to any known species. In particular, it appears to me to differ from $C$. indica that Meijere has described after an individual from the Sunda Islands coming from a depth of 884 meters. In fact, the individual collected by the INVESTIGATOR is notable for a considerable flattening of the test. Its height does not even reach half its diameter, while in the individual of Meijere, the ratio between the diameter and the height is nearly 1.6. C. indica is distinguished in fact from the other species of the genus by its remarkably elevated test. I do not believe, on the other hand, for reasons I shall indicate later, that the individual of the INVESTIGATOR can be related to one of these latter species. With these conditions, and although the specimen is immature, it appears good to me to indicate briefly its characters and apply to it a name that indicates the remarkable flatness of the test.

Here are the principal dimensions that I have taken on this individual:

Diameter of the test. .......................................... $\quad \begin{aligned} & \mathrm{mm} \\ & 11.5\end{aligned}$

Height of the test. ............................................... 5.8

Diameter of the peristome. .......................................... 5.7

Diameter of the apical system between the top of a genital plate and the 6.2

border of the opposite ocellar.

Diameter of the periproct. ........................................ 2.3

The apical system is very large. Its diameter reaches $6.2 \mathrm{~mm}$, or more than half the diameter of the test. The genital plates are very large and high, pentagonal, with a very obtuse and round distal corner, and a convex proximal edge. They are largely contiguous, a little wider than high. The surface of these plates Is nearly smooth. We see only some very small miliary tubercles. I have said above that there is not the least trace of gonopores. The ocellars ae not very large in relation to the genitals. They are pentagonal with an obtuse proximal corner. The sides are widely divergent, wider than high.

The opening is very distinct on each of them and is near the distal edge. The periproct is circular and a little irregular. It is covered with small plates, irregular, numerous and very unequal.

The peristome reaches nearly the diameter of the apical system. It is however very slightly smaller. Independently of the ten primary buccal plates, the peristomial membrane has some very small, isolated plates that have, like the primary plates, ophiocephalous pedicellariae. 
The ambulacral areas are moderately widened. The poriferous zones are very narrow and have arcs of three pairs, very close to each other, and forming a nearly straight line. The primary tubercles do not reach the apical system. They stop at some distance from this system. The two primary tubercles are very small. We can count six to seven primary tubercles in each series.

The interambulacral plates are very large and high. The primary tubercles are very developed. The tubercle nearest the apical system is the most developed because the dimensions of the tubercles decrease progressively to the peristome. We can count six in each series.

The primary spines are all broken so that it is impossible to have an idea of the appearance of the living urchin. These spines measure 0.25 to $0.3 \mathrm{~mm}$ in width at their base. They have on their surface small, very regular channels with very fine asperities. Their color is very pale, nearly white. We can however recognize some very distinct traces of rings.

I have encountered two kinds of pedicellariae: ophiocephalous and globiferous that resemble those of $C$. indica. The valves of the ophiocephalous hardly reach $0.2 \mathrm{~mm}$ in length or remain a littler shorter. The valves of the globiferous are also $0.2 \mathrm{~mm}$. They end in two divergent hooks.

The color of the specimen in alcohol is very pale yellowish white.

SIMILARITIES AND DIFFERENCES. - The species of the genus Conopedina presently known number five: $C$. cubensis from the Antilles, indica from the Kei Islands, hawaiensis and pulchella from the Hawaiian Islands, and mirabilis from Japan. The specimen of the ALBATROSS is separated immediately, as we have seen, by its flat form from $C$. indica Meijere that has a much more elevated test and from $C$. mirabilis that has extremely developed buccal plates. $C$. hawaiensis has a clearly violet dorsal region of the test and very developed tridactyle pedicellariae, while $C$. pulchella has only a small number of plates on the periproct. There can be no question of relating $C$. depressa to $C$. cubensis of the Atlantic.

\section{Temnopleuridæ}

\section{Temnopleurus toreumaticus (Klein)}

(Pl. XIII, fig. 14 to 17 and Pl. XIV, fig. 1 and 2)

See for the bibliography:

Temnopleurus toreumaticus. Mortensen, 1904, p. 58, pl. VI, fig. 8, 14, 22 and 49; pl. VII,

fig. 3 and 28.

Temnopleurus toreumaticus. Hume, 1906, p. 136.

Temnopleurus toreumaticus. Tokunaga, 1906, part 2.

Temnopleurus toreumaticus. Agassiz and Clark, 1907, p. 125.

Temnopleurus toreumaticus. H. L. Clark, p. 304.

Temnopleurus toreumaticus. Döderlein, 1911, p. 244. 
Temnopleurus toreumaticus. H. L. Clark, 1912. p. 312.

Temnopleurus toreumaticus. H. L. Clark, 1923, p. 382.

Station 27. - Coast of Orissa; Black Pagodes. - 11 fms. - 15 December 1889. - Several specimens of very small size.

Station 47. - Mouth of the Godavari (Sacremento Mouth). — 6 fms. - 29 March 1889. - Three small specimens.

Station 88. - Coast of Vizigapatan. - 7-8 fms. - A fairly small specimen.

Station 99. Coast of Vizigapatan. - $23 \mathrm{fms}$. - A fairly small specimen.

Coast of Orissa. - $11 \mathrm{fms}$. - Six very small specimens.

Coast of Orissa. - 6-10 fms. - Very numerous small specimens.

Coast of Orissa, Kundapa. - $7 \frac{1}{2} 2 \mathrm{fms}$. - 18 December 1888. - A specimen whose test is $22 \mathrm{~mm}$ in diameter.

Coast of Puri. - Several specimens in which the diameters vary between 8 and $15 \mathrm{~mm}$.

Coast of Puri, "Golden Crown". - October 1908. Several specimens in which the diameter varies around $15 \mathrm{~mm}$.

$31 \frac{1}{2}$ miles E. S. E. of Puri. - $10 \mathrm{fms}$. - Five specimens of average dimensions.

Gulf of Martaban. - $6 \mathrm{fms}$. - One specimen of average size.

S. W. of Cape Comorin. - $9 \mathrm{fms}$. - A large dry specimen whose diameter is $34 \mathrm{~mm}$.

Diamond Island. - $6 \mathrm{fms}$. - 15 March 1876 - Numerous specimens whose diameter varies around 15 $\mathrm{mm}$.

South of Ceylon. $-6^{\circ} 01^{\prime}$ N.; $81^{\circ} 16^{\prime}$ E. -34 fms. - Two small specimens.

Andaman Islands. (Wood-Mason). - A half-dozen small specimens.

Andaman Islands. - $20 \mathrm{fms}$. - Three small specimens.

Chebuda (coast of Arrakan). - One fairly small specimen.

Mergui Archipelago. - A half-dozen small specimens.

North end of Persian Gulf. - A dozen specimens of variable size. The two largest reach 27-28 $\mathrm{mm}$ in diameter. The smallest does not reach $12 \mathrm{~mm}$.

Arrakan Coast. - A fairly small specimen.

Ye Burmah. - One specimen (diameter $17 \mathrm{~mm}$ ).

One mile to the east of Terribles. - Six specimens who diameter varies between 14 and $22 \mathrm{~mm}$.

Andaman Islands. - Eight specimens whose diameter varies between 9 and $25 \mathrm{~mm}$.

Without locality. - Numerous specimens, nearly all small, one of them however is $20 \mathrm{~mm}$.

Temnopleurus toreumaticus is a very widespread species, principally in the seas of Asia. Its characters were very well established by Agassiz, then by Döderlein and Mortensen. The latter author in particular completed the information that we have on the pedicellariae. He has shown that the echinoids referred to T. toreumaticus by Sladen in 1878, J. Bell in 1884 and Meijere in 1904 actually belong to different species. The echinoid of Sladen is a Temnotrema sculptum and that of Meijere is probably a Salmacis. It was especially important to confirm the determination of the form Bell referred to $T$. toreumaticus. His specimen came from Port Darwin and T. toreumaticus was absolutely unknown on the coasts of Australia. Mortensen was convinced by examination of the echinoid of Bell at the British Museum that it was a completely different form. On the other hand, Mortensen has insisted on the importance for identification of the species of the rings of the spines that is absolutely constant and completely characteristic of $T$. toreumaticius.

However, in the specimens from Arrakan and in those from Ya Burmah, the spines do not have apparent rings. Their proximal half is white and the distal half is a more or less distinct violet-purple. The specimens from east of Terribles have spines that are nearly completely discolored, but they show some traces of color similar to that of the preceding. 
Finally, the specimens from the Andaman Islands some barely apparent indications of violet and white rings. All these individuals have must have had accidental discoloration.

I have nothing to add to the descriptions of the authors on T. toreumaticus. I shall content myself to give here two photographs of a specimen in part lacking its spines (Pl. XIV, fig. 1 and 2).

I also give some photographs of the apical system of various specimens with successive stages of development, from a very young individual whose test is only $8 \mathrm{~mm}$ in diameter, to show the modifications that the system undergoes as it increases in size (Pl. XIII, fig. 14 to 17). We know that the periproct of $T$. toreumaticus is covered with unequal plates, among which we note one plate larger than the others. This plate is much more apparent and the difference in size is much more marked in the young than in the adults. This anal plate has the form of a triangle with a very round top and a base contiguous with the edge of the periproct. It is located opposite interradius 3 or nearly opposite this interradius. This location appears to be absolutely constant. At least, I have never seen this plate in any other position. In the young, the other plates are not very numerous and are of variable size. We can see specimens in which two other plates are distinguished by their size, without reaching however, the dimensions of the true anal plate. As the animal grows, the difference between the plates decreases, but we can always recognize a larger plate and, at its side, three or four others a little smaller and, finally, a variable number of much smaller plates

T. toreumaticus is a particularly Asiatic species that is distributed in the seas of Japan and China, on the coasts of Siam, in the Bay of Bengal and the Persian Gulf, etc. Its presence in the Sunda Islands is not proven because the individual referred by Meijere to T. toreumaticus belongs to another species.

In contrast, the presence of $T$. toreumaticus at the Cape is certain. This is quite surprising. The species was reported in 1899 and H. L. Clark has two authentic specimens coming from Delagoa Bay, so that the presence of T. toreumaticus at the southern end of Africa cannot now be doubted.

\section{Salmacis bicolor Agassiz}

(Pl. XIII, fig. 1 to 4 and 6 to 11 )

See for the bibliography:

Salmacis bicolor. Döderlein, 1902, p. 715; pl. LXIII, fig. 5.

Salmacis bicolor. Mortensen, 1904, p. 65; pl. VI, fig. 2, 4, 23, 26, 39 and 40; pl. VII, fig. 1.

Salmacis bicolor. Rudmose Brown, 1910 a, p. 40.

Salmacis bicolor. Rudmose Brown, 1910, p. 24.

Salmacis bicolor. H. L. Clark, 1912, p. 316.

Salmacis bicolor. H. L. Clark, 1923, p. 382.

Salmacis bicolor. H. L. Clark, 1924, p. 5.

Colombo. - 23 October 1897. - Several specimens.

A half-mile to the south of Cape Comorin - Four specimens. 
Great West Torres. — 9 fms. - One specimen.

Tuticorin. - One specimen.

Mergui Archipelago. - One specimen.

Coast of Orissa. — $20 \mathrm{fms}$. - 2 February 1909. — "Golden Crown". — One specimen.

Coast of Orissa; Black Pagoda. — 15 fms. - One dry specimen.

Gopalpore. - 25-28 fms. - 23-27 September. — "Golden Crown". — One specimen.

The specimens collected are all of large size. The diameter of the test can equal or even surpass $50 \mathrm{~mm}$.

This species has been so well studied by Döderlein and Mortensen that I have little to add to the descriptions of these two scholars. I shall make, however, some remarks on the subject of the sutural corner pores of the middle of the radial and interradial zones, and of the very small pores that are found on the vertical edge of the ambulacral plates, between the ambulacral and interambulacrals. In principle, there is at each sutural corner of the ambulacral and interambulacral plates very small pores, round and keeping the same characters on all the test. Sometimes the pores are extremely small but we can always recognize them. In some specimens of the Indian Museum, they become larger. This is what happens, for example, in the individual that I shall call D and that is represented in Pl. XIII, fig. 2 and 3, where all the sutural pores remain very large. In specimen A, we see curious differences in the pores of the mediain interradial sutures (fig. 6 to 11). In interradius 1 , these pores are quite small and round with however, a tendency to elongated vertically. In interradius 2 (fig. 7), the first pores are round and very fine. Then they elongate in the dorsal middle region of the interradius. They even separate into two small confluent pores. At the ambitus, they become, again very small and single. In interradius 3 (fig. 9), the pores have similar characters, but they are larger and the suture is a little sunken at the beginning of the interradius. Then the pores become identical to those of the preceding interradius, to become again very small and very fine at the ambitus. In interradius 4, the median suture is wide and sunken. The pores are larger for a good part of the length of the interradius, while in interradius 5 (fig. 10), this manifestation is only on a fairly short part of the dorsal surface.

The small pores that can be seen on the vertical suture separating the ambulacral and interambulacral zones are equally irregular and not constant. In some individuals even, they are completely missing. In specimen A (fig. 6 and 7), they are seen in a regular manner, but they are extremely small. In specimen B, they are more apparent (fig. 1). In specimen D where, as we have seen, the sutural pores are very large, these vertical pores are likewise very developed and some of them nearly equal the size of the adjacent tube foot pores (fig. 2 and 3).

We know that the geographic distribution of S. bicolor is quite extended. The species is in fact known at Ceylon, in the Mergui Archipelago at Siam, at Mauritius, and at Mozambique. Finally, H. L. Clark has reported it at the Cape.

\section{Salmacis rarispina Agassiz}

(Pl. XIII, fig. 12 and 13) 
See for the bibliography:

Salmacis rarispina. Döderlein, 1902, p. 179; pl. LXIV, fig. 3.

Salmacis rarispina. Meijere, 1904, p. 83; pl. V, fig. 40.

Salmacis bicolor var. rarispina. Mortensen, 1904, p. 65; pl. VI, fig. 2, 4, 23, 26, 39 and 40; pl. VII, fig. 4.

Non Salmacis rarispina. Loriol, 1893, p. 370 (It is S. sphœroïdes).

Arrakan. - Four specimens.

The specimens are all dry but in good condition. They do not reach a large size. In the largest, the diameter of the test does not pass $27 \mathrm{~mm}$. The others are a little smaller.

These individuals correspond well to the excellent description of Döderlein completed by Mortensen. The largest spines are greenish white with very clear purple rings. The small spines are red.

The sutural pores are well developed in the middle of the radial and interradial zones. At the limit of the ambulacral and interambulacral plates, there is always a vertical series of very fine small pores to the number of two or three, sometimes even four, independent of the slightly larger corner pores (Pl. XIII, fig. 12 and 13).

I have found only ophiocephalous pedicellariae and small tridactyles on my specimens. I recall that Mortensen, who has been able to study specimens larger than mine, saw that the pedicellariae were identical to those of $S$. bicolor.

Like most of the other authors, Agassiz, Bell, Studer, etc., Döderlein has considered that $S$. rarispina is an independent species, while Mortensen made this form a variety of S. bicolor. Döderlein recognized moreover that the two forms are very close. As the specimens of S. rarispina that I have seen are all fairly small, I am not able to contribute to this discussion that is of great importance.

We know that $S$. rarispina has been reported at Mauritius, Ceylon and at the Sunda Islands.

\section{Salmacis virgulata Agassiz}

See for the bibliography:

Salmacis virgulata Agassiz, forma typica. Döderlein, 1902, p. 713; pl. LXII, fig. 1 to 7.

Salmacis virgulata Agassiz, forma typica. Mortensen, 1904, p. 69; pl. VI, fig. 7, 18, 46 and 47; pl. VII, fig. 40.

Salmacias virgulata. Meijere, 1904, p. 83; pl. XVII. Fig. 273.

Salmacisi sulcate. Rudmose Brown, 1910, p. 25.

Two to three miles from Trinehondor Pagoda. $-5-6 \mathrm{fms}$. - Numerous specimens.

Palk Strait. — Several specimens.

Coast south of Ceylon. - One specimen.

All the specimens are of small size, especially those of Palk Strait where the diameter varies between 5 and $9 \mathrm{~mm}$. Those of Trinchondor are a little larger. Their diameter is 
between 9 and $17 \mathrm{~mm}$. Finally, the diameter of the test of the specimen from the south cost of Ceylon measures $12 \mathrm{~mm}$.

These specimens all have the same appearance. The test is gray and the spines are more or less dark violet, passing sometimes to purple violet. Sometimes they are colored over all their length, but most often they are white at the base and their end can also be colorless. We know that $S$. virgulata is the only species of the genus Salmacis in which the spines do not have rings.

I have compared these specimens with other Salmacis virgulata of large size that I have in my collection that come from Singapore. I have been able to convince myself that they belong to the same species.

The characters of the test of $S$. virgulata have been well indicated by Döderlein and those of the pedicellariae by Mortensen. I have nothing to add to the observations of these two scholars.

Several authors, like Döderlein and Mortensen, agree to consider S. Alexandri, mainly known in Australia and New Zealand, as a variety of S. virgulata. H. L. Clark, to the contrary, considers $S$. Alexandri as a distinct species.

Under the typical form, S. virgulata has mainly been encountered at Ceylon, Mergui Islands, Singapore, Java, Macassar, etc. It is to this species that we must refer the Salmacis called sulcata by Duncan and Sladen (1888), by Sluiter (1889) and by Bedford (1900). I think also that the $S$. sulcata coming from the Mergui Islands, reported by R. Brown, is likewise a $S$. virgulata.

\section{Salmacis Dussumieri Agassiz}

(Pl. XII, fig. 11, Pl. XIII, fig. 5)

See for the bibliography:

Salmacis Dussumieri. Döderlein, 1902, p. 715; pl. LXIII, fig. 5.

Salmacis Dussumieri. Mortensen, 1904, p. 72; pl. VII, fig. 15.

Salmacis Dussumieri. Rudmose Brown, 1910, p. 24.

Salmacis Dussumieri. Rudmose Brown, 1910 a, p. 40.

Salmacis Dussumieri. H. Clark, 1912, p. 316; 1924, p. 6; 1925, p. 85.

Station 59- Coast of Ceylon. - 32 fms. - Five specimens whose diameter is between 32 and $18 \mathrm{~mm}$.

Coast of Ceylon. - 26 1 $12 \mathrm{fms}$. - Two average specimens.

$6^{\circ} 04^{\prime}$ N.; $81^{\circ} 16^{\prime}$ E. — 34 fms. — Several fairly small specimens.

Coast of Ganjam. - $101 \frac{1}{2} \mathrm{fms}$. - One specimen whose diameter is $35 \mathrm{~mm}$.

8 miles south of Puri. - A half dozen specimens whose diameter varies between 12 and $32 \mathrm{~mm}$.

Sept Pagodes. - 5-10 fms. - Two small specimens.

One mile east of Terribles. - $13 \mathrm{fms}$. - Three specimens whose diameter is between 11 and $25 \mathrm{~mm}$.

S. Dussumieri occupies a special place in the genus Salmacis. It is immediately distinguished from the other species of the genus by several very pronounced characters. It is by far the easiest species to recognize. Mortensen and Döderlein have already called attention to these characters. First is the flattening of the test. Then the sinking of the 
peristome and the diameter of the periproct. Finally, the alternation in the ambulacral zones of sequential plates with and without primary tubercles.

The flattening of the test makes this species immediately recognizable at first glance. In a large specimen from Port Jackson that I have in my collection, the test has a diameter of $48 \mathrm{~mm}$ and the height is $21,5 \mathrm{~mm}$, the ratio is 2.2 . In the various specimens of the INVESTIGATOR, the value of this ratio is always near 2. Only one specimen from station 50, otherwise identical to the others, has a diameter of $30 \mathrm{~mm}$ and a test height of $17 \mathrm{~mm}$, the ratio falls to 1.6. This individual, seen in profile, is clearly conical, while in the others, the dorsal surface of the test remains regularly convex.

We know that the sutural pores are very apparent in S. Dussumieri. I have always found them extremely developed. The vertical pores along the sutures, between the ambulacral and interambulacral plates, are also very developed and very numerous. In the large specimen from Australia cited above, these pores number six at the fifth interambulacral plate. They have nearly the same dimensions as the adjacent tube-feet pores. I represent in Pl. XIII, fig. 5, a portion of the ambulacral zone of this specimen.

The photographs that I reproduce in Pl. XII, fig. 11, of the individual from Australia, joined to those that Döderleini published in 1902 (pl. LXIII, fig. 5) give a good idea of $S$. Dussumieri.

In the specimens of the INVESTIGATOR, the test is always very pale and the spines are ringed white and dark. The color varies between purple-brown and purple, or violetpurple.

S. Dussumieri has been encountered in a fairly large number of localities in the Indian and Pacific Oceans: Bay of Bengal, Mergui Archipelago, Ceylon, Singapore, Sunda Islands, Cape, Mozambique, Zanzibar, and Australia. Mortenson has reported a specimen from Zanzibar that differs from the type by its color and H. L. Clark has proposed to make a special species that he calls $S$. erythracis for another specimen also from Zanzibar,

The presence of this species at the Cape is not surprising because it was already known in the region of Mozambique.

\section{Salmacis roseo-viridis nov. sp.}

\section{(Pl. XII, fig 3 to 6; Pl. XXVI, fig. 3)}

Terribles. - 13 fms. - Two specimens.

Colombo. - 20 October 1897. One specimen associated with Salmacis bicolor.

The specimen from Colombo, in alcohol, has preserved all its spines. The test measures $43 \mathrm{~mm}$ in diameter. The two spcimens from Terribles are dry. In one of them, the larger, the diameter is $48 \mathrm{~mm}$ and in the second, it is only 36.5. The latter is completely bare, but the first individual has preserved most of its spines. I have removed the spines from a portion. It mainly after this individual that the following description was established.

Here are the principal dimensions that I have taken from the two dry specimens that I shall call respectively $\mathrm{A}$ and $\mathrm{B}$. 


\begin{tabular}{|c|c|c|}
\hline & $\mathrm{mm}$ & $\mathrm{mm}$ \\
\hline Diameter of the test.. & 48 & 36.5 \\
\hline Height of the test .................. & 27 & 21 \\
\hline Diameter of the apical system ...... & 10 & 6.7 \\
\hline 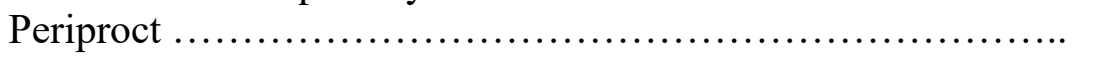 & $5 \times 4.5$ & $4 X 3.6$ \\
\hline 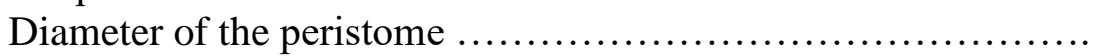 & 11 & 10 \\
\hline Width of an ambulacral zone at the ambitus .................,, & 12 & 9 \\
\hline Width of an interambulacral zone at the ambitus $\ldots \ldots \ldots \ldots \ldots \ldots$ & 20 & 15 \\
\hline
\end{tabular}

The test is quite high and the ratio between the diameter and the height is slightly less than 1.6 in the smaller specimen and 1.8 in the larger. However, in the latter, the profile of the dorsal surface is more rounded than in the small specimen that, seen in profile, is rather conical. The ventral surface is completely flat. The peristome is a little sunken, but in a less distinct manner than in S. Dussumieri. The peristome is remarkable small in specimen A where the ratio between the diameter of the test and the diameter of the peristome exceeds 4. It is comparatively larger in specimen B where the ratio is only 3.6.

The apical system is of average dimensions. The five genital plates have a heptagonal form. The madreporite is a little larger than the others. These plates are wider than high. They each have three principal tubercles toward the proximal edge, plus smaller tubercles on the rest of the surface. The opening is near the top is round. The ocellars are small, pentagonal, with the distal edge rounded and narrowed. They are also longer than high, or very slightly higher than wide.

The ambulacral plates are high. At the ambitus, they are nearly three times wider than high and their width is $7 \mathrm{~mm}$, while their height exceeds $2 \mathrm{~mm}$. The poriferous zones are fairly wide, but the pores are away from the external border of the ambulacrum. The external or lower pair is separated from its border by a space whose width nearly equals a pair of pores. The primary tubercles succeed each other very regularly, only one on each plate, in forming a row very near the poriferous zone that leaves the middle of the ambulacrum absolutely bare. Then, toward the two-thirds of the space that separates the apical system from the ambitus, appears a second series near the radial median line whose tubercles have the same horizontal alignment as the others. The interambulacral plates are high and large. At the ambitus, they are nearly 1 centimeter in width and $2.5 \mathrm{~mm}$ in height. The first seven plates on each side, after the apical system, have only a single primary tubercle each. The tubercles form a principal series that is found nearer the external border of the interradius than the median suture. Two other series appear near the seventh plate, one inside and the other outside the preceding. Finally, a fourth series near the median interradial suture is seen at the ambitus. The interambulacral plates are approximately one third higher than the ambulacral plates. Three interambulacral plates correspond ordinarily to four ambulacral plates.

Outside the primary tubercles, the surface of the interambulacral plates, as well as the ambulacral plates, is nearly completely bare. We only see some very spaced and very fine tubercles. In the ambulacral and interambulacral zones, the tubercles of the principal series are not much larger than those of the other series.

The diameter of these tubercles is much smaller than the height of the corresponding plate. As a result, the part of the plates free of the tubercles is very large, much larger in particular than in S. bicolor. 
The surface of the coronal plates generally has a greenish tint, nearly identical in the ambulacral and the interambulacral zones of the larger individual. This tint is very slightly darker on the interradius than on the ambulacral zones in the small individual. But in both, this tint becomes, in the middle of each interradial plate, a pink and clearly limited patch in the form of a lozenge, much wider than high, that straddles the horizontal suture. This lozenge touches nearly exactly by its external border the external border of the interradius. By its internal corner, it is very near the median suture, without however, touching the suture. The height of the colored lozenge is a little less than the height of the corresponding interradial plate, because between the successive losenges is a tubercle of the principal row. This tubercle, as well as the tubercles of the two other external and internal rows, has the same pink tint as the lozenge. The ambulacral zones have a similar appearance in each series, but in them the pink tint forms only a triangular area also straddlling the horizontal suture. The triangle that forms the patch is elongated horizontally. Its very pointed top nearly reaches the median radial suture, while its base stops at the poriferous zone. The successive triangles are likewise separated by the primary ambulacral tubercles of the external row that are pink. The other tubercles of the ambulacral areas still have this same pink tint. The borders of the pink regions are always marked by a darker line. Thanks to the alternations of pink and green tints, the test of $S$. roseo-viridis has a very elegant appearance.

In the small specimen B, the appearance is the same as in individual A, but the pinktinted spaces are not as wide as in the latter, especially in the ambulacral zones.

The very fine pores appear in the sutural corners of the ambulacral and interambulacral plates. These pores are very recognizable in the large specimen, but they are extremely small and scarcely apparent in individual B. It is fairly curious to see that $S$. roseo-viridis has from this point of view an arrangement inverse to that we see in the other species, where the pores are more apparent in the young than in the adults. We see also at the edge of the ambulacral and interambulacral plates some pores finer than the sutural pores, four or five on each interradial plate. We recognize them very well in the photograph reproduced in Pl. XII, fig 3, representing an enlarged portion of the test of the large individual. To the contrary, these pores are scarcely visible or complete lacking in specimen B.

The spines have the same characters as in S. bicolor. The large spines have a very slightly greenish color, with dark, fairly narrow purple rings. They are reddish at the base and their end is greenish. These spines remain always a little shorter than in S. bicolor of the same dimensions. The small spines do not have rings. They are red at the base and greenish at the end.

I have encountered in S. roseo-viridis tridactyle pedicellariae of two very different kinds, globiferous also of two kinds, ophiocephalous and trifoliate.

The tridactyle pedicellariae of the first kind are large. Their head reaches $0.9 \mathrm{~mm}$ in length. Their valves are strong and quite thick (Pl. XXVI, fig. $3 d$ ). The triangular basal part occupies more than a third of the total length. It is very large and wider than high. The blade is much narrower, but it remains fairly strong. It keeps the same width for its entire length, or even widens very slightly toward its end that is round and more or less curved. This end has on its free edge three of four very short teeth, conical with a round point. On the other hand, the blade has some teeth on its internal edge, most often three 
and sometimes four, large, short, conical and very large. They even form sometimes real little lobes.

The tridactyle pedicellariae of the second kind are small and quite small. They resemble the small tridactyles that we find ordinarily in the genus Salmacis. They recall notably those that Mortensen has represented in 1904 in Salmacis bicolor (pl. VI, fig. 39), but they are a little thinner. The length of their valves reaches $0.4 \mathrm{~mm}$ at the maximum. The large basal part is short. Its length is less than a third of the total. The blade forms a spoon, elongated and thin, whose edges are sometimes straight but that can have in the terminal third slight sinuosities forming some large teeth (fig. $3 a$ ).

The globiferous pedicellariae also have a large and a small form. In the pedicellariae of the large form, the valves have $0.6 \mathrm{~mm}$ in length. They are identical to those of $S$. bicolor represented in 1904 by Mortensen (pl. VI, fig. 26). The basal part, large and rectangular, is well over a third of the total length. The tube is very narrow. The terminal tooth is very developed, but there are no lateral teeth (fig. $3 \mathrm{~b}$ ). The valves of the small form measure only $0.2 \mathrm{~mm}$. The basal part reaches half of the total length. It is continuous insensibly with the blade from which it is less distinct than in the pedicellariae of $S$. bicolor represented by Mortensen. The unpaired lateral tooth is very developed and pointed $(3 c)$.

The ophiocephalous do not have special characters. The length of their head is 0.5 $\mathrm{mm}$. They are identical to those of S. bicolor represented by Mortensen in pl. VI, fig. 4 . The edges of the blade are more or less sinuous.

The trifoliate pedicellariae do not have anything special.

SIMILARITIES AND DIFFERENCES. - S. roseo-viridis is distinguished easily from all the known species of the genus Salmacis by the very remarkable color of the bare test that is green with large pink patches in the form of very regular lozenges on the interradial plates and triangular on the ambulacral plates. They are characterized in addition by the height of the ambulacral and interambulacral plates, by the relatively small number of primary tubercles that leave a good part or the surface of the plates bare, and finally by the presence of large tridactyle pedicellariae whose elongated and rather narrow blade has on its edge some very large teeth with a form that is absolutely unknown in the genus Salmacis.

The new species can be related especially to $S$. bicolor and rarispina with which it can be confused by a simple examination of specimens having spines that have absolutely the same characters as in these two species and forming a similar covering of the test, although less dense in $S$. roseo-viridis. One of the specimens of the INVESTIGATOR was moreover associated with Salmacis bicolor. By the less dense covering of the spines, by the small and less dense primary tubercles, the $S$. roseo-viridis recalls more $S$. rarispina than $S$. bicolor. But it is distinguished very clearly from these two species by the very special color of the spineless test, by the large tridactyle pedicellariae, etc.

Finally, the species of the INVESTIGATOR differs also from another Salmacis, very close to $S$. bicolor, that H. L. Clark has described recently under the name of S. rubricincta (1925, p. 86) after specimens also coming from the Indian Ocean (Salya de Malha, 40 fms), but the color is different. The test is a pale apple-green tending to white, especially on the ventral surface with white patches in the ambulacral and interambulacral zones. The spines have bright red rings, but the red spaces alternate with pure white spaces. 


\section{Mespilia globulus (Linné)}

See for the bibliography:

Mespilia globulus. A. Agassiz, 1872-74, p. 477; pl. VI, fig. 1; pl. VII $a$, fig. 13 and 14; pl. VIII $e$, fig. 14; pl. XXXVIII, fig. 22.

Mespilia globulus. Agassiz, 1881, p. 144.

Mespilia globulus. Mortensen, 1904, p. 96; pl, VIII, fig. 16, 17, 22, 35 and 47.

Mespilia globulus. H. L. Clark, 1908, p. 305.

Mespilia globulus. Rudnose Brown, 1910, p. 25.

Great West Torres. — 6 March 1886 — Tidal. — A single specimen.

The diameter of the test is $41 \mathrm{~mm}$ and the height is $29 \mathrm{~mm}$. The specimen is in very good condition and the spines are preserved. The ambulacral regions are a fairly dark pink in color and the interradial regions a very dark olive green.

Mespilia globulus is a well-known species. The pedicellariae described and figured by Mortensen are very characteristic. I have nothing to add to the descriptions of the authors relative to this species.

We know that Mespilia globulus has been encountered in various localities of the Indo-Pacific domain, at Japan, Sunda Islands, Mergui Islands on the coasts of Siam, etc.

\section{Prionechinus Agassizii Döderlein}

$$
\text { (Pl. XV, fig.1 and 2) }
$$

Prionechinus Agassizii. Wood-Mason and Alcock, 1891, p. 441.

Prionechinus Chuni. Döderlein, 1907, p. 192; pl. XIV, fig. 3; pl. XXXV, fig. 9, and pl. XLVI, fig. 3.

Prionechinus Chuni. H. L. Clark, 1912, p. 304.

Prionechinus Chuni. Lambert and Thiéry. 1911, p. 230.

$11^{\circ} 15^{\prime}$ N.; $91^{\circ} 16^{\prime}$ E. - $1840 \mathrm{fms}$, - One specimen.

$12^{\circ} 50^{\prime}$ N.; $90^{\circ} 52^{\prime}$ E. - 1644 fms. - One specimen.

The two specimens have spines on the ventral surface only.

The name Prionechinus Agasszii, given to this species by Wood-Mason and Alcock in 1891, being prior to that of $P$. Chuni that Döderlein applied to it six years later, must prevail.

The two specimens in the collection sent to me were both cited by Wood-Mason and Alcock. These authors have given a very brief and very insufficient summary of the description of the species to permit it to be recognized. A very complete description accompanied by photographs was published by Döderlein in 1907. 
Döderlein described $P$. Agassizii under the name of $P$. Chuni after a single specimen dredged by the VALDIVIA at 2,253 meters in the area of the Maldive Islands $\left(0^{\circ} 2^{\prime}\right.$ S.; $73^{\circ} 24^{\prime}$ W.) in a locality consequently very near where the INVESTIGATOR encountered the species. The ALBATROSS had found it before at the Sandwich Islands (Kahuku Point, Oahu) at a depth between 743 and $1278 \mathrm{fms}$. H. L. Clark kept the Name P. Chunni for it.

The specimen of the VALDIVIA measured $10 \mathrm{~mm}$ in diameter. The largest specimen of the INVESTIGATOR is a little larger. To the contrary, in the individuals collected by the ALBATROSS. Diameter of the test varied between 2 and $11 \mathrm{~mm}$.

The description given by Döderlein is very complete. I have verified it in my specimens. I have little to add to it. I shall content myself with giving some measurements relative to the two specimens of the Indian Museum that I shall designate respectively by the letters A and B.

\begin{tabular}{|c|c|c|}
\hline Specimens & $\begin{array}{c}\mathrm{A} \\
\mathrm{mm}\end{array}$ & $\begin{array}{c}\mathrm{B} \\
\mathrm{mm}\end{array}$ \\
\hline Diameter of the test & 12.5 & 9.2 \\
\hline Height of the test ... & 8.7 & 6.4 \\
\hline Diameter of the apical system & 6 & 4.8 \\
\hline Diameter of the periproct & 3 & 2 \\
\hline Diameter of the peristome & 6.3 & 5 \\
\hline 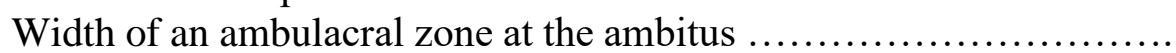 & 2.5 & 1.5 \\
\hline 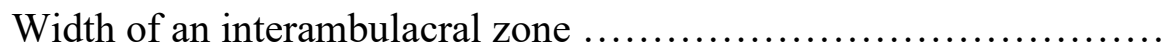 & 4 & 3 \\
\hline
\end{tabular}

I shall note only that the buccal plates of these specimens are smaller than those of Döderlein, as can be seen in comparing the photographs that I give here to those of Döderlein (1907, pl. XXXV, fig. 9). The German author says that the plate pairs are separated by an interval equal to the width of a buccal plate. Now I observe that this interval equals nearly the width of one pair of buccal plates. The plates that cover the periproct are perhaps a little smaller in my specimens, at least in the larger where they do not become much smaller toward the center of the periproct. The anus is slightly eccentric. It is surrounded by a circle of plates a little more elongated than the adjacent ones. In the small specimen, the anus is also a little eccentric, but the small plates that surround it are smaller than the adjacent ones.

The larger specimen is white, the smaller is yellowish. Döderlein has noted that the test and spies of his specimen were a cream color.

\section{Paratrema nov. gen.}

This genus differs from the genus Temnotrema by having five buccal plates only instead of five pairs and by globiferous pedicellariae with an extremely developed lateral tooth. The type of the genus is $P$. Döderleini described by Mortensen that he first placed in the genus Pleurechinius that has the principal characters except those that concern the buccal plates and the globiferous pedicellariae.

Mortensen has already called attention to these two characters that distinguish $P$. Döderlein from all the species of the genus Pleurechinus. He asked if there was not reason 
for his form to be a special genus, but he did not believe it was necessary to establish it. I think that the reservations kept by Mortensen are a little exaggerated and the characters that I just stated appear to me to be perfectly of the nature to justify a generic separation. I propose to create for Pleurechinus Döderlein a new genus that I shall call Paratrema.

All the species of Pleurechinus have five pairs of buccal plates and the valves of the pedicellariae have either two lateral teeth or are completely lacking. The unpaired lateral tooth of the genus Paratrema is extremely developed, as Mortensen noted. I observe in my specimens that it is even longer than the terminal tooth.

In the only species presently known of the genus Paratrema, P. Döderleini, the periproct is covered with small plates, numerous, unequal, and without a distinct anal plate.

\section{Paratrema Döderleini (Mortensen)}

Pleurechinus Döderleini. Mortensen, 1904, p. 77; pl. I, fig. 12 and 13; pl. II, fig. 1, 7 and 8; Pl. VI, fig. 35 and 43; pl. VII, fig. 10 and 48.

Temnotrema Döderleini H. L. Clark, 1912, p. 319.

Andaman Islands (without other indication). - Seven specimens.

Hong Kong (Hungerford leg.). — One specimen.

The specimen from Hong Kong is the larger. It measures 1 centimeter in test diameter by a height of $7 \mathrm{~mm}$. The other individual is smaller, the test diameter varies between 9 and $7 \mathrm{~mm}$.

The species has been very completely described by Mortensen and I have nothing to add to the description of this scholar.

\section{Temnotrema scillae (Mazetti)}

(Pl. XIV, fig. 12)

Temnechinus scillax. Mazetti, 1894, p. 213.

Pleurechinus scillac. Mortensen, 1904, p. 86; pl. I, fig. 9, 10, 17 and 18; pl. II, fig. 10 and 12.

Temnotrema scilla. H. L. Clark, 1912, p. 318.

Port Blair. - 15 fms. - Three specimens.

Andaman Islands. - 245-45 fms. - One specimen.

Andaman Islands. - Without other indication. - One specimen.

Two miles N. W. of Great W. Torres. — 5 March 1886. — 40 fms. - One specimen.

All the specimens are of small size. Their diameter is generally between 5 and 5.5 $\mathrm{mm}$. One of the specimens of Port Blair is only $4 \mathrm{~mm}$.

A very complete description of $T$. scilla has been given by Mortensen in 1904. My specimens fit it perfectly. The sculpturing of the test is the same. In all the specimens, the 
periproct is, in principle, covered by a single plate, shiny and glassy, with fine concentric and radial streaks. The arrangement is identical to that which Mortensen described in a specimen from New Britain and that he represented in pl. XI, fig. 10 from his memoir. This single plate is not always circular. In the specimen from Torres, it is very slightly oval. In a specimen from the Andaman Islands, it is a little polygonal. It sometimes adds to this, three large plates and a small number of very reduced plates. All the individuals lack their spines.

T. scillae was first placed by Mazetti, who described it, in the genus Temnechinus. It was Mortensen who assigned its correct place in the genus Pleurechinius. H. L. Clark, in 1912, noted that it was difficult to know exactly what should be the type of the genus Pleurechinus and, as Agassiz had created in addition a genus Temnotrema for an urchin from Japan that is identical to Pleurechinus variegatusI described by Mortensen in 1904, it was preferable to substitute the latter generic term for the term Pleurechinus. I willingly accept this change in denomination. The genus Temnotrema contains thus at the present eight species according to H. L. Clark. It is under this name that I shall describe the second species in the collection of the Museum of Calcutta.

The change in denomination proposed by H. L. Clark results moreover in changing the limits of the genus Pleurechinus. It is necessary to recognize that the genus Temnopleura is not better characterized than the genus Plleurechinus. I have already proposed above to separate generically $T$. Döderleini from the other species of the genus Temnopleura in making it the type of the genus Paratrema. It is possible that we shall be led to divide the genus Temnotorema into two others. A revision of the species Temnotrema (or Pleurechinus) is necessary. Unfortunately, I do not have sufficient documentation to make this revision.

Lambert and Thiéry substituted, in 1911, the term Dicoptella for the term Pleurechinus. Although the first genus had been created by Lambert in 1907, it is the genus proposed by H. L. Clark in 1912 that should prevail. In fact, as the American author explains, the genus Tremnotrema was established by Agassiz, and its type, T. sculptum from Japan, is identical to the Pleuechinus variegatus described in 1904 by Mortensen (see H. L. Clark, 1912, p. 317).

\section{Temnotrema siamense (Mortensen)}

$$
\text { (Pl. XIV, fig. } 11 \text { and 14) }
$$

Pleurechinus siamensis. Mortensen, 1904, p. 79; pl. I, fig. 2, 7, 11 and 20; pl. II, fig. 2, 9, 14, 15 and 22; pl. VI, fig. 6 and 36; pl. VII, fig. 14, 44 and 53.

Temnotrema siamense. H. L. Clark, 1912, p. 318.

$6^{\circ} 01^{\prime}$ N.; $81^{\circ} 16^{\prime}$ E. $-34 \mathrm{fms}$. - Four specimens.

All four specimens are of small size. In the largest, the diameter does not exceed 5.5 $\mathrm{mm}$. The height is not very great. In the largest specimen it is $4 \mathrm{~mm}$. The ratio between the height and the diameter is thus very slightly less than that Mortensen indicated. In one 
of the specimens he studied, the diameter of the test was in fact $79.5 \mathrm{~mm}$ and the height $5 \mathrm{~mm}$. The ratio was thus $115 \mathrm{k}$, while in mine, the ratio is very slightly less at 1.5 .

All the specimens lack spines.

These specimens conform well to the type of Mortensen in terms of the structure of the test. One of the plates of the periproct is always much larger than the others with some variations.

Three of the specimens are pale greenish gray with some darker bands in the middle of the interambulacral zones. The fourth individual is a fairly uniform pink color. In the individuals studied by Mortensen, the color of the test was greenish was some white irregular patches and the median region of the interradius of the dorsal surface was darker.

I have not encountered pedicellariae, but Mortensen has been able to observe ophiocephalous, globiferous and trifoliate pedicellariae. The valves of the globiferous observed by this scholar lacked the lateral tooth. It has only a small round button on the sides.

The type of $T$. siamense comes from the coasts of Siam. It has been found at shallow depths between 3 and 38 fms.

\section{Trigonocidaris versicolor nov. sp.}

$$
\text { (Pl. XIV, fig. 3, 4, } 6 \text { to } 10 \text { and 13; pl. XXVII, fig. 1) }
$$

Station 237. - $13^{\circ} 17^{\prime}$ N.; $93^{\circ} 7^{\prime}$ E. -90 fms. - Numerous specimens.

Andaman Seas. - $100 \mathrm{fms}$. - Two specimens.

The specimens are all of small size. The diameter of the test is usually between 7 and $9 \mathrm{~mm}$. One individual coming from station 237 is larger than the others. Its diameter is $10.5 \mathrm{~mm}$. The two specimens from the Andaman seas measure 5 and $6 \mathrm{~mm}$.

I believe I am able to refer these specimens to the genus Trigonocidaris because of the characters of the buccal membrane that has over its entire surface very apparent imbricated plates, as well as the form of the pedicellariae, especially the globiferous. The periproct is covered with very few plates, one of which is much larger than the others. But the appearance of these plates is similar to those that Döderlein has described in the genus Lamprechinius.

It is rare that the dorsal surface of the test is regularly convex. Most often, it is flat in the central region. The height is less than half the diameter of the test. The height does not exceed $4 \mathrm{~mm}$ in the specimens whose test is $9 \mathrm{~mm}$ in diameter.

The apical system is small. The genital plates are unequal, pentagonal, nearly as wide as high, largely contiguous on their lateral borders and with a round top. The fairly large gonopore is near the top. The madrepore is a little larger than the others. The pores cover only a fairly narrow portion that is generally a little protruding. The ocellars are large, wider than high, triangular with a convex distal border and a rather small opening. All are far away from the periproct. This is covered with large triangular plates, most often four in number, one much larger than the others and of variable dimensions. The plate that is opposite to the large plate is notably smaller. The two others have intermediary dimensions. Sometimes these four large plates alone cover the entire periproct. Sometimes extremely small plates are intercalated between them, to the number of three or four, very 
rarely more (Pl. XIV, fig. 4 and 10). The large plate is located opposite interradius 3 or in a nearby position. Only once have I found it opposite interradius 2 .

The genital plates are always very shiny, like glass. They have in addition radiating streaks formed by extremely dense granules, very numerous and very fine. The central region of the large plate is more or less protruding. The others are also a little swollen. These plates are always green, sometimes very pale and becoming greenish, sometimes darker. The genital plates have also in places this same green color. In principle, each of these plates has a large patch toward its lateral borders. Each of these patches is continuous with the corresponding patch of the adjacent plate. There is finally a third patch toward the top. The rest of the plate is white. The green regions have also fine striations, but less marked than on the periproct plates. The ocellars are white.

The peristome is large. Its diameter is $4 \mathrm{~mm}$ in a specimen whose test diameter is 9 $\mathrm{mm}$. It is completely covered with dense, imbricated plates, wide and very narrow toward the periphery of the peristome, becoming higher and narrower toward the mouth, becoming finally nearly as wide as high. The ten primary plates, contiguous in pairs, are large and polygonal.

The ambulacral areas, like the interambulacral areas, have each two rows of primary tubercles. The ambulacral tubercles are scarcely smaller than the interambulacrals. The ambulacral areas are very wide and the poriferous zones are also wide. The pores are rather large. The successive pairs follow a nearly straight line.

The sculpturing of the test is less marked than in T. albida.. It consists especially of transversally widened pits, separated by fairly wide oblique lines, more marked in the interradial regions than in the ambulacral zones. This sculpturing is less apparent in the large specimen whose test is $10.5 \mathrm{~mm}$ in diameter. The auricles are always widely open from above. They are formed of two widely separated stems, sometimes a little convergent toward each other, sometimes rising parallel.

The primary spines measure 2 to $2.5 \mathrm{~mm}$ in length. Their surface is smooth. The spines are white or slightly greenish, a little paler than the test itself whose general tint is a pale greenish gray. But the bare test always shows in the middle of each ambulacral and interambulacral area a more or less wide band of a much darker tint than the rest. Sometimes these bands are green, sometimes they are a greenish-brown or even completely brown. These bands disappear at the ambitus. The ventral surface is grayish white of slightly greenish.

I have found on my specimens four kinds of pedicellariae: tridactyles, globiferous, ophiocephalous and trifoliate. Only the ophiocephalous are abundant. The others appear much rarer. The head of the ophiocephalous measures approximately $0.2 \mathrm{~mm}$ in length. The valves are elongated and narrow, strongly narrowed in the middle. The blade has an ordinarily sinuous edge. The sinuosities are unequal and irregular sometimes they are not marked (Pl. XXVII, fig. $1 c$ ).

The valves of the globiferous measure 0.12 to $0.14 \mathrm{~mm}$ (fig. $1 \mathrm{a}$ ). They absolutely resemble those of T. albida that Mortensen figured in 1903 (pl. VII, fig.31). The trifoliate resemble likewise those of $T$. albida figured by Mortensen (pl. VII, fig. 23). The tridactyles (fig. $1 b$ ) appear vary rarely and nearly all that I have observed in my preparations were broken by the middle. The union of the basal part with the blade is made by a region that is not strongly narrowed. The length of the valves varies between 0.15 and $0.2 \mathrm{~mm}$. The basal part is triangular and short, two times longer than wide. It 
ends in a strongly rounded edge. The perforations are numerous. These pedicellariae recall those of Lamprechinus nitidus figured by Döderlein in 1907 (pl. XLVI, fig. 6 b).

SIMILARITIES AND DifFERENCES. - As I said above, the four large plates that habitually cover the periproct greatly recall the arrangement indicated by Döderlein in the genus Lamprechinus. We can be convinced by comparing my photographs to those that Döderlein published in 1907 (pl. XXIII). But there is no question of referring the urchin discovered by the INVESTIGATOR to the genus Lamprechinius because of the very developed covering of plates of the buccal membrane. The application to the genus Trigonocidaris appears correct to me.

We know that the genus presently contains one species, $T$. albida), the $T$. albidoïdes created by Agassiz and Clark in 1907 for a form from the Hawaiian Islands being united with T. albida. The SIBOGA has encountered T. albida in the Sulu Archipelago. We see thus that this species exists in the three oceans, Atlantic, Indian and Pacific. The species discovered by the INVESTIGATOR is clearly separated from T. albida by the swollen plates of the periproct and having a green or greenish color, wider poriferous zones with larger pores, by the shallower sculpturing of the test and especially by the coloration.

I give here the photograph of the dorsal surface of a $T$. albida from the Atlantic to permit a comparison of its characters to those of the new species (PI. XIV, fig. 5).

\section{Printechinus nov. gen.}

Temnopleuridæ whose test is elevated, strongly convex on the dorsal surface, and with a flat ventral surface. The ambulacral plates are fairly wide and high. The poriferous zones are fairly wide. The pores are arranged in arcs of three scarcely distinct pairs. They form nearly straight lines. The interambulacral plates are very high and very large. The median line of each zone, both in the radius and in the interradius, has small sutural pits, round and punctiform. In addition, there are very large vertical depressions with parallel and deep borders, arranged parallel to each other and whose length nearly equals half the height of the plate. These depressions pass from one plate to the other in crossing the horizontal suture. In the interradius, they number three at least on each plate at the ambitus. Then their number decreases toward the periproct and the peristome. Similar depressions, but smaller and more often only one pair per plate, exist in the ambulacral zones. The rest of the surface of the coronal plates is smooth. The primary tubercles are very small, not much larger than the secondaries. They are distinctly crenulated, nonperforated and not numerous. The secondary tubercles are fine and also few, except on the ventral surface of the test. The middle of the ambulacral and interambulcral zones remain bare on the dorsal surface of the test. The peristome has distinct and fairly deep notches. The buccal membrane lacks plates. All the ocellar plates are separated from the periproct. The plates that cover them are not numerous. One of them is notably larger than the others. The genital plates are divided by a transverse depression into two equal halves. The pedicellariae have four forms: tridactyle, globiferous, ophiocephalous and trifoliate. The valves of the globiferous lack lateral teeth. 
The genus Printechinus belongs to the family Temnopleuridæ and the group of Trigonocidarinæ. It has some affinities with the genus Orechinus Döderlein by the sculpturing of the test, the small size of the primary tubercles, the rows of the successive pore pairs forming a nearly straight line, but it clearly differs from it by its crenulated tubercles, little developed and not numerous, ambulacral and interambulacral zones bare in the middle, and by the presence on the median line of each zone of sutural pores independent of the characteristic large vertical depressions that cross the horizonal sutures of the plates. The plates of the periproct are more numerous and the globiferous lack a lateral tooth.

The genus Printechinus is separated more from the neighboring genera Opechinus, Lamprechinus, Prionechinus, Genocidaris, etc.

Printechinus impressus nov. sp.

(Pl. XV, fig. 3 to 11 , and Pl. XXVII, fig. 20

Station $238 .-13^{\circ} 16^{\prime}$ N.; $93^{\circ} 08^{\prime}$ E. $-60-75$ fms. — Seven specimens.

Three specimens have nearly the same dimensions. I have dried one of them in order to remove the spines and study the structure of the test. The four other individuals are smaller. I shall distinguish them respectively by the letters A to D.

Here are the principal dimensions that I have taken on these four individuals.

Specimens

Diameter of the test

Height of the test

Diameter of the peristome

Diameter of the apical system

Diameter of the periproct

Width of the ambulacral zone at the ambitus ........

Width of the interambulacral zone ...................

Length of the spines

$\begin{array}{cccc}\begin{array}{c}\mathrm{A} \\ \mathrm{mm}\end{array} & \begin{array}{c}\mathrm{B} \\ \mathrm{mm}\end{array} & \begin{array}{c}\mathrm{C} \\ \mathrm{mm}\end{array} & \begin{array}{c}\mathrm{D} \\ \mathrm{mm}\end{array} \\ 24.4 & 24.2 & 23 & 16 \\ 17 & 18.5 & 17.5 & 10 \\ 9.2 & 8 & 7 & 6 \\ 6 & 5 & 5 & 3.7 \\ 2.7 & 3 & 3 & 2 \\ 5 & 5 & 4.2 & 3.5 \\ 11 & 10 & 9 & 6 \\ 3 & 3 & 3 & 2.5\end{array}$

The test is globular, very elevated in the large individuals, more depressed in the others, with a flat ventral surface. But the dorsal surface is very strongly convex, the contour of the test is round or sometimes a little sub-pentagonal.

The genital plates are rather large, fairly widely contiguous. They form a continuous ring. They have a hexagonal form, with a round or even slightly truncated distal corner. They are wider than high. The madreporite is a little larger than the others. Its surface is in large part occupied by fine, but very dense pores. They leave free a proximal border with three secondary tubercles. This plate has no trace of a depression on its surface, but the four other genital plates have a very clear transverse depression that separates each of them into two equal halves. This depression is not very deep. It starts from the middle of the plate where it is very narrow. Then it widens as it approaches the sides of the plate. It encroaches a little on the adjacent ocellar. This depression thus divides each plate into 
two parts. The proximal one has two or three secondary tubercles with, sometimes, one or two miliary tubercles. A nearly smooth distal one has the gonopore that is small and near the external corner of the plate.

The ocellars are small, pentagonal, a little wider than long. Their small proximal region is slightly depressed. This depression follows that of each genital plate. The distal part of the ocellar plate, much larger, is to the contrary a little projecting. It has some small tubercles. All the ocellar plates have the same form and none is contiguous with the periproct.

The latter is covered with very irregular plates, among which some are fairly large. One of them remains peripheral and is contiguous with genital 3 and notably larger than the others. The central region of this large plate is fairly strongly swollen. All the periproct plates are shiny and glassy. They have an elegant ornamentation, consisting of very fine striations formed by small granules arranged radially. The anus is slightly eccentric. This structure of the periproct recalls that we know in the genera Lamprechinus Orechinus, etc.

The ambulacral plates are large and high. At the ambitus, each plate is 0.6 in height by $3 \mathrm{~mm}$ in width. I count twenty-one major plates in each zone. Each of them has a small primary tubercle located toward its middle, a little nearer the ventral suture than the dorsal suture, and likewise nearer the external border of the ambulacrum than the median line. These tubercles scarcely measure more than $0.5 \mathrm{~mm}$ in diameter at the ambitus. They are surrounded by a very narrow scrobicular circle. It has fine but very clear crenulations. These crenulations are more apparent at the ambitus and on the ventral surface than on the dorsal surface of the test. Above each primary tubercle and toward the upper suture of the plate is a secondary tubercle. All thee tubercles form together a very regular vertical line. Each plate is thus divided into two lateral parts that are a little unequal. The internal part that extends to the median suture is a little wider. It is nearly rectangular. It is nearly completely bare and smooth above the ambitus. At the ambitus and below, it has in its middle a small secondary tubercle with some miliary tubercles. The secondary tubercules form first a very regular row, but in the area of the peristome, the tubercles become more numerous and irregularly arranged. The external region of each plate, narrower, is occupied by the poriferous zone that is relatively wide. The pores are arranged in arcs of three very regularly arranged pairs. They are not actually arcs, but straight lines that are scarcely oblique so that the poriferous zone on each side forms a straight band with scarcely seen sinuosities. The pores do not reach the external border of each zone. They leave free a narrow band that remains bare. Inside, they are contiguous with the primary and secondary tubercles forming the principal vertical row that I reported above. The poriferous zones completely lack tubercles.

The very small round and punctiform pits are in each corner of the plates in the median sutural line. These small pits are more of less apparent. They are generally more marked on the dorsal surface than on the ventral surface of the test. Another identical pit is often seen outside the median pit to which it is more or less close and with which it can be confluent.

Immediately inside the principal row of tubercles, and straddling each horizontal suture, we see a fairly deep depression, elongated vertically and which, at the ambitus, measures approximately $1 \mathrm{~mm}$ in height. This depression corresponds to the interval separating the primary tubercle from the secondary tubercle that is found on each 
ambulacral plate, as we just saw. These depressions are developed on two of three plates that are found above the ambitus. Then they shorten toward the apical system so that the first depressions of each series that follow this system are simply round. As, on the other hand, the ambulacral zones are very narrow in this region, thee depressions become mixed with the small sutural pits of the median line. We can see, toward the third and fourth ambulacral plates, the pit is separated progressively from the depression with which it was mixed in the first plates of the series. Toward the ambitus or a little above, we see a second depression appear inside the first, between it and the median line. But this depression always remains less important. The form is simply elliptical. The first even remains perfectly circular. They disappear below the ambitus while the others can be followed up to the area of the peristome. But they also shorten more and more and finish by becoming circular and then disappear.

The interradial plates are large and extremely high above the ambitus. I count thirteen in each series. These plates reach their maximum height from the third to the sixth inclusive. This maximum is approximately $3 \mathrm{~mm}$. Their width increases from the third, that measures more than $4 \mathrm{~mm}$ to the sixth that measures $5 \mathrm{~mm}$ in width. Beyond, the dimensions, especially the height, decrease progressively below the ambitus to the peristome. Each interradial plate has a primary tubercle scarcely larger than the tubercle of the ambulacral plate located at the same level. The tubercle is not in the exact center of the plate. It is nearer its ventral suture and the external border. Each plate has, in addition, some very sparse and not numerous secondary tubercles, to the number of four to six per plate. These tubercles leave free the internal region of the plate so that the middle of each interambulacral zone remains bare above the ambitus. Below the ambitus, the tubercles become notably more numerous. Some secondary tubercles, ordinarily two and sometimes even three per plate, take the size of the primary tubercle. The secondary tubercles themselves become much more numerous. These tubercles form ordinarily a fairly regular row on each side of the principal row, with still other tubercles in addition.

It is on the interambulacral zones that the vertical depressions of the test, so characteristic of the genus, reach their complete development. The depressions straddling each horizontal suture, are in general three and sometimes even four in number above the ambitus. They form on each side of the median line an extremely apparent group in which the more internal depression is shorter. The others can reach a height of $2 \mathrm{~mm}$. The depressions are much more important and marked than in the ambulacral zones. The always have some depth but this is not always uniform for their entire length. It is accentuated sometimes toward their end. It is at the ambitus that these depressions reach their maximum development. We sometimes find four of them, as I have said above. It can even add a fifth near the border of the interradius that remains simply elliptical. Toward the apical system, the number of depressions of each group falls to three, then to two that become irregular and short, more or less oval. Finally, they are reduced to one that is nearly circular. On the ventral surface, the depressions also shorten toward the peristome. Their number decreases in each group. They disappear a short distance from the buccal membrane.

The successive groups of these depressions are extremely apparent, not only because of their depth, but because of slightly greenish color, a little different from that of the rest of the test that is brownish. 
Of course, we find in the entire length of the median interradial line and to the level of each sutural corner the same small round pit as in the ambulacral areas. Even the pits there are more marked there than in the latter.

The peristome is of average size with well-marked notches, wider than deep. The membrane is thin and has no distinct plate inside and outside the circle of ten primary plates. Each of these has a miliary tubercle. The buccal membrane contains in its thickness C-shaped spicules that are found also in the tube feet.

The auricles are of average dimensions. The apophyses are thin and narrow. The opening is very large, in the form of a nearly equilateral triangle with round corners ( $\mathrm{Pl}$. $\mathrm{XV}$, fig. 3).

The spines are not numerous, fairly fine, with a pointed but round end. As the middle of the ambulacral and adambulacral areas is bare and, in addition, the spines are short, the specimens in alcohol have a bare appearance, it appears at first that the spines are absent. But we quickly see that most of them are preserved. They always remain short and only form a true important covering on the ventral surface of the test. The spines of the dorsal surface are sometimes green, sometimes not colored, but always lacking rings. On the ventral surface, the spines are green at the base. They have some red and white rings. The secondary spines are simply green at the base, then not colored at the end. But they also have some green and white rings. The test has a color generally brownish or more or less dark brownish-gray. The periproct is greenish. They regions that have the vertical depressions, principally in the interambulacral areas, are greenish. The ventral surface is paler.

The habitual four kinds of pedicellariae, tridactyles, globiferous, ophiocephalous and trifoliate are represented in Printechinus impressus (Pl. XXVII, fig. 2).

The head of the tridactyle pedicellariae measures approximately $0.3 \mathrm{~mm}$ in length. The valves are large and short. The basal region is more than a third of the total length. The blade forms an oval spoon with a round free end. It has two or three short denticulations, very large toward the end. The lower arcs are very developed (fig. $2 c$ ).

The head of the ophiocephalous measures $0.4 \mathrm{~mm}$ in length. The basal region of the valves is short and strong, much shorter than blade. Its borders are sometimes simply lobed, sometimes with three or four large, very wide and low teeth (fig. $2 d$ ). Some pedicellariae are much smaller than the others.

The head of the globiferous scarcely measure $0.3 \mathrm{~mm}$ in length. The valves are very delicate. The basal part is fairly developed, rectangular, with more or less projecting but rounded upper corners. The tube is one and a half times longer than this part. It ends in a pointed hook above which we do not see a lateral tooth. The walls of these pedicellariae contain numerous $\mathrm{C}$-shaped spicules.

The valves of the trifoliate pedicellariae are 0.1 to $0.13 \mathrm{~mm}$. The basal part and the lower arcs are very short. Together they are shorter than the blade that is slightly wider and whose form is nearly regularly circular (fig. $2 b$ ).

\section{Stomopneustidæ}




\title{
Stomopneustes variolaris Lamarck
}

\author{
(Pl. XXVII, fig. 3)
}

See for the bibliography:

Stomopneustes variolaris. Meijere, 1904, p. 87.

Stomopneustes variolaris. H. L. Clark, 1908, p. 303.

Stomopneustes variolaris. Jackson, 1912, p. 114, fig. 107-110.

Stomopneustes variolaris. H. L. Clark, 1912, p. 229; pl. XC, fig. 11 and 12.

Stomopneustes variolaris. H. L. Clark, 1923, p. 378.

? Stomopneustes atropurpurea. Woods, 1883, p. 93.

Anderson reported in 1894, p. 6, several specimens of St. variolaris collected by the INVESTIGATOR south of the Laccadive Islands on rocks. These specimens have not been sent to me and I find in the collection that was given to me only one individual with a label partly effaced and on which I can read only Ceylon, as well as four dried specimens from Station 296.

St. variolaris is well known now, thanks especially to the very precise information that was furnished by Mortensen in 1903. This author has described the pedicellariae that are fairly rare, notably the globiferous whose form is remarkable by lacking the terminal tooth and the particular characters of the spicules of the tube feet. These characters had already been indicated in part by Stewart. The spicules have not been figured. I reproduce here (Pl. XXVII, fig. 3) some photographs of the three principal forms of the bodies that we encounter in the tube feet, i.e, fenestrated plates, thin and with large openings, triradiate spicules and finally, thick rods, a little spiny that have often the form of a cookie and that have a very curious external resemblance to the sclerites of some holothurians, such as Holothuria tubulosa of our coasts.

It is very difficult at the moment to decide if the genus Stomopneustes has one or two species and if the St. atropurpurea from Queensland, described by Woods, is distinct from St. variolaris.

All authors accept the family Stomopneustidæ established by Mortensen in 1904, whose type is the genus Stomopneustes.

St. variolaris is a littoral species reported at Madagascar, Mauritius, in the Persian Gulf and the Sea of Oman, at Ceylan, in the Sunda Archipelago, at New Guinea, etc. It would be in Australia if it is proven that the form atropurpurea should be united specifically with it. As H. L. Clark noted, St. variolaris has never been reported in the North Pacific nor in the seas of Japan.

\section{Echinidæ}

Lytechinus Thieryi nov. sp. 
I owe to the kindness of M. Thiéry the communication of a specimen collected at Ceylan and that certainly represents a new species of the genus Lytechinus. This species does not exist in the collections of the Indian Museum. But because of the provenance of the specimen, it appears useful to me to make it known here and to compare it with the other forms of the Indian Ocean.

The single individual is in good condition, but it is dry. At least half of the test lacked spines when the specimen was sent to me.

Here are the principal dimensions I have taken of this individual.

\begin{tabular}{|c|c|}
\hline \multirow{2}{*}{\multicolumn{2}{|c|}{ Diameter of the test }} \\
\hline & \\
\hline 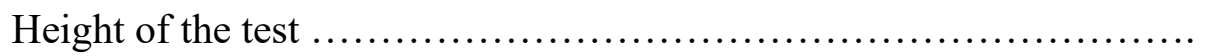 & 14 \\
\hline Diameter of the apical system & 4.5 \\
\hline Diameter of the periproct $\ldots \ldots \ldots \ldots \ldots \ldots$. & 1 \\
\hline Diameter of the peristome $\ldots \ldots \ldots \ldots \ldots \ldots \ldots$ & $2.5 \times 2$ \\
\hline 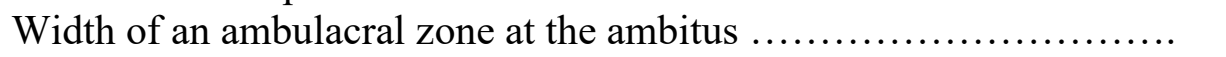 & 6 \\
\hline Width of an interambulacral zone at the ambitus ...................... & 8 \\
\hline Length of the primary spines $\ldots \ldots \ldots \ldots \ldots \ldots \ldots . . . .$. & 6 \\
\hline
\end{tabular}

The apical system has the usual structure of the genus Lytechinus. Genital plates 2, 3 and 4 are stronger and longer than plates 5 and 1 . Ocellalr $V$ touches the periproct by a small, truncated border and ocellar I by a wide border. The periproct is slightly oval and elongated after I-3. The genital plates have a fairly narrow distal corner near the top that has the gonopore, which is small and round, located a little toward four-fifths of the length of the plate. The madreporite is large and protruding. The madreporite pores occupy the entire surface inside the gonopore. Its form is pentagonal. It is a littler longer than wide. Genital plates 3 and 4, unequal, are also pentagonal, nearly as high and narrower than the madreporite, sensibly higher than wide. In these three plates, the two lateral borders of each side are very unequal. Genital 5 is small and pentagonal, but the two laterals are nearly equal, and the height equals the width. Finally, plate 1 is a little larger than the preceding and a little smaller than plates 3 and 4 . But its form is the same as that of the latter.

Ocellars II, III and IV are unequal, a little wider than long, pentagonal with a proximal top and two lateral borders on each side. The sides that limit the proximal corner are larger than the others. Plate V is hexagonal, its proximal top being truncated and forming a very short border contiguous with the periproct. Plate I is hexagonal, wider than high with, on each side, two small equal lateral borders and a large proximal side that touches the periproct. The latter, slightly oval, is covered in its region contiguous with genitals 2,3 and 4 , by three large plates. That which touches genital 3 is larger than the other two. The rest of its surface is filled with much smaller plates that are not very numerous. Each genital plate has a small primary tubercle. The ocellars have some secondary tubercles.

The peristome is very large with shallow notches. It is covered with numerous imbricated, very dense plates, forming a solid covering. It extends uniformly outside and inside the ten primary buccal plates. These, nearer the internal border than the external 
border of the buccal membrane, are small. They are scarcely distinguished from the adjacent imbricated plates. These plates have only a small number of miliary tubercles.

The primary ambulacral tubercles succeed each other very regularly in each ambulacral zone. They are close together. I count twenty-four to twenty-five on each side. Their dimensions increase very regularly to the area of the ambitus, always remaining smaller than those of the interambulacral tubercles at the same level. All the region located outside the row of primary tubercles is occupied by the pores. Inside, we see only a single row of small secondary tubercles, only one per plate above the ambitus, sometimes two below. The rest of the plates, on both sides of the median suture, remain bare. The pores, completely equal, are very regularly arranged in arcs of three pairs.

The interambulacral plates are large and approximately two times wider than high. Each has, toward its middle, a large primary tubercle. These tubercles form a very regular vertical row on each side. The dimensions increase very rapidly from the first of these tubercles to the fourth or fifth, then more slowly toward the ambitus. Toward the sixth or seventh plate, we see appear on both sides of this principal row, another row of tubercles that are at first much smaller. But the dimensions increase very rapidly so that, at the ambitus, these tubercles are not much smaller than the principal tubercles, especially in the row adjacent to the median suture. There is generally only one of these lateral tubercles per plate, but sometimes there are two. The rest of the plate is filled with very small tubercles, not numerous or dense, of variable size.

The bare test has a grayish tint, slightly violet.

The spines form a fairly dense covering of the test. The primary spines are white, slightly greenish in their first half and reddish in the second half, without rings. They are fairly wide and truncated at the end.

The wall of the tube feet contains small C-shaped spicules that are not numerous.

I have found in this individual four kinds of pedicellariae: tridactyles, globiferous, ophiocephalous and trifoliate (PL. XXVII, fig. 6). The elongated valves of the globiferous pedicellariae measure 0.2 to $0.25 \mathrm{~mm}$ in length. The wide basal part continues progressively with the blade that forms a very narrow and elongated tube, one and a half times longer than the basal region. The blade slightly widens toward its end. It ends ini a strong hook. There are no lateral teeth (fig. $6 \mathrm{e}$ ). This form greatly recalls that which Mortensen represented in L. variegatus. The pedicellariae contain very numerous small calcareous spicules in their walls. Some are arched and end in pointed or swollen ends. Others are not arched and have swollen ends. Others are simply globular. All form a series similar to that which Mortensen has represented in L. variegatus in 1903 (pl. XX, fig 15, and pl. XXI, fig. 31, 38 and 40).

The tridactyl pedicellariae have a fairly thick and short head, measuring $0.15 \mathrm{~mm}$ in length (fig. $6 \mathrm{~b}$ ). The valves are fairly stocky and rather short. The basal part is only a little shorter than the blade. This forms a fairly wide spoon, oval, with fairly large and dense perforations. It has on its edge, in the terminal half, two of three very wide and very low teeth. This form of tridactyles recalls that of the tridactyles that Mortensen has represented in L. verruculatus in 1903 (pl. XXI, fig. 2). Some other tridactyles are still smaller than the preceding $(c)$.

The head of the ophiocephalous pedicellariae measures $0.3 \mathrm{~mm}$ in length. The form of the valves greatly recalls that which Agassiz represented in L. variegatus in his Révision (pl. XXV, fig. 19). The length of the basal part is equal to that of the blade as in 
the latter species. But here, the basal region has a more triangular form and is separated from the following region by a very marked constriction. The blade has on its edge large teeth that are low and wide (fig. $6 d$ ).

The valves of the trifoliate pedicellariae measure $0.06 \mathrm{~mm}$ in height. They are nearly as wide as long. The basal part is very short. The blade, a little narrowed at the base, widens to end in a slightly convex edge. The perforations are numerous, dense and very regularly arranged (fig. $6 a$ ).

SIMILARITIES AND DIFFERENCES. - The two species that the new Lytechinus is closest are L. rufus (Bell) and variegatus (Lamarck). The first species that comes from the Indian Ocean was described by Bell, as Mortensen showed, under the name Salmacis rufa and by Meijere under the name of Gymnechinus pumilus. It is distinguished by spines with rings and by its apical system in which ocellus I only is contiguous with the periproct. The tridactyle and ophiocephalous pedicellariae represented by Mortensen and the globiferous represented by Meijere are very different from those of $L$. Thiery.

The new species is much closer to L. variegatus of the Atlantic that has, like it, ocellars I and V contiguous with the periproct. The globiferous pedicellariae appear identical in the two species and the ophiocephalous pedicellariae, although very close, are not absolutely identical. In contrast, the tridactyles are completely different. The two species cannot be confused.

I reported above the resemblance of the tridactyle pedicellariae to those of $L$. verruculatus, but the characters of the test, notably the tuberculation, completely separates the two species from each other.

\section{Toxopneuses pileolus (Lamarck)}

See for the bibliography especially:

Toxopneustes pileolus. Mortensen, 1904, p. 120.

Toxopneustes pileolus. H. L. Clark, 1908, p. 305.

Toxopneustes pileolus. Rudnose Browon, 1910 a, p. 41.

Toxopneustes pileolus. H. L. Clark, 1912, p. 283; 1915, p. 98; 1923, p, 386, and 1925, p. 123.

Ceylan. - $26 \mathrm{fms}$. - Four specimens whose diameter is between 67 and $23 \mathrm{~mm}$.

I have no remarks to make relative to this well-known species widespread in the IndoPacific domain.

\section{Tripneustes gratilla (Linné)}

See for the bibliography especially:

Tripneustes gratilla. Meijere, 1904, p. 95

Tripneustes gratilla. Döderlein, 1914 p, 489,

Tripneustes gratilla. H. L. Clark, 1914, p. 286; 1915, p. 98; and 1923, p. 387. 
Gulf of Ceylan (without other indication). - Two specimens.

Table Island (south Andaman). - 15-35 fms. - One specimen.

I have nothing to say on the subject of this well-known species distributed in the IndoPacific domain.

\section{Prymnechinus gen. nov.}

This genus of Echinidæ is near the genus Gymnechinus that it recalls by the periproct, large and asymmetrically in the direction IV-I, by the genital and ocellar plates nearly as wide as long and plate I not much shorter than the others, and finally by the triangular ocellars that are all separated from the periproct.

The ambulacral and interambulacral plates are large and not numerous. They form in each area a very regular double row. The pores are regularly arranged in arc of three pairs. In the single species known, the periproct is nearly completely covered with very large plates, round or slightly polygonal, to which are added some very small plates. The anus is between them. The buccal membrane is bare. The two primary plates of each pair are very unequal. One of them, the larger, has only an ambulacral tube.

This genus is represented only by two small specimens that cannot be considered juveniles because both have gonopores.

I cannot avoid relating this new genus to the genus Gymnechinus because of the asymmetrical form of the periproct. But the differences are very important. First, the composition of the periproct is very particular. The apical system has a considerable development and covers a good part of the dorsal surface. This arrangement recalls that which exists in the genus Pygmaeocidaris, a specimen of which was found by the INVESTIGATOR, and in the fossil genus Tiarechinus. But the resemblance is due to the unusual dimensions of the apical plates. We cannot compare the genera Pygmaeocidaris and Prymnechinus that belong to different families. The affinities of the new genus are very near the genus Gymnechinus, but it is separated from it by very important differences. The inequality of the buccal plates of each pair is incontestably remarkable.

Prymnechinus proctalis nov. sp.

(Pl. XVII, fig. 11, 12 and 14)

Port Blair (Andaman Islands). - $112 \mathrm{fms}$. - Two specimens in which the diameter is between 7 and 9 $\mathrm{mm}$.

The spines are missing on the dorsal surface. They are in part preserved on the ventral surface, but most of the primary spines are broken. The test is strongly depressed, especially in the smaller specimen.

Here are the principal dimensions that I have taken on the two specimens that I shall call respectively $\mathrm{A}$ and $\mathrm{B}$. 


\begin{tabular}{|c|c|c|}
\hline Specimens & $\begin{array}{c}\mathrm{A} \\
\mathrm{mm}\end{array}$ & $\begin{array}{c}\mathrm{B} \\
\mathrm{mm}\end{array}$ \\
\hline Diameter of the test . & 9 & 7 \\
\hline Height of the test ............... & 5 & 6 \\
\hline Diameter of the apical system . & 4 & 4 \\
\hline Periproct...$\ldots \ldots \ldots \ldots \ldots \ldots \ldots$ & $2.4 \mathrm{X} 2$ & $2 \mathrm{X} 1.8$ \\
\hline Width of an ambulacral zone at the ambitus ............ & 2 & 1.5 \\
\hline Width of an interambulacral zone at the ambitus ....................... & 3.6 & 1.5 \\
\hline Diameter of the peristome & 3.7 & 3 \\
\hline
\end{tabular}

We see in the table above how considerable are the dimensions of the apical system. These dimensions are relatively a little greater in the small specimen. In the latter, the diameter of the system exceeds half the diameter of the test, while in the larger, it does not quite reach half. The peristome has a normal diameter and remains notably smaller than the apical system. The plates of the apical system are very large. The genial plates have, in the large specimen, a form slightly heptagonal, with the proximal border more or less concave. This is especially marked on plates 3 and 4 . The sides are formed of two very unequal borders and are connected by very obtuse corners. The large border is a little concave. The distal coroner is extremely obtuse and very rounded, not very distinct. Plates 3 and 4 are slightly higher than wide. Plates 2 and 5 are nearly as high as wide. Finally, plate 1 is a little shorter than wide. These plates are contiguous by the small lateral borders. The surface of the plates is smooth, without the least trace of tubercles. Plate 2 has the same form and contours as the other plates. The gonopore is very small, nearer the proximal border than the top. The madreporite pores are not numerous. They form a small group located toward the middle of the plate. The ocellars are large and triangular, a little wider than high and all equal. Plate I is a little nearer the periproct than the others but it remains however separate.

In the small specimen, the genital plates have the same characters, but they are a little shorter and more widened. Genital 1 has a proximal border deeply notched by the periproct. Ocellar I is nearer to the latter. The madreporite pores have the same arrangement as in the large individual. The gonopores are very small, but recognizable.

The periproct is pentagonal with a smaller side, contiguous with the genitals 3 and 4 . The distal top is notching genital 1 . The two contiguous sides respectively to genitals 2 and 3 and 4 and 5 are larger. They are divergent. The top corresponding to plate 1 is round in the large specimen and pointed in the small. There is thus a slightly narrower region corresponding to genitals 3 and 4, from which the periproct widens for two third of its length. From there, is narrows rapidly. The largest part of the periproct is filled by a very large elongated in the same direction $\mathrm{s}$ it. It fills especially the narrower part of the periproct. The large plate has an irregularly triangular form in the large individual. It is a little longer than wide. Outside it are small unequal and irregularly polygonal plates. The anus is located on the line IV-1. In the small individual, the large plate is nearly as long as wide. Most of this plate is filled, in both individuals, by a slightly circular depression.

The buccal membrane is very thin and completely bare. As I have said in characterizing the genus, the primary buccal plates are unequal. The larger only has a ambulacral tube. The largest plates correspond to regions I $b$, II $b$, III $a, \operatorname{IF~} b$ and V $a$. 
The ambulacral zones are fairly wide. The plates are very high, nearly as high as wide. I count eight of them in each row on the large specimen where they have nearly the same height as the corresponding interradials. Each of these plates has a primary tubercle in its middle. But the tubercles are always small on the dorsal surface of the test. They become important only toward the ambitus and on the ventral surface. The poriferous zones are fairly wide. The pores form arcs of three pairs, a little irregular. Successive arcs form a slightly sinuous line.

The interradial plates are very high, but wider than high. Each of them has a primary tubercle near the lower border of the plate. The size of the tubercles increases from the apical system to the ambitus. The secondary tubercles are not numerous, especially on the dorsal surface. They become more abundant on the ventral surface. The primary spines are unfortunately all broken and it is impossible to estimate their length. They are smooth and finely striated on the preserved part. The secondary spines are fine and pointed, but few.

The tube feet contain neither plates nor spicules in their walls.

I have encountered only ophiocephalous pedicellariae that do not have particular characters. They are fairy numerous on the test and are absent on the peristomial membrane. Their head has a length of $0.3 \mathrm{~mm}$.

The spines are white or slightly pinkish. The test is gray in the small specimen. To the contrary, it is very pale yellowish white in the larger.

\title{
Gymnechinus megaloplax H. L. Clark
}

\author{
(Pl. XVII, fig. 16)
}

Gymnechinus megaloplax. H. L. Clark, 1912, p. 287; pl. CII, fig. 2 and 3.

I do not believe I am mistaken in relating to G. megaloplax H. L. Clark a small specimen whose label simply mentions "Andaman" without other indication. The test of this specimen is not more than $8 \mathrm{~mm}$ in diameter. It is not in very good condition. It has been a little abraded. A portion of the test is broken on the ventral surface and on the sides. The test is colored slightly pinkish brown, but the spines are nearly colorless. The apical system conforms fairly well to the description and figures of Clark, especially the genital and ocellar plates. The periproct consists of a large semi-circular plate in contact with genitals 2, 3 and 4. Most of the periproct is filled by four small plates, longer than wide, forming a series between genital 2 and genital 5. The plates are wider and less high than in the figure of Clark. Those in contact with genital 2 are less regular than the others. The rest of the periproct, toward ocellars I and V and genital 1, is covered with some small plates. We can verify the arrangements that I just indicated in the photograph that I reproduce here, Pl. XVII, fig. 16.

I have not been able to thoroughly study this species that is extremely fragile. I must content myself with giving here these brief indications.

The type of G. metalopax studied by Clark and represented by a specimen whose test measures $17 \mathrm{~mm}$ and that comes from the Persian Gulf without other indication. 


\section{Gymnechinus pallidus nov. sp.}

(Pl. XVII, fig. 5, 13 and 15; Pl. XVIII, fig. 1 to 6; Pl. XIX, fig. 2 and 3; Pl. XX, fig.

Madras coast. - $20 \mathrm{fms}$. - Three specimens.

Station 204. - $6^{\circ} 01^{\prime}{ }^{\prime}$.; $81^{\circ} 16^{\prime}$ E. -34 fms. - Four small specimens.

Gregory Island, Mergui Archipelago. Six specimens.

Coast of Ceylon. - 32 and $261 / 2 \mathrm{fms}$. -A dozen specimens.

2 miles N. W. Great West Torres. - 40 fms. - Two specimens.

The diameter of the test varies in general around $15 \mathrm{~mm}$. It can reach $18 \mathrm{~mm}$ in the largest. It becomes smaller in some others and even falls to $6 \mathrm{~mm}$.

Here are some dimensions that I have taken from six specimens of different diameters, that I shall designate by the letters A to F.

\begin{tabular}{|c|c|c|c|c|c|c|}
\hline Specimens & $\begin{array}{c}\mathrm{A} \\
\mathrm{mm}\end{array}$ & $\begin{array}{c}\mathrm{B} \\
\mathrm{mm}\end{array}$ & $\begin{array}{c}\mathrm{C} \\
\mathrm{mm}\end{array}$ & $\begin{array}{c}\mathrm{D} \\
\mathrm{mm}\end{array}$ & $\begin{array}{c}\mathrm{E} \\
\mathrm{mm}\end{array}$ & $\begin{array}{c}\mathrm{F} \\
\mathrm{mm}\end{array}$ \\
\hline Diameter of the test. & 18 & 16.5 & 12 & 14 & 14 & 8 \\
\hline Height of the test $\ldots \ldots \ldots \ldots \ldots \ldots$ & 8.24 & 8 & 5 & 5.7 & 5.8 & 3.8 \\
\hline Apical system ....................... & $6 \times 5.2$ & $6 \times 5$ & $4 X 4$ & $4.3 \mathrm{X} 4.1$ & $4.2 \times 4.2$ & $1.6 \times 1.6$ \\
\hline Periproct …...... & $3.1 \mathrm{X} 2.4$ & $2.7 \times 1.2$ & $2.2 \times 2.3$ & $2.6 \times 1.8$ & $2.2 \times 2.3$ & $1.3 \times 1.2$ \\
\hline Peristome & 7 & 6.2 & 5 & 5.5 & 5.5 & 3.2 \\
\hline $\begin{array}{l}\text { Width of an ambulacral zone at } \\
\text { the ambitus ....................... }\end{array}$ & 5 & 4.2 & 3.2 & 3.8 & 3.8 & 1.6 \\
\hline $\begin{array}{l}\text { Width of an interambulacral zone } \\
\text { at the ambitious ..................... }\end{array}$ & 6 & 5.6 & 4.6 & 5 & 5 & 2.8 \\
\hline Length of primary spines $. . . \ldots \ldots .$. & $4.5-5$ & $4-4.5$ & 4 & 4 & 4.2 & 2.5 \\
\hline
\end{tabular}

I shall describe the species mainly after specimen B. Specimen A is a little larger, but its dorsal surface is slightly damaged and some plates are displaced.

The apical system is a little more elongated in the direction II-4 than in the direction III-5. (Pl. XVIII, fig. 4), except in individual C where it has nearly the same dimensions in all directions. The genital plates are, as usual, unequal. Plate 1 is the smallest, then comes plate 5 and finally the three other plates. The two plates 3 and 4 are elongated, one and a half times longer than wide, heptagonal, with a proximal border adjacent to the periproct shorter in plate 3 than in plate 4 and a distal corner. The opposite sides are very equal in plate 3 . They are a little larger in plate 4 that is also slightly shorter than plate 3 . The gonopore is near the top. Plate 2 is a little wider and shorter than plate 3 . It is asymmetrical. It has three borders of side III and only two of side II. It is contiguous with the periproct by a wide border than makes a narrow corner with the side that separates it from genital 3 and an obtuse corner with the adjacent ocellar II. The madreporite pores nearly cover the distal half of plate 2 up to the pore. They leave free all the proximal half. Plate 5 is hexagonal and very asymmetrical with a large border contiguous with the periproct. It is nearly as long as wide. Plate 4 is wider than long, pentagonal, quite symmetrical with a wide edge contiguous with the periproct, two very small lateral 
borders, much shorter than the side that limits the distal corner. The pore is located toward the middle.

Ocellar plates II and I are contiguous with the periproct. Plate I is nearly rectangular, much longer than high. Plate II is pentagonal, nearly as long as wide. These plates are very slightly larger than the three others, especially plate II. The three other plates are widely separated from the periproct. They are equal, pentagonal and a little wider than long.

The periproct is oval in the direction IV-1. It is covered with unequal plates, whose size decreases regularly from IV to 1, i.e., from left to right, the urchin placed being placed with ambulacrum II in front. The plates contiguous with genital 1 are numerous and extremely small. They surround the anus that is nearly marginal. A single plate, larger than the others, is always in the left part of the periproct, contiguous to genitals 3 and 4 . These plates are very slightly protruding. Their surface is shiny like glass. In specimen A (Pl. XIII, fig. 5), the characters of the apical system are nearly the same as in individual B.

It is especially in the large specimens that the apical system and the periproct are asymmetrical. In the small specimens, the periproct is nearly circular, but the genital plates are always very irregular. It can also happen that in specimens of average size, the periproct is also nearly circular. The inequality of the plates that cover it can also be less marked than in the other specimens. For example, in individual $\mathrm{C}$ whose test has a diameter of $12 \mathrm{~mm}$ (Pl. XVII, fig. 5, and Pl. XVIII, fig. 2, the periproct is barely oval in the direction I-3. The dimensions of these plates differ little. The plate that is contiguous with genitals 2 and 3 - usually much larger than the others - is not here much larger than the adjacent ones and the plates that cover the region around the anus remain likewise fairly large.

In specimen D whose test is $14 \mathrm{~mm}$ in diameter (Pl. XVII, fig. 13), the periproct is elongated in the direction III-5. Its plates are unequal and their dimensions decrease from region III to region V. The plate on side III is large and extends over the edge of the periproct. It is in relationship to genitals 2, 3, 4 and 5. The plates of the opposite region are very small. The four genitals 2, 3, 4 and 5 are all very elongated. Plates 2 and 5 touch the periproct by a large border. The two others by a much narrower border, especially for plate 3 whose proximal half is very narrow.

In specimen E, in which the diameter of the test is also $14 \mathrm{~mm}$ (Pl. XIX, fig. 3), the periproct is nearly circular. It is covered only by a small number of plates. The large plate covers nearly a third of the surface of the periproct. It is in relation with the genitals 2 and 4. Genital 3 is found outside. On each side are found other smaller plates. We then see still two more smaller plates. Finally, some plates of very small dimensions are found on both sides of the anus. Genitals 2 and 4 are very large. Plate 2 is nearly as wide as high. Plate 4 is a little higher than wide. These two plates are contiguous by a small border. Genital 3, notably smaller than it, is separated from the periproct. Genital 5 is small and short. Genital 1 is still smaller.

Finally, in the small specimen $\mathrm{F}$ whose test is only $8 \mathrm{~mm}$ in diameter, the periproct is elongated in the direction III-5. There is a large triangular plate contiguous with the two genitals 3 and 4. Then two other large plates, one of which contiguous with genital 5, is very wide. These four plates cover most of the periproct. The rest is filled with some 
unequal plates around the anus. Genitals 2, 3 and 4 are unequal. Plate 2 is always contiguous with the periproct by a wide edge (Pl. XVII, fig. 15).

The buccal membrane is thin and translucent. It has no plates other than the ten primary buccal plates, which are small, round or slightly oval (Pl. XVIII, fig. 3). We find in the thickness of the membrane very small C-shaped spicules, identical to those of the spicules of the tube feet.

The ambulacral plates, fairly short, have each a primary tubercle a little closer to the median suture than to the external border of the zone. These tubercles very protruding, increasing progressively in size to the ambitus. They decrease very slightly below it. Inside these tubercles, appear secondary tubercles at some distance above the ambitus. These tubercles, first a little irregular, form after the ambitus a fairly regular row that continues to the peristome. The arcs have each regularly three pore pairs. They are straight and fairly oblique.

I note in specimen A a slight anomaly in the ambulacrum IV (Pl. XIX, fig. 2). The majors 7, 8 and 9 of series $a$ do not have the usual form. Plate 7 is higher and the two following are shorter. Thee three plates have four primary tubercles a little smaller than the normal tubercles. Two of them are on plate 7 . The corresponding pores of these three plates are not arranged in regular arcs. They form a small group containing six pairs of pores that seem grouped into three regular arcs of two pairs each. Some of these pores are smaller than the others. On side $b$, the anomaly is less marked. However, plate 7 is higher than a normal plate. It has two tubercles that are a little reduced. There are four pairs of pores. The first three form a convex arc. The fourth pair is outside the alignment formed by the first three.

The interambulacral plates are high. Each has in its middle, but a little nearer the lower horizontal suture, a primary tubercle a little larger than the corresponding primary ambulacral tubercles. Some small secondary tubercles are seen here and there, but they are not numerous above the ambitus. Some of these tubercles very near the eternal border of the zone, two per plate, take very quickly a regular alignment and form a regular series in becoming larger. This series continues to the peristome. Other tubercles, only one per plate but larger than the preceding, also form a regular series very near the median suture.

The auricles are formed of two narrow and vertical apophyses that remain separate from each other.

The tube feet contain in their walls very fine C-shaped spicules with pointed ends, identical to those that Mortensen represented in G. versicolor (1904, pl. VII, fig. 24).

The spines are rather strong, but fairly short. Their surface is finely channeled longitudinally. These spines are white or very slightly tinted pink. The test has a general yellowish-gray or very pale pinkish-gray color.

The pedicellariae belong to the usual four kinds, tridactyles, ophiocephaloous globiferous and trifoliate (Pl. XXVII, fig. 4). The head of the tridactyle pedicellariae has a height of $0.4 \mathrm{~mm}$. The valves recall from some points of view those that Mortensen represented in G. versicolor (1904, pl. VII, fig. 30), with a very round blade at the end. This form differs for that which the same author saw in G. pulchellus (ib., pl. VII, fig. 29 ), where the blade is narrowed toward the end. The valves are strongly narrowed in their middle. But the basal part passes progressively to the blade without a very definite line of separation. The basal part is triangular and elongated. It is nearly as long as the blade. This, narrow at its base, enlarges progressively for nearly two thirds of its length, 
then its width decreases to form a very round terminal edge that has very fine denticulations (fig. $4 c$ ).

The valves of the ophiocephalous are 0.2 to $0.25 \mathrm{~mm}$ long. The triangular basal part is fairly wide at the base, but it is short and less sinuous and sometimes slightly lobed. The lower arcs are very developed (fig. $4 \mathrm{~b}$ ).

The valves of the globiferous pedicellariae are $0.3 \mathrm{~mm}$ long. The basal region is very enlarged, sometimes as wide as long. But often it is wider than long. Its height is equal to the width of the tube, or even exceeds it a little. The basal part continues without a welldefined line of separation with the tube. This, narrow, ends in a hook below which there is not the least trace of a lateral tooth (fig. $4 a$ ). This form of pedicellaria recalls hat which Mortensen represented in G. pulchellus (1904, pl. VII, fig. 8), but with a very enlarged basal part. The wall of the globiferous pedicellaria contains numerous $\mathrm{C}$-shaped spinules identical to those of the tube feet.

The valves of the trifoliate pedicellariae are approximately $0.12 \mathrm{~mm}$ long. The lower arcs are extremely short. The basal part is equally very low. The blade is very regularly round, sometimes it is even a little wider than long.

SIMILARITIES AND DifFERENCES. - G. pallidius appears to me very close to $G$. pulchellus that Mortensen described after the specimens from the Gulf of Siam. I do not believe, however, to be able to refer to this species the specimens of the INVESTIGATOR. In fact, the contours of the plates of the apical system are a little different in the two forms. Moreover, the spines are nearly colorless in G. pallidus, while they are red with white ends in G. pulchellus. I have compared my specimens to some specimens of G. pulchellus that M. Mortensen had the kindness to give me previously. I have seen the appearance is very different. In addition, the globiferous pedicellariae have the basal part more swollen in G. pallidus and the tridactle have a very different form. Finally, the spicules are pointed at the ends while those that Mortensen represented (1904, pl. VII, fig. 46) in G. pulchellus have enlarged and rounded ends.

In another species also described by Mortensen, G. versicolor that comes from the Macclesfield bank, the C-shaped spicules have two projections and the auricular apophyses are not united in an arc. The tridactyle pedicellariae have a form close but nevertheless different from that we find in G. palllidus, because the blade is much more elongated. It is, in fact, nearly three times as long as the basal part in G. versicolor, while in G. pallidus, this part is nearly as wide as the blade. The spines of G. versicolor have red and white rings with the lower part sometimes green, sometimes white.

A third species, also close to the two preceding, and coming from the Philippines, $G$. epistichus, was described by H. L. Clark in 1912. It is remarkable for the development of the primary tubercles. Its test is gray with a purple tint in the middle of each ambulacral and interambulacral zone. The primary spines are violet or pale red, with an indication of a wide violet band.

\section{Strongylocentrotidæ}




\section{Pseudoboletia indiana (Michelin)}

See for the bibliography:

Pseudoboletia indiana. Loriol, 1883, p. 28; pl. III, fig. 4.

Pseudoboletia indiana. Döderlein, 1888, p. 842; pl. XXXIII, fig. 8.

Pseudoboletia indiana. Mortensen, 1903, p. 118.

Pseudoboletia indiana. A. Agassiz and H. L. Clark, 1907, p. 246 (Bull. Mus. Comp. Zool., vol. $\mathrm{L}, \mathrm{n}^{\circ} 8$.)

Pseudoboletia indiana. H. L. Clark, 1914, p. 345; pl. XCII, fig. 12 to 18.

Pseudoboletia indiana. H. L. Clark. 1912, p. 345; pl. XCII, fig. 12 to 18; 1915, p. 98, and 1925, p. 131.

Station 204. $-6^{\circ} 01^{\prime}$ N.; $81^{\circ} 16^{\prime}$ E. -34 fms. - A single specimen.

The specimen is of small size. The diameter of the test measures only $25 \mathrm{~mm}$. Some of the spines are a nearly uniform brownish-red, the others nearly white or pink. The test lacking sines has a general background of plate pinkish-gray with irregular reddish patches.

I do not have particular remarks to add here regarding $P$. indiana other than that the single specimen in the collection is of very dimensions. I shall recall only that Mortensen has clarified the description that Agassiz gave of the pedicellariae and that H. L. Clark, in 1912, has again published detailed indications on its organs. I shall refer for a description to the memoirs of these two authors.

The Psammechinius paucispinus that Agassiz and Clark thought necessary to distinguish in 1907 is decidedly only the young form of Ps. indiana.

The species is essentially littoral. It does not descend below a depth of 100 meters. It is widespread in all the Indo-Pacific domain. It has been particularly reported at Madagascar, Mauritius, the Philippines, in the Bay of Bengal and at Ceylon, at Haiti, etc.

\section{Echinostrephus molaris $^{1}$ (Blainville)}

(Pl. XVIII, fig. 9 and Pl. XXVII, fig. 5)

Echinus molaris. Blainville, 1825, O, p. 88.

Echinostrephus molare. A. Agassiz, 1872-74, p. 119 and 457; pl. V a, dif. 10-12; pl. VI, fig. 20.

Echinostrephus molare. Stewart, 1880, 909; pl. XX, fig. 1 to 5.

Echinostrephus molare. J. Bell, 1881, p. 433.

Echinostrephus molare. Loriol, 1883, p. 31; pl. IV, fig. 2.

Echinostrephus molare. J. Bell, 1903, p. 247.

Echinostrephus molare. Mortensen, 1903, p. 128.

Echinostrephus molare. Meijere, 1904, p. 230.

\footnotetext{
${ }^{1}$ Several authors write molare. The word Echinostrephus being masculine, it seem to me more correct to write
} molaris. 
Echinostrephus molare. Rudmose Brown, 1910 a, p. 39.

Echinostrephus molaris. H. L. Clark, 1912, p. 342; pl. CV, fig. 10 and 11; 1925, p. 387.

Echinostrephus molaris. Lambert and Thiéry, p. 241.

Angrias Bank. - Three specimens and some debris.

Andaman Islands, MacPherson Strait. — Two specimens.

Andaman Islands, Port Blain. - Two specimens.

In the largest specimen from Angrias Bay, the diameter of the et is $20.5 \mathrm{~mm}$. In the smallest, it is only $9 \mathrm{~mm}$ and $7 \mathrm{~mm}$.

The species has been well described by the authors. Loriol added, in 1883, some remarks on the description of Agassiz. The photographs of the latter author and the more recent ones of H. L. Clark in natural size, do not show much detail of the test. The enlarged figures of Loriol (fig. $2 c$ and $2 d$ ) are more interesting. I believe it is necessary to reproduce here an enlarged photograph of the largest specimen from Angrias (Pl. XVIII, fig. 9).

I report this specimen all the more willingly because it has a small anomaly. The poriferous areas enclose very regularly three pore pairs, but in them, the two or three arcs that follow the first after the apical system have unequal pores. The two pores of the first pair are notably larger than the others. This is very regular in the five ambulacra. In principle, the two first pores of the second and third arcs after the apical system are much larger than those of the other pairs. The two first pores of the fourth arc, while being larger than those of the two other pairs of the same arc, are slightly small than on the two preceding arcs. In the following arc, the dimensions are regular and the pores all have the same dimensions that they keep to the peristome.

The pedicellariae, the spicules of the tube feet and the fenestrated plates of the buccal membrane were described in 1880 by Steward. He figured them correctly. Mortensen looked at them again. I reproduce here some photographs of the pedicellariae of three kinds, tridactyles, globiferous and ophiocephalous (Pl. XXVII, fig. 5).

The valves of the tridactyle pedicellariae are $0.8 \mathrm{~mm}$ in length on average. The basal part measures $0.12 \mathrm{o} 0.13 \mathrm{~mm}$. It is a little wider than long, with a slightly sinuous apophysis. The blade, first rather narrow, widens progressively into a spoon that narrows in the later third and ends in a blunt point. This spoon has in its terminal part some large denticulations, wide, short and obtuse. The perforations of the blade are rather small and not very dense. Those in the basal part are finer and denser. The lower arcs are very short (fig, $5 b$ ).

The valves of the globiferous pedicellariae have a total length of $0.4 \mathrm{~mm}$. Their round basal part is nearly half the total length of the valve. The tube is narrow. It has a terminal tooth with an unpaired lateral tooth (fig. $5 c$ ).

The ophiocephalous of the corona has a length of $0,33 \mathrm{~mm}$. The maximum width at the union of the lower arcs and of the basal region is $20 \mathrm{~mm}$. The basal region of the valves is nearly as long as the blade from which it is separated by a very distinct constriction. This blade has on its edge some wide and low denticulations (fig. $5 a$ ). The ohiocephalous of the buccal membrane are much shorter than the preceding. Their length is only $0.2 \mathrm{~mm}$.

The color of the test is pinkish-gray or violet-gray. The spines are purplish-red or dark violet-purple. 
Agassiz, in 1863, believed it necessary to distinguish an Echinostrephus found at the Hawaiian Islands and Kingsmills that he called E. aciculatus. But he united the two species in his Révision. To the contrary, H. L. Clark is of the opinion to separate them again. He characterizes $E$. molaris essentially by the poriferal arcs containing only three pairs of pores, by the genital and ocellar plates lacking tubercles or having them only on their borders, and finally by the more or less clear pentagonal contour of the test. While the E. aciculatus that the ALBATROSS found at the Hawaiian Islands has four pairs of pores in each arc, genital and ocellar plate have several tubercles on their surface, and finally, a test with a circular contour ${ }^{2}$.

E. molaris is fairly widespread in the Indo-Pacific domain. It has been reported at the Cape of Good Hope, Madagascar, Reunion, Mozambique, Natal, Zanzibar, and Kerimba, in the seas of India to the Society Islands, etc.

\section{Echinometridæ}

\section{Echinometra Mathcei (Blainville)}

(Pl. XVI, fig. 1 to 4 )

See for the bibliography:

Echinometra lucunter, Kœhler, 1895, p. 415.

Echinometra Mathai, Mortensen, 1903. P. 120, and 1904, p. 123-124/

Echinometra Mathai. Meijere, 194, p. 101.

Echinometra Mathai. Döderlein, 1907, p. 233-234/

Echinometra lucunter. R. Brown, 1910, p. 23, and 1910 a, p. 39.

Echinometra Mathai. Jackson, 1912, p. 147.

Echinometra Mathai. H. L. Clark, 1912, p. 372.

Echinometra Mathai. Lambert and Thiéry, 1912, p. 257.

Echinometra Mathai. H. L. Clark, 1923, p. 390.

Echinometra Mathai. Kœhler and Bonnet, 1924.

Echinometra Mathai. H. L. Clark, 1924, p. 390, and 1925, p. 143.

Nicobar Islands, without other indication. - One specimen of average size.

Andaman Islands. - One fairly large specimen.

Grand Cocos Island. - Two dry specimens.

Port Blair. - Two specimens.

Without indication of locality. - Four specimens of average dimensions and here other larger dry ones.

\footnotetext{
${ }^{2}$ In addition, Lambert and Thiéry, in 1914, considering that the first species has arcs with three pairs of pores and that the second contains four pairs of pores in each arc, place the latter among the Polypores. They thought that it was a matter of separating them generically. They kept the name Echinostrephus for E. aciculatus and created a special genus, Raphidechinus, for the species with three pairs of pores per arc. But in a verbal communication, Thiéry has informed me that Lambert and he think that the genus Raphidechinus cannot be maintained, the number of pores in each arc being decidedbly variable between three and four.
} 
Bushie (Cape Gilchist). — Four specimens.

The specimens from Bushire and the Nicobar Islands, as well as those whose locality is not indicated, have rather thin spines, elongated and a very dark purple. The large specimen from the Andaman Islands has very dark green spines, very thick in their first half and rather short. Finally, those of Port Blair and Grand Cocos Island have elongated and thick spines, but a very pale green color. The exterior appearance is thus rather different in the specimens. The individuals with pale green spines appear at first to be separate from those of Bushire. But they belong certainly to E. Mathoei, as we can easily be convinced by removing the spines from the test and examining the spicules of the tube feet with the microscope. We know moreover that similar variations are very common in E. Mathoei.

The diverse individuals in the collection of the Indian Museum belong to the form that is most widespread in the Indian Ocean. They are not in any way related to E. oblonga, as shown by the examination of the tube feet spicules. These spicules have, in the latter species, a very characteristic triradiate form that Döderlein did not hesitate to use to separate E. oblonga from the genus Echionometra and make it the type of a new genus, Mortensia, which has not been accepted by all zoologists. The character furnished by the spicules is moreover the only one separating at once the two species that are both seen in the Indo-Pacific domain, and that have certainly been mistaken for each other.

E. Mathai is a well-known form in the Indian Ocean. It has been studied by numerous authors. H. L. Clark remarked in 1923 how it was surprising that we do not have any good figure of this very widespread and very known species. I have thus believed it necessary to reproduce here some photographs of E. Mathoei, one from Madagascar and the other from the Bay of Bengal, both in my collection (Pl. XVI, fig. 1 to 4 ).

I recall that the auricles of E. Mathoei, like those of E. lucunter, are subject to considerable variations. I shall not return to this subject that I have studied with M. Bonnet fairly recently. I refer the reader to the work we published in 1924, in the "Bulletin de l'Institute Océanographique" ( $\left.{ }^{\circ} 446\right)$.

Echinometra Michelini L. Agassiz and Desor

(Pl. XVI, fig. 5 to 15 ; Pl. XVII, fig. 1 to 4,6 to 10 and 17 to 19$)$

Echinometra Michelini. L. Agassiz and Desor, 1846, p. 373, (p.69 from the reprint). non Echinometra Michelini. Lütken, 1864, p. 91; pl. I, fig. 1.

non Echinometra Michelini. Verrill, 1867, p. 369.

non Echinometra Michelini. A. Agassiz, 1869, p. 259.

non Echinometra Michelini. A. Agassiz, 1872-74, p. 116.

I believe it is necessary to make a special mention of E. Michelinni that belongs incontestably to the Indian Ocean and not to the Atlantic. The authors after L. Agassiz and Desor, such as A. Agassiz (1863 and 1872-74 and Verrill (1867), have considered incorrectly as synonymous the form more common to the Atlantic, E. lucunter, while Lütken in 1864 described, under the name E. Michelini, E. viridis. 
I know at the present seven specimens of E. Michelinni: four are found in the Jardin des Plantes, where they were labeled Echinometra oblonga, Nossi-Bé, Madagascar. Two others belong to $\mathrm{M}$. Thiéry, who very kindly communicated them to me. They authentically come from Madagascar. Finally, the last is found in my collection. It makes part of a lot of echinoderms from Madagascar that I bought earlier. The origin of $E$. Michelini is thus very certain. It is a form of the Indian Ocean. The indications furnished by Agassiz and Desor at the time, who mentioned as the locality Yucatan, and that of A. Agassiz who, in 1863, mentioned Florida and the Antilles, are completely erroneous.

These individuals are represented only by dry specimens, completely lacking their spines. In addition, in six of them, the apical system is completely lacking, i.e., the madreporite with the adjacent genital 3 and the ocellars II, III, IV. This individual is one of the two that belongs to M. Thiéry. We can thus easily orient and verify that the short axis of the test corresponds to $\mathrm{V}-2$ and consequently that the long axis corresponds to I3 as this is the rule in the genus Echinometra. But what is still more important, we can see that the plates of the apical system are covered with granules.

It is my specimen that is the largest. It measures exactly 38.5 by $31.5 \mathrm{~mm}$, while the larger specimen of M. Thiéry is $38 \times 31$. But this specimen has suffered abrasions that have a little altered the tubercles that are better preserves on the other individuals. The largest specimen of the Museum has also on the dorsal surface of ambulacrum II a partial alteration of the tubercles that appear to me due to a very energetic abrasion.

It is sufficient to glance at these specimens to be convinced immediately that they belong to a well characterized species, completely different from the common form of the Indian Ocean, E. Mathoei (Blainville) and the Atlantic form, E. lucunter (Linné). The primary tubercles have, in fact, considerable dimensions, so that the test takes a certain exterior resemblance to that of Heterocentrotus. The dimensions of the tubercles had previously struck L. Agassiz and Desor, who said of E. Michelini: "species close to E. lobata $^{3}$, but with tubercles much more developed, especially in the ambulacral areas. Five pairs of pores arched; two rows if primary tubercles in the interambulacral areas", (it is moreover to these lines that their description resumes). In addition, here are the characters that I have taken of the species that I have in my hands. I shall take as type the specimen that belongs to me, the two specimens of $\mathrm{M}$. Thiéry and the large specimen of the Museum. I shall designate respectively by the letters A, B, C and D.

$\begin{array}{lcccc}\text { Specimen } & \begin{array}{c}\text { A } \\ \text { In my } \\ \text { collection } \\ \text { mm }\end{array} & \begin{array}{c}\text { B } \\ \text { Thiéry's } \\ \text { specimen } \\ \text { mm }\end{array} & \begin{array}{c}\text { C } \\ \text { At the } \\ \text { Museum }\end{array} & \begin{array}{c}\text { D } \\ \text { Thiéry's } \\ \text { specimen } \\ \text { mm }\end{array} \\ \text { Length of test } & 38.5 & 37 & 35 & 32 \\ \text { Width of test } & 31.5 & 30.5 & 29 & 27.5 \\ \text { Height of test } & 22.5 & 22.5 & 21.3 & 20.5\end{array}$

\footnotetext{
${ }^{3}$ E. lobata or, if we prefer, lobatus de Blainville should be consider ed as synonymous with E. lucunter (Linné) of the Atlantic, because Blainville, in the Dictionnaire des Sciences Naturelles, says (V. XXXVII, p. 969) "that the test is convex above, that the arcs contain six and rarely five pairs of pores and that the auricles are elevated, with a very surcharged top, sometimes lobed on the borders". These indications do not correspond at all with those of the Catalogue raisonnée of Agassiz and Desor,,, who say of E. lobatus (p. 373) "species more or less depressed, pores spaced in arcs of six to seven pairs, etc..."
} 
Diameter of the peristome

Diameter of the periproct

Width of the ambulacral zone II at the ambitus

Width of the interambulacral zone 2
$16 \times 15$

$7 \times 6.5$

$16.2 \times 16$

$6 \times 4.6$

8

14
8

13
$15 \times 14.5$

$15 \times 14.5$

7

12
$15.5 \times 14.5$

$6 \times 4$

12

14

The three other specimens of the Museum are smaller. The length of their test varies between 31 and $27 \mathrm{~mm}$.

As I have said above, only a part of the apical system is preserved in individual D. The madreporite is rather small. Its contour is pentagonal. It has toward its proximal border, lacking pores, four small unequal tubercles, of which one is sensibly larger than the others. Two other finer tubercles appear toward its border contiguous with ocellar III. The opening is quite marginal as in genital 3. It has likewise a pentagonal contour. It has in its middle a larger tubercle accompanied by four other smaller ones. Plate II is longer than wide. It is larger than the others that are nearly as long as wide. Each ocellar plate has several tubercles, one central a little larger than the others that are at the periphery.

The primary tubercles acquire truly considerable dimensions relative to the size of the individuals. As in the large specimen A, the three and four primary interambulacral tubercles have a diameter of $2.5 \mathrm{~mm}$. The scrobicular circle is $3.4 \mathrm{~mm}$. These dimensions are not even reached in an E. Mathai from Madagascar, in which the test has a length of $50 \mathrm{~mm}$ and that is consequently much larger than the E. Michelini to which I compare it.

In specimen $\mathrm{A}$, the primary interambulacral tubercles number thirteen in series $1 b$. The first smaller, the second, much larger, is the dimensions a little less than the following tubercles that are the largest. The size decreases very slightly in the fifth and more in the sixth that is found at the ambitus. It is reduced very little in the following tubercles that go to the peristome.

In series $a$, the first primary tubercle, always counted from the apical system, has a slightly smaller size to that of the second tubercle of series $b$. The second, third and fourth tubercles have the same dimensions. The fifth is nearly equal to that of the preceding. Then the size decreases very slightly. The scrobicular circles are very wide. They cover most of the interradial plate. They are never, however, confluent. They remain separated by a row of very small unequal tubercles. They no longer appear between the circles of the two or three tubercles adjacent to the peristome. They remain localized on the sides of the tubercles. Outside the principal row of primary tubercles, between this row and the adjacent poriferous area, is another row of primary tubercles, always a little smaller than the preceding and which appears sometimes on the third interambulacral plate, but generally on the fourth. The tubercles of this row, ordinarily preceded by some small irregular and unequal tubercles, rapidly increasing in the dimensions, then decreasing very slowly below the ambitus. They alternate first with the tubercles of the principal row. Then they reach their correspondence near the ambitus. But this correspondence is not constant. Sometimes two of them correspond to one principal tubercle. On the other hand, the median interradial line has, between the principal primary tubercles, other tubercles smaller than those of the external row that merit the name of primary tubercles. They commence toward the third interradial plate. These tubercles do not follow a vertical row. They form a zigzag line. They are first very small, but their size then increases rapidly on the ventral surface. But they do not reach the peristome. The disappear at the level of the 
last two or three principal primary tubercles. All the rest of the surface of the plate remaining free between the primary tubercles is filled with unequal secondary tubercles, of which the larger are found toward the corners of the plates accompanied by some other smaller ones. Others appear between the scrobicular circles of the primary tubercles.

The primary ambulacral tubercles are smaller than those of the interambulacral zones. I count seventeen in each row. The tubercles alternate very regularly from left to right. The first two tubercles of each row are very small, sometimes arranged a little irregularly and, instead of forming regularly alternating pairs, we can find five more or less irregularly placed. The dimensions increase rapidly on the third tubercle. The maximum size is reached on the fourth. This size is maintained to the ambitus. Then it decreases very slowly to the peristome. A row of small secondary tubercles separates the successive scrobicular circles above the ambitus. This row progressively disappears below, without however the successive circles becoming contiguous. Some larger secondary tubercles occur toward the corners of the plates.

The poriferous zones are narrow. The pores form very regular arcs each with four pairs of pores, at least on the 0dorsal surface and on the sides of the body. In passing to the ventral surface, and in the area of the peristome, the number of pairs falls to three. They arrangements are regular in the large specimen of M. Thiéry. In the second specimen (D), most of the arcs have four pairs of pores but some have five, and a smaller number have only three. In my specimen A, that is the largest, I find on the dorsal surface some arcs with three pairs of pores only and one with five. I see likewise some arcs with three pairs of pores in the specimens from the Museum. The secondary tubercles are extremely near the poriferous zones. Often, but not always, one or two very small tubercles occur between the successive pore pairs.

I shall call particular attention to the modifications to the poriferous zones on reaching the apical pole in the seven specimens of E. Michelini that I have under my eyes. At some distance from this system, a distance that varies with the specimen, the two poriferous zones of each ambulacrum abruptly come very close together so that the proximal part of the ambulacrum is itself strongly narrowed. In this region, the poriferous zones themselves, not only cease to be in alignment in their respective zone but in addition, they often have diverse inflexions that are not symmetrical on each side. Other times, the two approaching zones follow a straight line. The pores are arranged very regularly in linear pairs one behind the other. It is rare that the pores have in these narrow parts irregularities or anomalies. Sometimes, however, we see the absence of some pores or the presence of single pores.

In specimen $\mathrm{A}$, the narrow parts are not very long. Their length varies between 3 and $5 \mathrm{~mm}$. Here are the modifications of these proximal regions. On ambulacra V and IV, the poriferous zones are nearly straight while on the three other ambulacra they are irregularly sinuous and zone $a$ of ambulacrum I is a little irregular at a centimeter from the apical system.

In specimen B, the proximal regions ae especially narrow in ambulacra IV and III where the poriferous zones remain nearly straight. But they are more or less sinuous in the three others (Pl. XVI, fig. 5).

In specimen $\mathrm{C}$, that is the smallest, the proximal regions of the ambulacra are narrow for a greater length. The narrowing is very distinct except on ambulacrum II. Some pores are missing in zone $b$ of ambulacrum III (Pl. XII, fig. 1). 
The narrowings are less marked in specimen D (Pl. XVI, fig. 6). But they are, to the contrary, very accentuated in the other individuals $\mathrm{E}, \mathrm{F}$ and $\mathrm{G}$. It is in specimen $\mathrm{F}$ that they are particularly apparent (Pl. VI, fig. 7)' Pl. XVII, fig. 2 and 3).

I do not want to describe in detail all the variations that can be see in the proximal regions of the ambulacra in the seven specimens that I have under my eyes. We shall have a good idea by examining and comparing the different photographs that I reproduce here.

In studying the proximal regions of the ambulacra in various species of Echinometra, we can also note some irregularities in the arrangement of the poriferous zones in the vicinity of the apical system. But these variations always remain very slight and cannot be compared to the arrangements that we encounter in E. Michelini. It would be very important to be able to study in a large number of species and to investigate if these arrangements are constant and if we can consider them characteristic of the species.

The auricles of E. Michelini are extremely developed. By their size as well as their form, they recall more those of E. lucunter (Linné) of the Atlantic than those of $E$. Matthai. They have, moreover, very curious variations that it is very interesting to note.

In specimen B, that is the large specimen of M. Thiéry, the five auricles each have a height of $8 \mathrm{~mm}$. They have a well-developed upper blade that has on their edges irregular and unequal small lobes. The two stalks ae nearly parallel to each other. The opening is elongated and round at the two ends (Pl. XVII, fig. 19). In the other individual D, of M. Thiéry, these auricles are smaller, comparatively thinner, and the upper blade is narrower. Its edges are smooth. The two apophyses are oblique and the opening is triangular ( $\mathrm{Pl}$. VII, fig. 18).

In my specimen $\mathrm{A}$, the two stalks of each auricle are oblique and shorter than in the two preceding individuals (Pl. XVII, fig. 6 to 10). The opening is triangular and well formed in the auricles of ambulacra II (fig. 7), III (fig. 8) and V (fig. 10), but it is very reduced in I fig. 6) and especially in IV (fig. 9). The blade that cover the auricle is generally very high but or irregular form. It has unequal and very irregular lobes on its edges. In auricle I, it is low and has a generally triangular form. In auricles II and III, it has on its free edge at one of the corners, a large asymmetrical lobe. In auricle IV, it is divided in part of its height by a deep cut that determines the formation of two hooked lateral lobes that intersect like that jaws of a forceps. Finally, in auricle V, the blade is narrower, triangular with smooth edges, except at the base where there are small lobes.

In individual $\mathrm{C}$ of the Museum, the auricles have a more regular form, with oblique apophyses and a triangular opening. The upper blade is nearly rectangular or a little widened however at the base in two lateral lobes. Its edges ae smooth (Pl. XVII, fig. 17).

The largest specimen from the Museum, E, has similar arrangements with slight variations in the form of the blade. It is the same in the small specimen whose length is $27 \mathrm{~mm}(\mathrm{~F})$, in which however auricle II has at its end a large lateral lobe similar to those I have reported above for auricles II and III of specimen A. But it is to be noted that in the small individual, the two stalks of the auricle, instead of being vertical, are very oblique outward and nearly reach the ventral surface of the test. Also, the blades that end them are very near the internal surfaces of the body. The muscles that are inserted on these auricles must have in the living an abnormal direction.

Finally, in the smallest specimen of the Museum, G, the auricles have completely abnormal forms (Pl. XVI, fig. 10 to 14). Only that of ambulacrum has nearly the usual form with an opening moreover irregular (fig. 10). In the others, the blades are shorter, 
triangular and irregular. The stalks themselves are widened with the edges slighted lobed. The interradial portions that connect them are themselves higher than usual. The photographs that I reproduce here (fig. 10 to 14) allow me to dispense with giving a detailed description of the form of these auricles.

These variations in the characters of the perignathic girdle recall those that I have indicated in E. Mathoi. The description that I have given above and the photographs that accompany it indicate how the characters of E. Michelini differ from those of E. Mathai $i$. It is, nevertheless, with the latter that the species must be compared because of the arrangement of the poriferous zones.

The type of the true E. Michelini is thus represented by the four specimens of the Museum. The Echinometra that Lütken described in 1864 (p. 91, pl. I, fig.1) under the name E. Michelini is compleely different from it. It is E. viridis, an essentially Atlantic form. The specimens that Lütken had in his hands came from the Danish Antilles and Porto Cabello. The description and the figures of Lütken leave no doubt about their determination. Among others, the arcs with five pairs of pores and especially the plates of the apical system that completely lack tubercles, have the arrangements completely characteristic of E. viridis. In his Révsion (p. 116 and 283), Agassiz still cites E. Michelini as synonymous with E. subangularis (Leske) in indicating as coming from Yucatan. Florida, and the Antilles, but he adds (p. 116) after the name E. Michielini... non Lütken", while among the synonyms of $E$. viridis he indicates $E$, Michelini Lütken 1864, adding ... "non Desor nec. A. Ag.".

The question of the value of E. Michelinni appears thus very fluid. The true $E$. Michelini, whose type is in the Jardin des Plantes, is essentially a form of the Indian Ocean. Authors who have mentioned it in the Atlantic have confused it with one or the other species of this latter ocean, E. subangulais (Leske) $=$ lucunter (Linné) and $E$. viridis. Agassiz.

\section{APPENDIX}




\section{Deformations provoked in some Cidaridæ by parasitic Prosobranchs}

I have seen, in various specimens of Dorocidaris tiara and Stereocidaris indica, parasite prosobranchs whose presence results in deformations and very curious anomalies in these echinoids. It appeared interesting to me to study this in some detail.

In Dorocidaris tiara, the parasites are attached to the base of a spines, without doubt at a very early stage of development. They have provoked in it a very apparent deformation. The spines remain very short. Most of the time, its total length does not exceed one centimeter. In contrast, it is very thick. It is transformed into a kind of curious gall, open at its free end and in which is lodged the parasite. The test proper remains perfectly normal.

In Stereocidaris indica, in contrast, the parasite is attached directly to the test. It inserts its proboscis across the calcareous wall into the body of the urchin, utilizing, it seems, a tube foot pore. The presence of the parasite leads to extremely profound anomalies in the test of the urchin.

The parasitic prosobranchs of Dorocidaris tiara and Stereocidars indica both belong to the family Eulimidæ. They must be placed in the genera Metadenus and Mucronalia, very close to each other.

\section{Dorocidaris tiara}

(with spines deformed by a prosobranch)

(Pl. XXI, fig. 8, 9 and 11, and Pl. XXII)

The prosobranch parasites that I have observed in Dorocidaris tiara belong to the genus Megadenus, and, as I just said, these gastropods attached at the base of a still very young spine, have provoked in the latter a considerable deformation. I have encountered, among the D. tiara of the collection, four specimens thus parasitized. One has only a single parasite, but the other three each have several. I reproduce here photographs of three of these individuals (Pl. XXII, fig. 1 to 3 ) and the fourth specimen with a single parasite (fig. 4), as well as photographs more magnified of various spines with their parasites (Pl. XXI, fig. 8, 9 and 11; Pl. XXII, fig. 5 to 16.

I first reported this prosobranch to the genus Mucronalia, but a study more complete, done with my colleague M. Vaney, showed us that it should be placed in the genus Megadenus. 
We published in 1925, M. Vaney and I, a note on these urchins. I can only reproduce here the principal parts of our work ${ }^{4}$.

The modifications of the spines are fairly variable. Generally, the spine is reduced to its basal smooth part, which is more or less swollen. above the cone of articulation. It takes the appearance of a kind of hollow gall, of variable form, often irregular, and brownish in color. The articulating collar of the spines remains very visible and striated. The height of the part modified into a gall ranges between 4 and $6.5 \mathrm{~mm}$. The greatest diameter of the swollen part varies between 3 and $5 \mathrm{~mm}$.

Some of these galls are widely open toward their upper part. These have a cup-shaped aspect, but the contour of the opening is nearly always irregular. Other swellings open laterally by a more or less narrow opening. Among the latter, we see some whose swollen part is surmounted by a short stub, arranged sometimes eccentrically and constituted by a grooved portion of the spine.

Most of these galls harbor, in the interior of their lodge, a small prosobranch of which we see the top of the shell very well, ending in a small mucron. These are the most developed galls. The less deformed spines have generally reduced lodges with no guest in the interior.

The wall of the galls is very thick. Its thickness reaches 1.5 to $2 \mathrm{~mm}$. It is constituted mainly by a hypertrophy of the calcified tissue of the spine that gives it a very great rigidity. It encloses a central cavity, a kind of more or less spherical lodge, whose diameter varies from 2 to $30 \mathrm{~mm}$.

The guest that we see in the lodge is a mall prosobranch $2 \mathrm{mmm}$ in length whose whitish porcelain shell has six whorls. This shell is thin and very fragile. The diameter of the last whorl is $2.3 \mathrm{~mm}$. The top of the shell is a mucron barely $0.4 \mathrm{~mm}$ in height and $1 / 3$ millimeter in diameter at it base. It is formed by the first three whorls of the spire. The three last three whorls of the spire are much more swollen, especially the last and the next to the last. Their growth lines are very marked.

The prosobranch removed from its lodge has a very large proboscis more than a millimeter in length. It is surrounded at its base by a kind of collar or pseudo-pallium covering in large part the flange of the shell. We see a very reduced cephalic region and a small foot that does not have an operculum. In the same lodge, we find beside this adult individual, another specimen of very small size with a length of a millimeter and, in addition, a whole series of more or less spherical capsules, approximately $1 \mathrm{~mm}$ in diameter and each containing twenty to twenty-five eggs.

Microscopic examination allowed us to establish that the large individual is a female while the small one is a male. Both are mature and live side by side in the same gall.

Here is thus very clear sexual dimorphism, the female being three times higher than the male. In addition, the male has a thin shell whose last whorl, the most swollen, is 0.5 $\mathrm{mm}$ in diameter, and with the preceding narrower whorl, make together a kind of fairly strong mucron. In the male the proboscis is more massive and less projecting than in the female. The pseudo-pallium is very developed, with irregular contours. It covers most of the shell in the female.

The microscopic study permitted us to detect a pair of pigmented eyes of small size, more or less sunken into connective tissue. The nervous system is very condensed, although the various ganglia are fairly distinct. Toward the pedal ganglion is a pair of

\footnotetext{
${ }^{4}$ Comptes-Rendus de l’Académie des Sciences de Paris, May 1925.
} 
otocysts. The foot is very reduced. It contains a very apparent superimposed gland and a correctly called foot gland. There is no radula. The pallial cavity is widely open and contains a well-developed gill.

The eggs contain a large amount of yolk.

This mollusc belongs to the family Eulimida. With its shell provided with a mucron made up of the first whorls of the spire, it is in the group comprising the genera Pelseneeria, Mucronalia, Megadenus and Stilifer. The absence of an operculum, the presence of a pseudo-mantle of cephalic origin, the presence of a rudimentary foot containing a well-developed pedal gland and very accentuated sexual dimorphism lead us to consider it a new species of Megadensus for which we propose the name cysticola.

The genus Megadenus was established by Rosen in 1910 after a new species of parasitic prosobranch, Megadenus holothuricola, that he observed fixed by its proboscis to the respiratory trees of some Holothuria mexicana Ludwig of the Bahama Islands. A second species, Megadenus Voeltzkow Schepman and Nierstrasz (1913), was found by Voeltzkow, fixed to the coelomic side of the pharyngeal ring of a holothuroid of Zanzibar, probably Holothuria pardalis Selenka. These two species of Megadenus, although having the morphological characters of ectoparasitic prosobranchs, have instead an endoparasitic life. Our new species, which lives enclosed in a gall communicating with the exterior, has conditions of life comparable to that of the other Megadenus.

In Megadenus holothuricola and Voeltzkowi, the male and female are also found side by side. They are distinguished from each other by the differences in size and the well characterized anatomical arrangement. As in M. holothuricola, the male has a shorter proboscis than the female, while its pseudo-pallium is more developed. It covers most of the shell, and in the pseudo-pallial cavity thus enclosed, is found the mass of eggs. Our new species has a dimorphism still more accentuated. The male is very much smaller than the female from which it is distinguished moreover by other characters.

We have already reported a similar dimorphism in another species of ectoparasitic prosobranch, likewise discovered by the INVESTIGATOR, Thyca stellasteris. This results in a very marked sexual dimorphism that is found in two very different series of ectoparasitic prosobranchs: Capulida with Thyca stellasteris and Eulimida with Megadenus and more specifically with $M$. cisticola, The latter fact is particularly interesting because the Eulimidae are attached to the Entoconchida or endoparasitic prosobranchs by our Gasterosiphon deimatis. Now, Schwanwitch (1917) discovered in a form of Enteroconchida, Entocolax Ludwigi Voigt, dwarf and rudimentary males. These males are barely $0.5 \mathrm{~mm}$. They are globulose and strongly reduced because, under their integument, we find only a rudimentary intestine and a voluminous testis with a canal deferens. Schwanwitch was able to follow the metamorphosis of the veliger larva, with a fairly complex structure in the rudimentary male. These dwarf males have been found in the incubatory or pseudo-pallial cavity of individual female Entocolax Ludwigi measuring about a dozen millimeters in length. The organization of these females, although profoundly modified by endoparasitism, is much less than that of the male, because we still find in it a digestive tube with esophagus and intestine, a kidney, an apparent gonadal system with an ovary, oviduct, seminal receptor and uterus, as well as a nerve ganglion accompanied by a pair of otocystes.

The sexual dimorphism seen in Megadenus represents thus a first step in a series where the ultimate stage is that of Entocolax Ludwigi with dwarf and rudimentary males. 
Remarks made by Kükenthal (1897), as well as by Schepman and Nierstrasz (1900), show dimorphism in some Mucronalia. Nierstraz (1909) found in the pallial cavity of Stilifer siboga Schepman and Nierstrasz, a pedogenetic larval form having mature sperm and that could have been a dwarf male.

Deformations of the spine of Cidarida under the influence of prosobranchs have already been reported. In 1860, Hupé described a new species of Stilifer, S. orbignyanus, that had transformed two spines of a Phyllacanthus imperialis (Lamarck), coming from New Zealand, into globular, irregularly spheroidal formations. These kinds of galls, having the appearance of nuts, have at their base small openings in the form of slits. These would make a cavity in relation to the exterior an internal cavity one centimeter in diameter, in which were found two shells of adult Stilifer 5 to $6 \mathrm{~mm}$ in length, surrounded by some small shells. It is very probable, as Hupé thought, that the two adult individuals were the male and female of the same species surrounded by their progeny.

Rathbun (1885) reported perforations and protuberances in the spines of Eucidaris tribuloides that were due to a Stilifer. In the variety africana of the same species of urchin, Mortensen (1910a) observed and figured three specimens of a Stilifer attached to a spine and provoking a growth in the form of a gall that opened widely to the exterior, In the cavity of this were lodged the parasites with their spawn.

It would be interesting to find and study again the different Stilifer to see if they are not related to the genus Megadenus. It does not seem that the authors who reported them were struck by a dimorphism of the individual adults.

\section{Stereocidaris indica}

(with the test deformed by a prosobranch)

\section{(Pl. XIX, fig. 5 to 11 ; Pl. XX, fig. 1 to 9; Pl. XXI, fig. 1 to 7 and 10)}

Stereocidaris indica can, like Dorocidaris tiara carry parasitic prosobranchs on its test. But in it, these molluscs are attached directly to the wall of the test that they perforate, and no longer at the base of the spines. They provoke in the animal to which they are attached, very profound deformations that affect the arrangement of the plates of the test itself.

The collection of the INVESTIGATOR contains five specimens all coming from station 333. They have deformations caused by the parasitic molluscs. But these latter, attached to the test, in a way not very firm, have not always been preserved in place.

It is thus in my preliminary memoir of 1922 on the "Anomalies and Irregularités du test chez les Échinidés." (Bulletin de l'Institiut Océanographique $n^{\circ} 419$ ), I had the opportunity to describe a first specimen of St. indica whose test had, at the moment when I studied it, no longer the slightest parasitic prosobranch. However, after have described it and in investigating the causes that had produced in it the irregularities that were so varied and profound, I suggested that perhaps an external parasite, without doubt a prosobranch, had provoked by its presence the depression in one of the tube feet below the ambitus, but that the parasite had been previously detached from the test.

Now, in reviewing all the Stereocidaris indica in the collection of the Indian Museum, I was very happy to find first two new specimens with anomalies similar to those of the individuals described in 1922, and like it, had no trace of the external parasite. 
But, what was much more interesting, I encountered two other individuals that had each two prosobranchs. These were attached near the ambitus or below, precisely at the level of a tube foot and making a depression in the test, a kind of niche in which they were lodged with some spawn. Two of these prosobranchs had their shell more or less broken, but the other two were nearly intact. It was easy to be assured that they belonged to the genus Mucronalia. I reproduce here two photographs of these parasitic individuals to show the position the prosobranchs occupy on the test, as well as some larger views of the parasites themselves, then various views of abnormal tests (Pl. XIX, fig. 5 to $11 ; \mathrm{Pl}$. XX, fig. 1 to 9; Pl. XXI, fig. 1 to 7 and 10).

I must note that the prosobranchs are not attached in a very firm manner. The two parasites of one of the two specimens were detached under the sole influence of the movements that I made on the test to raise the adjacent secondary spines. The parasites remain in place in the other individual. It is incontestable that the specimen that I described in 1922 and two new ones that, like it, do not have the parasites now, had them at one time and that these are the cause of the more or less deep anomalies in the test. The parasites were detached at a time when the urchins suffered shocks during dredging or when they were placed in containers. As I indicated in 1922 and as we shall see later in studying these different abnormal individuals, there is always a more or less marked depression near a tube foot. It is in this depression that the prosobranch must have been found or is still found. We can suppose, in fact, that they chose a tube foot as the site for their attachment, to utilize the pre-existing perforation that the tube foot pore offered them, in order to insert their proboscis into the body of the animal. The depression provoked by the parasites are not very deep. They remain perfectly visible from the exterior as we can see in Pl. XXI, fig. 4 and 7.

I had proposed to describe in detail these five St. indica in the present memoir what had been written in 1922. But as the publication of this memoir was delayed and I believed it would continue to be delayed, I was led to study these five specimens in the memoir that I devoted to "Anomales, Irrégularités et Déformations du test chez les Échinides" (Annales de l'Institut Océanographique, nouvelle série, Tome I, p. 159-480, avec atlas de 32 planches, 1924).

It seems useless to reproduce here the rather long and very detailed descriptions that I gave in that work. I ask the reader to please refer to it. I shall content myself to summarize briefly here the characters of these five abnormal St. indica and reproduce some photographs of each of them.

I have designated these abnormal specimens by the letters A, B, C, D and E. The first three are the specimens in which the parasitic prosobranchs no longer exist. The two latter are those in which the parasites are still in place ${ }^{5}$.

\section{Specimen A}

\section{(Pl. XXIX, fig. 5 to 10$)$}

\footnotetext{
${ }^{5}$ I shall add that Döderlein reported in his memoir of 1907, in which a form very near to St. indica, St. Alcocki (that he called tricarinata) var. teretispina, the presence of five prosobranchs that he referred to the genus Stilifer, and that, to judge from the photograph that he reproduced in pl. X, fig. 7 a, seems to me to be Mucronalia. Döderlein has not studied the anomalies provoked by these prosobranchs in the parasitized urchins.
} 
This individual has a very considerable deformation of ambulacrum I above the ambitus. Its apical system in deformed. It has, in addition, various irregularities in other regions of the test.

The test is nearly circular. The diameter measured following direction V-2 is $46 \mathrm{~mm}$. The test is flat in the region located to the right of line $\mathrm{V}-2$ where its height ends by falling to $27 \mathrm{~mm}$, while it is $35.5 \mathrm{~mm}$ in the opposite region. Immediately outside the apical system, the test has a very projecting bulge involving radius I and the corresponding parts of the two adjacent interradii. This bulge, which is easily recognizable in the photographs that I reproduce here (fig. 7 to 10), is separated in its lower part from the rest of ambulacrum I by a fairly deep depression.

The apical system no longer has the form of a regular polygon but is elongated in the direction I-3. We would hesitate to trace its edge toward genital plate I that is fragmented and deformed. Part of the plates of the apical system have kept their normal form. These are genitals 1 2, 3 and 4 and ocellars III, IV and V. The others are more or less deformed and fragmented. Ocellar plate II is strongly widened toward genital I. It is certainly fused to a detached portion of the latter. Ocellar plate II remains small and irregular in form. Genital plate 5, instead of being pentagonal, is clearly triangular and asymmetrical. But it is especially genital plate 1 that has the important modifications. It is present as a small plate having the form of a triangle or a square on which the pore is near the distal border.

Because of the deviations of some ambulacral zones in their dorsal region, the interradial zones do not keep the same width in approaching the apical system. It is notably radii I, IV and V that are more or less strongly inflected and interradii 2 and 1 and especially 5 that are considerable widened.

Radius I is strongly modified above the ambitus. Toward the point of its path that corresponds to the distal or lower border of plate $2 b$ of interradius 5 , it abruptly widens and then narrows at the same time that it is depressed. But it rises rapidly before reaching the level of the bulge that I just reported. In this path that measures approximately $8 \mathrm{~mm}$, the plates and the pores have irregular granules. Beyond it resumes a little its normal characters in continuing to the apical system without having another modification other than a very marked inflection to the right toward interradius 1and a slight narrowing as a whole.

\section{Specimen B}

(Pl. XIX, fig. 11; Pl. XX, fig. 1 to 4$)$

The individual is a little larger than the preceding. As in it, radius I is profoundly modified. It must have had one or two parasites in the living animal. The diameter of the test, measured following direction I-3, is $46 \mathrm{~mm}$. It is only 44 following II-4. The periproct is strongly ovoid and very elongated. The apical system is also asymmetrical. These two systems are elongated in the same direction as the test. Seen in profile, i.e., by ambulacrum II or by ambulacrum V, the test has a very irregular contour. It is very elevated in region II, 3 and IV, very lowered to the contrary from side 5, I and 1. There is in addition in the dorsal region of radius II and the adjacent part of 1, a very marked bulge, 
while in the region diametrically opposite, and always on the dorsal surface of the test, we see a very limited depression that involves the terminal part of radius IV side $b$ and the adjacent region of interradius 4 . When we look at the profile of the test by radius I, we see that the contour does not follow a regular curve to the right and to the left, i.e., at the level of ambulacral zones V and II. From the left side (V), the direction of the curve changes a little above the ambitus as a result of some flattening of the test. The dorsal region makes an obtuse angle with the lateral surface. From the right side, i.e., from side II, this angle that is at some distance above the ambitus is still more accentuated. It is nearly straight while being rounded. It results in this fairly marked bulge that I reported above. This flattening of the dorsal surface of the test is still present on radius III. The dorsal surface passes to the lateral surface by a round, obtuse angle. Finally, the two ambulacra II and V have a very clear curve in their terminal part. Not only is radius I strongly curved toward its end, but the two poriferous zones become nearly indistinct above the ambitus. The pores are fused with each other in part or they have even completely disappeared.

If we compare this individual to the first abnormal specimen A we see, among the irregularities that they both have, some similarities. In fact, in both the apical system is larger than usual and it is elongated in the direction I-3. Ambulacral zones II, III, IV and $\mathrm{V}$ have similar forms in their direction. Radius I keeps its normal characters on the ventral surface and at the ambitus. Above the ambitus, its two normal series of pores stops. They, abruptly disturbed in their form and appearance, form a profoundly modified region that, in individual B, continues to the apical system. This remains shorter in specimen A. The adjacent interradii 1 and 5 are also more or less modified.

\section{Specimen $C$}

\section{(Pl. XX, fig. 5 to 8$)$}

Individual $\mathrm{C}$ is slightly smaller than the preceding. Its test is a little oval. It is in fact slightly elongated following direction IV-1, where its width is $42 \mathrm{~mm}$ while, in the perpendicular direction, it measures only $39 \mathrm{~mm}$. The apical system has become irregular, mainly due to the exaggerated development of genital 5 that advances considerably in the corresponding interradius. The four ambulacral zones III, II, I and V are nearly normal, but radius IV exists only on the ventral surface of the test. It is abruptly interrupted at the ambitus where it is replaced by an elongated and fairly marked depression that extends to a short distance from the suture separating genital plates 3 and 4. It is in this depressed region, above the point where the tube foot pores cease their regular arrangememt, that are found the parasitic prosobranchs. The depressions that they provoke at the surface of ambulacral zone IV causes profound modifications in the arrangement of the plates of interradii 2 and 3 of the dorsal surface of the test.

Without going into a detailed description of the anomalies in specimen $\mathrm{C}$, for which I refer to my memoir of 1924, I shall content myself with saying that in comparing this specimen to the two preceding individuals, we note that the elongation of the test is made likewise in it in the direction IV-1, but that it is radius IV that is profoundly abnormal. It stops, like radius I of the two first specimens A and B, at the ambitus. But unlike these 
two where there remains on the dorsal surface of the test some very recognizable remains of this radius, especially in individual $\mathrm{A}$, the dorsal region of radius IV is reduced in specimen $\mathrm{C}$ to scarcely distinct or nearly no vestiges. There is at this level, a very apparent depression in specimen $\mathrm{C}$ that is less developed in specimen $\mathrm{A}$ and still less in specimen B.

\section{Specimen D}

\section{(Pl. XX, fig. 9; Pl. XXI, fig. 1 to 4 and 6)}

Individual D has above the ambitus and on ambulacrum II, two prosobranchs located on both sides and nearly at the same height. On the animal with its spines, the two parasites are in part hidden by them. They appear lodged in a small depression of the test. Beside them, we can recognize some of the very voluminous spawn. One of the prosobranchs is intact. Is shell measures $3.5 \mathrm{~mm}$ in height with a maximum width of 3 $\mathrm{mm}$. The exterior characters of the shell allow confirmation that these prosobranchs belon to the genus Mucronalia.

In removing the spines from the test, we see that the parasites have provoked the formation of a simple depression, not very deep and little extended, less important than we would have been able to believe in looking at the urchin with spines. This depression involves radius III and encroaches on adjacent interradius 2. Also, this specimen has a very accentuated anomaly on radius III and adjacent regions of interradii 2 and 3 . What makes these anomalies interesting is that we can relate with certainty the presence of the parasitic prosobranchs attached to a certain region of the test, as we see likewise in the fifth specimen E.

Specimen D is nearly the same size as C. Its contour is circular. The diameter is 41 $\mathrm{mm}$. The apical system is a little elongated following direction III-5. The periproct is likewise elongated in the same direction. Genitals 2 and 3 are only a little wider than usual. The three others are not modified. Ocellar III appears to be lacking or rather it has been deplaced toward the end of radius III at the same time that it becomes rudimentary. Radius III has a very large anomaly. It is in fact interrupted above the ambitus. This interruption is seen for a length of $3 \mathrm{~mm}$ that corresponds to the place of attachment of the two parasitic Mucronalia. After this interruption, the radius appears again on the dorsal surface of the test, but in a reduced form with rudimentary, badly placed pores. It has characters similar to those that we see in ambulacrum I of specimens A and B. Interradii 2 and 3, adjacent to radius III, likewise have large irregularities. If we compare this specimen to individuals $\mathrm{A}$ and $\mathrm{B}$ that have, like it, a dislocation of a radius on which were incontestably attached the parasites, we see in the latter the anomalies were more numerous and more marked. The modified radius was radius I, but in specimen A it had a profound depression that was accentuated by the fact it is surmounted by a very marked bulge, while, to the contrary, the depression is less important in dividual B. This is precisely what happens in individual D. The same apical system is less deformed in D than in the two first individuals. 


\section{Specimen $E$}

(Pl. XXI, fig. 5, 7 and 10)

It has not been possible to a give a description of the test of this individual as detailed as that I have been able to make of the four preceding individuals because I wanted to leave in place, at lease in this individual, the two parasites as well as the spawn that is with them. It is on radius II that the Mucronalia are attached. They have made with their spawn a very deep depression that is widened transversally and that measures approximately $10 \mathrm{~mm}$ in width. In a general way, the anomalies of the test are mainly in radius II and the two adjacent interradii. We can note, however, some other irregularities. Thus, the contour of the test is not exactly circular. It is elongated in the direction II-4 after which the diameter measures $14 \mathrm{~mm}$ while it is only $38 \mathrm{~mm}$ in the perpendicular direction. The periproct is also elongated in the same direction as the test. Genital plates 2 and 3 are a little elongated. In addition, they are contiguous with each other. There is no ocellar III. Radius II slightly passes the ambitus. Then it disappears suddenly $2.5 \mathrm{~mm}$ below the depression lodging the two Mucronalia, without any modification preceding this disappearance. The radius disappears purely and simply but it does not reform beyond it. The two interradii 2 and 1 are contiguous with each other below the area where radius II has disappeared so that they alone form the dorsal surface of the test in this region.

It is very curious to see that the test of this individual $\mathrm{E}$, in which the depression formed by the two parasites in ambulacrum II is more marked and deeper than in any of the four other specimens, has, however, fewer abnormalities and irregularities than those that we have seen in these four latter individuals. 


\section{LIST OF CITED WORKS}

Agassiz, A. 1863. Preliminary Report on the Echini... deep water... Florida Straits. Bull, Mus. Comp. Zool. Vol. I. Cambridge.

Agassiz, A. 1872-74. Revision of the Echini, Ill. Cat, Mus. Comp. Zool. at Harvard College. $\mathrm{N}^{\circ}$ 7. Cambridge.

Agassiz, A. 1881. Reports of the “CHALLENGER”. Zoology. Vol. III. Echinoidea. London.

Agassiz, L., and Desor, E. 1846-47. Catalogue Raisonné de la classe des Échinodermes. Ann. Sc. Nat. Zool. (3), T. 6, 7 et 8.

Agassiz, A., and Clark, H. L. 1907. Hawaian and other Pacific Echini. The Cidaridæ. Mem. Mus. Comp. Zool. Vol. XXXLV, ${ }^{\circ} 1$.

Agassiz, A., and Clark, H. L. 1908. The Salenidæ, Arbaciadæ, Aspidodiaematidæ and Diadematidæ. $I b . \mathrm{n}^{\circ} 2$.

Agassiz, A., and Clark, H. L. 1909. The Echinothuridæ. $I b . \mathrm{n}^{\circ} 3$.

Alcock, A., and Anderson, A. R. S. 1895. Illustrations of the Zoology of the steamer "INVESTIGATOR". Echinoderms. Calcutta 1895.

Anderson, A. R. S. 1894. Natural history from steamer "INVESTIGATOR". Echinoidea. Journ. Asiatic Soc. of Bengal. Vol. LXIII, part II. $\mathrm{n}^{\circ} 3$.

Bell, F. Jeffrey. 1881. Observations on the caracters of Echinoidea. IV. The Echinometridæ. Proc. Zool. Soc. London. 1881, part 2.

Bell, F. Jeffrey. 1903. Report on a collection of Echinoderms of Zanzibar. Ann. Mag. Nat. Hist. (7), Vol. 12.

Blainville, H. M. 1825. Dictionnaire des Sciences Naturelles. T. XXXVII. Paris

Blainville, H.M. 1834. Manuel d'Actinologie. Paris.

Clark, H. L. 1907. The Cidaridæ. Bull. Mus. Comp. Zool. Vol. LI, n ${ }^{\circ} 7$.

Clark, H. L. 1908. Some Japanese and east Indian Echinoderms. Ib. $\mathrm{n}^{\circ} 11$.

Clark, H. L. 1912. Hawaian and other Pacific Echini. Mem. Mus. Comp. Zool. Vol. XXXIV, $\mathrm{n}^{\circ} 4$ (The Pedinidæ, Echinidæ... and Echinometridæ).

Clark, H. L. 1923. The Echinoderm Fauna of South Africa. Ann. South African Museum. Vol. XIII.

Clark, H. L. 1924. Echinoderms from South Africa: part I, Sea-Urchins. Fisheries and Marine Biological Survey. Report $\mathrm{n}^{\circ} 4$.

Clark, H. L. 1925. A catalogue of the recent Sea-Urchins in the British Museum. London.

Döderlein, L. 1887. Die japanischen Seeigel. Teil I. Stuttgart, 1887.

Döderlein, L.1888. Echinodermen von Ceylan. Zoolog. Jahrb. Bd. III. Abtheil. f. systematik.

Döderlein, L. 1901. Diagnose einiger von der Valdivia-Expedition gesammelten Seeigelarten, Zool. Anz. Bd. XXIII, p. 19.

Döderlein, L. 1902. Bericht über die von Semon bei Amboina and Thursday-Island gesammelten Echinoiden, in: Semon, Forschungsreisen. Jen. Denkschrift. Bd. VIII. 
Döderlein, L. 1905. Ueber Seeigeln der deutschen Tiefsee-Expedition. Zool. Anz. Bd. XXIII, p. 621.

Döderlein, L. 1907. Die Echinoiden der deutschen Tiefsee-Expedition. Deutsche TiefseeExpedition. Bd. V.

Döderlein, L. 1911. Ueber Echinoidea von den Aru-Inseln. Abh. der Senckenberg. Naturf. Gesellschaft. Bd. XXXIV.

Dujardin, F. and Hupé, H. 1862. Histoire naturelle des Zoopohytes. Échinodermes. (Suites à Buffon).

Herdman, W. A. 1904. Report on the Echinoderms collected at Ceylan. Report Ceylon Pearl Oysters Fisheries. Part II. Supplementary Report.

Hume, W. Fr. 1906. The topography and geology of the peninsular of Sinai. Cairo Surv. Descript. Egypt.

Jackson, R. Tr. 1912. Phylogeny of the Echini. Mem. Boston Soc. Nat. Hist. Vol. VII.

Kœhler, R. 1895. Notes échinologiques. Revue biologique du Nord de la France. Vol. VII, Mémoire $\mathrm{n}^{\circ} 8$.

Kohler, R. 1905. Catalogue raisonné des Échinodermes recueillis par M. Korrotnef aux Iles de la Sonde. Mém. Soc. Zool. France. Vol. VIII.

Kœhler, R. 1922. Anomalies et irregularités du test des Échinides. Bull. Inst. Océanographique, $\mathrm{n}^{\circ}$ 414. Monaco, 1922.

Kœhler, R. 1924. Annomalies, Irregularités et Déformations du test chez les Échinides. Annal. Inst. Océanogr. Nouvelle série, t. I, Paris, 1924.

Kohler, R. and Bonnet, A. 1924. Documents pour server a l'étude de la variation chez les Echinides. I. Variations des auricules. Bull. Inst. Océanogr. n ${ }^{\circ} 446$.

Lamarck, J. B. 1816. Histoire naturelle des animaux sans vertébres. Ed. 2, Vol. III, Paris.

Lambert, J. and Thiéry, P. 1909-1925. Essai de nomenclature raisonée des Échinides. Chaumont.

Leske, N. G. 1788. Addimenta ad naturalem dispositionem Echinodermatum. Leipzig.

Linné, C. 1758. Systema naturæ.

Loriol, P. de. 1873. Description de trois espéces d'Échinides appartenant à la famille des Cidaridæ. Mém. Soc. Sc. Nat. Neuchâtel. T. V.

Loriol, P. de. 1883. Catalogue raisonné des Échinodermes recueillis par M. de Robillard à l'ile Maurice. Mém. Soc. Phys, Hist. Naturelle. Genève. T. XXVIII.

Loriol, P. de. 1893. Echinodermes de la baie d'Amboine. Revue Suisse de Zoologie. T. I.

Lovén, S. 1887. On the species of Echinoidea described by Linnæus. Kgl. Svenska Vet. Akad. Handl. Vol. XIII, $\mathrm{n}^{\circ}$ 5, Abth 4.

Lütke, Ch. 1864. Bidrag til Kundskab om Echiniderne. Vidensk. Meddel. Fra d. naturhist. Foren. Copenhague.

Mazetti, A. G. 1894. Gli Echinidi del Mar Rosso. Mem. Acad. Modence. T. X.

Meijere, J. C. H. de. 1903. Vorl. Reschr. der neuen, durch di "SIBOGA" Expedition, ges. Echiniden. Tijdsch. Nederland Dierk, Verein (2). Vol. VIII/.

Meijere, J. C. H de. 1904. Die Echinoidea der Siboga-Expediton. "SIBOGA” Expeditie, Monnogr. 48.

Michelin, H. 1862. Échinides et Stellérides. Notes sur l'ile de La Réunion, par L. Maillard.

Mortensen, Th. 1863. The Danish Ingolf-Expedition. Vol. IV. Echinoidea, part I. Copenhague.

Mortensen, Th. 1904. The Danish Expedition to Siam. Echinoidea. 
Mortensen, Th. 1910. On some Echinothurids from Japan and the Indian Ocean. Ann. Mag. Nat. Hist. (7). Vol. XIV.

Mortensen, Th. $1910 a$. The Echinoiden der deutschen Südpolar Expedition. Deutsche Südpolarl Expedition. Bd. IX.

Mortensen, Th. 1918. Results of Dr. Mjôbergs Swedish Scientific Expeditions to Australia. Kgl. Svenska Velenk. Akad. Handt. Bd. LVIII, nº 9.

Pallas, P. S. 1774. Spicilegia zoologica, I, fasc. X.

Peters, W. 1854. Ueber die an der Küste von Mossambique beobachteten Seeigel. Abh. K. Ak. Wissensch. Berlin, Physik. Kl. 1854.

Rudmose-Brown R. N. 1910. Echinoidea and Asteroidea from the Mergui Archipelago. Proc. Roy. Soc. Edinburgh. Vol. VIII, n ${ }^{\circ} 1$.

Rudmose-Brown, R. N. 1910 a. Echinoidea from the Kerimba Archipelago (Mossambique). $I b$.

Sarasin, G. F. and F. B. 1887. Die Augen und das Integument der Diadematiden. Ergebnisse naturw. Forschungen auf Ceylon. B. I.

Sluiter, Ph. 1895. Die Echiniden-Sammlung des Museums zu Amsterdam. Bijdr. Dierkunde Amsterdam. Afl. 17.

Stewart, Ch. 1880. On some structural features of Echinostrephus molare and Stomopneustes variolaris. Journ. R. Micr. Soc., Vol. III, ${ }^{\circ} 6$.

Verrill, A. E. 1867. Notes on Radiata. Trans. Connecticut Acad. Vol. I.

Tokunaga, S. Fossils from the environs of Tokyo. Tokio Journ. Coll. Sc. T. XXI, 1906; art. 2.

Wood-Mason, J., and Alcock, A. 1891. Natural History Notes from steamer "INVESTIGATOR". Series 2, n 1, Ann. Mag. Nat. History. (6), Vol. 8.

Woods, J. E. T. 1883. On a new species of Stomopneustes. Proc. Linnean Soc. South Wales. Vol. VII. 


\section{EXPLANATION OF THE PLATES}

\section{PLATE I}

Fig. 1. Histocidaris denticulata; dried specimen (A); ventral surface. Mag. 1.6.

Fig. 2. Histocidaris denticulata; specimen in alcohol (B); ventral surface. Natural size.

Fig. 3. Histocidaris denticulata; specimen A; dorsal surface. Mag. 1.6.

Fig. 4. Dorocidaris tiara; dorsal surface. Mag. 2.

Fig. 5. Dorocidaris tiara; enlarged portion of an ambulacrum. Mag.5.4.

Fig. 6. Histocidaris denticulata; enlarged portion of an ambulacrum. Mag. 7.

Fig. 7. Histocidaris denticulata; enlarged portion of the ventral surface of specimen A, Mag. 5.

\section{PLATE II}

Fig. 1. Histocidaris denticulata; large spines of specimen A. Mag. 3.2.

Fig. 2. Dorocidaris tiara; ventral surface. Mag. 2.4.

Fig. 3. Stereocidaris indica; specimen with spines removed; dorsal surface. Mag. 1.3.

Fig. 4. Stereocidaris indica; dorsal surface. Mag. 1.4.

Fig. 5. Stereocidaris indica; specimen with spines removed whose dorsal surface is represented in fig. 3; lateral view by an interradius. Mag. 1.3.

Fig. 6. Stereocidaris indica; same specimen; lateral view by a radius. Mag. 1.3.

Fig. 7. Stereocidaris indica; lateral view of the specimen represented in fig. 6 and with its spines. Mag. 1.4.

\section{PLATE III}

Fig. 1. Dorocidaris tiara; specimen with spines removed in part; ventral surface. Mag. 2.5.

Fig. 2. Dorocidaris Lorioli; dorsal surface. Mag. 2.

Fig. 3. Dorocidaris Lorioli; Another specimen; dorsal surface. Mag. 2.

Fig. 4. Dorocidaris Lorioli; isolated spines. Mag. 4.

Fig. 5. Dorocidaris Lorioli; lateral view. Mag. 2.

Fig. 6. Dorocidaris tiara; spines in transition to those of D. Lorioli. Mag. 3.

\section{PLATE IV}

Fig. 1. Dorocidaris tiara; specimen with its spines; ventral surface. Mag. 2.

Fig. 2. Dorocidaris tiara; another specimen with its spines, ventral surface. Mag. 2.

Fig. 3. Stereocidaris indica; isolated spines. Mag. 3.

Fig. 4. Dorocidaris tiara; specimen with spines removed with test very elevated; lateral view by an interradius. Mag. 1.5.

Fig. 5. Dorocidaris tiara; same specimen; lateral view by a radius. Mag. 1.5.

Fig. 6. Dorocidaris tiara; specimen represented in Fig. 2 seen by the dorsal surface. Mag. 2.

Fig. 7. Dorocidaris tiara; specimen with spines removed with rather low test; lateral view by an interradius. Mag. 2.4.

Fig. 8. Dorocidaris tiara; similar specimen seen by a radius. Mag. 2.4.

Fig. 9. Dorocidaris tiara; specimen with test more elevated, seen by a radius. Mag. 2. 
Fig. 10. Stereocidaris indica; specimen with spines partially removed; lateral view by a radius. Mag. 1.3.

\section{PLATE V}

Fig. 1. Prionocidaris brevicollis; specimen without locality; ventral surface. Mag. 1.8.

Fig. 2. Acanthocidaris maculicollis; specimen with two parasitic prosobranchs; oblique view from the ventral surface. Mag. 2.3.

Fig. 3. Acanthocidaris maculicollis; another specimen, ventral surface. Mag. 1.9.

Fig. 4. Prionocidaris brevicollis; isolated spines. Mag. 3.2.

Fig. 5. Prionocidaris brevicollis; specimen from Interview Island; lateral view. Mag. 1.8.

Fig. 6. Prionocidaris brevicollis; another specimen from the same location; ventral surface. Mag. 2.2.

\section{PLATE VI}

Fig. 1. Doriocidaris tiara; dorsal surface. Mag. 1.5.

Fig. 2. Stereocidaris Alcocki; specimen with spines removed in part; dorsal surface. Mag. 1.3.

Fig. 3. Stereocidaris Alcocki; specimen with spines removed; dorsal surface. Mag. 1.4.

Fig. 4. Stereocidaris Alcocki; same specimen; lateral view by a radius. Mag. 1.4.

Fig. 5. Dorocidaris tiara; specimen with spines removed; lateral view by an interradius. Mag. 2.

Fig. 6. Dorocidaris tiara; isolated spines. Mag. 3.

Fig. 7. Stereocidaris Alcocki; dorsal surface. Mag. 1.3.

Fig. 8. Stereocidaris Alcocki; specimen with spines removed represented in fig. 3 and 4; ventral surface. Mag. 1.4.

Fig. 9. Stereocidaris Alcocki; same specimen; lateral view by an interradius. Mag. 1.4.

\section{PLATE VII}

Fig. 1. Phormosoma indicum; specimen with spines partially removed; dorsal surface. Mag. 1.3.

Fig. 2. Phormosoma indicum; another specimen; apical system. Mag. 1.8.

Fig. 3. Phormosoma verticillatum; dorsal surface. Mag. 1.3.

Fig. 4. Phormosoma indicum; apical system; enlarged from the specimen represented in fig. 1. Mag. 2.

Fig. 5. Arceosoma coriaceum var. indicum; dorsal surface; slightly reduced.

Fig. 6. Phormosoma indicum; dorsal surface. Mag. 1.8.

\section{PLATE VIII}

Fig. 1. Sperosoma armatum; dorsal surface; slightly reduced.

Fig. 2. Phormosoma indicum; dorsal surface. Mag. 2.5.

Fig. 3. Arceosoma coriaceum var. indicum; apical system. Mag. 2.

Fig. 4. Chœtodiadema granulatum; specimen measuring $20 \mathrm{~mm}$ in diameter; apical system. Mag. 4.2.

Fig. 5. Chotodiadema granulatum; specimen measuring $17 \mathrm{~mm}$. Mag. 5.3.

Fig. 6. Sperosoma armatum; ventral surface; slightly reduced.

\section{PLATE IX}

Fig. 1. Chotodiadema granulatum; specimen whose diameter is $33 \mathrm{~mm}$; apical system. Mag. 3.8.

Fig. 2. Chotodiadema granulatum; specimen whose diameter is $73 \mathrm{~mm}$; apical system. Mag. 2.6.

Fig. 3. Chœtodiadema granulatum; entire specimen; dorsal surface. Natural size.

Fig. 4. Centrostephanus nitidus; specimen measuring $18 \mathrm{~mm}$ in diameter; dorsal surface. Mag. 2.5.

Fig. 5. Centrostephanus nitidus; specimen A; lateral view. Mag. 1.6.

Fig. 6. Centrostephanus nitidus; specimen B; lateral view. Mag. 1.6.

Fig. 7. Centrostephanus nitidus; specimen F; dorsal surface. Mag. 2.5. 
Fig. 8. Centrostephanus nitidus; specimen G; dorsal surface. Mag. 2.5.

Fig. 9. Centrostephanus nitidus; specimen D with its spines removed; dorsal surface. Mag. 2.5.

Fig. 10. Centrostephanus nitidus; specimen F; ventral surface. Mag. 4.

\section{PLATE X}

Fig. 1. Centrostephanus nitidus; small specimen C; lateral view. Mag. 2.

Fig. 2. Coelopleurus vittatus; dorsal surface. Mag. 2.

Fig. 3. Centrostephanus nitidus; specimen E; apical system. Mag. 4.5.

Fig. 4. Centrostephanus nitidus; specimen D; apical system. Mag. 4.5.

Fig. 5. Coelopleurus vittatus; lateral view. Mag. 1.5.

Fig. 6. Celopleurus vittatus; another lateral view. Mag. 1.5.

Fig. 7. Colopleurus vittatus; ventral surface. Mag. 1.5.

Fig. 8. Centrostephanus nitidus; specimen E with part of spines removed; dorsal surface. Mag. 2.

Fig. 9. Centrostephanus nitidus; specimen F; apical system. Mag. 5.

Fig. 10. Colopleurus vittatus; three isolated spines. Mag. 4.

\section{PLATE XI}

Fig. 1 to 6, Aspidodiadema annulatum.

Fig. 1 and 2. Lateral view of two large specimens. Mag. 4.

Fig. 3. Ventral surface. Mag. 3.

Fig. 4. Ventral surface of the same specimen more enlarged. Mag. 4.

Fig. 5. Ventral surface of another specimen. Mag. 4.5.

Fig. 6. Dorsal surface. Mag. 4.5.

Fig. 7 to 9, Pygmacocidaris prionigera.

Fig. 7. Lateral view. Mag. 5.

Fig. 8. Dorsal surface. Mag. 5.

Fig. 9. Dorsal surface more enlarged. Mag. 10.

Fig. 10 to 13. Salenia sculpta.

Fig. 10. Lateral view of an entire specimen.

Fig. 11. Ventral surface of a specimen with its spines removed. Mag. 9.

Fig. 12. Dorsal surface of another specimen with its spines removed. Mag. 7.

Fig. 13. Oblique lateral view of an entire specimen. Mag.4.

\section{PLATE XII}

Fig. 1. Salenia sculpta; specimen with its spines removed; dorsal surface. Mag. 9.

Fig. 2. Salenia sculpta; specimen with its spines removed whose ventral surface is represented in Pl. XI, fig. 11; dorsal surface. Mag. 8.

Fig. 3. Salmacis roseo-viridis; enlarged portion of the test. Mag. 5.

Fig. 4. Salmacis roseo-viridis: small specimen (B); lateral view. Mag. 1.8.

Fig. 5. Salmacis roseo-viridis; large specimen (A) with spines removed in part; dorsal view. Mag. 1.4.

Fig. 6. Salmacis roseo-viridis; large specimen with spines removed in part; lateral view. Mag. 1.4.

Fig. 7. Conopedina depressa; lateral view. Mag. 4.5.

Fig. 8. Conopedina depressa; dorsal surface. Mag. 4.2.

Fig. 9. Conopedina depressa; ventral surface. Mag. 4.2.

Fig. 10. Salenia sculpta; specimen with its spines removed. Mag. 7.

Fig. 11. Salmacis Dussumieri; specimen with part of its spines removed; dorsal surface. Mag. 2. 


\section{PLATE XIII}

Fig. 1 to 4. Salmacis bicolor.

Fig. 1. Specimen B; portion of an interambulacral zone. Mag. 3.8.

Fig. 2. Specimen D; portion of an interambulacral zone. Mag. 3.8.

Fig. 3. Specimen D; portion of an ambulacral zone. Mag. 3.8.

Fig. 4. Specimen C; portion of an interambulacral zone. Mag. 3.8.

Fig. 5. Salmacis Dussumieri; portion of an ambulacral zone. Mag. 3.8.

Fig. 6 to 11. Salmacis bicolor.

Fig. 6. Specimen A; portion of ambulacral zone I. Mag. 3.8.

Fig. 7. Specimen A; portion of ambulacral zone II. Mag. 3.8.

Fig. 8. Specimen A; portion of interambulacral zone 2. Mag. 3.8.

Fig. 9. Specimen A; portion of interambulacral zone 3. Mag. 3.8.

Fig. 10. Specimen A; portion of interambulacral zone 5. Mag. 3.8.

Fig. 11. Specimen A; portion of ambulacral zone IV. Mag. 3.8.

Fig. 12. Salmacis rarispina; portion of an interambulacral zone. Mag. 4.

Fig. 13. Salmacis rarispina; portion of an ambulacral zone. Mag. 4.

Fig. 14 to 17. Apical system of various Temnopleurus toreumaticus.

Fig. 14. Specimen measuring $8 \mathrm{~mm}$ in diameter. Mag. 10.

Fig. 15. Specimen measuring $10 \mathrm{~mm}$ in diameter. Mag. 10.

Fig. 16. Specimen measuring $15 \mathrm{~mm}$ in diameter. Mag. 10 .

Fig. 17. Specimen measuring $21 \mathrm{~mm}$ in diameter. Mag. 10,

\section{PLATE XIV}

Fig. 1. Temnopleurus toreumaticus; specimen with part of spines removed; dorsal surface. Mag. 2.

Fig. 2. Temnopleurus toreumaticus; lateral view of the same. Mag. 2.

Fig. 3. Trigonocidaris versicolor; dorsal surface. Mag. 8.

Fig. 4. Trigonocidaris versicolor; another specimen with a part of the spines removed; dorsal surface. Mag. 7.

Fig. 5. Trigonocidaris albida; dorsal surface. Mag. 7.

Fig. 6. Trigonocidaris versicolor; apical system. Mag. 13.

Fig. 7. Trigonocidaris versicolor; ventral surface. Mag. 7.

Fig. 8. Trigonocidaris versicolor; ventral surface of another specimen. Mag. 7.

Fig. 9. Trigonocidaris versicolor; dorsal surface. Mag. 6.5.

Fig. 10. Trigonocidaris versicolor; apical system. Mag. 12.

Fig. 11. Temnotrema siamense; dorsal surface. Mag. 8.

Fig. 12. Temnotrema scilla; dorsal surface. Mag. 8.

Fig. 13. Trigonocidaris versicolor; apical system. Mag. 12.

Fig. 14. Temnotrema siamense; dorsal surface of a specimen whose periproct is covered by a single round, large plate. Mag. 8 .

\section{PLATE XV}

Fig. 1. Prionechinus Agassizii; dorsal surface. Mag. 5.

Fig. 2. Prionechinus Agassizii; lateral view. Mag. 5.

Fig. 3 to 11. Printechinus impressus.

Fig. 3. Auricle. Mag. 5.5.

Fig. 4. Specimen from which its spines have been removed; dorsal surface. Mag. 2.8.

Fig. 5. Same specimen; later view from an interambulacral zone. Mag. 2.7.

Fig. 6. Apical system. Mag. 5.7.

Fig. 7. Ventral surface of a specimen from which its spines have been removed. Mag. 2.7.

Fig. 8. Ventral surface of a specimen with its spines. Mag. 2.9.

Fig. 9. Enlarged portion of an interambulacral zone. Mag. 5.2. 
Fig. 10. Enlarged portion of an ambulacral zone. Mag. 5.2.

Fig. 11. Specimen represented in fig. 4 and 5; lateral view from a radius. Mag. 2.8.

\section{PLATE XVI}

Fig. 1 to 4. Echinometra Mathoei.

Fig. 1. Specimen from Madagascar; dorsal surface. Mag. 1.4.

Fig. 2. Same specimen; lateral view. Mag. 1.4.

Fig. 3. Specimen from the Bay of Bengal; dorsal surface. Mag. 1.4.

Fig. 4. Same specimen; lateral view. Mag. 1.4.

Fig. 5 to 15. Echinometra Michelini.

Fig. 5. Specimen B; dorsal surface. Mag. 2.

Fig. 6. Specimen D; dorsal surface. Mag. 2.

Fig. 7. Specimen E; dorsal surface. Mag. 2.

Fig. 8. Specimen G; lateral view. Mag. 2.

Fig. 9. Specimen B; lateral view. Mag. 2.

Fig. 10. Specimen G; auricle I. Mag. 1.5.

Fig. 11. Specimen G; auricle II. Mag. 1.5.

Fig. 12. Specimen G; auricle III. Mag. 1.5.

Fig. 13. Specimen G; auricle IV. Mag. 1.5.

Fig. 14. Specimen G; auricle V. Mag. 1.5.

Fig. 15. Specimen F; auricle III. Mag. 1.5.

\section{PLATE XVII}

Fig.1 to 4. Echinometra Michelini.

Fig. 1. Specimen G; dorsal surface. Mag. 2.

Fig. 2. Specimen G, dorsal surface. Mag. 2.

Fig. 3. Specimen F; dorsal surface. Mag. 2.

Fig. 4. Specimen C; lateral view. Mag. 2.

Fig. 5. Gymnechinus pallidus; apical apparatus of specimen $\mathrm{C}$ in which the plates of the periproct are unequal. Mag. 6.

Fig. 6 to 10. Echinometra Mathai, specimen A.

Fig. 6. Auricle I. Mag. 1.5.

Fig. 7. Auricle II. Mag. 1.5.

Fig. 8. Auricle III. Mag. 1.5.

Fig. 9. Auricle IV. Mag. 1.5.

Fig. 10. Auricle V. Mag. 1.5.

Fig. 11. Prymnechinus proctalis; specimen A; portion of the dorsal surface. Mag. 9.

Fig. 12. Same specimen, less enlarged; dorsal surface. Mag. 5.

Fig. 13. Gymnechinus pallidus; specimen D; apical system. Mag. 7.

Fig. 14. Prymnechinus proctalis; specimen B; dorsal surface. Mag. 9.

Fig. 15. Gymnechinus pallidus; specimen $\mathrm{F}$ in which the periproctal plates are less numerous; dorsal surface. Mag. 5.

Fig. 16. Gymnechinus megaloplax; portion of the dorsal surface. Mag. 9.

Fig. 17 to 19. Echinometra Michelini.

Fig. 17. Specimen C; auricle V. Mag. 1.5.

Fig. 18. Specimen D; auricle I. Mag. 1.5.

Fig. 19. Specimen B; auricle I. Mag. 1.5.

\section{PLATE XVIII}

Fig. 1 to 6. Gymnechinus pallidus.

Fig. 1. Specimen B from which part of the spines have been removed; dorsal surface. Mag. 4. 
Fig. 2. Specimen $C$ from which part of the spines have been removed; dorsal surface. Mag. 3.

Fig. 3. Specimen B; ventral surface. Mag. 4.

Fig. 4. Specimen B; apical system. Mag. 6.

Fig. 5. Specimen A; apical system. Mag. 5.

Fig. 6. Specimen B; lateral view. Mag. 4.

Fig. 7 and 8. Lytechinus Thiery.

Fig. 7. Apical system. Mag. 4.5.

Fig. 8. Dorsal surface. Mag. 3.

Fig. 9. Echinostrephus molaris; dorsal surface. Mag. 4.5.

\section{PLATE XIX}

Fig. 1. Lytechinus Theiry; lateral view. Mag. 3.

Fig. 2. Gymnechinus pallidus; specimen A; abnormal ambulacral zone. Mag. 9.

Fig. 3. Gymnechinus pallidus Specimen E; apical system. Mag. 6.

Fig. 4. Lytechinus Theiry; portion of the ventral surface. Mag. 6.

Fig. 5 to 10. Stereocidaris indica; abnormal specimen A.

Fig. 5. Dorsal surface. Mag. 1.5.

Fig. 6. Enlarged portion of radius I. Mag. 4.

Fig. 7. Lateral view by interradius 2. Mag. 1.5.

Fig. 8. Lateral view by interradius 5. Mag. 1.5.

Fig. 9. Lateral view by radius I. Mag. 1.5.

Fig. 10, Lateral view by radius V. Mag. 1.5.

Fig. 11. Abnormal Stereocidaris indica; specimen B; enlarged part of radius I. Mag. 5.

\section{PLATE XX}

Fig. 1 to 4. Abnormal Stereocidaris indica; specimen B; lateral view.

Fig. 1. Lateral view by radius I and V and interradius 5. Mag. 1.5.

Fig. 2. Lateral view by radius I. Mag. 1.5.

Fig. 3. Dorsal surface. Mag. 1.5.

Fig. 4. Lateral view by radius V. Mag. 1.5.

Fig. 5 to 8. Abnormal Stereocidaris indica; specimen C.

Fig. 5. Enlarged portion of radius IV. Mag. 5.

Fig. 6. Lateral view of test by radius IV. Mag. 1.5.

Fig. 7. Dorsal surface. Mag. 1.5

Fig. 8. Enlarged portion of radius IV seen a little obliquely. Mag. 4.

Fig. 9. The two parasitic Mucronalia of Stereocidaris indica D. Mag. 6.

\section{PLATE XXI}

Fig. 1 to 4. Abnormal Stereocidaris indica; specimen D.

Fig. 1. Dorsal surface G. Mag. 1.6.

Fig. 2. Lateral view by radius III. Mag. 1.6.

Fig. 3. Enlarged portion or radius III. Mag. 4.5.

Fig. 4. Lateral view of test with spines and showing the parasitic Mucronalia in place. Mag. 1.7.

Fig. 5. Abnormal Stereocidaris indica; specimen E; lateral view by radius II with the two parasitic Mucronalia. Mag. 1.6.

Fig. 6. Specimen D; lateral view by radius IV. Mag. 1.6.

Fig. 7. Specimen E; dorsal surface. Mag. 1.7.

Fig. 8, 9 and 11. Spines of Dorocidaris tiara modified by the presence of parasitic Megadenus. Mag. 9.

Fig. 10. The two parasitic Mucronalia of Stereocidaris indica E. Mag. 9. 


\section{PLATE XXII}

Fig. 1 to 4. Dorocidaris tiara; specimens of which some spines have been modified by the presence of parasitic Megadenus. Mag. 2.2.

Fig. 5 to 16. Dorocidaris tiara; spines modified by Megadenus, isolated and very enlarged. Mag. 9.

\section{PLATE XXIII}

Fig. 1. Histocidaris denticulata; tridactyle pedicellariae; a, valves of the large pedicellariae, Mag. 14; b, small pedicellariae. Mag. 57.

Fig. 2. Dorocidaris tiara; a, valves of the large tridactyles enlarged, the first 14 times and the second 8 times; b, small tridactyles of different sizes, Mag. 48; c, large and small globiferous, Mag. 105.

Fig. 3. Prionocidaris brevicollis; a, valves of large globiferous pedicellariae of the second kind, Mag. 105; b, large globiferous of the first kind Mag. 180; c, tridactyles, Mag. 105; d, globiferous of the third kind Mag. 105.

Fig. 4. Acanthocidaris maculicollis; a, tridactyle pedicellariae of the large form, Mag. 40; b, globiferous pedicellariae of the large form; Mag. 55; c, small form of globiferous, Mag. 70; d, small tridactyle, Mag. 105.

Fig. 5. Stereocidaris indica; valves of globiferous. Mag. 105.

Fig. 6. Stereocidaris Alcocki; a, valves of globiferous; b, valves of tridactyles.

\section{PLATE XXIV}

Fig. 1. Hygrosoma luculentum; a, valves of large tridactyle pedicellariae, Mag. 48; b, valves of small tridactyles of different forms, Mag. 48.

Fig. 2. Phormosoma verticillatum; a, valves of small tridactles with a particular form, Mag. 60; b, valves of tridactyles with a cylindrical head, Mag. 48; c, valve of ophiocephalous, Mag. 70; d, sphaeridia, Mag. 75.

Fig. 3. Arceosoma coriaceum var. indicum; a, valves of very large tridactyle pedicellariae with a conical head, Mag. 48; b, large tridactyle pedicellariae with narrow and elongated valves, Mag 48; c, small tridactyle pedicellariae with an elongated head, Mag. 75; d, small tridactyles with a conical head, Mag. 50; c, trifoliate, Mag. 100.

\section{PLATE XXV}

Fig. 1. Phormosoma indicum; a, large tridactyle pedicellariae with a narrow and elongated head, Mag. 48; b, small tridactyle pedicellariae with a narrow and elongated head, Mag. 75; c, tridactyle with an enlarged head, Mag. 48.

Fig. 2. Sperosoma biseriatum; a, large tridactyle pedicellariae with very wide valves, Mag. 48; b, small tridactyle pedicellariae with narrow valves, Mag. 48.

Fig. 3. Sperosoma armatum; a, valves of very large tridactyle pedicellariae with a round head (first form), Mag. 20; b, smaller tridactyles with a slightly elongated head (second form), Mag. 48; c, small tridactyles of the third form, Mag. 60; d, ophiocephalous valve, Ma. 65.

Fig. 4. Chœetodiadema granulatum; terminal part of small spines of the ventral surface, Mag. 15.

Fig. 5. Salenia sculpta; heads of ophiocephalous pedicellariae, Mag. 190; b, ophiocephalous pedicellaria with its peduncle, Mag. 180; c, secondary spines, Mag. 30.

Fig. 6. Cœlopleurus vittatus; a, valves of tridactyles of the second form seen by the internal surface, Mag. 28; b, small tridactyles of the third form, Mag. 100; c, ophiocephalous of the buccal membrane, Mag. 58; d, ophiocephalous of the test, Mag. 58. 


\section{PLATE XXVI}

Fig. 1. Colopleurus vittatus; a, valves of the large tridactyles of the first form, Mag. 60; b, large tridactyle of the first form with a particularly shortened head, Mag. 60; c, tridacatyle pedicellariae of the fourth form, Mag. 105.

Fig. 2. Centrostephanus nitidus; a, perforated plates of the tube feet, Mag. 110; b, various spicules of the tube feet, Mag. 110; c, very large tridactyles of the first form, Mag. 65; d, ophiocephalous, Mag. 100; e, tridactyls with enlarged valves of the second form, Mag. 55; $\mathrm{f}$, portion of the primary spines, Mag. 105; g, end of the valve of a tridactyle of the third form, Mag. 100; h, valves of globiferous, Mag. 100; i, valves of trifoliate, Mag. 180; j, entire pedicellaria of the third form (rostrate), Mag. 60.

Fig. 3. Salmacis roseo-viridis; a, tridactyle pedicellariae of the second form, Mag. 100; b, large globiferous, Mag. 100; c, small globiferous, Mag. 200; d, valves of tridactyles of the first form, Mag. 55.

\section{PLATE XXVII}

Fig. 1. Trigonocidaris versicolor; a, valves of globiferous, Mag. 105; b, tridactyles, Mag. 105; c, ophiocephalous, Mag. 105.

Fig. 2. Printechinus impressus; a, valves of globiferous, Mag. 180; b, valves of trifoliate, Mag. 180; c, valves of tridactyles, Mag. 100; d. valve of ophiocephalous, Mag. 100.

Fig. 3. Stomopneustes variolaris; spicules of tube feet; a, fenestrated plates, Mag. 105; b, triradiate spicules, Mag. 180; c, spicules in the form of a biscuit, Mag. 105.

Fig. 4. Gymnechinus pallidus; a, globiferous, Mag. 180; b, ophiocephalous, Mag. 105; c, tridactyles, Mag. 105.

Fig. 5. Echinostrephus molaris; a, ophiocephalous, Mag. 105; b, tridactyle, Mag. 55; c, globiferous, Mag. 105.

Fig. 6. Lytechinus Thiery; a, valves of trifoliate, Mag. 180; b, large tridactyles, Mag. 180; c, small tridacatyle, Mag. 200; d, ophiocephalous, Mag. 105; e, globiferous, Mag. 105. 


\section{Plate I}

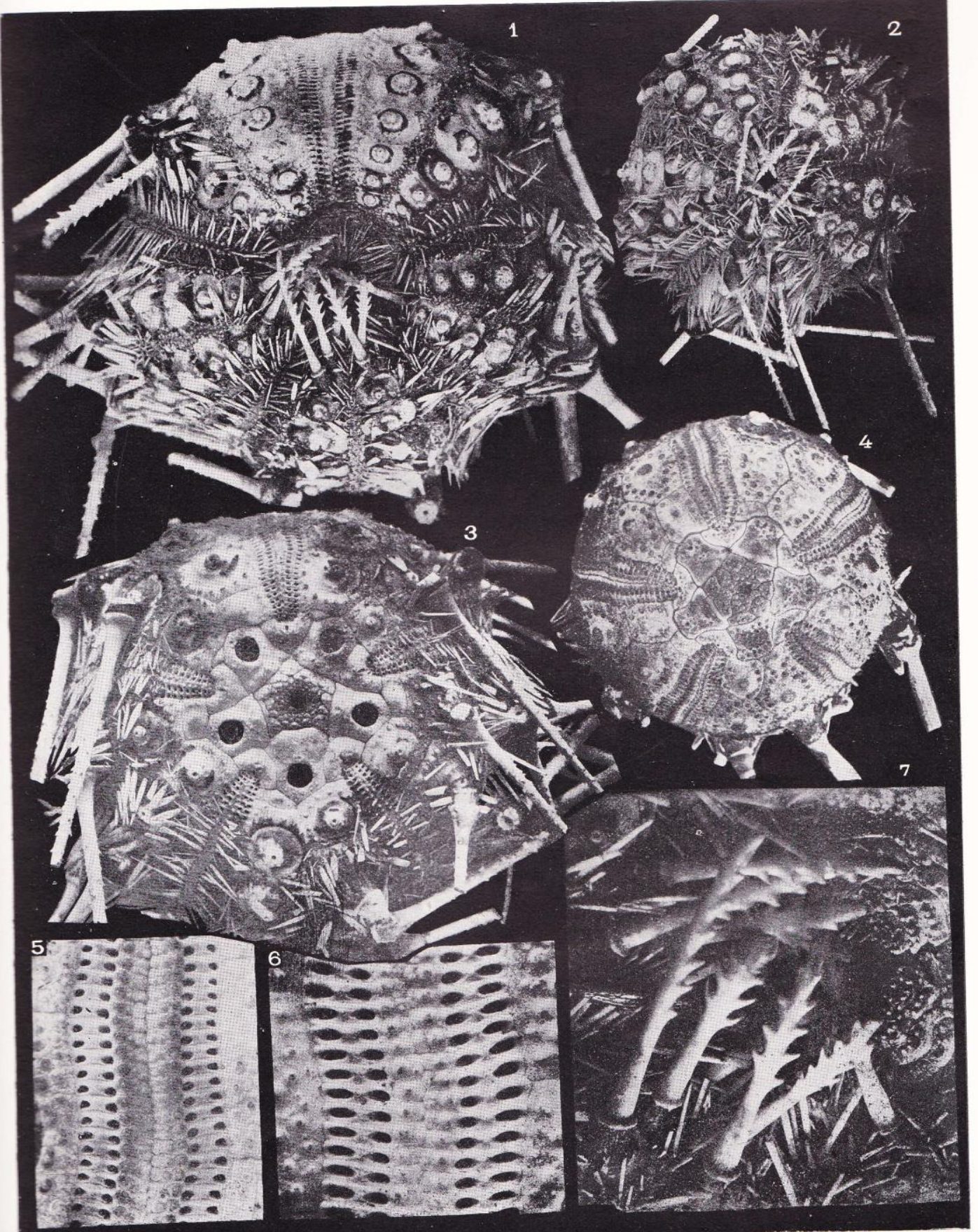

IR. Kiphler phot.

St: Lyonnaise de Photochromogravure 
Plate II

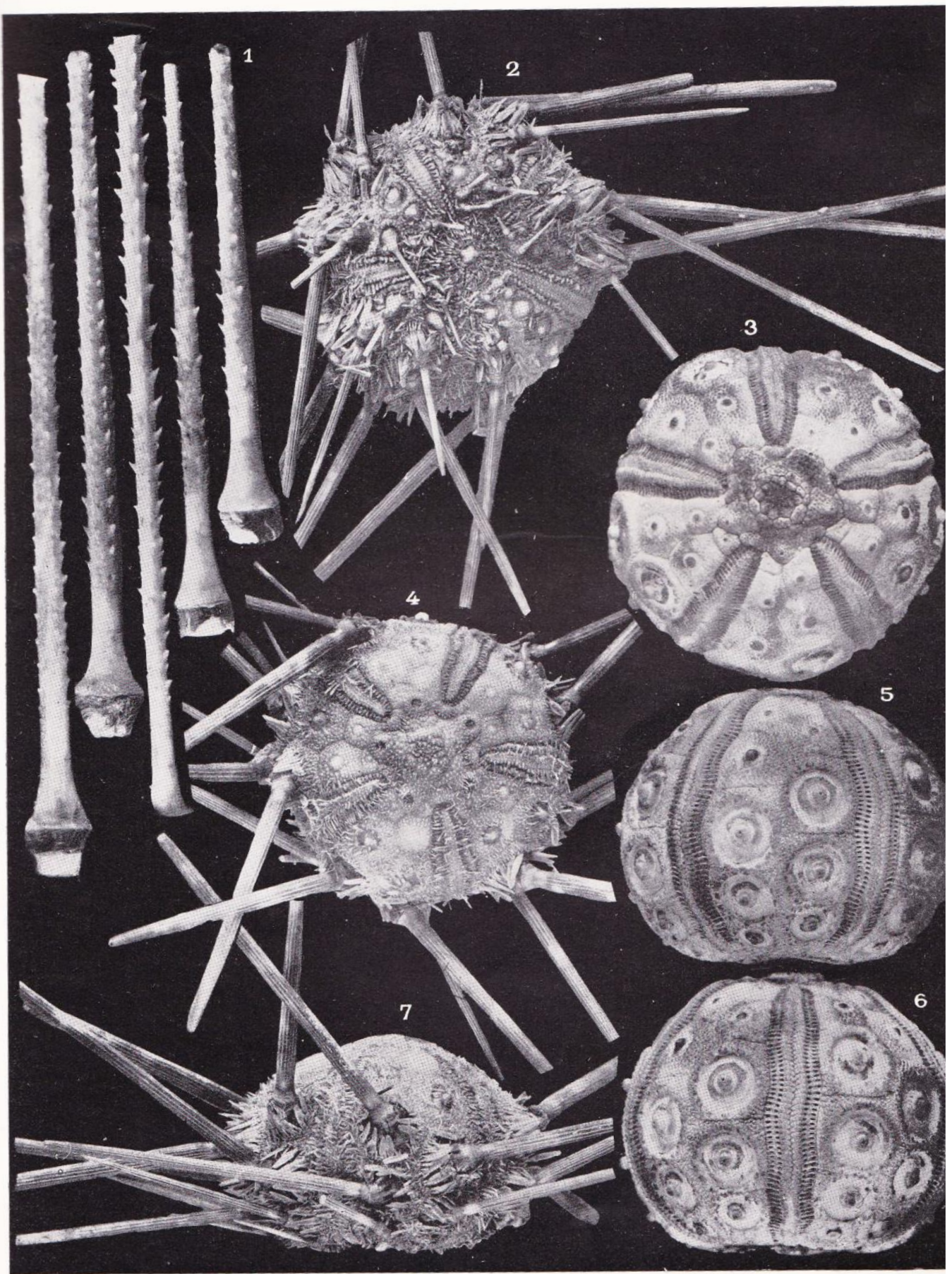

1:. Kohler phot.

Sté Lyonnaise de Photochromogravar

1 HISTOCIDARIS DENTICULATA. 2 LOROCIDARIS TIARA. 3-7 STEREOCIDARIS INDICA. 
Plate III

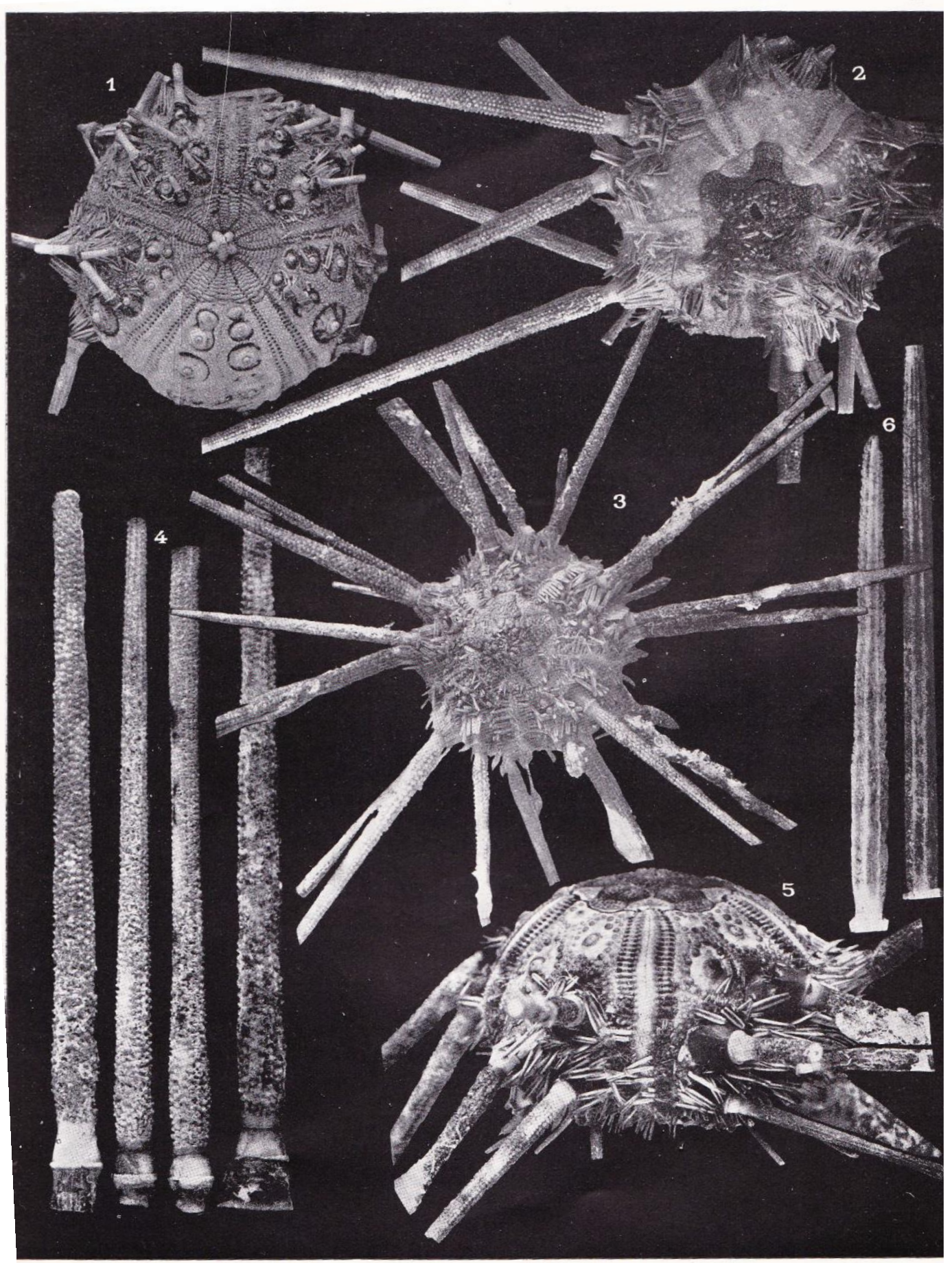

I. Kehler phot.

Sté Ivomnaise de Photochromogravure

1 et 6 DOROCIDARIS TIARA. 2-5 DOROCIDARIS LORIOLI. 


\section{Plate IV}

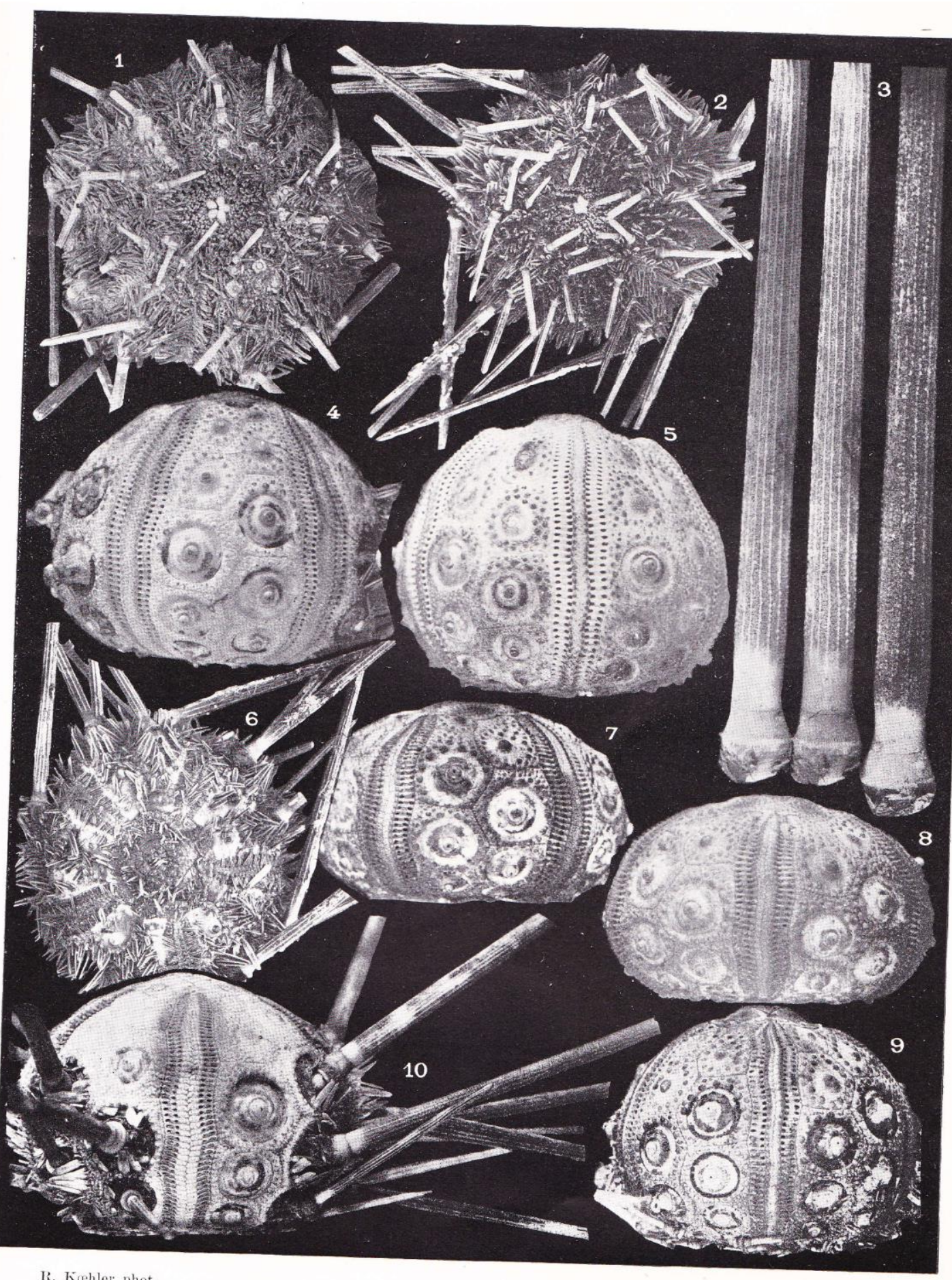

R. Kohler phot 


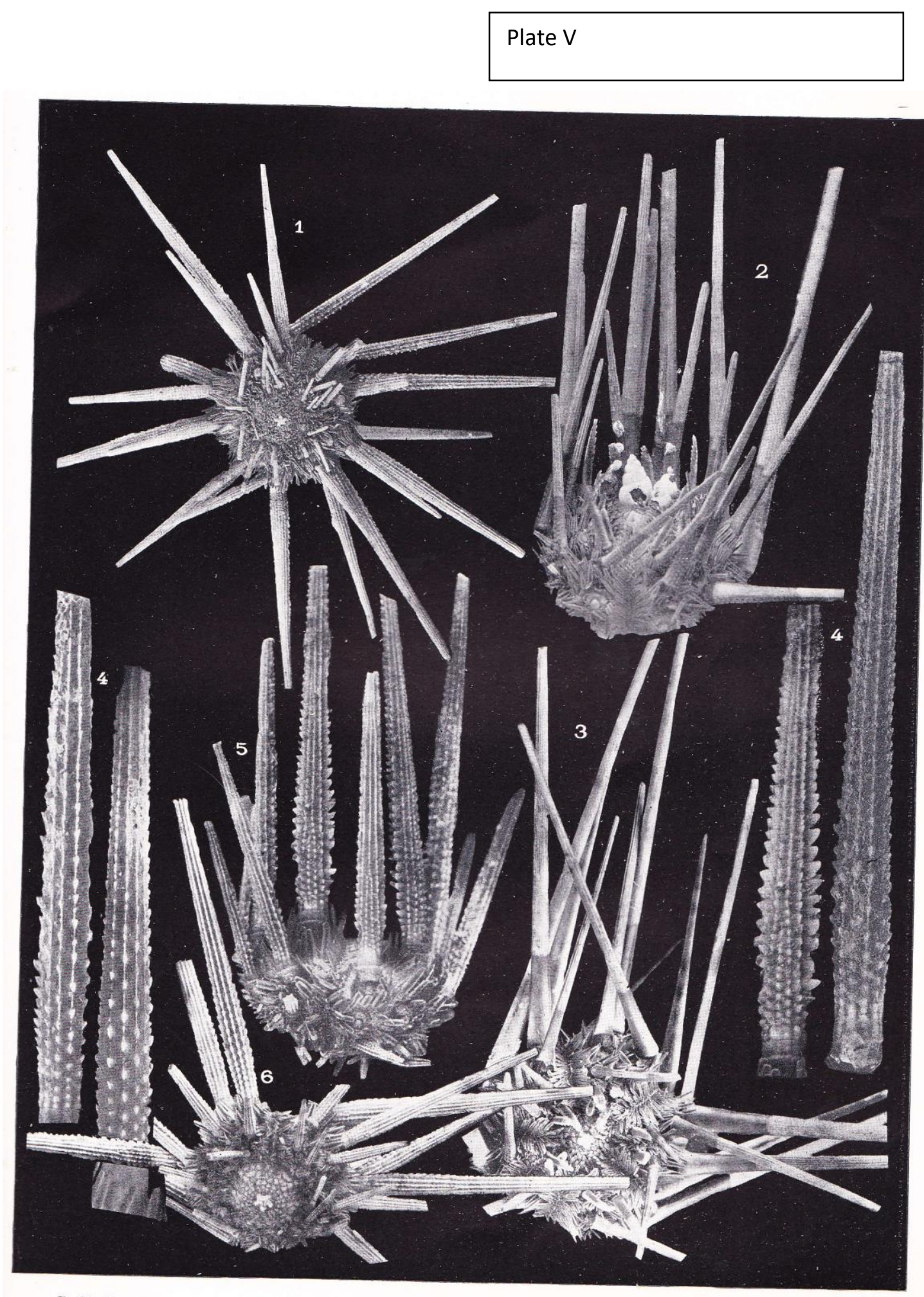

R. Kœhler phot.

Sté Lyonnaise de Photochromogravure

1 et 4-6 PRIONOCIDARIS BREVICOLLIS. 2 et 3 ACANTHOCIDARIS MACLLICOLLIS. 
Plate VI

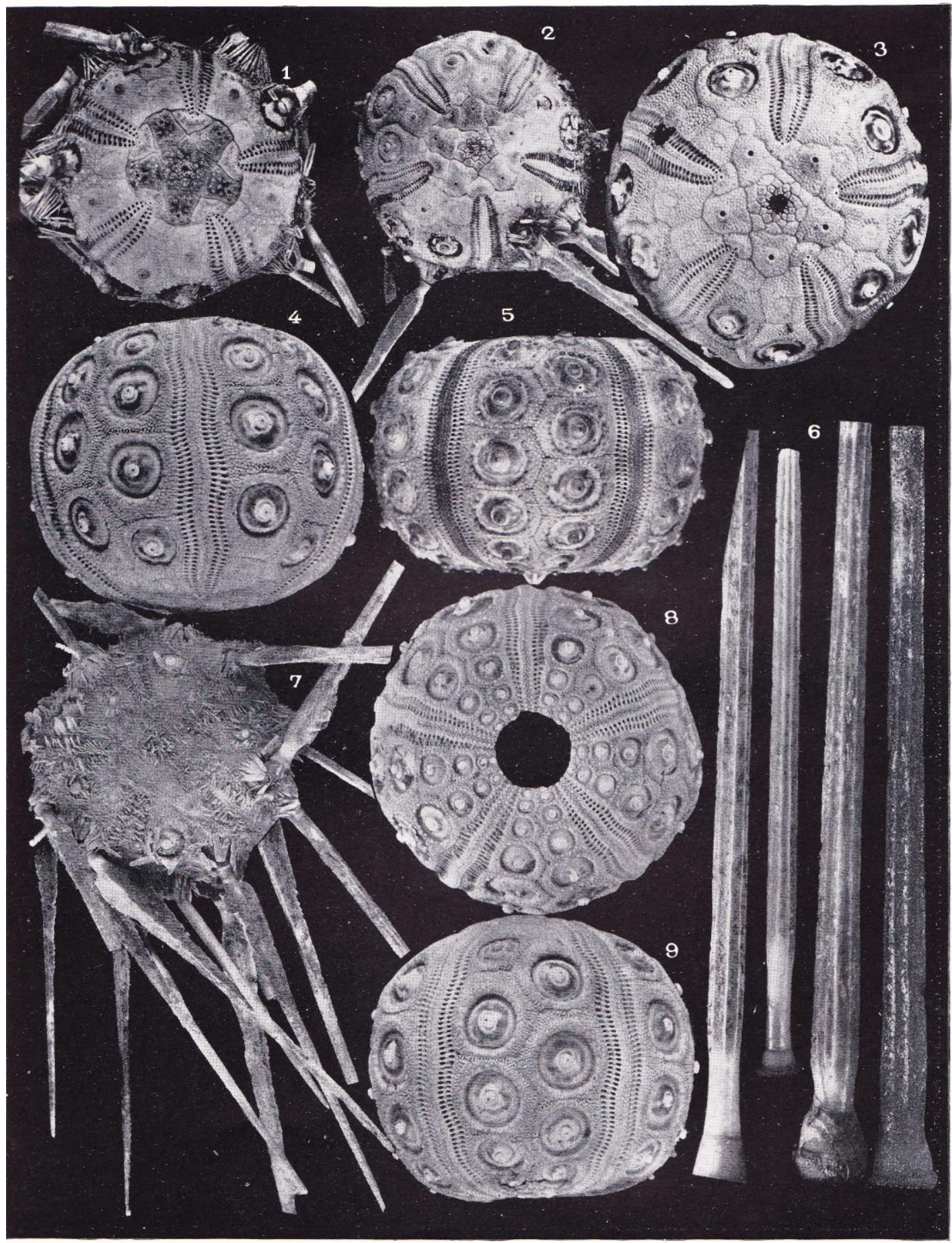

R. Kiphler phot.

Stẻ Ixonnaise de Photochromogravure 
Plate VII

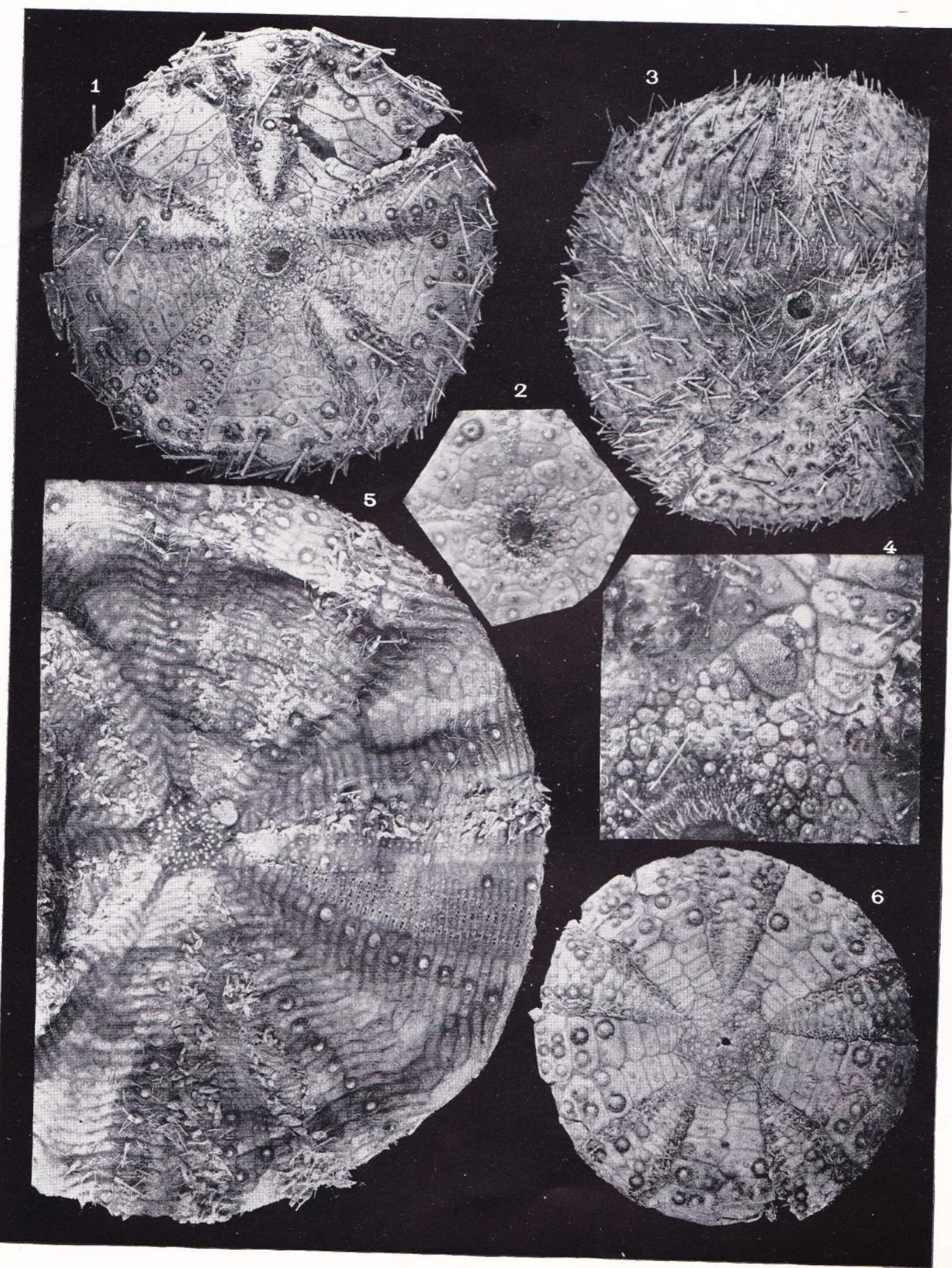

Ii. Kohler phot.

Sté Lyounaise de Photochromogravure

1-2, 4 et 6 PHORMOSOMA INDICUM. 3 PHORMOSOMA VERTICILLATLM.

5 AREOSOMA CORIACEUM Var. INIICUM. 


\section{Plate VIII}

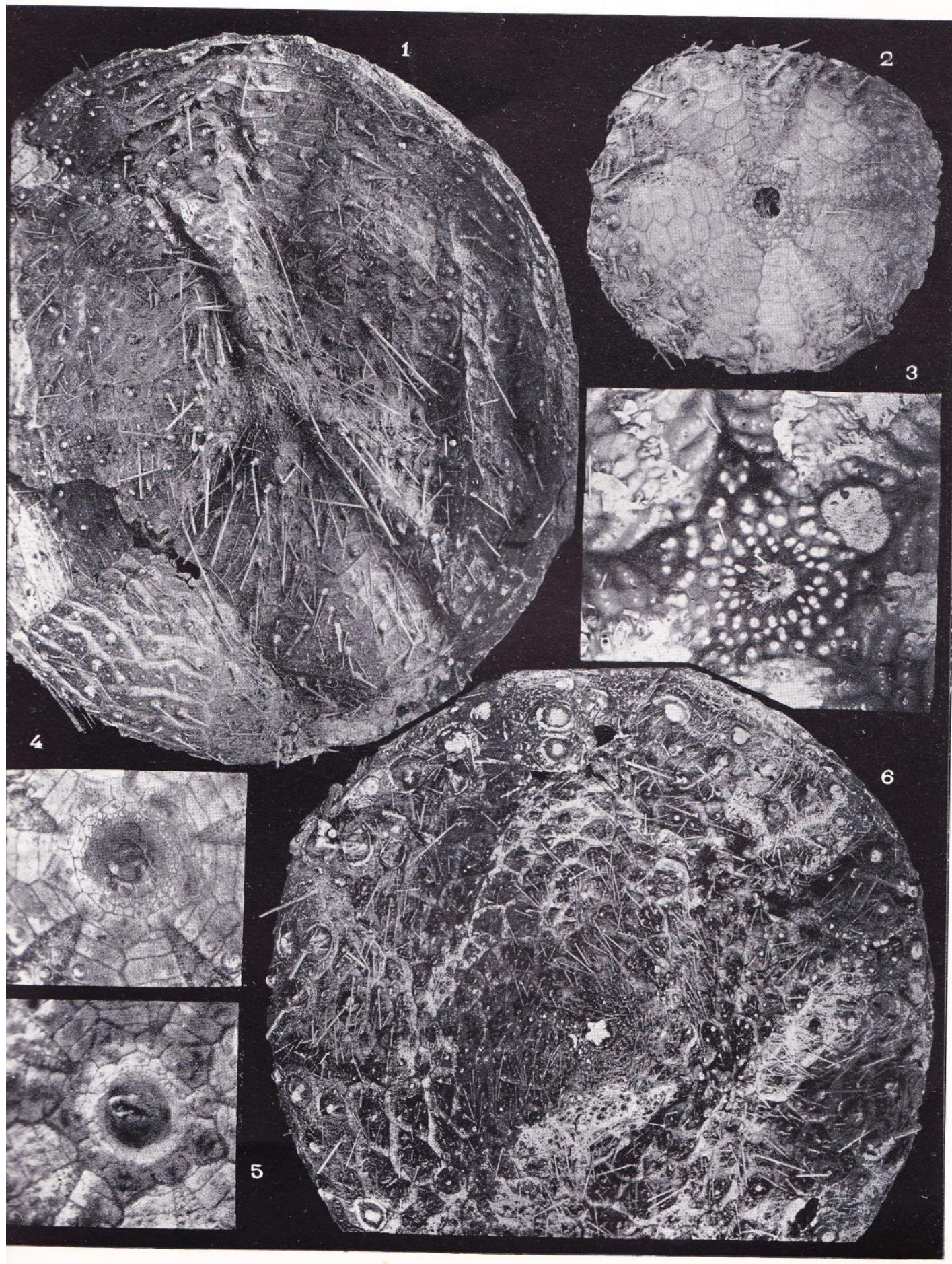

R. Kobler phot

Sté Lyonnaise de Photochromogravure

1 et 6 SPEROSOMA ARMATLM. 2 PHORMOSOMA INDICLY.

3 AR.EOSOMA CORIACELM Var. INDICUM. 4-5 CHOETODIADEMA GRANULATIM. 
Plate IX

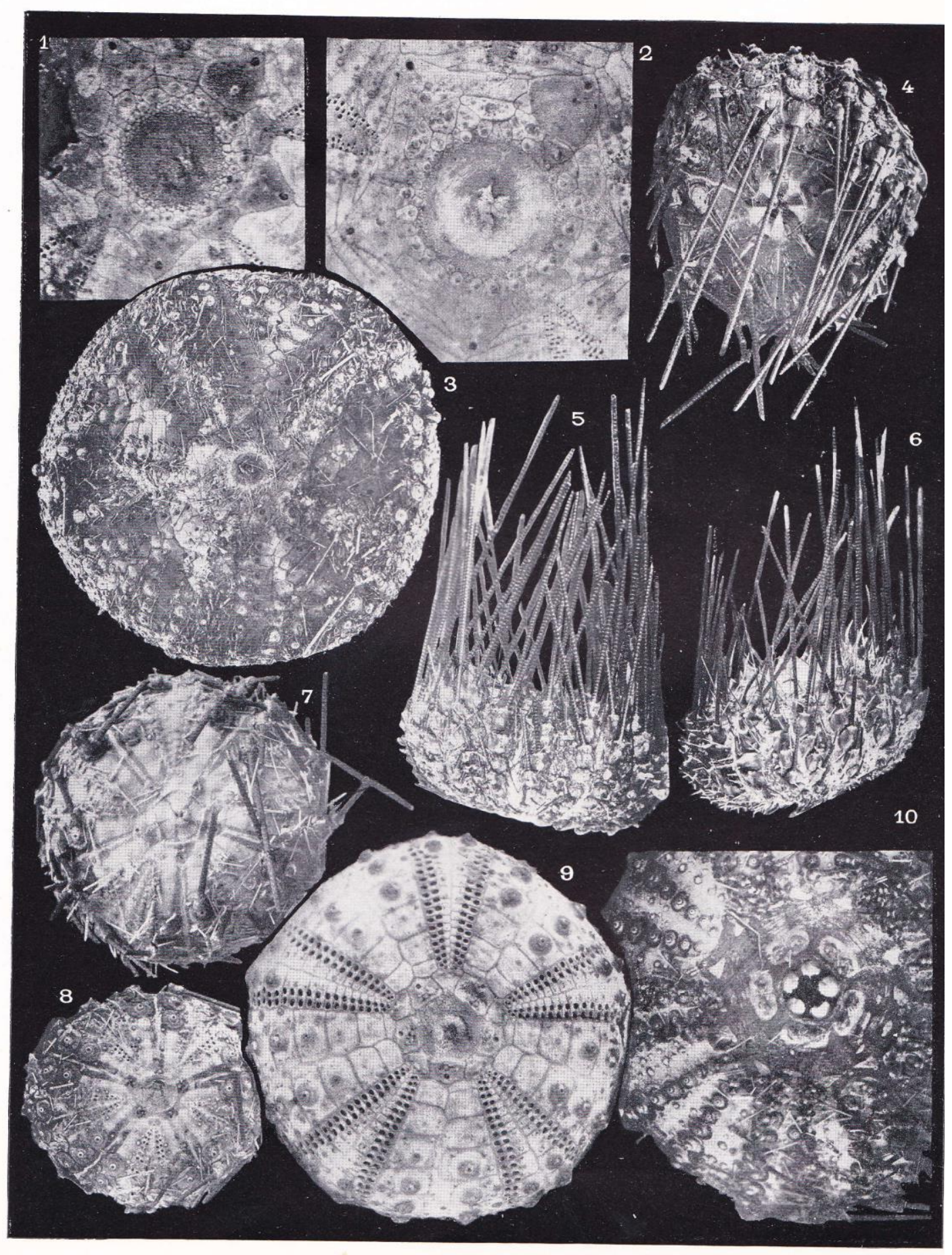

I. Kowler phot.

Sté Lyonnaise de Photochromograrure 
Plate $\mathrm{X}$

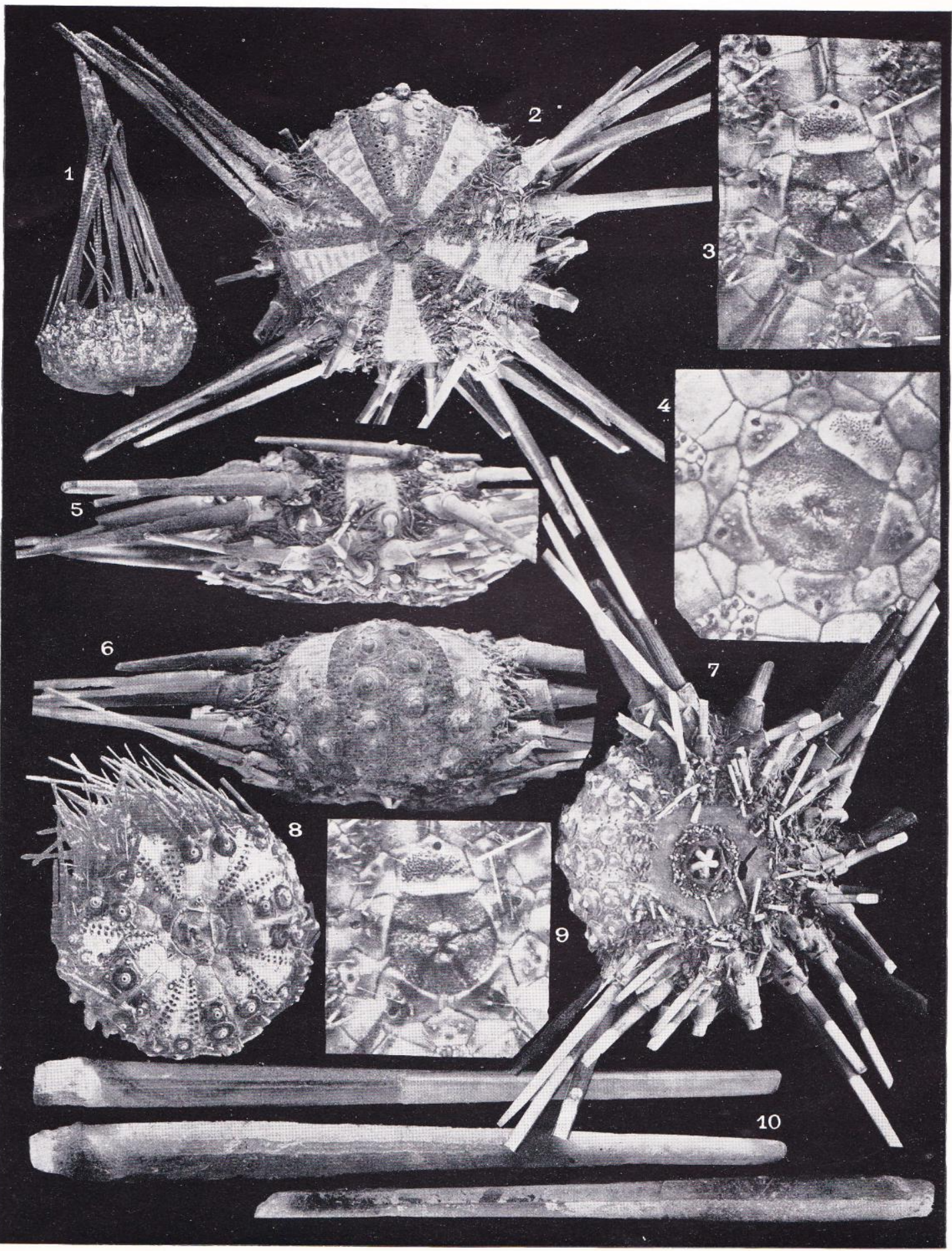

R. Kwhler plot.

Sté Lyonnaise de Photochromogravure 
Plate XI

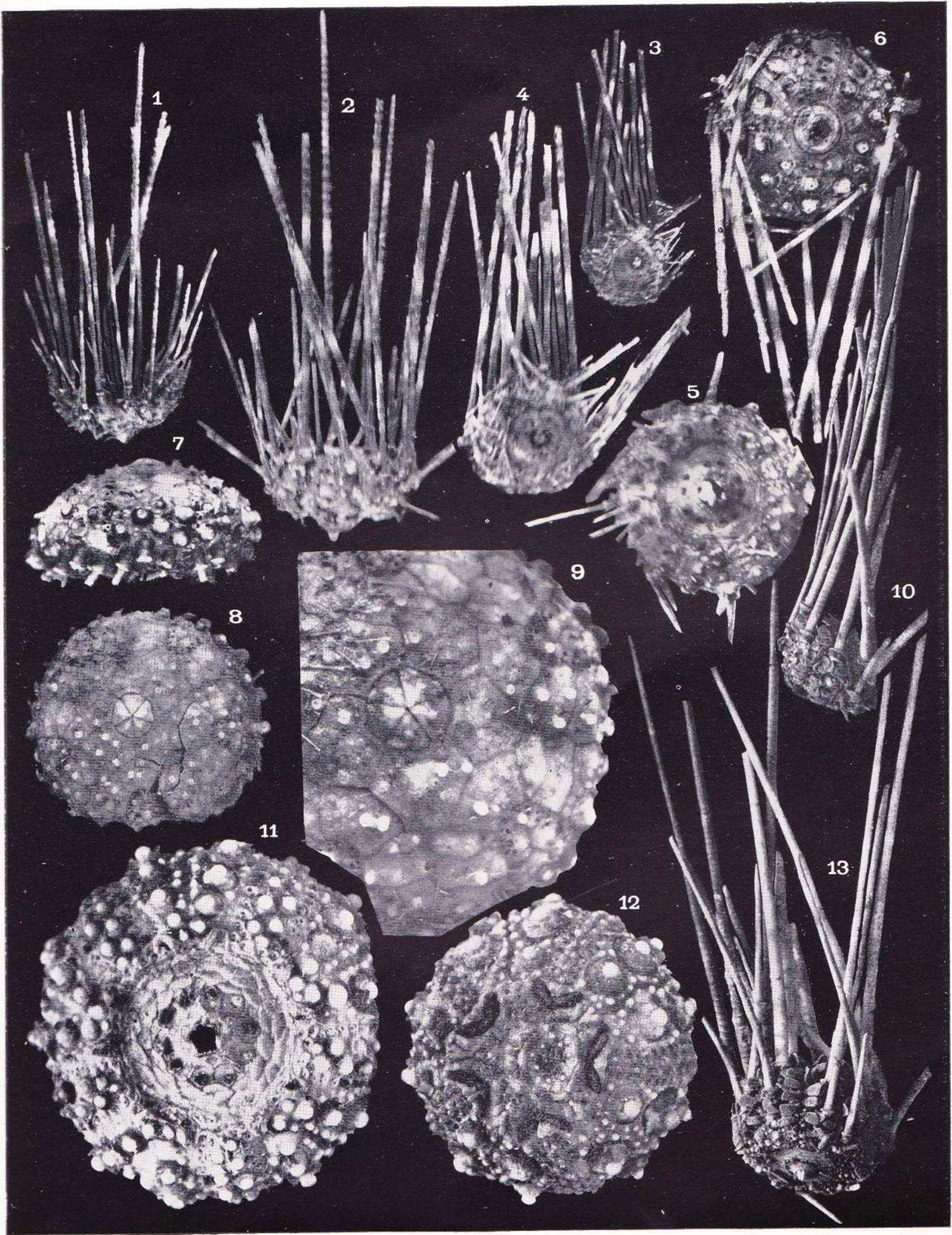


Plate XII

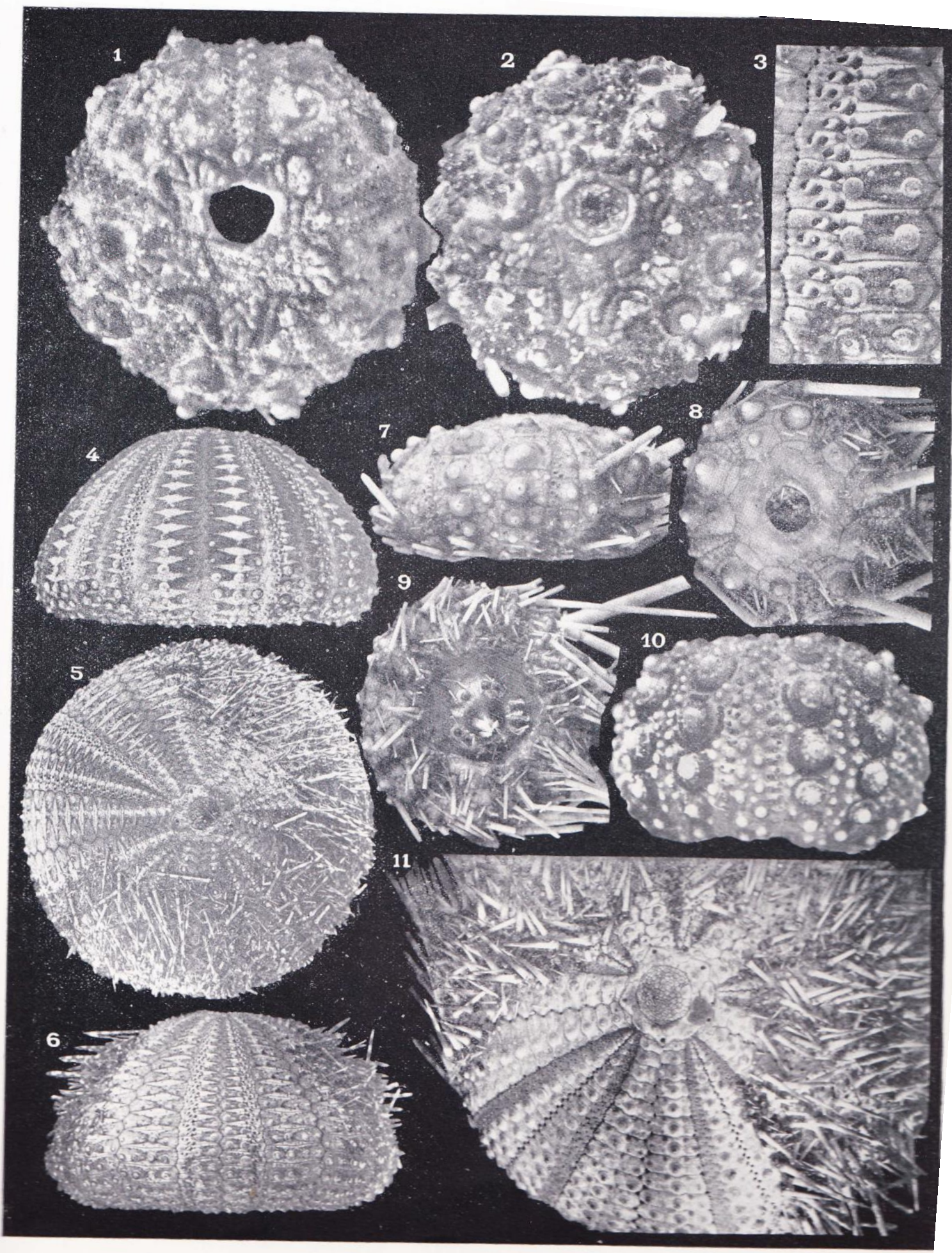



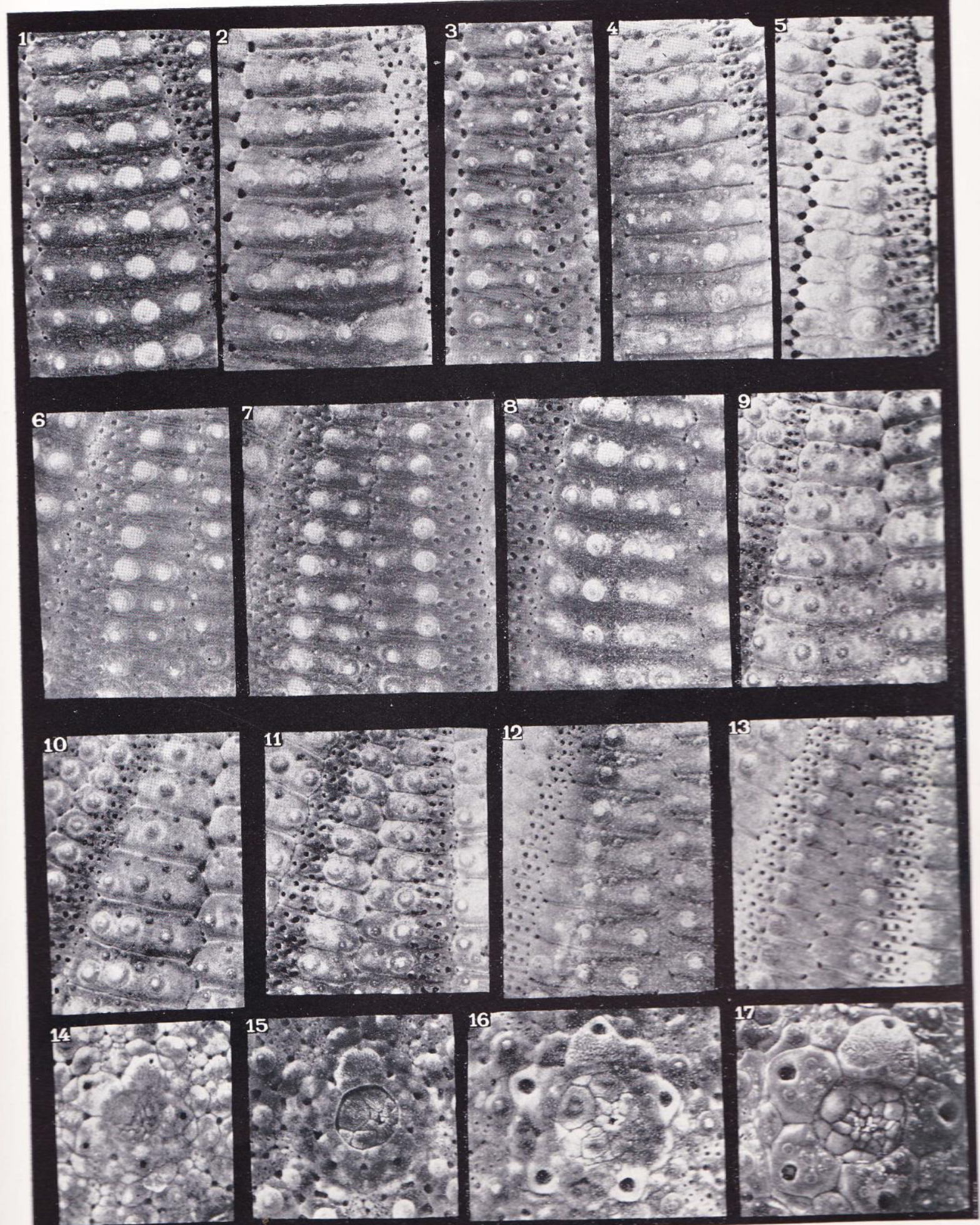


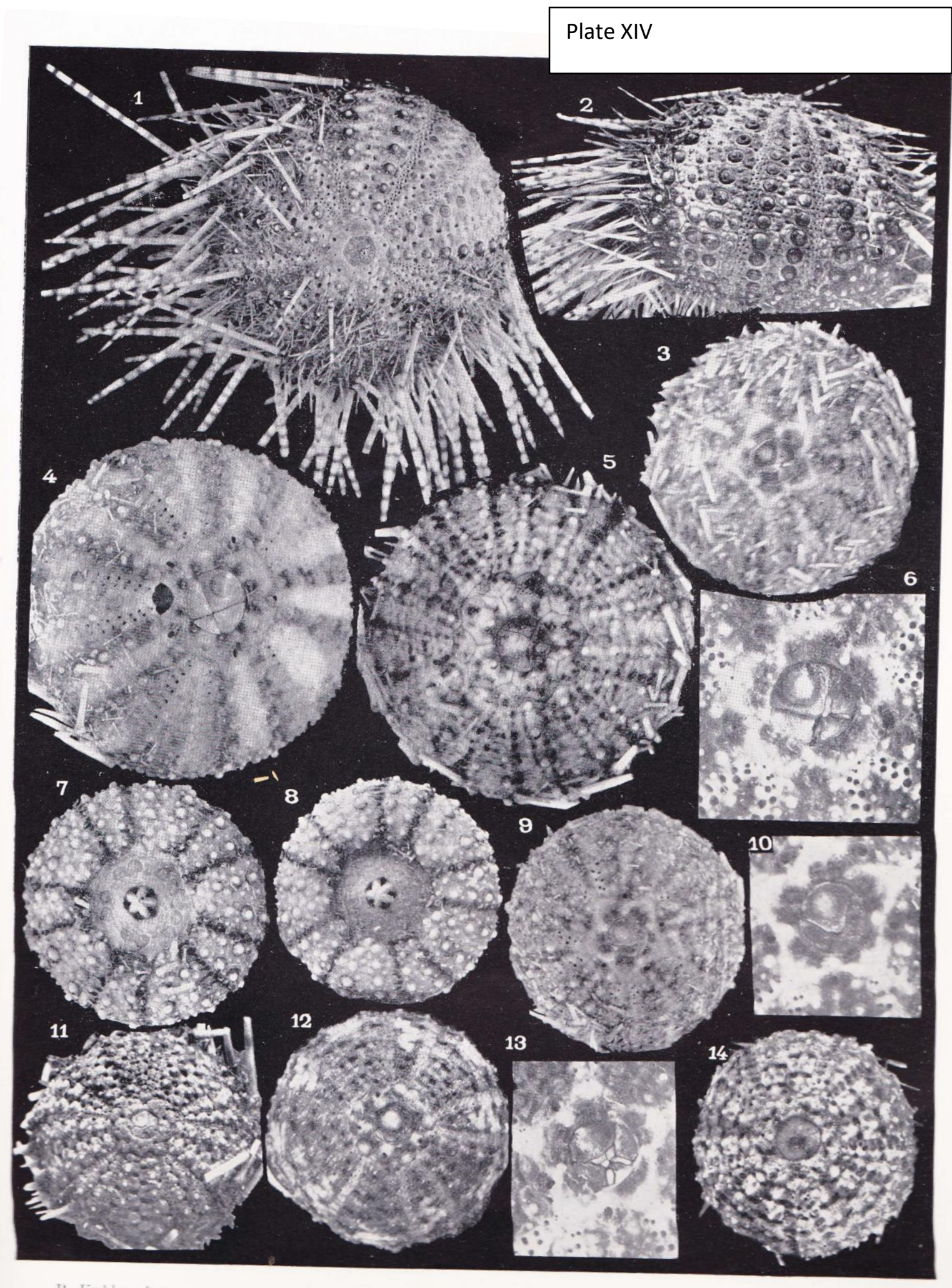

-2 TEMNOPLEURUS TORELMATICU S, 3-4, 6-10 et 13 TRIGONOCIDARIS VERGICOLOR.

5 TRIGONOCIDARIS ALBIDA. 11 ef 14 TEMNOTREMA GIAVENSE, 12 TEMNOTREMA SOH F 


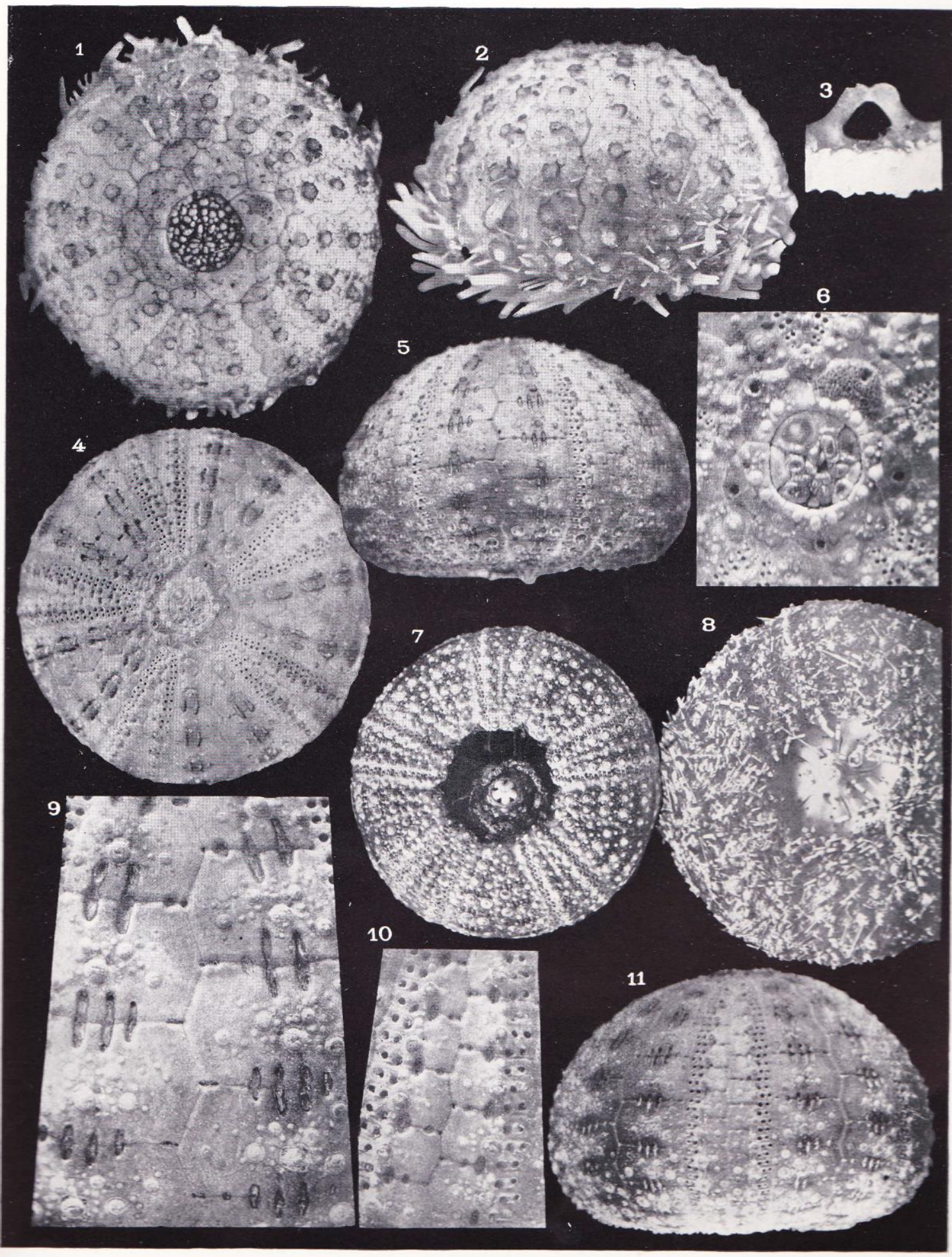




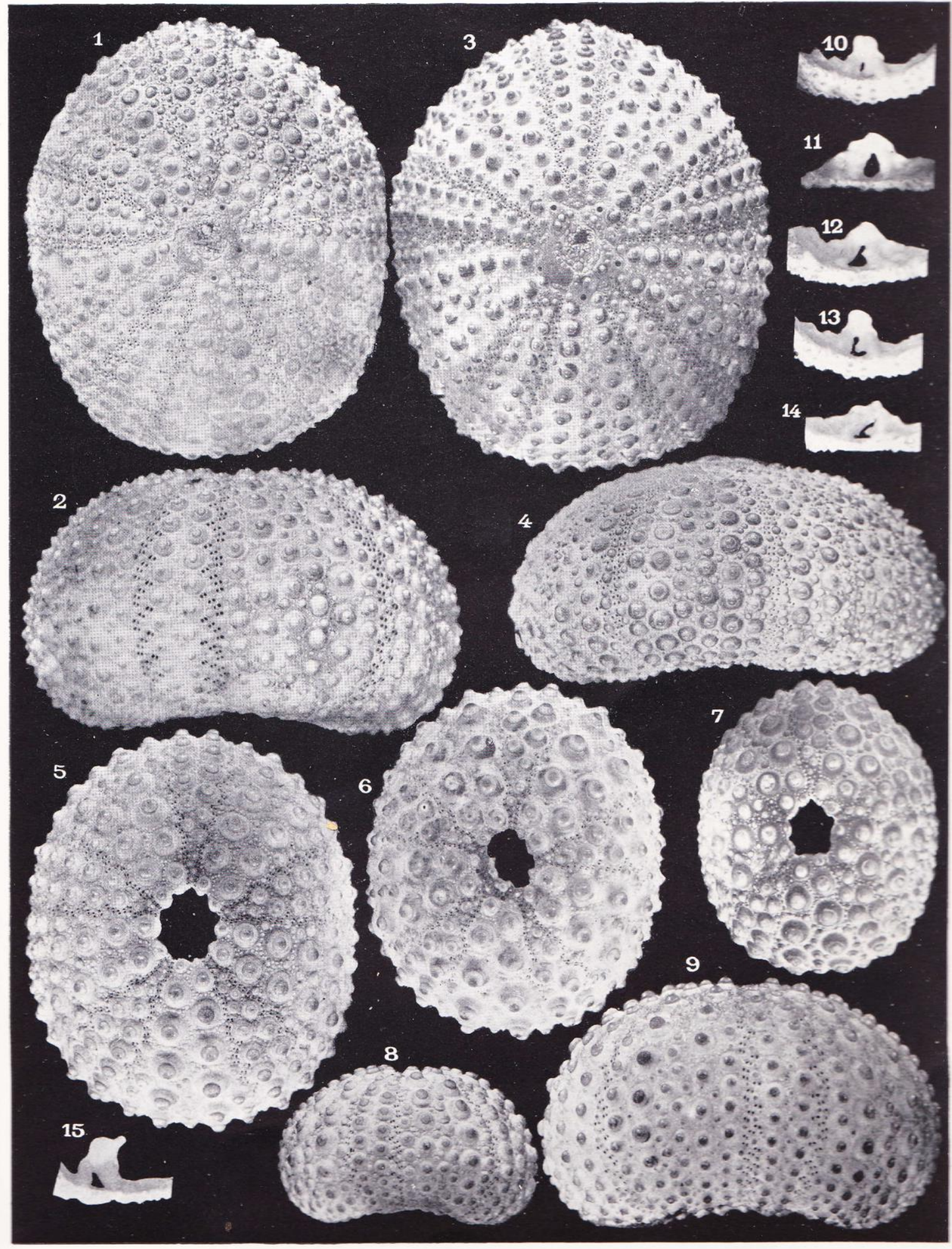




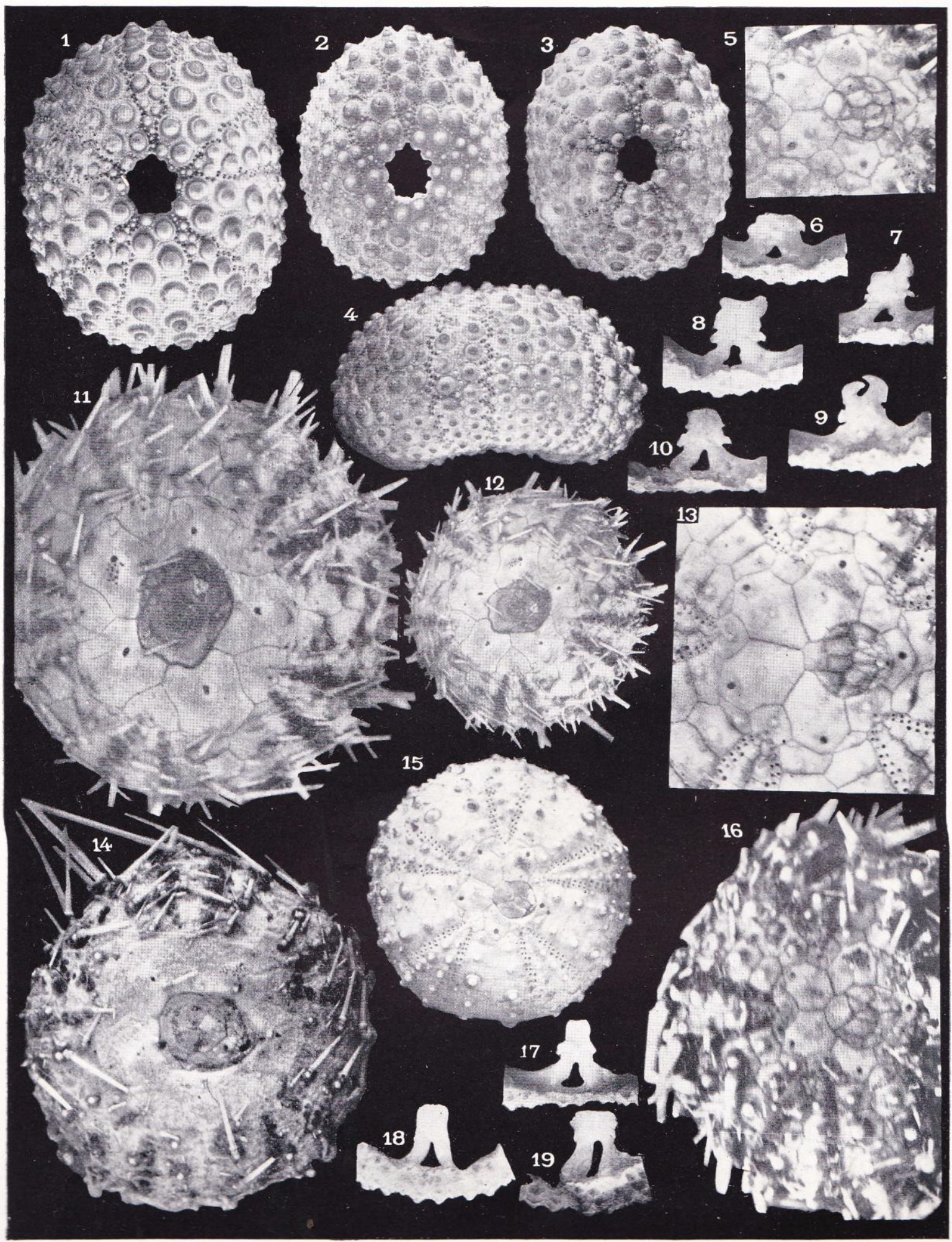




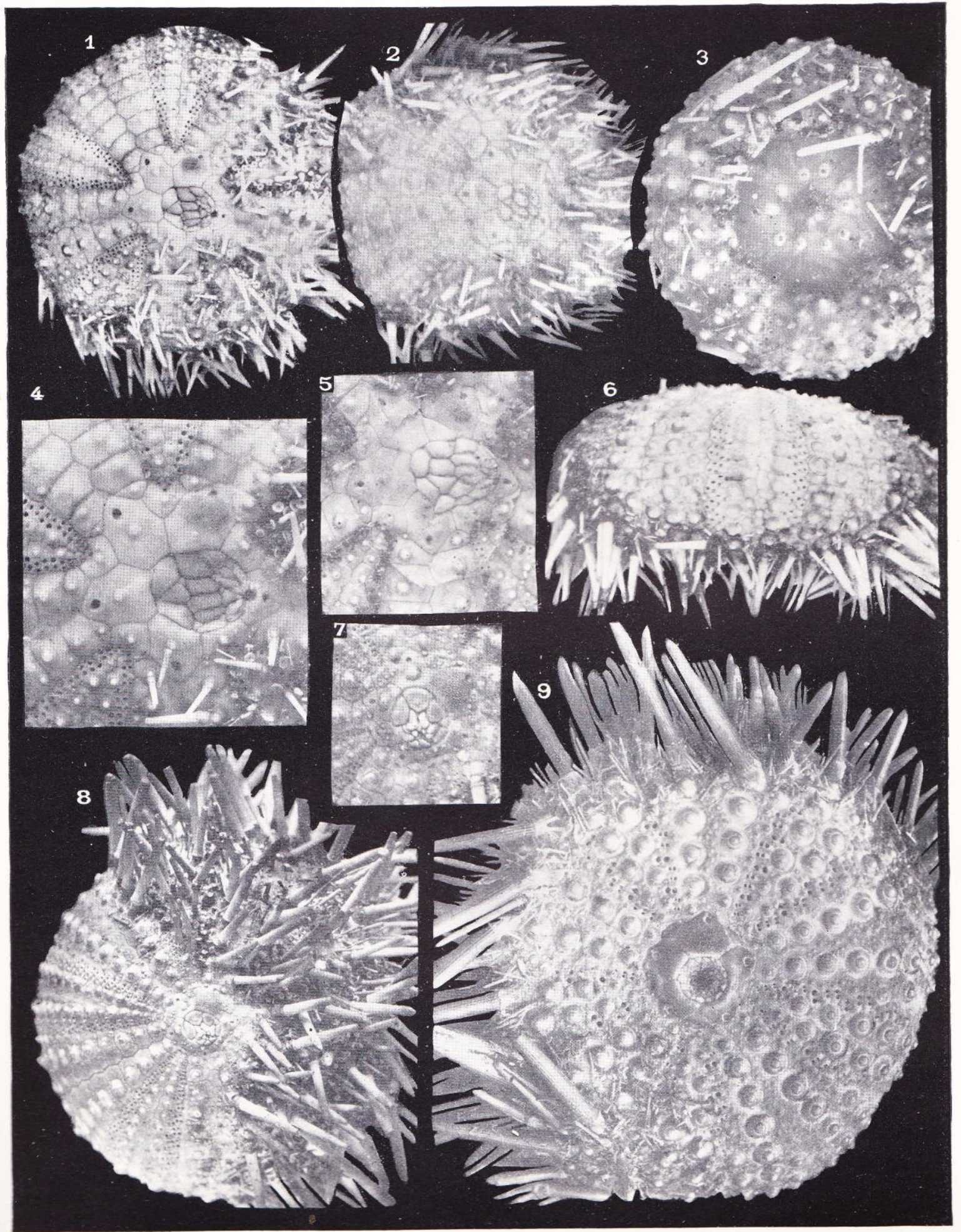




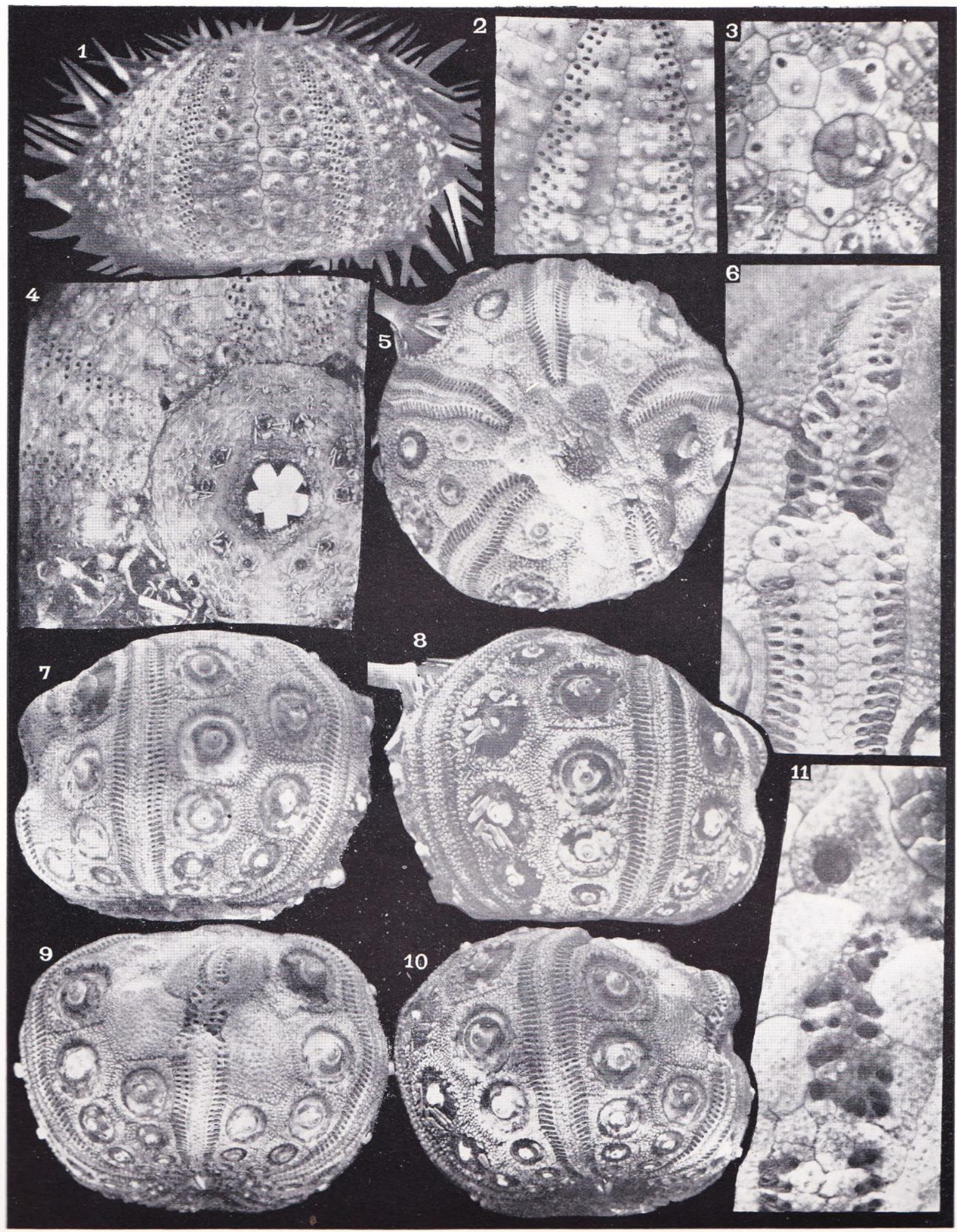


Plate XX

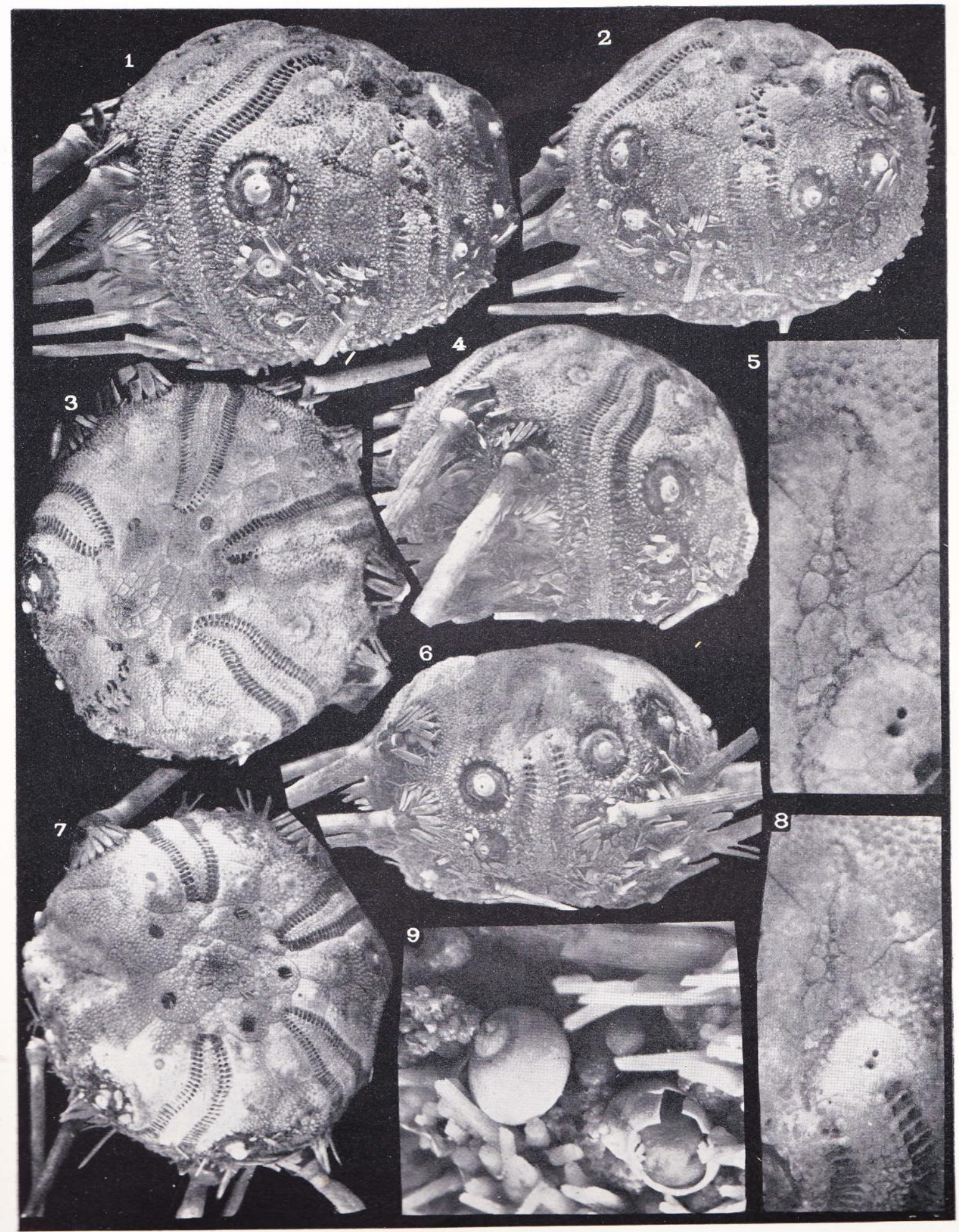

Ii. Kimbler phot. 


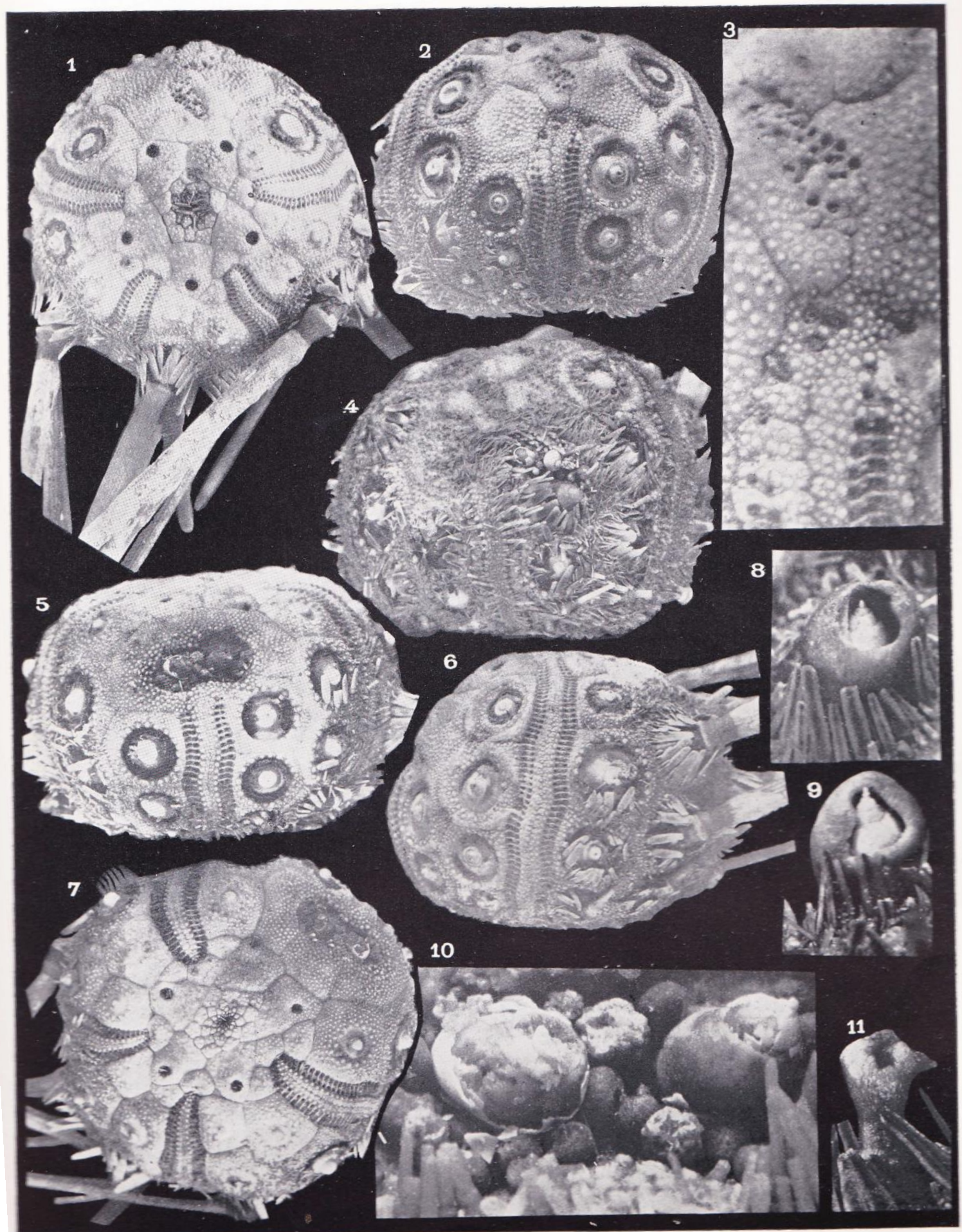




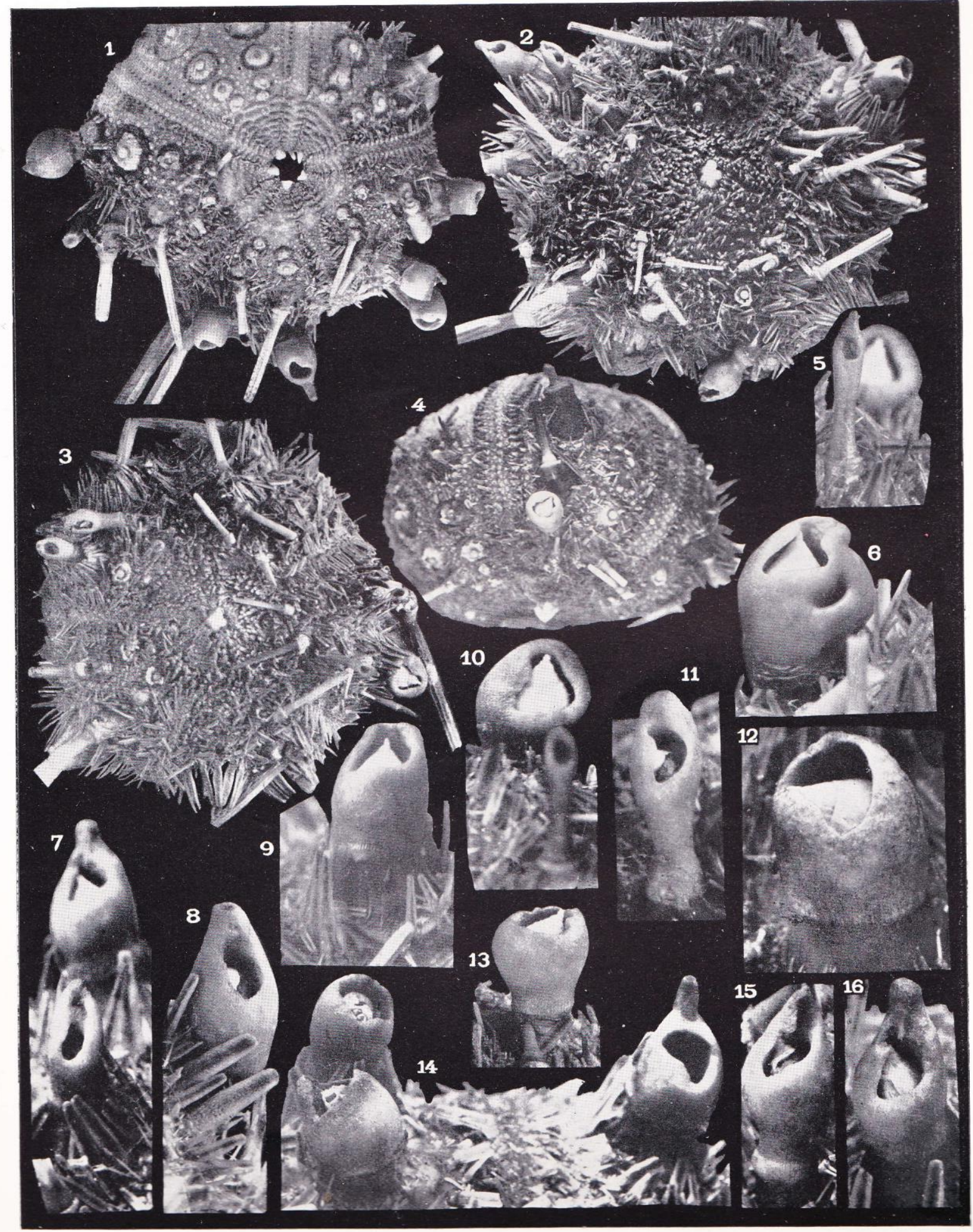




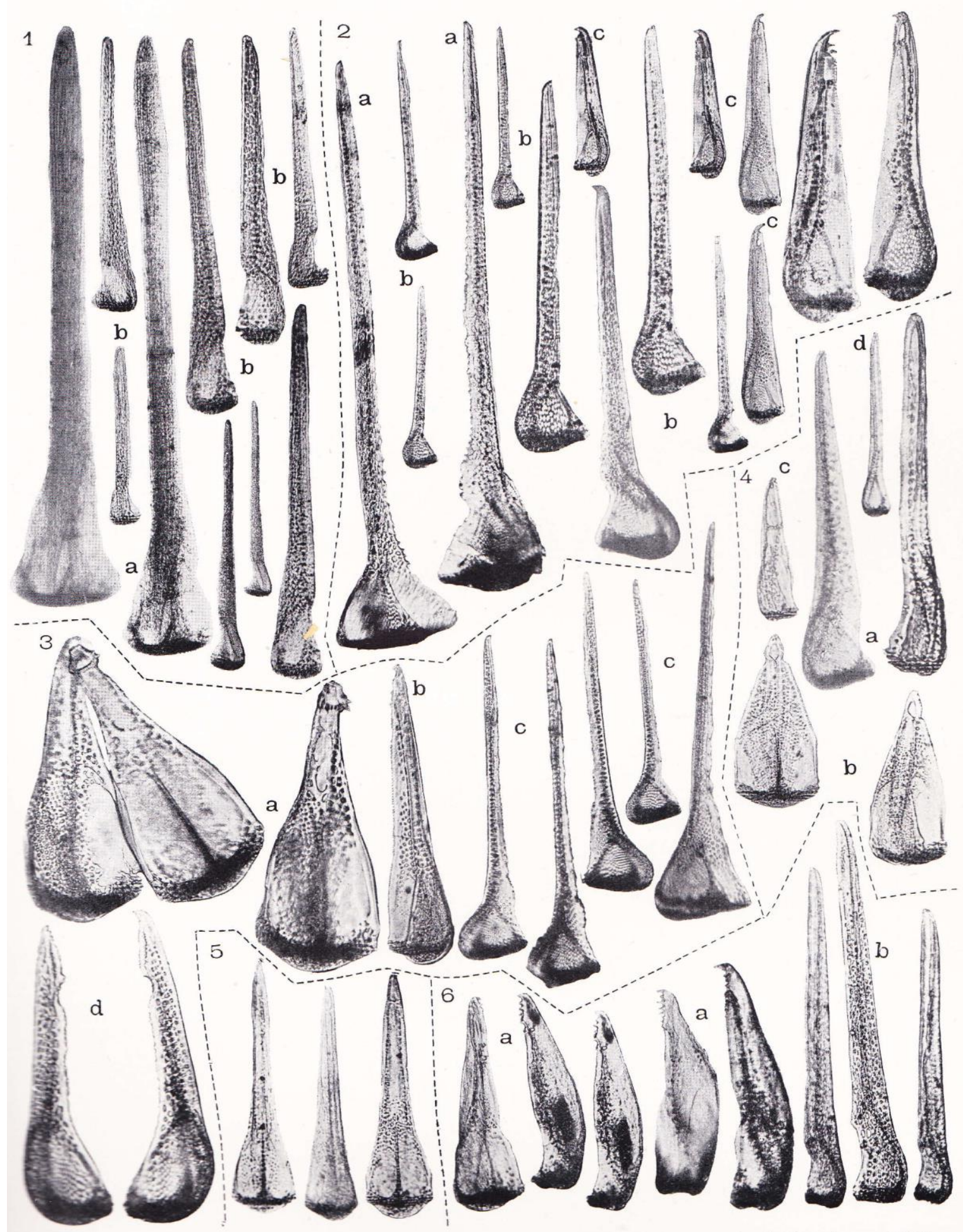

IX. Kraler phot. 


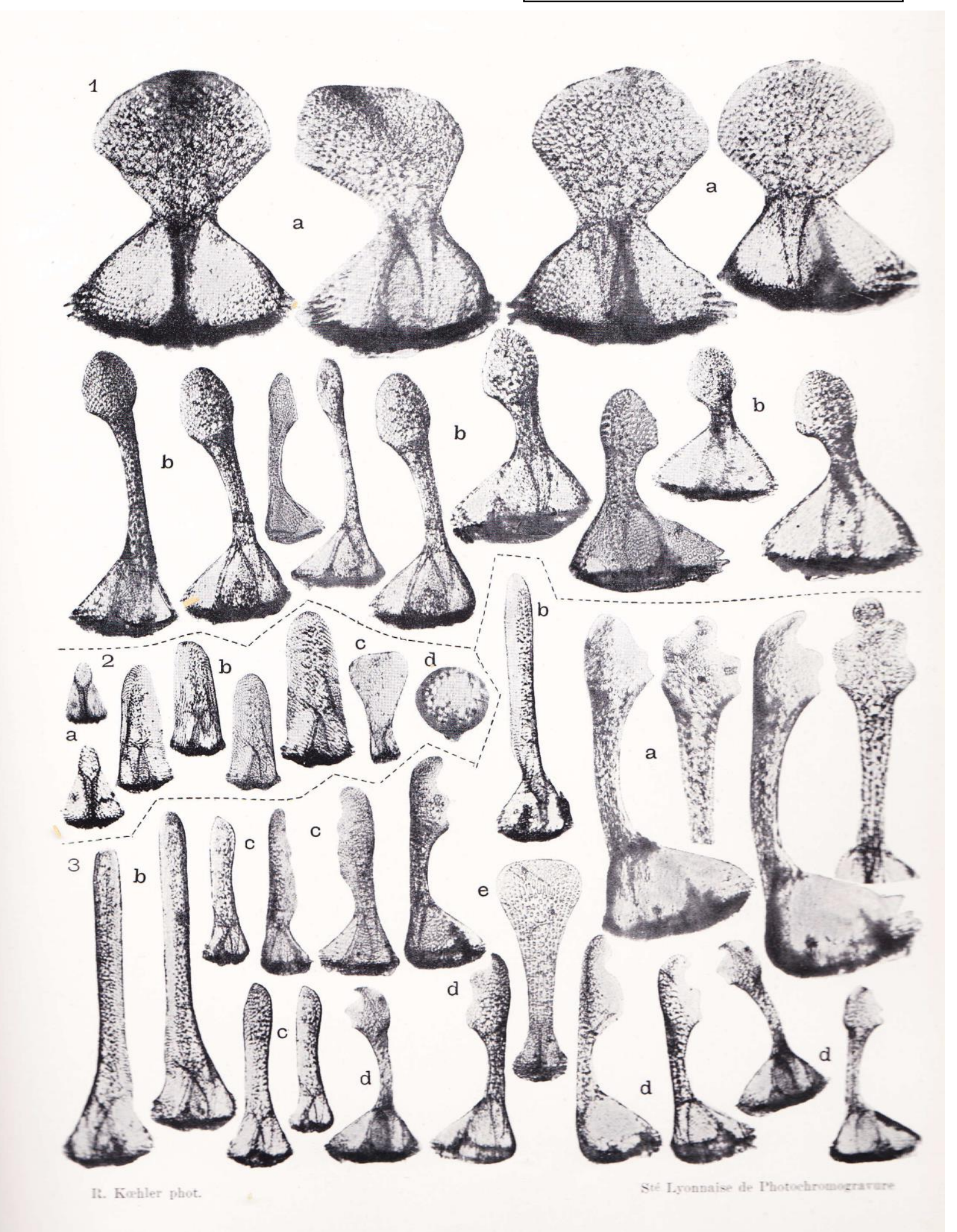




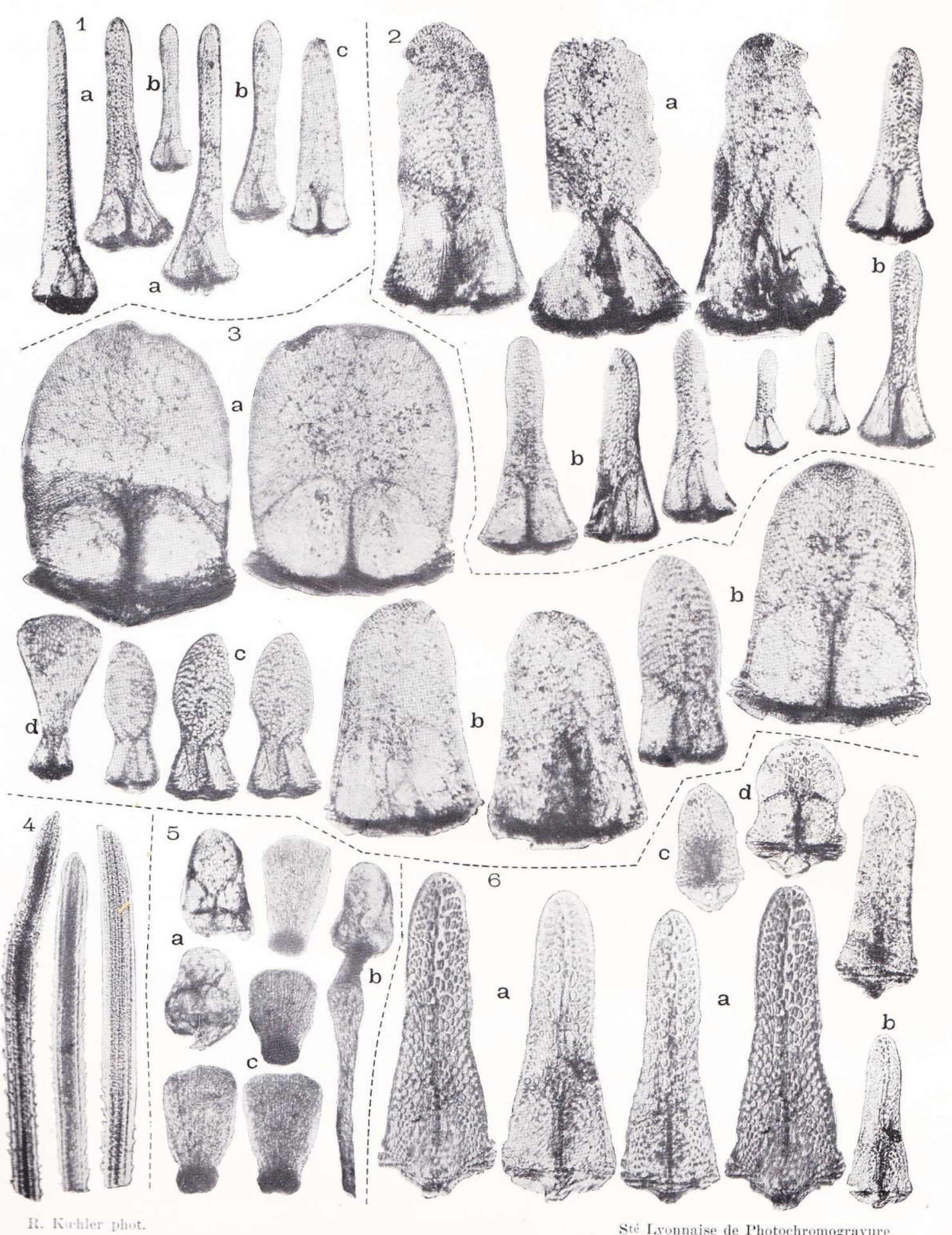

1 PHoRMOSOMA INDICUM. 2 SPEROSOMA BISERIATUM. 3 SPEROSOMA ARMATUM. a CHOETODIADEMA GRANULATUM.

5 SALENIA SCLLPTA. 6 COELOPLELRL'S VITTATUS. 


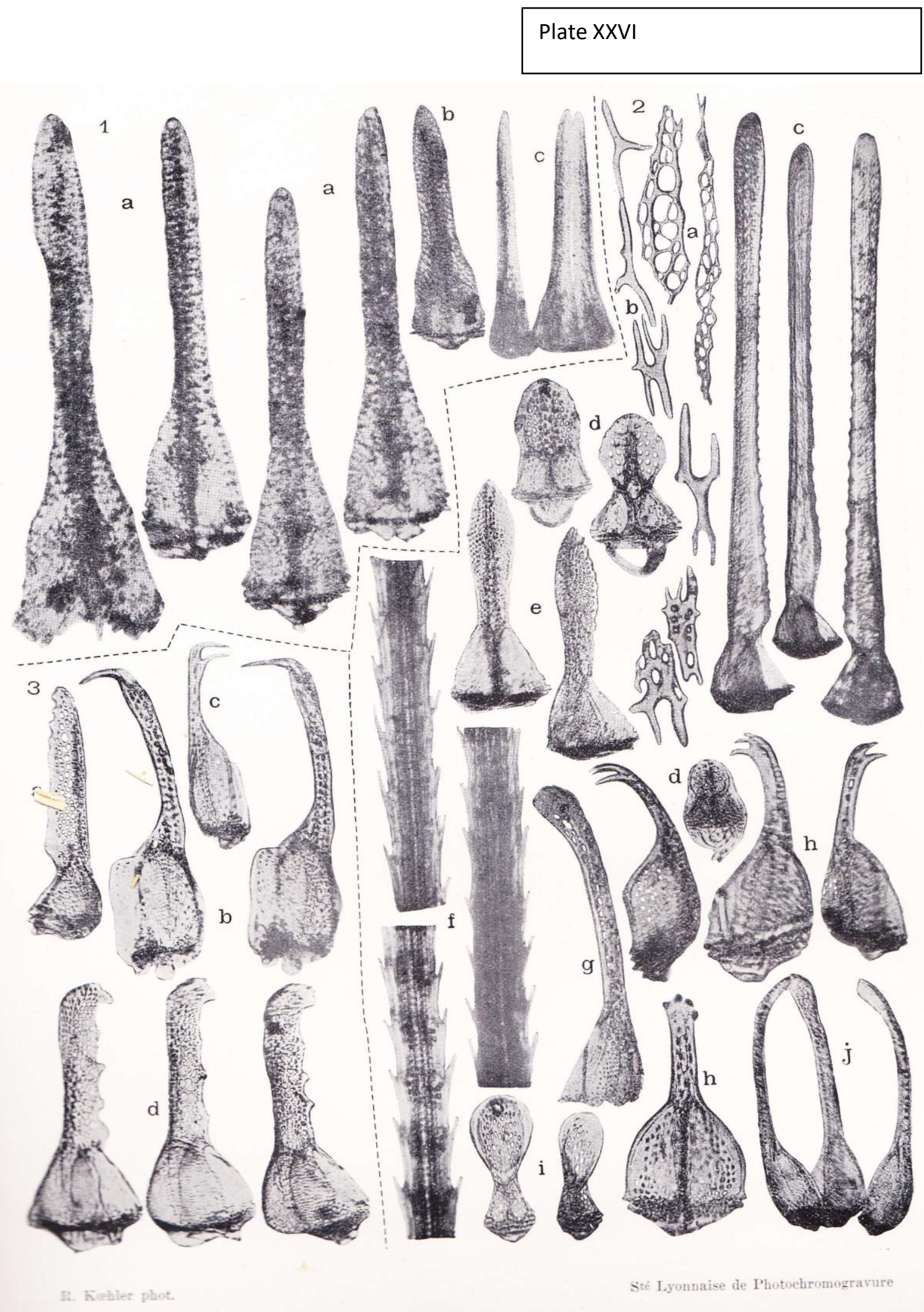

1 ovelopleurus VITTATUS. 2 CENTROSTEPHANuS NITIDUS. 3 SALMACIS ROSEO-VIRIDIS. 


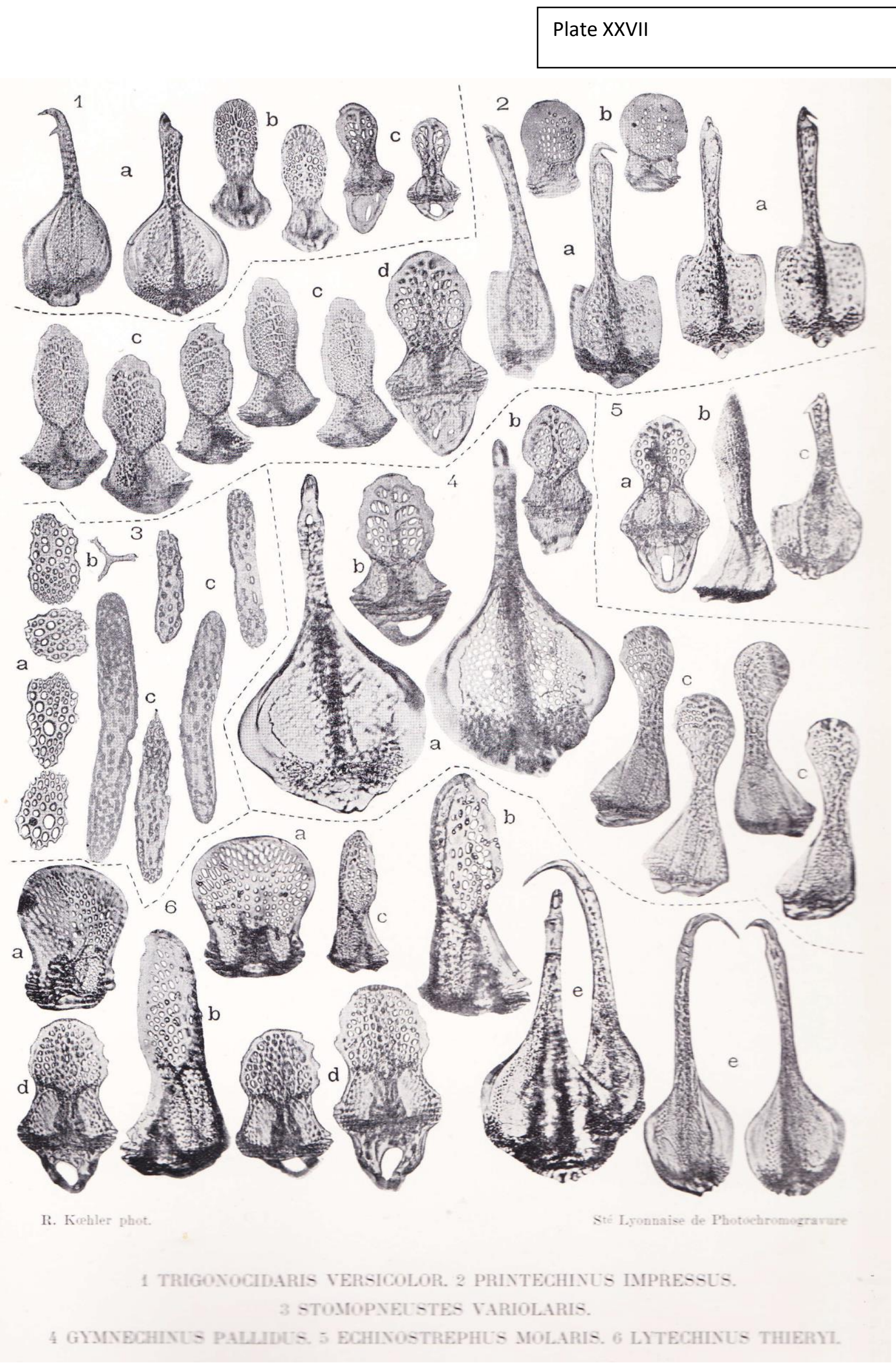


